\title{
Human Capital Mismatch in the Labour Market
}

Citation for published version (APA):

Somers, M. A. (2020). Human Capital Mismatch in the Labour Market. [Doctoral Thesis, Maastricht University]. https://doi.org/10.26481/dis.20200109ms

Document status and date:

Published: 01/01/2020

DOI:

10.26481/dis.20200109ms

Document Version:

Publisher's PDF, also known as Version of record

\section{Please check the document version of this publication:}

- A submitted manuscript is the version of the article upon submission and before peer-review. There can be important differences between the submitted version and the official published version of record.

People interested in the research are advised to contact the author for the final version of the publication, or visit the DOI to the publisher's website.

- The final author version and the galley proof are versions of the publication after peer review.

- The final published version features the final layout of the paper including the volume, issue and page numbers.

Link to publication

\footnotetext{
General rights rights.

- You may freely distribute the URL identifying the publication in the public portal. please follow below link for the End User Agreement:

www.umlib.nl/taverne-license

Take down policy

If you believe that this document breaches copyright please contact us at:

repository@maastrichtuniversity.nl

providing details and we will investigate your claim.
}

Copyright and moral rights for the publications made accessible in the public portal are retained by the authors and/or other copyright owners and it is a condition of accessing publications that users recognise and abide by the legal requirements associated with these

- Users may download and print one copy of any publication from the public portal for the purpose of private study or research.

- You may not further distribute the material or use it for any profit-making activity or commercial gain

If the publication is distributed under the terms of Article $25 \mathrm{fa}$ of the Dutch Copyright Act, indicated by the "Taverne" license above, 
Human Capital Mismatch in the Labour Market Melline A. Somers 
(C) Melline Somers, Maastricht 2020.

All rights reserved. No part of this publication may be reproduced, stored or transmitted in any form or by any means without the prior written permission of the author.

ISBN: 978-90-830451-0-8

Cover design: Raadhuis voor creatieve communicatie, Alkmaar

This book is no XIV of the TIER Research Series, a PhD thesis series published by TIER.

Financial support by Instituut Gak, Sectoral Plan 'Werk maken van Talent', the Amsterdam Economic Board, and 'House of Skills' is gratefully acknowledged. 


\title{
Human Capital Mismatch in the Labour Market
}

\author{
Dissertation \\ to obtain the degree of Doctor \\ at Maastricht University, \\ on the authority of the Rector Magnificus, Prof. Dr. Rianne M. Letschert \\ in accordance with the decision of the Board of Deans, \\ to be defended in public on \\ Thursday 9 January 2020, \\ at 14:00 hours \\ by \\ Melline Annaliese Somers
}




\section{Promotors}

Prof. dr. Wim Groot

Prof. dr. Henriëtte Maassen van den Brink (University of Amsterdam)

\section{Co-promotor}

Dr. Sofie J. Cabus (KU Leuven)

\section{Doctoral thesis committee}

Prof. dr. Bart Golsteyn (Chair)

Prof. dr. Franziska Gassmann

Prof. dr. Eric Hanushek (Stanford University)

Prof. dr. Joop Hartog (University of Amsterdam)

Prof. dr. Rolf van der Velden 


\section{Dankwoord}

Of ik van jongs af aan een wetenschappelijke loopbaan ambieer betwijfel ik. Ik herinner mij nog goed dat mijn basisschoolleraar mij vroeg wat ik later wilde worden. Ik vertelde hem dat ik het wel zag zitten om bioloog te worden waarop zijn reactie was: "dan word ik zeker 105 jaar oud". Uiteindelijk ben ik na mijn middelbare school bedrijfseconomie gaan studeren omdat ik in de veronderstelling was dat deze opleiding tot een goed gevulde bankrekening zou leiden. Omdat ik wel gecharmeerd was van het pittoreske Maastricht, en de Universiteit van Tilburg net niet ver genoeg verwijderd was van mijn ouderlijke huis, besloot ik om in 2008 te starten aan de opleiding aan de Universiteit Maastricht. Dat ik uiteindelijk aan dezelfde universiteit aan een promotietraject zou starten was lange tijd niet evident. Er zijn meerdere mensen die mij in de afgelopen jaren hebben geënthousiasmeerd voor de wetenschap en geholpen hebben bij de totstandkoming van dit proefschrift. Een aantal van hen wil ik hier in het bijzonder bedanken.

Allereerst wil ik mijn promotoren Prof. Groot en Prof. Maassen van den Brink bedanken. Wim en Henriëtte, ik ben ontzettend dankbaar voor het feit dat jullie mij de kans hebben geboden om als $\mathrm{PhD}$ kandidaat bij TIER aan de slag te mogen gaan en voor het vertrouwen dat jullie altijd in mij hebben gehad. Jullie begeleiding heeft een grote rol gespeeld in het realiseren van dit proefschrift. Bedankt voor alle ruimte die jullie mij hebben gegeven voor mijn persoonlijke ontwikkeling op zowel wetenschappelijk als nietwetenschappelijk vlak.

Dr. Sofie Cabus, co-promotor, bedankt voor al je steun, enthousiasme, kennis en de prettige samenwerking. Ik heb ontzettend veel van je geleerd, voornamelijk op methodologisch vlak. Je was altijd benaderbaar en ik heb genoten van al onze gesprekken. Je pakt altijd door en dit heeft ervoor gezorgd dat we samen een aantal mooie wetenschappelijke bijdragen hebben kunnen leveren tijdens mijn promotietraject.

I would like to thank the members of my reading committee, Prof. Bart Golsteyn, Prof. Franziska Gassmann, Prof. Eric Hanushek, Prof. Joop Hartog and Prof. Rolf van der Velden for their time to evaluate this thesis and for their valuable comments.

Mijn paranimfen, Mélanie en Jolien. Lieve Mélanie, ik had me geen betere kamergenoot voor kunnen stellen tijdens mijn promotietraject. Je bent een onwijze steun voor mij geweest in de afgelopen jaren, zowel op werk als privé vlak. Er zijn maar weinig mensen zoals jij en ik ben erg dankbaar dat je zo een goede vriendin bent geworden. Lieve Jolien, bedankt dat je al vele jaren een fantastische vriendin voor me bent. Je hebt mij in alle mogelijk situaties gesteund en zag altijd iets positiefs in mijn keuzes. Ik ben ontzettend blij dat jullie mijn paranimfen willen zijn!

Mijn dank gaat ook uit naar collega's bij TIER die hebben bijgedragen aan een ontzettend leerzame en fijne tijd. Carla Lenssen en Astrid, bedankt voor al jullie werk-gerelateerde steun en gezellige momenten die ik met jullie bij TIER heb mogen delen! Hélène, ik keek 
altijd uit naar de dagen dat je bij mij op de kamer zat. Bedankt voor al je positiviteit en goede gesprekken die we hebben gehad. Carla Haelermans, ik weet nog goed dat je mij enthousiast welkom kwam heten op mijn eerste werkdag. Ik waardeer dat je altijd langs kwam voor een praatje en hecht veel waarde aan alle adviezen die je mij hebt gegeven. Melvin, ik vond het altijd gezellig om bij je op kantoor te zitten als ik in Amsterdam was. Ondanks dat je wat ver verwijderd was van het Maastrichtse TIER team kon ik altijd bij je terecht met mijn vragen. Ook de andere TIER collega's, François, Iryna, Eline, Bram, Joris, Kristof, Inne, Pauline, bedankt voor de leuke tijd op de Kapoenstraat 2!

Didier, ik heb mijn masterscriptie met onwijs veel plezier bij jou geschreven. Ik heb in die periode ontzettend veel van je geleerd en ik waardeer de tijd die je altijd nam om ons artikel naar een hoger niveau te brengen. Je hebt mijn interesse voor de wetenschap aangewakkerd en ik ben blij je nu mijn collega te mogen noemen.

Mijn lieve vriendinnen, Ireen, Anke, Sanne, Annely, Amy en Maud. Ondanks het feit dat jullie het mooie Maastricht lange tijd geleden hebben verlaten, heb ik het idee dat we in de afgelopen jaren eigenlijk meer naar elkaar zijn toe gegroeid. En ondanks al onze verschillen zijn jullie er zowel in moeilijke als in mooie tijden voor mij geweest. Dank hiervoor! Oh, en voor ik het vergeet, bedankt voor het verdragen van al mijn monologen over onderzoek in onze WhatsApp-groep. Lynn, bedankt dat je sinds het $2^{\mathrm{e}}$ blok van onze opleiding een goede vriendin voor me bent geweest. Vriendinnen van het Augustinianum, Fleur, Marjolein, Iris en ook Jolien, bedankt dat we altijd vriendinnen zijn gebleven en voor de nodige afleiding tijdens onze ontspannen weekendjes weg. Iris, ik vind het ontzettend leuk dat je tijdens je banenwissel een tijdje ons team in Amsterdam hebt willen versterken! Bedankt dat je mij bij het schrijven van het een-na-laatste hoofdstuk van mijn proefschrift hebt kunnen motiveren om een aantal belangrijke knopen door te hakken. Fabrizio, grazie per essere un grande amico negli ultimi anni e per tutte le birre che abbiamo bevuto insieme.

Vrienden van de Nationale DenkTank, tijdens mijn promotietraject heb ik de kans gekregen om een aantal maanden met jullie een bijdrage te leveren aan het beroepsonderwijs van de toekomst. Ik heb een mooie tijd met jullie doorgemaakt en veel van jullie geleerd. Ik heb veel bewondering voor alles wat jullie bereikt hebben in de wereld van het onderwijs.

Graag wil ik ook een aantal nieuwe collega's en vrienden bedanken. Lidwien, toen ik op mijn eerste werkdag mijn kantoor introk bleek jij mijn buurvrouw te zijn op de gang. Wat ben ik onwijs blij dat ik jou in de afgelopen maanden beter heb mogen leren kennen. Je bent een grote steun geweest in de afgelopen maanden en ik vind het jammer dat je Maastricht hebt verlaten! Sanne, ik vind het heel leuk dat jij mijn kamergenoot bent (en nee, dat is niet sarcastisch). Ik kan ontzettend met je lachen en wil je graag bedanken voor je steun in de afrondende fase van het schrijven van dit proefschrift. Mijn nieuwe collega's van het ROA, en in het bijzonder Rolf, Katarina, Per, Mark, Marie-Christine, 
Raymond, Maaike, Annemarie, bedankt dat jullie mij de mogelijkheid bieden om samen aan mooie projecten te werken. Ik kijk uit naar onze verdere samenwerking!

Lynne, thank you for checking my thesis on English language!

Lieve Jeroen, dankjewel dat je er voor me was bij de laatste maar zeker niet onbelangrijke stappen!

Als laatste wil ik mijn ouders bedanken. Lieve papa en mama, bedankt voor al jullie liefde, onvoorwaardelijke steun en voor het hebben van weinig verwachtingen. Zonder jullie harde werken zou ik dit niet hebben bereikt! 


\section{Table of Contents}

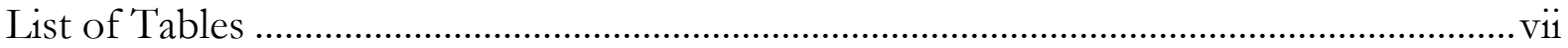

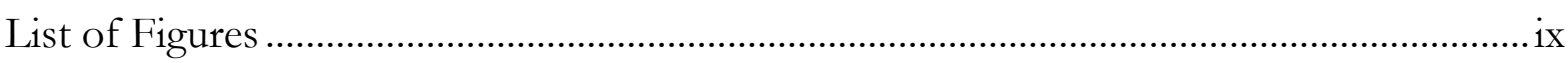

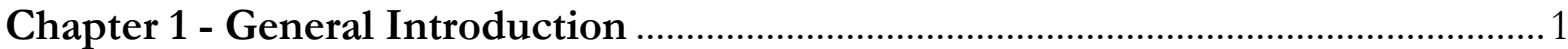

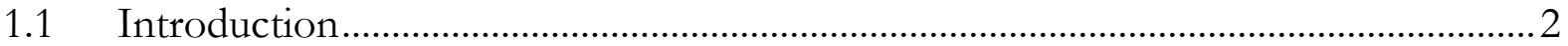

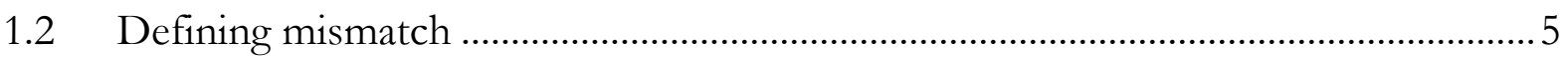

1.2.1 Measuring mismatch at the worker level .......................................................... 6

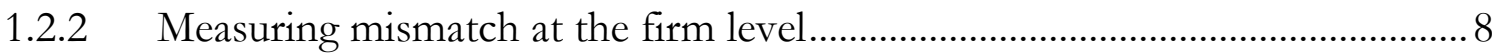

1.2.3 Macro-economic indicator of mismatch ....................................................... 8

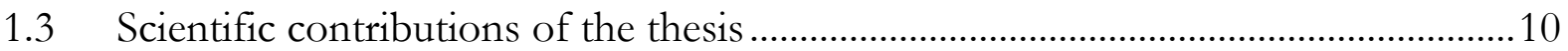

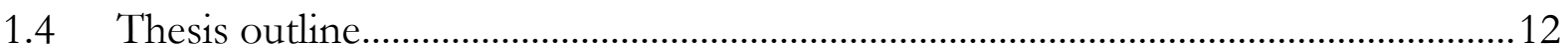

Part 1 - Incidence and Determinants of Mismatch between Human Capital and Labour Demand

Chapter 2 - Horizontal Mismatch between Employment and Field of Education: Evidence from a Systematic Literature Review ...........................................................19

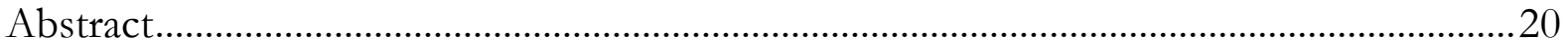

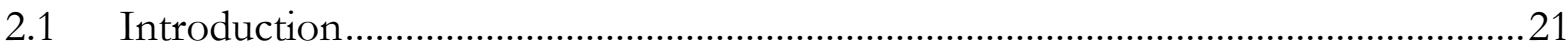

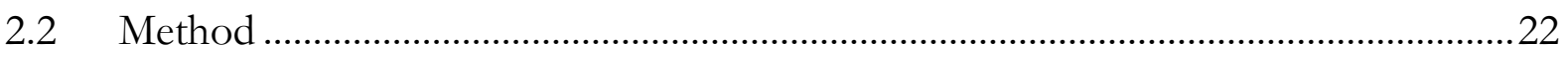

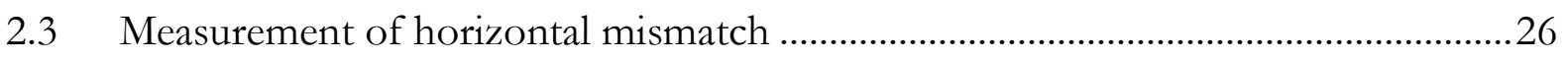

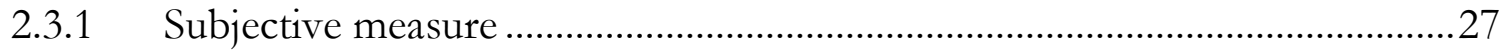

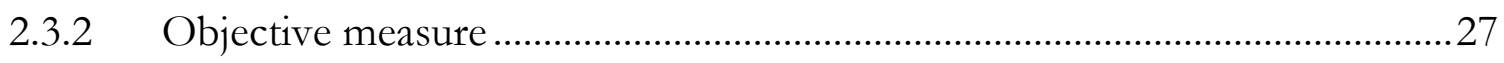

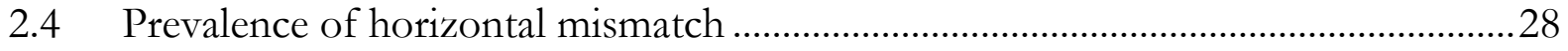

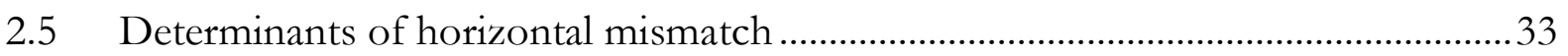

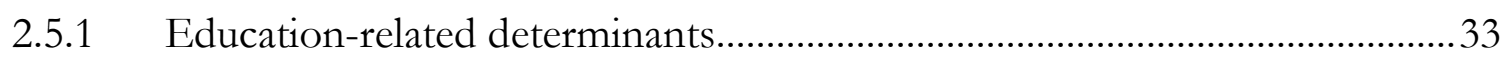

2.5.2 Labour market-related determinants................................................................. 38

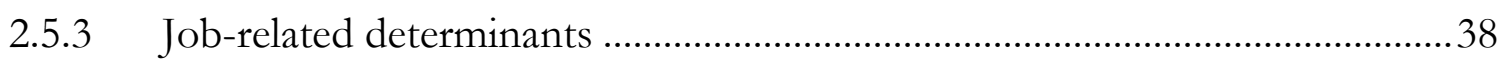

2.5.4 Determinants related to individual characteristics ..........................................43

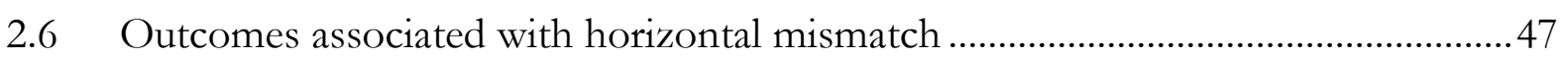

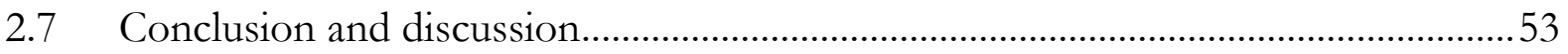

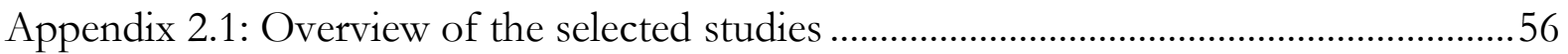

Appendix 2.2: Strategy used in computerized databases search ........................................63

Chapter 3 - Mismatch Between Education and the Labour Market in the Netherlands: Is it a Reality or a Myth? The Employers' Perspective .........................65

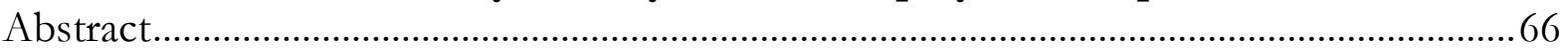

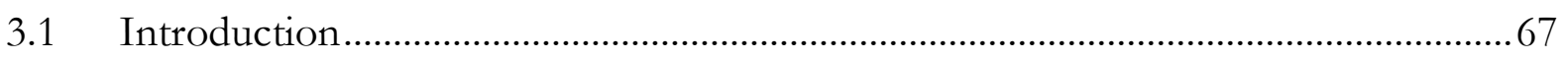

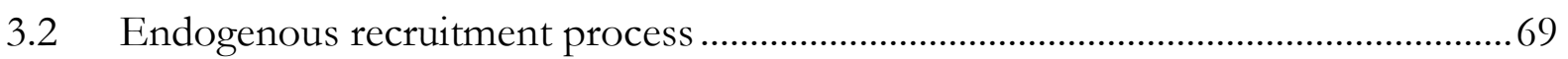

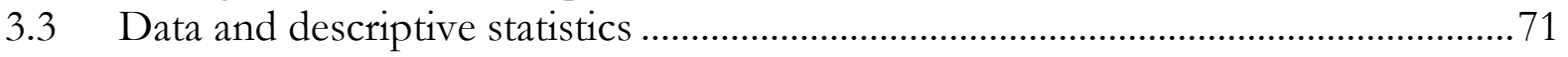

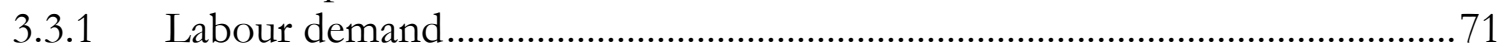

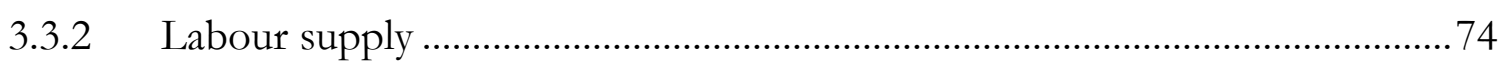

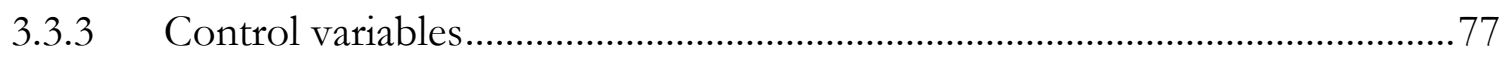

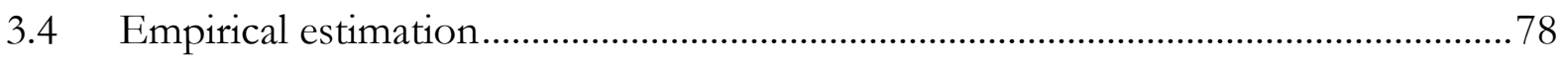




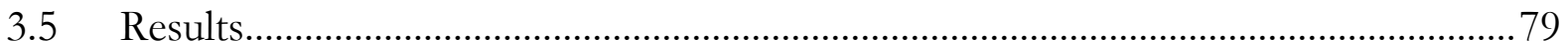

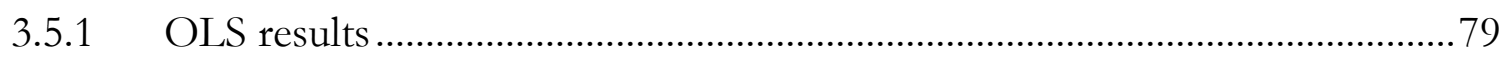

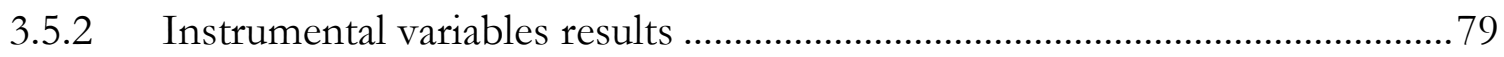

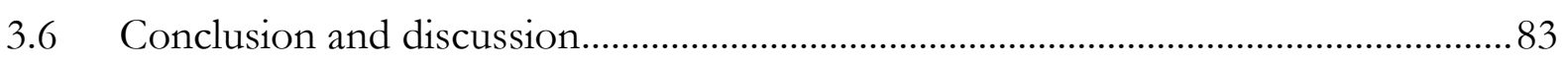

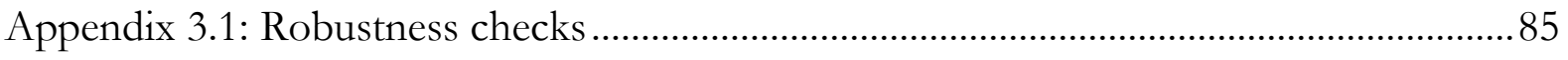

\section{Part 2 - Preventing Mismatch Between Human Capital and Labour Demand}

Chapter 4 - The Effect of a Five-Day Intervention on STEM Enrolment in Vocational Education and Training - Evidence from the Netherlands .....................89

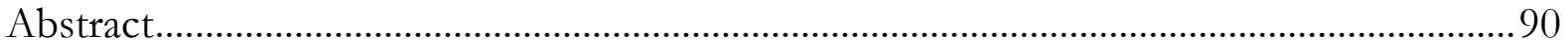

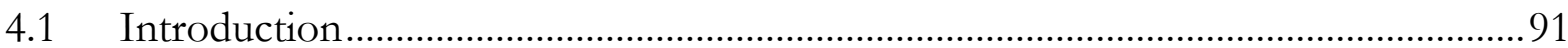

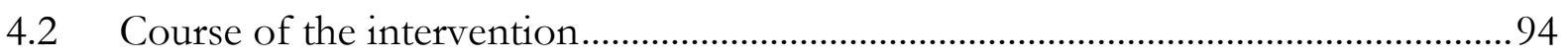

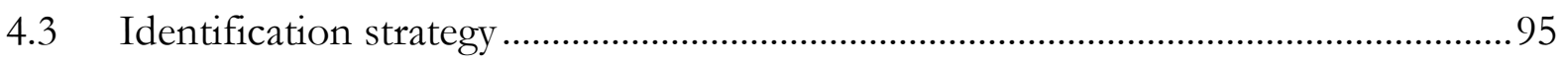

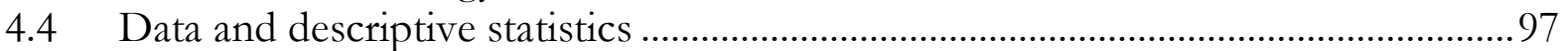

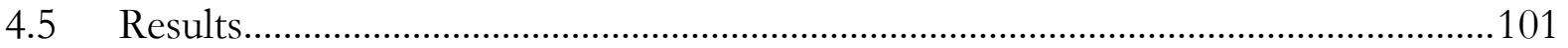

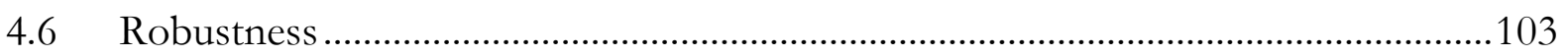

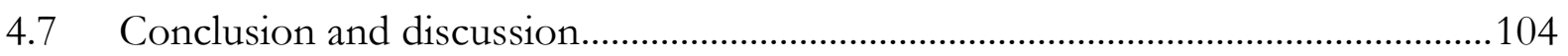

Appendix 4.1: Geographical distribution of treated and untreated schools.......................107

Appendix 4.2: Empirical distribution of the estimated intent-to-treat (ITT) effects ........108

Appendix 4.3: Difference-in-differences estimates full table ............................................110

\section{Chapter 5 - Study Choice Regret among Vocational Education Graduates: The} Role of Unanticipated Labour Market Conditions ....................................................115

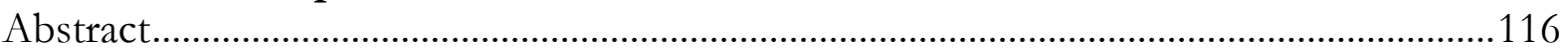

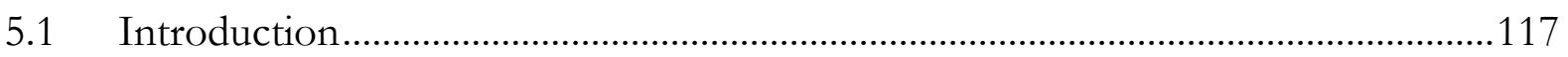

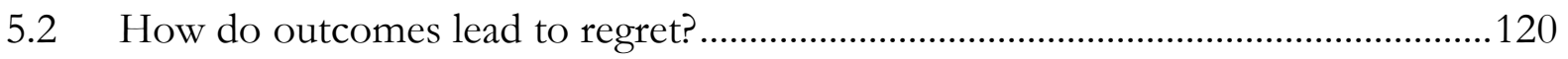

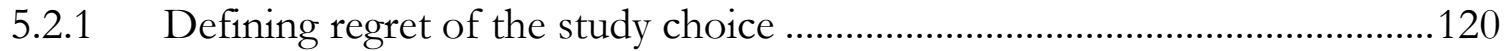

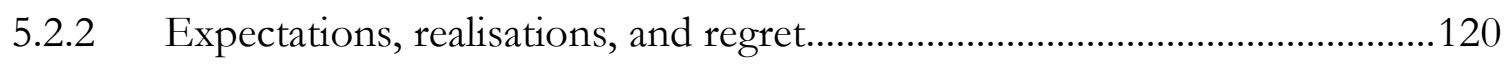

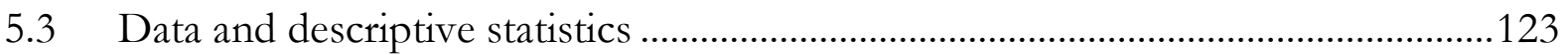

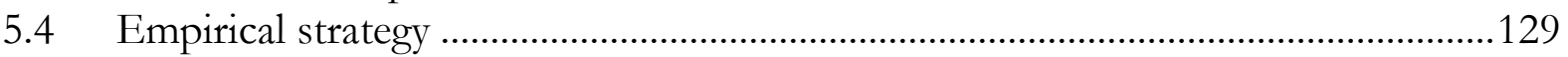

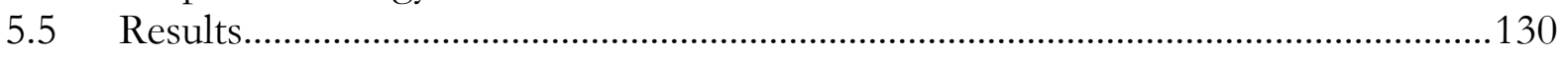

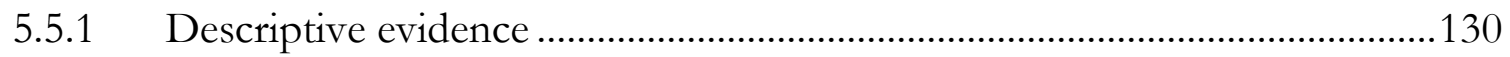

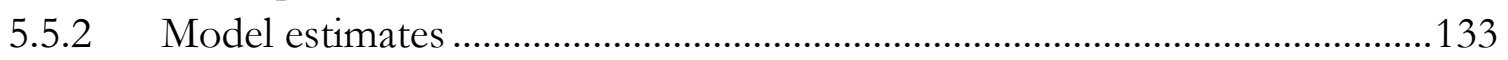

5.5.3 Asymmetry of labour market changes ...........................................................136

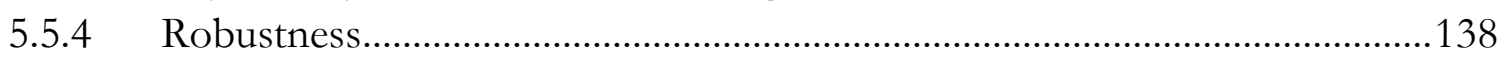

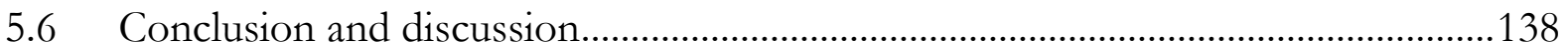

Appendix 5.1: Results when the actual unemployment rate is gender specific and the expected unemployment rate is non-gender specific........................................................141 


\section{Part 3 - Gaining Insight Into Future Labour Demand}

Chapter 6 - The Changing Demand for Skills in the Netherlands ..........................147

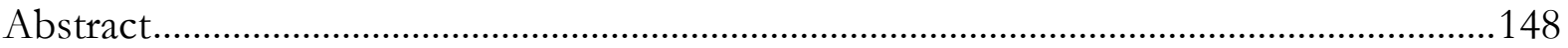

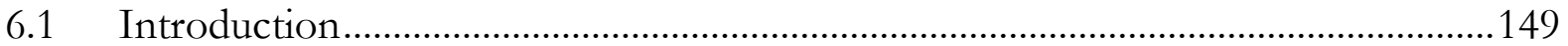

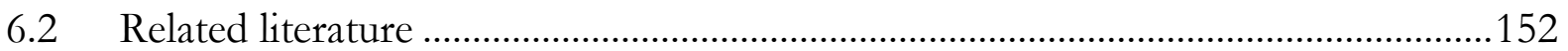

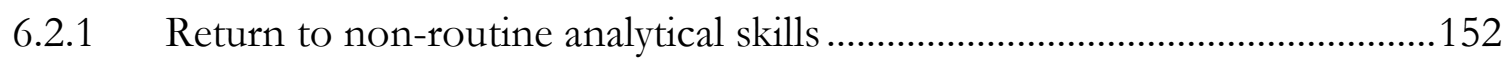

6.2.2 The return to non-routine interpersonal skills .............................................153

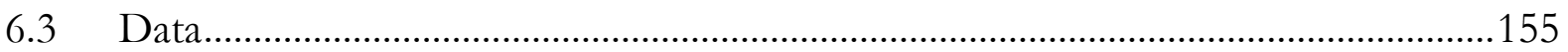

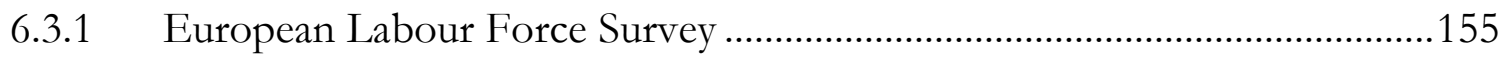

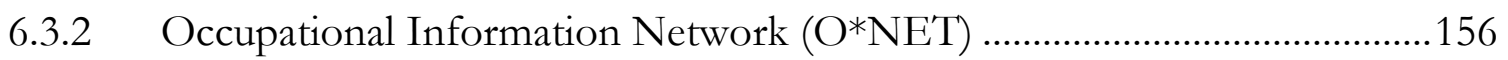

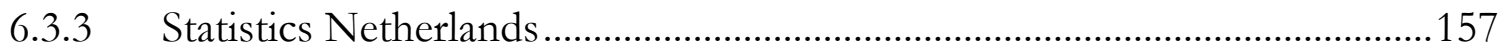

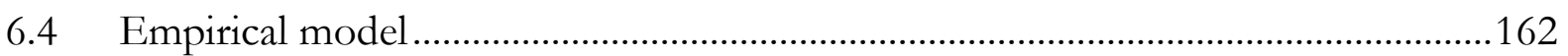

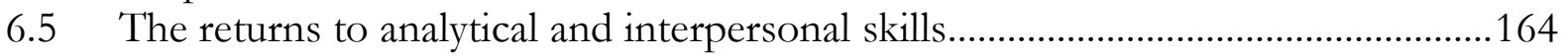

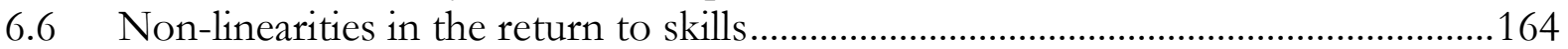

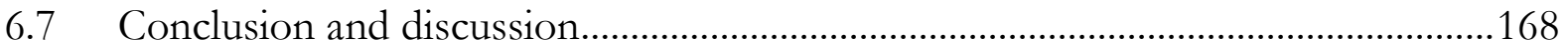

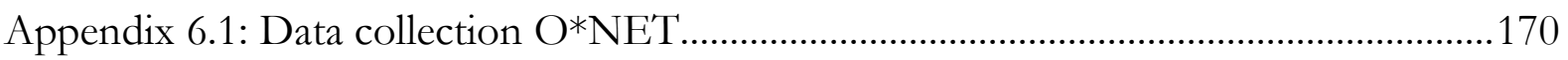

Appendix 6.2: Results for workers in full-time jobs ........................................................171

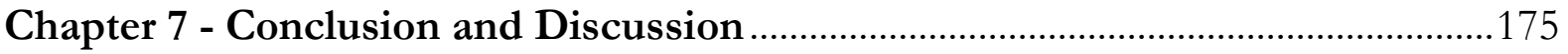

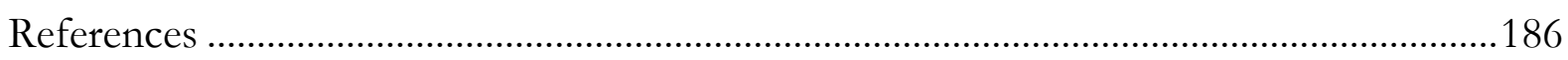

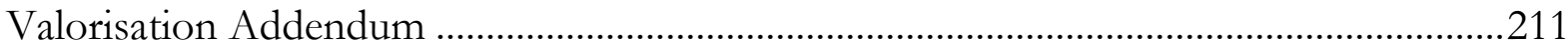

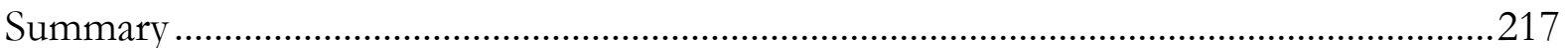

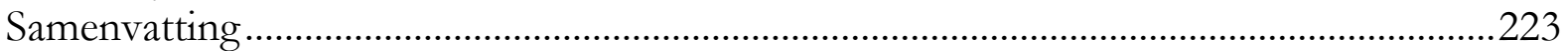

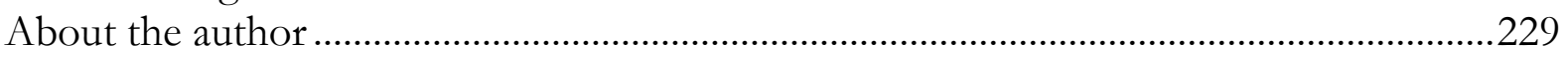

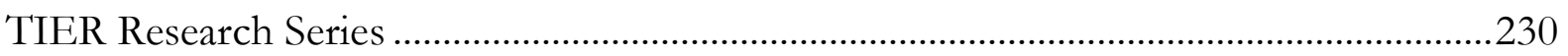




\section{List of Tables}

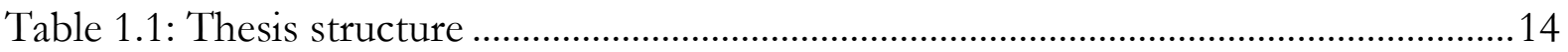

Table 2.1: General description of publications included in the review ...............................25

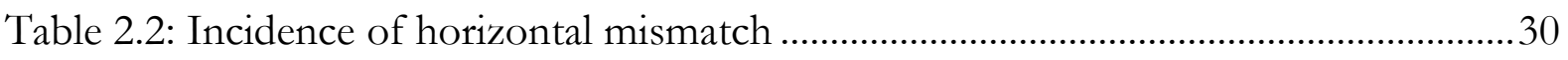

Table 2.3: Education-related determinants (individual level) of horizontal mismatch (= treated as the outcome variable) .......................................................................................... 34

Table 2.4: Education-related determinants (country level) of horizontal mismatch

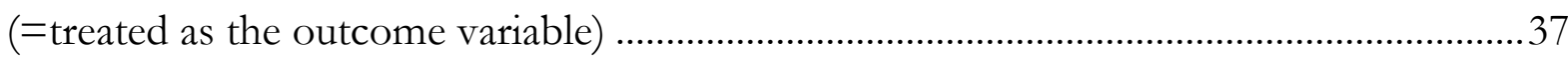

Table 2.5: Labour market-related determinants of horizontal mismatch (=treated as the outcome variable)

Table 2.6: Job-related determinants of horizontal mismatch (=treated as the outcome variable)

Table 2.7: Individual-related determinants of horizontal mismatch (=treated as the outcome variable)

Table 2.8: Parameter estimates of the outcomes associated with horizontal mismatch (= treated as the predictor variable here) ….................................................................................50

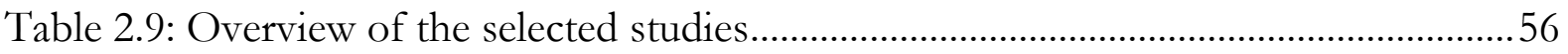

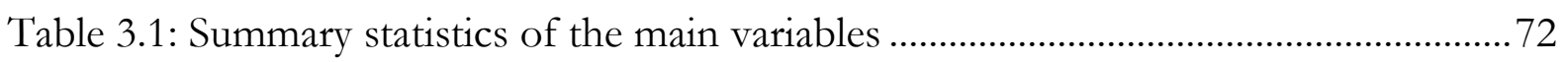

Table 3.2: Mismatch rates (weighted) 1991-2011 by sector...................................................74

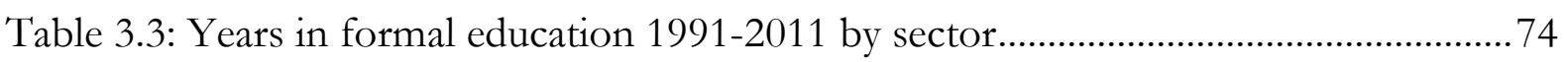

Table 3.4: Years in formal education on the regional labour market by gender..................75

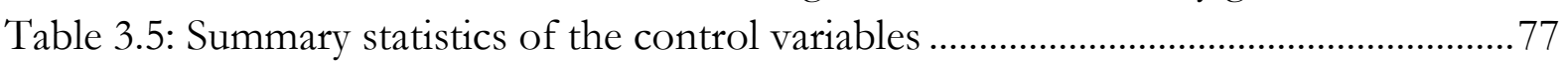

Table 3.6: Results of the pooled OLS estimates (Equation 1) …..........................................79

Table 3.7: Results of the 1st-stage estimates (Equation 2).................................................. 81

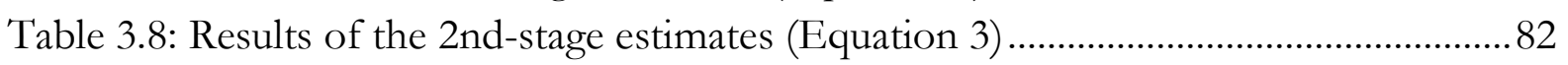

Table 3.9: Results of the second-stage estimates using a random effects specification..... 85

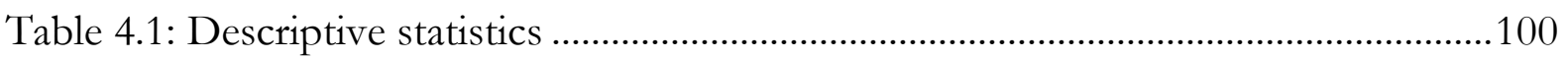

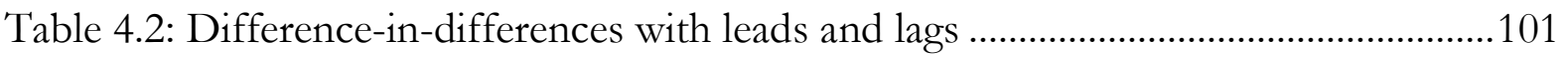

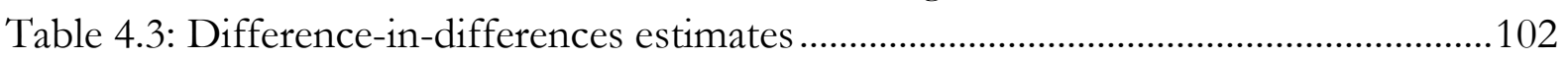

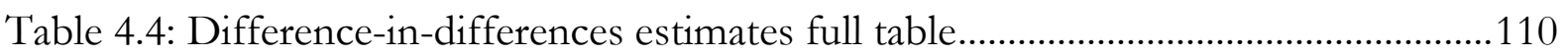

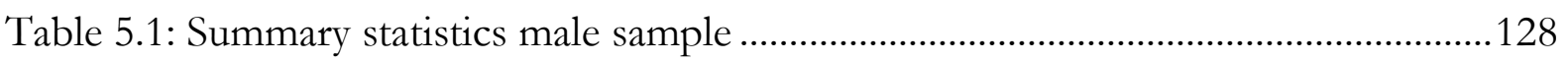

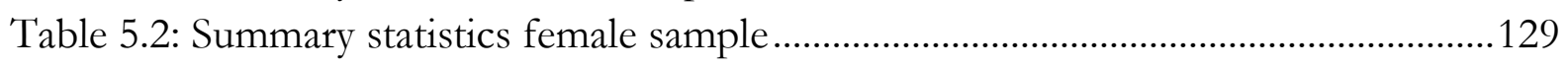

Table 5.3: Probit estimates for the relation between regret and unanticipated labour market conditions for male graduates

Table 5.4: Probit estimates for the relation between regret and unanticipated labour market conditions for female graduates

Table 5.5: Cases facing a higher unemployment rate upon labour market entry than expected

Table 5.6: Cases facing a lower unemployment rate upon labour market entry than expected.... 
Table 5.7: Relation between regret and unanticipated labour market conditions.

Table 5.8: Cases facing a higher unemployment rate upon labour market entry than expected

Table 5.9: Cases facing a lower unemployment rate upon labour market entry than expected

Table 6.1: Data availability

Table 6.2: Descriptive statistics 


\section{List of Figures}

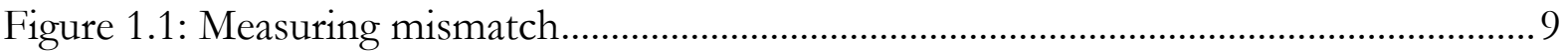

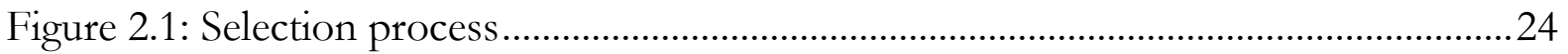

Figure 3.1: Employers' self-reported mismatch rates (weighted) 1991-2011 ......................73

Figure 3.2: Educational composition in the labour market 1990-2010................................76

Figure 4.1: Share of male students in pre-VET schools participating in the intervention 99

Figure 4.2: Empirical distribution of the ITT for native Dutch male students when a

binary treatment indicator is used and all control variables are included ..........................108

Figure 4.3: Empirical distribution of the ITT for native Dutch male students when a

continuous treatment indicator is used and all control variables are included..................108

Figure 4.4: Empirical distribution of the ITT for immigrant background students when a

binary treatment indicator is used and all control variables are included .........................109

Figure 4.5: Empirical distribution of the IT'T for immigrant background students when a

continuous treatment indicator is used and all control variables are included..................109

Figure 5.1: Discrepancy between expected and actual unemployment rate and regret ...131

Figure 6.1: The returns to analytical and interpersonal skills ...........................................165

Figure 6.2: The returns to analytical and interpersonal skills - Private sector workers ... 165

Figure 6.3: The returns to analytical skills: quantile regression estimates ..........................167

Figure 6.4: The returns to interpersonal skills: quantile regression estimates ..................167

Figure 6.5: The returns to analytical and interpersonal skills - Full-time workers...........171

Figure 6.6: The returns to analytical and interpersonal skills: Full-time private sector workers.

Figure 6.7: The returns to analytical skills: quantile regression estimates - Full-time workers

Figure 6.8: The returns to interpersonal skills: quantile regression estimates - Full-time workers. 



\section{Chapter 1}

General Introduction 


\section{$1.1 \quad$ Introduction}

The mismatch between the supply of human capital and the demand for labour gained renewed attention following the global financial crisis of 2007-2008. The financial crisis resulted in a substantial increase in the number of unemployed workers in developed economies. At the same time, thousands of open vacancies remained unfilled. In the Netherlands, the number of unemployed workers increased to 367,000 individuals in the first quarter of 2008, while the number of unfilled vacancies during the same period was approximately 247,000 (Statistics Netherlands, 2019a, 2019d). ${ }^{1}$ This phenomenon is often ascribed to a mismatch or imbalance between education (or skill) supply and education (or skill) demand in the labour market (Quintini, 2011b). During recessions, the mismatch discussion is usually focussed on how an excess supply of labour forces highly educated workers to accept jobs below their level of education. Highly educated workers thereby crowd out less educated workers from their jobs (Gautier et al., 2002). The mismatch between the supply of human capital and the demand for labour is not only a recurring theme in economic downturns; the topic also receives a great deal of attention in periods of economic expansion. By the end of 2018, the unemployment rate in the Netherlands had dropped to its lowest point in almost a decade (Statistics Netherlands, 2019c). On average, there were 80 job openings available per 100 unemployed individuals, a level that was last observed before the outbreak of the financial crisis in 2008. The tight labour market shifted the current mismatch debate towards one about labour shortages.

Provided that different stages of the business cycle are characterized by different types of mismatch (Lazaer \& Spletzer, 2012; Liu, Salvanes \& Sørensen, 2016), the prevalence of a specific form of skill imbalance is subject to considerable change in short time spans. Thus, rather than concentrating on the present state of skill mismatch in the Netherlands, this thesis focusses on the pervasiveness of skill mismatch in view of long-term labour market developments. Moreover, this thesis aims to explore what measures can be taken to prevent skill mismatch in the long run.

While cyclical changes result from a temporary shortfall in aggregate demand, structural trends in the supply and demand for labour alter the task composition of jobs and consequently affect long-term skill requirements. At the demand side of the labour market, structural trends such as technological change have reduced the demand for workers performing routine tasks, while it has placed greater demands on skilled workers

\footnotetext{
1 The unemployed comprise all individuals between the age of 15 and 65, who work less than 12 hours per week, who carried out activities to seek employment in the previous four weeks, and who were currently available to take up employment. The statistics are seasonally adjusted.
} 
performing non-routine tasks (Autor \& Dorn, 2013; Autor, Levy \& Murnane, 2003; Blinder, 2009; Goldin \& Katz, 2008; Goos, Manning \& Salomons, 2014). At the supply side of the labour market, the Netherlands has experienced an educational upgrading of the labour force over recent decades (Statistics Netherlands, 2019b). Although the expansion of higher education has been accompanied by an increasing demand for tertiary education graduates, this trend has also led to increased wage inequality among highly educated workers (Budría \& Moro-Egido, 2008; Gosling, Machin \& Meghir, 2000; Ingram \& Neumann, 2006). Moreover, the earnings differentials across fields-of-study can be larger than the earnings premium associated with a specific level of education (Altonji, Blom \& Meghir, 2012; Kirkebøen, Leuven \& Mogstad, 2016). These trends suggest that the type of field-specific skills are an increasingly important predictor of individuals' labour market success.

In light of the above-mentioned developments, this thesis addresses what the implications of these structural changes have been for the quality of worker-job matches from a historical perspective as well as for the skill requirements on the Dutch labour market. Moreover, this thesis investigates the pervasiveness of field-of-study mismatches in the labour market and explores what measures can be taken in order to improve the field-of-study choices of youngsters.

Gaining a better understanding of the size and nature of skill mismatch is of utmost importance given that job mismatches can entail serious consequences for the mismatched individual as well as for society. At the individual level, skill mismatch can result in an increased risk of long spells of unemployment (Groshen \& Potter, 2009); wage penalties (Groot \& Maassen van den Brink, 2000); job dissatisfaction (McGuinness \& Sloane, 2011; Verhaest \& Omey, 2006); and the erosion of human capital (Ball, 2009). From a societal perspective, education can be considered an expensive outlay that society makes through public investment in education (Hanushek, 2009; Levin et al., 2007). The highest return on this investment for society comes about when individuals are wellmatched to employers, such that the human capital acquired through education and onthe-job training can be optimally utilized in the labour market. Skill mismatches are undesirable as we pay a 'social price' for job mismatches. Such costs may relate to foregone returns on public investment in education, in the form of both tax revenue and unemployment allowances.

Addressing mismatch has gained prominence on many policy agendas, and policy makers are increasingly aware of the importance of anticipating human capital demands in the labour market to foster innovation and economic growth (e.g. European Economic and Social Committee, 2018). This is reflected, among other things, in the Horizon $2020 \mathrm{EU}$ 
strategy and European Commission initiatives such as 'New Skills for New Jobs' and 'New Skills Agenda for Europe' (European Commission, 2008, 2016). The initiatives particularly aim at supporting the EU member states in identifying and forecasting future skill demands on local or regional labour markets as well as on the formation of those skills. It also aims at smoothing the transition from education to work. Furthermore, the European Social Fund invests 75 billion euros in training and education schemes to help thousands of people, both employed and unemployed, acquire these 'new skills'. The development of effective skills strategies has also gained increased policy attention in the Netherlands (OECD, 2017).

The aim of this thesis is threefold. The first aim of the research presented in this thesis is to provide insight into the extent to which skill mismatch is present in the labour market. By means of a systematic review, I examine to what degree employees experience a mismatch between the job and the field-of-study, and what the determinants and consequences are of this type of mismatch. As a result of the increasing number of students holding a higher education degree, the field-of-study has become an increasingly important predictor of graduates' success in the labour market (Altonji et al., 2012; Kirkebøen, et al., 2016). Therefore, increasing our understanding of how prevalent jobeducation mismatches are in terms of the field-of-study, and how such mismatches can be prevented, is of direct interest to individuals and policy makers.

In addition, the research in this thesis illustrates how skill mismatch has developed over the past two decades from the perspective of Dutch employers. Between the period 1991-2011, Dutch employers were asked biannually whether their workforce was sufficiently equipped to meet the job task requirements in the coming years. This question captures various types of mismatch, as it encouraged employers to think not about whether their workforce lacked the right level of skills, but also whether the workforce lacked the right type of skills. Consequently, I investigate whether the educational upgrading of the Dutch workforce can explain the mismatch trend observed over time.

The second aim of the research presented in this thesis is to shed light on what interventions can potentially prevent future skill mismatch in the labour market. One of the mismatch types that is widely experienced in Europe, including in the Netherlands, is a shortage of Science, Technology, Engineering, and Mathematics (STEM) workers. The demand for STEM graduates has increased in most EU countries and is expected to grow further in the coming years (BusinessEurope, 2011; Cedefop, 2014a; Cedefop, 2014b; European Commission, 2014; ROA, 2017a). However, the supply of STEM graduates, in particular from upper-secondary vocational education and training (VET), is expected to 
fall behind demand (Cedefop, 2014b; European Parliament, 2015; ROA, 2017a). This thesis evaluates the effectiveness of a five-day intervention that was designed to motivate students to enrol in STEM education in VET.

Next, I will investigate whether increasing the availability of forecast information could potentially improve the quality of students' field-of-study choice and thereby prevent mismatch. As pointed out earlier, graduates increasingly differentiate themselves from other graduates in the labour market through their field-of-study background. Accordingly, the development of relevant indicators of future field-specific labour demand to assist prospective students in their education choice has received growing attention in the Netherlands. The analyses focus on graduates from VET. Changes in labour market conditions are of particular relevance to these graduates, due to the strong link between the skills learned at school and the occupational demands for such skills.

The third and final objective of this dissertation is to investigate how the demand for skills has changed over time in the Netherlands. Labour markets are subject to rapid changes (OECD, 2018). Thus, improving our understanding of deviations in the composition of job tasks can help to prevent bottlenecks in the labour market. This thesis documents how skills are rewarded on the Dutch labour market and, by using newly developed occupational skill profiles, how this has altered over the last decades.

\subsection{Defining mismatch}

Skill mismatch is a frequently used term which refers to various types of imbalances between the supply of human capital and the demand for labour. Although the term skill mismatch might suggest that it purely pertains to skill imbalances, mismatch rather refers to a surplus or a lack of knowledge, skills, and attitudes that enable individuals to perform tasks in either a defined or a variety of work contexts (ILO, 2014; Roe, 2002). For simplicity, the term 'skill mismatch' will be used throughout this thesis to refer to any type of imbalance between the knowledge, skills, and attitudes possessed by workers and those that are demanded in the labour market. Skill mismatch is generally restricted to situations concerning employed individuals or firms that currently employ or seek to employ workers. While unemployment can be thought of as a form of mismatch, it is generally disregarded in the context of this literature.

The literature identifies various types of mismatch that can be analysed at different levels; at the micro-level (worker or firm), but also at the macro-level. At the level of individual workers, the literature identifies at least two broad types of mismatch between skill provision and skill demand in the labour market: vertical and horizontal. Vertical mismatch refers to situations in which graduates are over- or under-educated for the job. 
In the case of over-education (under-education), workers have acquired more (less) schooling or skills than is required for the job (Hartog, 2000; McGuinness, 2006). A mismatch between the job and the field-of-study is also referred to as horizontal mismatch (Robst, 2007a).

To identify mismatch at the firm level, the literature generally refers to skill gaps and skill shortages. Skill gaps relate to the extent that a firm's workforce lacks the level of skills required to perform their jobs. Firms face skill shortages when employers have difficulty finding qualified workers to fill vacancies. If employers demand other knowledge and skills from graduates who studied the right field-of-study to match the job, such workers are considered as experiencing intra-curricular mismatch (Marzo-Navarro, PedrajaIglesias \& Rivera-Torres, 2009). This is a special and often forgotten type of mismatch that shows how the provision of a rigid course of education can hinder the teaching of the changing skill requirements demanded in dynamic labour markets (Lamo \& Messina, 2010).

Finally, at the macro level, mismatch measures can be derived from trends in vacancy and unemployment rates. The next section provides a brief overview of how mismatch has been measured in the literature (summarized in Figure 1.1).

\subsubsection{Measuring mismatch at the worker level}

Three approaches have been used frequently to measure vertical and horizontal mismatch (see type of mismatch in Figure 1.1) at the worker's level (see level of measurement in Figure 1.1): the subjective approach, the objective approach, and the independent job analysis (see measurement approach in Figure 1.1). Measures of vertical or horizontal mismatch are typically derived from comparing a worker's acquired level or field-of-study with the educational requirements for job entrance.

\section{Subjective approach (worker self-assessment)}

In the subjective approach, vertical mismatch is measured by either asking workers directly whether they are over-educated for the work they do (e.g. Chevalier, 2003), or by asking workers to indicate the required level of education which is then compared with workers' own level of education (e.g. Quintano, Castellano \& D'agostino, 2008). Horizontal mismatch is typically measured by asking workers whether their field-of-study is related to the job (Robst 2007a; Bender \& Roche, 2013). The advantage of the subjective approach is that it is specifically concerned with respondents' job, and not with any type of aggregate of that occupation. A disadvantage of this approach is that workers with the same educational background might have diverging perceptions regarding the 
job-education match. Moreover, educational qualifications might ignore the potential heterogeneity between graduates (Allen \& Van der Velden, 2001). Measures based on formally required levels of education can also be problematic in the case of educational inflation, meaning that employers require a higher level of education than is actually needed to perform the job.

\section{Objective approach (realised matches)}

While the educational requirements set out by employers may become obsolete over time, data-based methods constantly adjust to changing conditions in the workplace (Kiker, Santos \& de Oliveira, 1997). In the objective or realized matches approach, the required schooling level of a worker is inferred from the schooling level of workers in the same occupation, e.g. the mean or modus of that distribution. A worker is defined as over- or under-educated when the acquired years of schooling varies at least one standard deviation from the mean or mode in their occupation (see e.g. Kiker et al., 1997; Verdugo \& Verdugo, 1989). The application of the objective approach in the literature on field-ofstudy mismatch is rare. Recently, Nieto, Matano and Ramos (2015) applied this method by measuring the required field-of-study by the modal field-of-study within each occupational group.

A limitation of the objective approach is that it neglects variation in educational requirements across jobs in the same occupational group. Furthermore, the average or modal schooling level results from supply and demand forces. Thus, in periods of an oversupply of graduates, the average level of education will increase and cause a downward bias in the incidence of true over-education.

\section{Independent job analysis}

In the normative or independent job analysis method, professional job analysts provide the required level and type of education for the job titles in a standard occupation classification such as the US Dictionary of Occupational Titles (DOT) (see e.g. McGoldrick \& Robst, 1996; Rumberger, 1987). Horizontal mismatch can also be measured objectively by comparing a field-of-study variable with occupation codes (Wolbers, 2003). An attractive feature of this method is that educational requirements are determined on the basis of the technology of the job and the type of activities that need to be carried out. However, job analyses require a precise and systematic approach and are therefore expensive when executed on a large scale. As a consequence, updates of occupational classifications take place infrequently. 


\subsubsection{Measuring mismatch at the firm level}

At the firm level, indicators for skill gaps are typically derived from employer information on the perceived skill deficits of workers (e.g. McGuinness \& Ortiz, 2016). In contrast, skill shortages can be measured by asking employers whether they experience difficulties in filling vacancies (e.g. Bennett \& McGuinness, 2009; Haskel \& Martin, 2001). Intracurricular mismatch has been measured by comparing the curriculum studied by students and the qualifications demanded by firms (e.g. Mazro-Navarro, Pedraja-Iglesias \& RiveraTorres, 2009). Mazro-Navarro et al. (2009) asked firms to specify which curricular aspects graduates need to possess in order to carry out job tasks. Likewise, students were asked to assess the level of competencies, content and skills they were obtaining through their university education. To identify a possible curricular mismatch, the means of each item provided by students and firms were compared.

\subsubsection{Macro-economic indicator of mismatch}

At the macro-level, mismatch is typically described and depicted by the Beveridge curve. The Beveridge curve reflects the relation between the vacancy and the unemployment rate within a country or region (Dow \& Dicks-Mireaux, 1958; Lazaer \& Spletzer, 2012). An inward movement of the Beveridge points toward a better functioning labour market with a lower vacancy and unemployment rate, while an outward shift of the curve is indicative of an increasing risk of mismatch and structural unemployment. An outward moving curve points toward an increasing number of unemployed individuals for a given vacancy rate, implying that the match between job seekers and vacancies is realized less easily. Mismatch occurs when the skills or location of workers poorly match vacancies. Macro-economic indicators of mismatch are a macro-translation of individual-level phenomena and have been proposed due to the unavailability of individual level mismatch indicators. 
Figure 1.1: Measuring mismatch
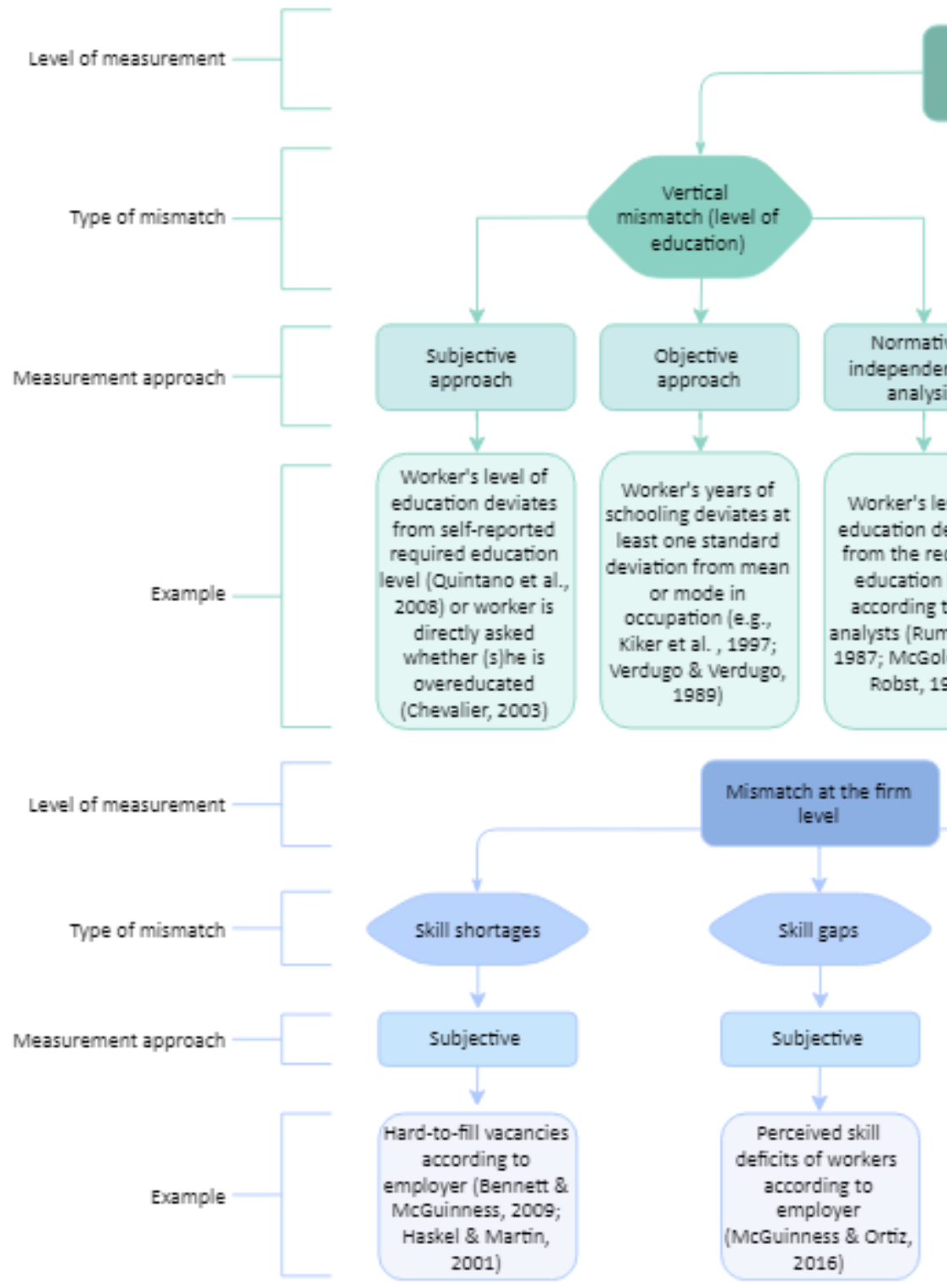

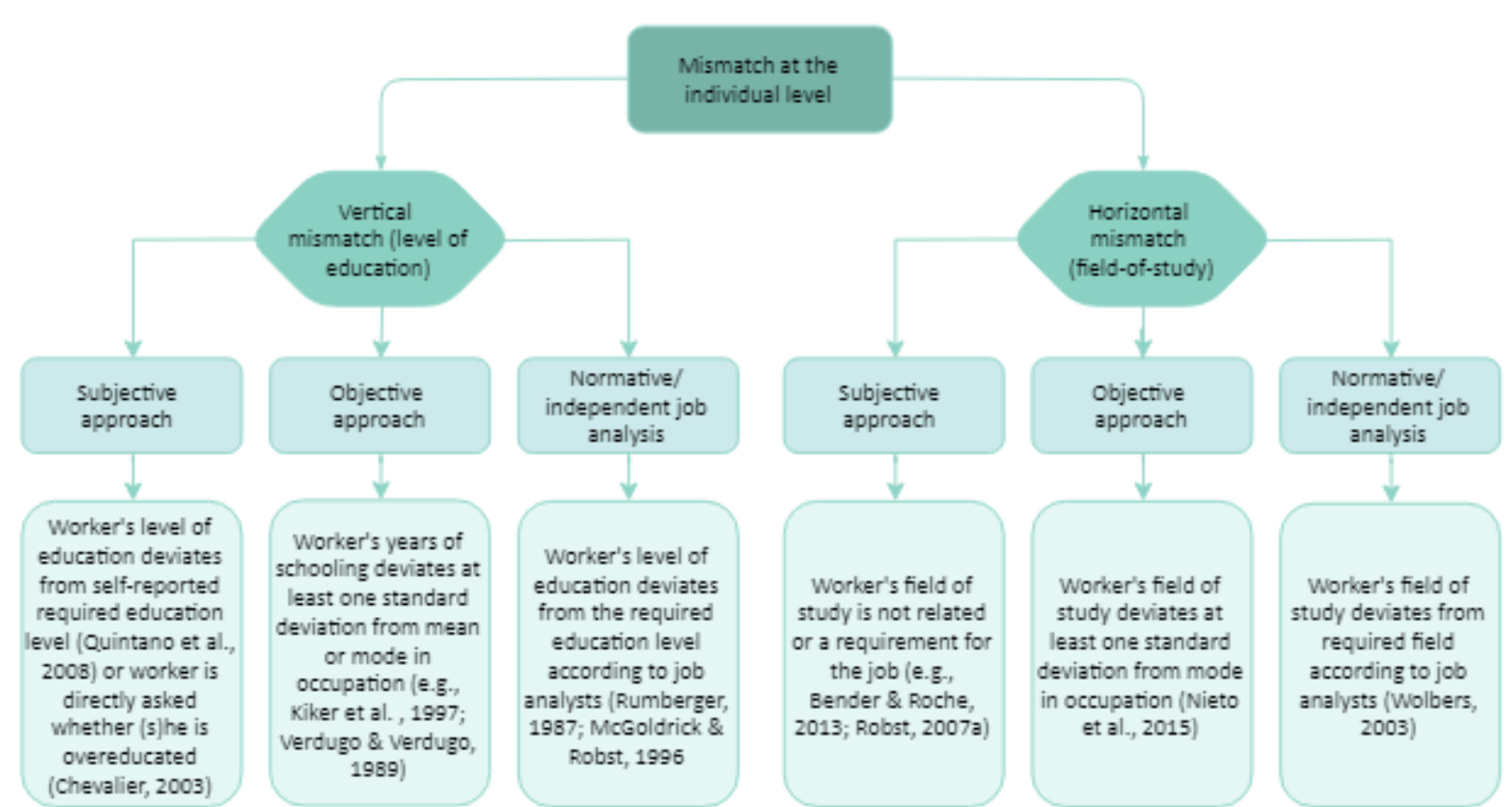

Mismatch at the macro-
economic level economic level

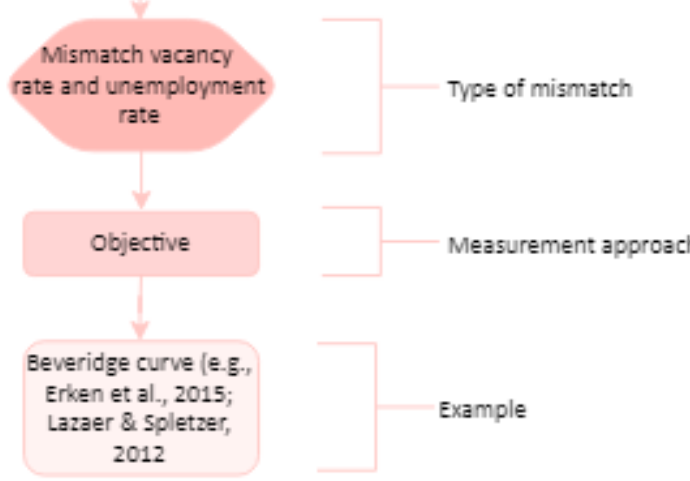




\subsection{Scientific contributions of the thesis}

This section provides a brief overview of the current position of the mismatch literature and indicates how the studies contribute to this body of research. The literature on vertical mismatch has grown enormously since the late 1980s. ${ }^{2}$ This trend followed from the fact that in the last decades, developed countries have witnessed a substantial increase in the number of graduates from higher education (Autor, Katz \& Krueger, 1998; Goos, Manning \& Salomons, 2009, OECD, 2014). Many scholars have argued that the rapid expansion of educational participation rates has resulted in an over-supply of higher education graduates (e.g. Hartog, 2000; Di Pietro \& Urwin, 2006). Various studies have reviewed the literature on the incidence, consequences, and determinants of overeducation in response to the increasing amount of empirical research on vertical mismatch (e.g. Groot \& Maassen van den Brink, 2000; Hartog, 2000; McGuinness, 2006; Quintini, 2011a; Rubb, 2003). Research consistently shows that over-educated or overskilled workers suffer from wage losses and are more likely to experience job dissatisfaction (Green \& Zhu, 2010; Groot \& Maassen van den Brink, 2000; McGuinness \& Sloane, 2011; Sánchez-Sánchez \& McGuinness, 2015; Verhaest \& Omey, 2006).

The literature on horizontal mismatch is relatively sparse compared to the literature on vertical mismatch. Although the literature on field-of-study mismatch is expanding, an extensive review and discussion of this stream of literature has not been available to date. Only Sellami, Verhaest and Van Trier (2018) provide a comparative analysis of the different methods to measure horizontal mismatch. The first contribution of the research this thesis is to provide a systematic review of the growing literature on horizontal mismatch. The review discusses how horizontal mismatch can be measured and provides insight into the incidence, determinants, and consequences of horizontal mismatch.

Another characteristics of the vertical mismatch literature is that much of its attention has focussed on the implications of expanding access to higher education from the perspective of graduates. However, little empirical evidence is available regarding the consequences of the increased educational participation rates from employers' view. A small number of studies have investigated the relationship between firm productivity and the presence of over-educated workers in the firm. Tsang (1987) demonstrated that overeducated workers are more likely to experience job dissatisfaction which is in turn negatively related to firm productivity. In contrast, Kampelmann and Rycx (2012) found that additional years of over-qualification have a positive impact on firm productivity. The research in this dissertation contributes to the literature by providing new empirical

\footnotetext{
2 McGuinness, Pouliakas and Redmond (2017), for example, provide a review of the literature on mismatch and found 86 papers on over-education that have been published between 2006-2016.
} 
evidence on whether employers have benefitted from the enhanced educational level of the labour force. For this purpose, a unique measure of skills mismatch is used, based on employers' surveys. In particular, I examine to what extent the workforce of Dutch companies had been equipped to meet the task requirements of their jobs during the period 1991-2011. The novelty of this mismatch measure is that it not only captures the skills that employees have acquired through formal education, but it also indicates whether employees possess the skills and knowledge meet the requirements of their job. Consequently, this thesis explores how the educational upgrading of the Dutch labour force has contributed to the development of mismatch form the employers' perspective.

The next contribution concerns the scientific evidence on what works to address skill shortages in the labour market. The evidence on what interventions can motivate students to enrol in a STEM-related study programme is largely limited to the effect of interventions on short-term outcomes such as students' interest in pursuing STEMcareers (e.g. Rosenzweig \& Wigfield, 2016). Moreover, the majority of the evaluated interventions have not been designed for vocational education students and do not allow for a causal interpretation (e.g. Bamberger, 2014; Greenes et al., 2011; Hiller \& Kitsantas, 2014; Kim \& Chae, 2016; Welch, 2010). In contrast to earlier studies, I examine the causal effect of a five-day intervention on actual enrolment rates into STEM-education in Dutch VET.

Furthermore, this dissertation investigates whether the quality of vocational students' field-of-study choice could be improved by improving the availability of forecast information. Although this cannot be tested directly, I assess whether unanticipated changes in labour market conditions affect youngsters' regret about their field-of-study. If this is the case, increasing the availability of labour market forecasts by field-of-study would be of added value. To the best of my knowledge, the relationship between labour market conditions and subsequent regret about the chosen field-of-study has only been studied by Borghans and Golsteyn (2005). In contrast to Borghans and Golsteyn (2005), I use a longer time frame that covers multiple economic cycles with rising and falling youth unemployment. Field-of-study regret can be considered a useful indicator of the match between education and the labour market, as it is associated with graduates' labour market outcomes such as horizontal and vertical mismatch (Kucel \& Vilalta-Bufí, 2013; Mora, 2010).

Finally, to ensure a good match between the skill supply and demand in the labour market, it is of utmost importance to gain a better understanding of the way in which the demand for skills is changing in the Dutch labour market. Although skills are a major policy priority in the Netherlands (SER, 2017), the available measures of the skills that 
the labour force possesses and that are required on the Dutch labour market are imperfect. Individual educational qualifications typically serve as a proxy for the supply of skills. However, qualifications are only loosely linked to job skills and thereby to individual and economy-wide performance (Hanushek \& Woessmann, 2008). Moreover, the acquisition of skills continues after formal education is completed. This thesis is the first to present estimates of how the demand for skills has changed in the Dutch labour market over the period 2001-2016 using newly developed occupational skill profiles. In particular, I investigate how the reward for a job that is intensive in non-routine tasks has developed over the past two decades. According to the routinization hypothesis (Autor et al., 2003), technological improvements have reduced the demand for skills required to perform routine tasks, while they have increased the demand for skills that typically complement it, namely, skills required to perform non-routine abstract tasks.

\subsection{Thesis outline}

This thesis encompasses three core parts; Part I covers the incidence and determinants of skill mismatch, Part II addresses how mismatch can be prevented, and Part III provides insight into future labour demand (see Table 1.1). Part I contains two chapters on the incidence and determinants of mismatches between individuals' human capital and employment. Chapter 2 provides a systematic literature review of international studies investigating the mismatch between employment and the field-of-study. This chapter discusses how horizontal mismatch has been operationalized in the literature and what the advantages and limitations are of each measurement. The chapter then presents to what extent horizontal mismatch is present in international labour markets and discusses what the determinants and consequences of horizontal mismatch are. Finally, Chapter 2 provides a discussion regarding the conditions under which horizontal mismatch can be considered an undesirable phenomenon.

Chapter 3 presents a study in which historical trends in the match between workers' competencies and job task requirements are analysed for the period 1991-2011. The study discussed takes the perspective of Dutch employers to determine worker-job matches. Subsequently, it is examined to what extent the trend in worker-job matches can be explained by the educational upgrading of the Dutch labour force over the past decades.

Part II of this thesis focusses on what interventions can potentially prevent mismatches in the labour market. Chapter 4 provides an evaluation of a five-day study choice programme conducted in the Amsterdam Metropolitan Area in the schoolyear 2014-15. The intervention aimed at encouraging students from preparatory vocational education to

choose STEM education in upper-secondary VET. Chapter 5 provides insight into the potential role of labour market forecasts by field-of-study in upper-secondary VET. In 
particular, this chapter studies the relationship between unanticipated changes in labour market conditions and field-of-study choice regret among graduates.

Part III sheds light on the changing skill requirements in the Dutch labour market. Chapter 6 examines how the rewards for different types of skills have changed in the Dutch labour market over the period 2001-2016. In particular, I document how the demand for non-routine analytical skills and non-routine interpersonal skills have developed over the past two decades. Finally, in Chapter 7 , the conclusions of this thesis are presented and discussed. Chapter 7 discusses the policy implications of the research findings as well as the limitations and guidance for future research. 
Table 1.1: Thesis structure

\begin{tabular}{|c|c|c|c|c|c|}
\hline & Chapter & Subject & Method & Population studied & Findings \\
\hline \multirow{3}{*}{$\begin{array}{l}\text { Part I - } \\
\text { Incidence and } \\
\text { determinants } \\
\text { of mismatch } \\
\text { between } \\
\text { human capital } \\
\text { and labour } \\
\text { demand }\end{array}$} & Chapter 1 & $\begin{array}{l}\text { Introduction, aims and } \\
\text { contributions of the thesis, } \\
\text { and thesis outline }\end{array}$ & & & \\
\hline & Chapter 2 & $\begin{array}{l}\text { Horizontal mismatch } \\
\text { The incidence, determinants } \\
\text { and consequences of a } \\
\text { mismatch between } \\
\text { employment and the field- } \\
\text { of-study }\end{array}$ & $\begin{array}{l}\text { Systematic } \\
\text { literature } \\
\text { review }\end{array}$ & $\begin{array}{l}\text { School-leavers in a range of } \\
\text { developed countries }\end{array}$ & $\begin{array}{l}\text { Being employed in a job that is unrelated to the } \\
\text { field-of-study is associated with undesirable } \\
\text { outcomes when field-specific skills are } \\
\text { underutilised. A more uniform measure of } \\
\text { horizontal mismatch is required to reflect the } \\
\text { extent to which skills are underutilised. }\end{array}$ \\
\hline & Chapter 3 & $\begin{array}{l}\text { Skill gaps } \\
\text { The (mis)match between job } \\
\text { task requirements and } \\
\text { workers' competencies and } \\
\text { the role of the expansion of } \\
\text { higher education }\end{array}$ & $\begin{array}{l}\text { Instrumental } \\
\text { variables } \\
\text { approach }\end{array}$ & $\begin{array}{l}\text { Workforce of Dutch firms } \\
\text { and Dutch employers }\end{array}$ & $\begin{array}{l}\text { The match between workers' skills and the job } \\
\text { requirements substantially improved over the } \\
\text { period 1991-2011 from the perspective of } \\
\text { employers. The educational upgrading of the } \\
\text { labour force contributed to this trend. }\end{array}$ \\
\hline \multirow[t]{2}{*}{$\begin{array}{l}\text { Part II - } \\
\text { Preventing } \\
\text { mismatch } \\
\text { between } \\
\text { human capital } \\
\text { and labour } \\
\text { demand }\end{array}$} & Chapter 4 & $\begin{array}{l}\text { Skill shortages } \\
\text { The effectiveness of a five- } \\
\text { day intervention that aimed } \\
\text { at encouraging students to } \\
\text { choose for a STEM related } \\
\text { study programme }\end{array}$ & $\begin{array}{l}\text { Difference- } \\
\text { in- } \\
\text { differences } \\
\text { estimator; } \\
\text { propensity } \\
\text { score } \\
\text { matching }\end{array}$ & $\begin{array}{l}\text { Preparatory vocational } \\
\text { education male students who } \\
\text { are about to choose a field-of- } \\
\text { study in upper-secondary } \\
\text { vocational education in the } \\
\text { Amsterdam Metropolitan } \\
\text { Area in the Netherlands }\end{array}$ & $\begin{array}{l}\text { The five-day intervention did not affect native } \\
\text { Dutch students' probability to enrol into STEM } \\
\text { education in VET, but had a small positive effect } \\
\text { on students with an immigrant background. }\end{array}$ \\
\hline & Chapter 5 & $\begin{array}{l}\text { The relation between field- } \\
\text { of-study choice regret and } \\
\text { unanticipated changes in } \\
\text { labour market conditions }\end{array}$ & $\begin{array}{l}\text { Probit } \\
\text { model }\end{array}$ & $\begin{array}{l}\text { Upper-secondary vocational } \\
\text { education graduates in the } \\
\text { Netherlands }\end{array}$ & $\begin{array}{l}\text { Male graduates are more likely to regret their field- } \\
\text { of-study choice upon labour market entry when } \\
\text { experiencing unfavourable changes in labour } \\
\text { market conditions. }\end{array}$ \\
\hline \multirow[t]{2}{*}{$\begin{array}{l}\text { Part III - } \\
\text { Gaining insight } \\
\text { into future } \\
\text { labour demand }\end{array}$} & Chapter 6 & $\begin{array}{l}\text { The changing demand for } \\
\text { skills in the Netherlands }\end{array}$ & & $\begin{array}{l}\text { Employed individuals in the } \\
\text { Netherlands }\end{array}$ & $\begin{array}{l}\text { Non-routine analytical skills are increasingly } \\
\text { rewarded on the labour market. This holds true for } \\
\text { workers in the lower, middle-, and upper- end of } \\
\text { the wage distribution. In the higher wage segment, } \\
\text { non-routine skills are also increasingly rewarded. }\end{array}$ \\
\hline & Chapter 7 & Conclusions and discussion & & & \\
\hline
\end{tabular}






\section{Part 1}

Incidence and Determinants of Mismatch between

Human Capital and Labour Demand 



\section{Chapter 2}

\section{Horizontal Mismatch between Employment and Field of Education: Evidence from a Systematic Literature Review ${ }^{3,4,5}$}

3 This study is based on: Somers, M. A., Cabus, S. J., Groot, W., \& van den Brink, H. M. (2019). Horizontal mismatch between employment and field of education: Evidence from a systematic literature review. Journal of Economic Surveys, 33(2), 567-603. https://doi.org/10.1111/joes.12271

4 This study benefitted from discussions with participants of the XXV Meeting of the Economics of Education Association.

5 This study was financially supported by Stichting Instituut Gak under grant [2014-533]. Stichting Instituut Gak was not involved in the preparation of this chapter. 
Chapter 2

\begin{abstract}
This chapter discusses a systematic review of the growing literature on the poor match between employees' field-of-study and the job requirements, also referred to as horizontal mismatch. We identify the different definitions used in the literature and find that each measure of horizontal mismatch yields substantially different incidence rates. We discuss the validity of the different measures and conclude that a more uniform definition of horizontal mismatch is needed. The likelihood of horizontal mismatch is determined, among other things, by the extent to which employees possess general skills as opposed to occupation-specific skills, and it appears to be found more frequently among older workers. Compared to well-matched employees, horizontally mismatched workers generally incur a wage penalty, are less satisfied with their jobs, and are more likely to regret their study programme. The ensuing findings offer guidance to prevent horizontal mismatch as well as a roadmap for future research.
\end{abstract}




\subsection{Introduction}

The general introduction already emphasized that an adequate match between labour supply and labour demand is indispensable for graduates and companies and, consequently, for the economy as a whole. As discussed in Chapter 1, job-education mismatches are typically measured by comparing graduates' educational attainment with the requirements for the job which can be expressed in terms of the level (vertical mismatch) as well as the field-of-study (horizontal mismatch). The growth in the number of individuals graduating from higher education has in particular raised concerns about the incidence of over-educated (i.e. vertically mismatched) workers. As a consequence, the incidence, determinants and consequences of vertical mismatch have been well documented (see e.g. Chevalier, 2003; Dolton \& Silles, 2008; Dolton \& Vignoles, 2000; Duncan \& Hoffman, 1981; Groeneveld \& Hartog, 2004; Kiker et al., 1997; McGuinness \& Bennett, 2007; Verdugo \& Verdugo, 1989; Verhaest \& Omey, 2006), and various studies have provided useful summaries of this stream of literature by means of reviews as well as meta-analyses (e.g. Groot \& Maassen van den Brink, 2000; Hartog, 2000; McGuinness, 2006; Rubb, 2003; Sloane, 2003). Prior research consistently shows that a situation of over-education entails adverse outcomes for workers such as wage penalties and job dissatisfaction (e.g. Groot \& Maassen van den Brink, 2000; McGuinness \& Sloane, 2011).

The expansion of higher education not only gave rise to concerns about vertical mismatch, it has also led to increased wage inequality among highly educated workers (Budría \& Moro-Egido, 2008; Gosling et al., 2000; Ingram \& Neumann, 2006). In some instances, the earnings differentials across fields-of-study are even found to be larger than the earnings premium associated with a specific level of education (Altonji et al. 2012; Kirkebøen et al., 2016). As such, the field-of-study has become an increasingly important predictor of graduates' labour market success. As a response to these trends, the literature on the (mis)match between workers' job and their field-of-study has gained more attention. Despite the growing literature on horizontal mismatch and the importance of an adequate match between job requirements and the field-of-study, a review and discussion of this body of research has not been available to date.

Considering the potential economic losses associated with skill underutilisation, from a human capital theory perspective, horizontal mismatch can be considered an undesirable phenomenon. Given that a proper allocation of skills in the labour market is in the best interest of society, an important question to be raised is how prevalent horizontal mismatch is and under what circumstances welfare losses are generated. We address this through four sub-questions: (a) How is horizontal mismatch defined and measured? (b) 
To what extent is horizontal mismatch observed? (c) What are the determinants of horizontal mismatch? and (d) What are the consequences of horizontal mismatch? We answer the questions by means of a systematic review of the literature on mismatch between employees' job and their field-of-study. The objective of this chapter is to present an integrated summary of the existing body of knowledge of horizontal mismatch. We identify where the conclusions of previous research converge and diverge and set the agenda for future research.

This chapter proceeds as follows. The next section describes the literature search strategy. The results section addresses how horizontal mismatch has been measured as well as its advantages and drawbacks. This chapter then presents the incidence of horizontal mismatch and proceeds with discussing its determinants and consequences. Finally, this chapter discusses the main conclusions of this systematic review and provides suggestions for future research.

\section{$2.2 \quad$ Method}

For our review, we set a series of inclusion criteria to narrow the extensive body of research down to a manageable set of studies for a thorough analysis: (a) The study is published between 1995 and 2015 in peer-reviewed academic journals in the Dutch or English language. (b) Empirical studies (descriptive, correlational and experimental) are included, whereas theoretical, conceptual and case studies are excluded. (c) The study deals with a mismatch between employees' job and the attended field-of-study. Studies that focus on other types of mismatch (e.g. over- and under-education) were not retained.

We limit our literature search to the time window 1995-2015 as concerns about horizontal mismatch were first raised in 1995 by Witte and Kalleberg. Our systematic review is restricted to publications in the Dutch or English language due to a lack of resources and facilities for translation. We acknowledge that this restriction potentially introduces language bias as studies in non-English-speaking countries are more likely to be published in an international English-language journal when significant results are found (Egger et al., 1997; Moher et al., 1996). However, the problem of language bias has reduced in the recent years due to a shift toward publications in the English language (Galandi, Schwarzer \& Antes, 2006). ${ }^{6}$ Furthermore, we only consider empirical articles published in academic journals and exclude qualitative research methods based on interviews, case studies or conceptual work. This provides us with a better comparable body of research, which improves the quality of our systematic literature review. Qualitative research, such as case studies, however, can provide useful insights if one

${ }^{6}$ As can be seen in Appendix 2.1, the majority of the records we consider for our review have been published after 2000 and we therefore consider the problem of language bias to be minimal. 
wants to learn more about the precise discrepancies between graduates' attributes and employers' needs in a specific sector (see e.g. Nair et al., 2009). Finally, given that we explore whether horizontal mismatch contributes to an inefficient allocation of skills in the labour market, we restrict our search to studies focusing on horizontal mismatch. Therefore, we exclude studies that concentrate on other types of mismatch such as under-education and over-education, as these do not answer our main research question and have already been well-documented in other reviews (e.g. Groot \& Maassen van den Brink, 2000; Hartog, 2000).

We performed a computerized systematic search using a wide range of search terms or keywords, namely, 'fit', 'match' or 'mismatch', combined with 'college', 'education', 'major', 'program', 'programme' or 'study' and 'employment', ‘job', 'labor', 'labour', 'occupation' or 'work' and 'field' (see Appendix 2.2 for the exact combination of search terms). The search was conducted in the following electronic databases: ERIC, EconLit and SocINDEX. ERIC is used as the main search engine as it is the largest education database worldwide. EconLit and SocINDEX were used in order to add potentially missing articles to our search results. Figure 2.1 provides an overview of the selection process of relevant studies.

ERIC initially provides 424 studies that were published between January 1995 and December 2015, whereas EconLit and SocINDEX provide us with 99 and 237 potential records, respectively. Excluding the duplicated, non-peer-reviewed, non-English and non-Dutch records leaves us with 378 studies. Consequently, the studies were sorted based on the title and abstract which further allowed us to exclude 354 studies that did not meet our inclusion criteria. Reading the articles' full text, we keep 24 relevant papers.

The papers meeting the inclusion criteria were coded along a variety of dimensions. First, we recorded how horizontal mismatch was being measured and which variables were included in the analyses as explanatory or outcome variable. The data that were extracted also included the year of publication, the number of countries included, the type of data, the year of data collection, the research method and the sample size. I performed the search and each included article was read and coded independently by all authors. Discrepancies between the obtained results were discussed until agreement was reached among the authors. We did not undertake a formal quality analysis due to the methodological diversity of the retrieved articles. Instead, we included a qualitative discussion of method issues when it was considered relevant. 
Chapter 2

\section{Figure 2.1: Selection process}

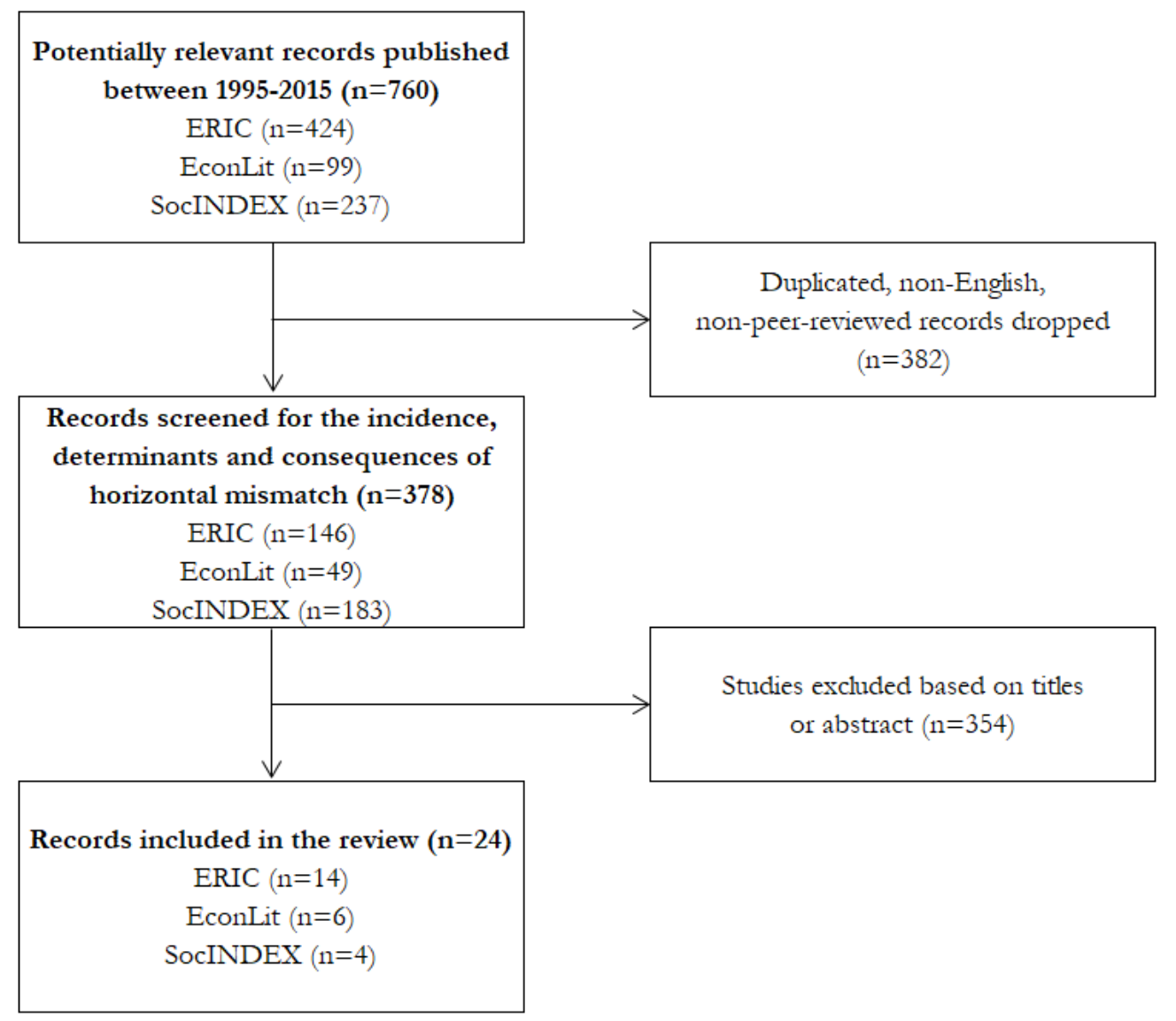

Table 2.1 presents the selected studies and provides an overview of the data that were extracted. Most studies included in our review are correlational and make use of crosssectional data, whereas no experimental studies were found. Hence, the studies under review do not provide any causal evidence on the relation between horizontal mismatch and its determinants and consequences. The nature of correlational studies is subject to several limitations. Outcomes that are associated with horizontal mismatch are not necessarily caused by the acquired field degree as students select themselves into fields. Moreover, the skills and knowledge that workers possess vary across graduates with the same educational background, but are often unobserved. Nonetheless, correlational studies can still be informative provided that field degrees still capture a substantial part of the skills that graduates have acquired through formal education. 
Table 2.1: General description of publications included in the review

\begin{tabular}{|c|c|c|c|}
\hline $\begin{array}{l}\text { Classification } \\
\text { category }\end{array}$ & Sub-categories & $\mathrm{N}$ & Reference index in Appendix 2.1 \\
\hline \multirow[t]{4}{*}{ Year of publication } & $1995-2000$ & 1 & 1 \\
\hline & $2001-2005$ & 3 & $2,3,4$ \\
\hline & 2006-2010 & 8 & $5,6,7,8,9,10,11,12$ \\
\hline & $2011-2015$ & 12 & $\begin{array}{l}13,14,15,16,17,18,19,20,21,22, \\
23,24\end{array}$ \\
\hline \multirow{5}{*}{$\begin{array}{l}\text { Number of } \\
\text { countries included } \\
\text { in the study } \\
\text { Type of data }\end{array}$} & Single country & 18 & $\begin{array}{l}1,2,3,5,6,7,8,10,11,12,13,14,15, \\
17,18,19,23,24\end{array}$ \\
\hline & Several countries & 6 & $4,9,16,20,21,22$ \\
\hline & Cross sectional data & 18 & $\begin{array}{l}1,2,4,5,6,9,10,11,13,16,17,18 \\
19,20,21,22,23,24\end{array}$ \\
\hline & Time series data & 4 & $3,7,8,15$ \\
\hline & Panel data & 2 & 12,14 \\
\hline \multirow{6}{*}{$\begin{array}{l}\text { Year of data } \\
\text { collection }\end{array}$} & 1980-1985 & 2 & 1,12 \\
\hline & 1986-1990 & 4 & $1,9,12,16$ \\
\hline & 1991-1995 & 5 & $3,5,6,12,14$ \\
\hline & $1996-2000$ & 5 & $2,4,7,10,14$ \\
\hline & $2001-2005$ & 8 & $7,8,11,13,14,17,19,20$ \\
\hline & 2006-2011 & 8 & $8,14,15,18,21,22,23,24$ \\
\hline \multirow{3}{*}{ Type of study } & Descriptive & 1 & 8 \\
\hline & Correlational & 23 & $\begin{array}{l}1,2,3,4,5,6,7,9,10,11,12,13,14 \\
15,16,17,18,19,20,21,22,23,24\end{array}$ \\
\hline & Causal/experimental & 0 & \\
\hline \multirow[t]{7}{*}{ Sample size } & Less than 1,000 & 2 & 15,18 \\
\hline & $1,000-2,000$ & 1 & 24 \\
\hline & $2,000-3,000$ & 3 & $1,2,12$ \\
\hline & $3,000-4,000$ & 2 & 9,10 \\
\hline & $4,000-5,000$ & 0 & \\
\hline & $5,000-10,000$ & 5 & $3,17,20,22,23$ \\
\hline & Greater than 10,000 & 11 & $4,5,6,7,8,11,13,14,16,19,21$ \\
\hline \multirow{12}{*}{$\begin{array}{l}\text { Determinants } \\
\text { subject to } \\
\text { examination }\end{array}$} & $\begin{array}{l}\text { Education related determinants - } \\
\text { individual level }\end{array}$ & & \\
\hline & Field-of-study & 9 & $4,5,6,7,14,15,17,18,22$ \\
\hline & Level of education & 8 & $4,5,6,7,15,17,18,19$ \\
\hline & Attending vocational education & 2 & 18,21 \\
\hline & Type of vocational education & 2 & 1,4 \\
\hline & Work experience during studies & 2 & 18,22 \\
\hline & $\begin{array}{l}\text { Major activity before programme } \\
\text { enrolment }\end{array}$ & 1 & 17 \\
\hline & Time devoted to studies & 2 & 15,17 \\
\hline & $\begin{array}{l}\text { Study programme's prestige } \\
\text { Education related determinants - } \\
\text { country level }\end{array}$ & 1 & 18 \\
\hline & Timing of academic specialization & 1 & 16 \\
\hline & $\begin{array}{l}\text { Vocational orientation education } \\
\text { system }\end{array}$ & 1 & 21 \\
\hline & Strength institutional linkages & 1 & 21 \\
\hline
\end{tabular}


Chapter 2

Table 2.1 (continued)

\begin{tabular}{|c|c|c|c|}
\hline $\begin{array}{l}\begin{array}{l}\text { Classification } \\
\text { category }\end{array} \\
\end{array}$ & Sub-categories & 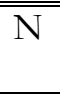 & "Reference index in Appendix 2.1 \\
\hline & Labour market related determinants & & \\
\hline & State economy & & \\
\hline & Job search duration & 2 & 4,7 \\
\hline & Opportunity structure & 1 & 22 \\
\hline & & 1 & 1 \\
\hline & Job related determinants & & \\
\hline & Job tenure & 3 & $1,4,18$ \\
\hline & Occupational group & 3 & $1,15,19$ \\
\hline & Type of employment contract & 3 & $4,17,22$ \\
\hline & Sector & 2 & 4,14 \\
\hline & Firm size & 3 & $1,4,18$ \\
\hline & Occupational 'cultures of training' & 1 & 1 \\
\hline & Method to obtain employment & 1 & 17 \\
\hline & Individual related determinants & & \\
\hline & Gender & 11 & $1,4,5,6,7,14,15,17,18,19,22$ \\
\hline & Age & 10 & $1,4,5,6,7,14,17,18,19,22$ \\
\hline & Ethnicity & 5 & $5,6,7,17,19$ \\
\hline & Disability & 3 & $5,6,14$ \\
\hline & Marital status & 3 & $5,6,19$ \\
\hline & Job mobility & 2 & 7,22 \\
\hline & Parental education & 2 & 17,22 \\
\hline & Ability & 2 & 17,18 \\
\hline \multirow[t]{6}{*}{$\begin{array}{l}\text { Effects subject to } \\
\text { examination }\end{array}$} & Wage & 13 & $\begin{array}{l}1,2,3,5,6,9,11,12,13,14,19,23, \\
24\end{array}$ \\
\hline & On-the-job search & 5 & $2,4,9,13,24$ \\
\hline & Occupational status & 1 & 4 \\
\hline & Training participation & 1 & 4 \\
\hline & Job satisfaction & 5 & $2,9,13,19,24$ \\
\hline & Field-of-study regret & 2 & 10,20 \\
\hline
\end{tabular}

Notes: studies can fall into more than one subcategory. a. An overview of the examined countries can be found in Appendix 2.1. The numbers in the last column of the table refer to 1 of the 24 studies for which more detailed information is provided in Appendix 2.1.

\subsection{Measurement of horizontal mismatch}

Horizontal mismatch is usually defined by comparing an employee's attended field-ofstudy with the field required for the job the employee holds. Most of the academic studies on mismatch consider educational attainment as a proxy for the knowledge and skills a worker possesses. However, the skills that are being taught in formal education often only partially overlap with the knowledge and skills that are required in the job (Allen \& Van der Velden, 2001). Nevertheless, if skill adjustments are considered as coming with recent graduates to the job, formal education is expected to provide graduates who employers would like to hire (Rogerson, Shimer \& Wright, 2005). This suggests that it would be fruitful to investigate the extent to which mismatches between the attended field-of-study and the job are present in the labour market and what its determinants and consequences are. 
The literature on horizontal mismatch distinguishes between 'subjective' and 'objective' definitions. The subjective approach measures the educational requirements for a job based on employees' self-report. The objective method, on the other hand, determines the educational requirements for an occupation using an expert or by assigning occupational codes for statistical purposes to educational fields.

\subsubsection{Subjective measure}

In many subjective specifications of horizontal mismatch, the respondent specifies the job requirements in terms of the field-of-study. For instance, Kucel and Vilalta-Bufí (2013) classified employees as horizontally matched if (s)he reported that exclusively their own field or a related field was appropriate for the job, whilst employees were classified as horizontally mismatched when a completely different field or no particular field was most appropriate for the job. Other studies based their definition on the degree to which employees perceive a fit between their field degree and their current job. An example of a question measuring this degree is 'Thinking about the relationship between your work and your education, to what extent is your work related to your doctoral degree? Was it closely related, somewhat related, or not related?' (see e.g. Bender \& Heywood, 2011; Bender \& Roche, 2013; Robst, 2007a, 2007b).

\subsubsection{Objective measure}

In addition to employees' self-assessment, several studies used an objective indicator of horizontal mismatch. Béduwé and Giret (2011) derived horizontal mismatch measures from a normative correspondence table established by experts. This table categorizes the distinct areas of vocational knowledge into 25 groups to which both educational qualifications and occupations can belong. When the knowledge group of the field degree and occupation do not correspond, there is 'horizontal mismatch'. Other studies use the International Standard Classification of Occupations to assign occupational codes to a field-of-study (e.g. Wolbers, 2003). The matching process is based on the extent to which the skills acquired through a specific field-of-study correspond to the job requirements. Accordingly, a discrepancy between the skills obtained in initial education and the skills needed on the job is considered as horizontal mismatch.

The potential advantage of the subjective approach is that it is specifically concerned with the content of the respondent's job and not with any type of aggregate of that occupation. In contrast, the normative correspondence table used by Béduwé and Giret (2011) allows occupations and educational qualifications to be categorized into only 25 groups. Some occupations or educational qualifications will better fit into one of the categories than others. Having too many categories, however, increases the likelihood 
that the combination of jobs and field degrees are defined as mismatched despite a large congruence of skills and knowledge (Malamud, 2011). Therefore, the subjective approach might provide a more valid measure of horizontal mismatch as employees' field degree is directly compared with the content or the educational requirements for the job. A potential disadvantage of the subjective method is that employees' perception of horizontal match is by definition subject to self-report bias. From this perspective, a method such as the normative correspondence table can provide a less biased indicator of horizontal mismatch. Moreover, asking employees whether their field degree was a requirement for the job might also not be the best indicator for horizontal mismatch. Some employers might simply require more general skills that can be obtained through various fields of study. Hence, the validity of these subjective measures can be called into question.

It is noteworthy that horizontal mismatch is being measured in a similar manner across graduates who have acquired different field degrees. While some fields clearly prepare students for specific occupations, such as medicine and law, other fields are more general in nature, like arts. Consequently, some professions require their workers to have attended a specific field that provides students with occupation-specific skills and knowledge, whereas other occupations require graduates to possess more general skills that can be acquired through a variety of study programmes. Therefore, comparing job applicants' acquired field degree to the educational requirements for the jobs can be inappropriate if one wants to reveal skill mismatches, especially if the field-of-study does not prepare students for a specific occupation. We will return to this issue several times in this chapter.

\subsection{Prevalence of horizontal mismatch}

Table 2.2 summarizes the findings of the 20 studies that report the incidence of horizontal mismatch. Not all 24 studies selected for our review estimated the prevalence of horizontal mismatch. The literature identifies at least four ways to measure horizontal mismatch: definition (A) - based on employees' assessment of whether a specific field-ofstudy was required for the job or not; definition (B) - based on employees' assessment of whether their field-of-study is related to or relevant for their current occupation; definition (C) - respondents' assessment of whether or not they have been trained for their current job; and definition (D) - based on an objective evaluation where occupations and educational fields are categorized according to the assumed congruence between the skills acquired through the field degree and the skills needed to perform a specific occupation. 
Table 2.2 shows that there is considerable variation in the mismatch incidence reported by the studies under review. Note that some studies made a distinction between severely mismatched and moderately mismatched employees when reporting the incidence rate of mismatched employees (e.g. Robst, 2007a, 2007b), whereas other studies combined such categories into one (e.g. Allen \& Van der Velden, 2001). The incidence reported by the studies under review vary from 7 to 63 percent. The incidence, however, seems to depend on how horizontal mismatch is specified. For instance, Malamud (2011) found 63 percent of employees in England to be mismatched when using a narrow classification and an incidence rate of 44 percent based on a very broad classification. Whilst the narrow classification allows fields and occupations to be categorized into 42 categories, the very broad classification distinguishes 6 categories. Thus, employees are more likely to be defined as mismatched according to the narrow classification.

On average, studies using definition $A$ find that almost 21 percent of the employees are horizontally mismatched. According to definition B, 21.8 percent of the employees hold a field degree that is either only somewhat relevant or only slightly relevant for the job they hold (column 4). Based on the same definition, 23.3 percent of the employees hold a degree that is either somewhat relevant or completely irrelevant for their job (column 5). One study used definition $C$ and found that 46 percent of the employees are in a job for which they have not been trained. Finally, according to definition D, 22.1 percent of the employees hold an occupation for which their field has some relevance (column 4). Again adopting definition $\mathrm{D}$, column 5 shows that 35.4 percent of the employees are fully mismatched or hold a degree that only has low relevance for their job. Table 2.2 also separately depicts the incidence of horizontal mismatch for men, women, different career stages, countries, different types of employment and for various reasons for accepting horizontal mismatch. We discuss how these variables relate to horizontal mismatch in more detail in the next sections. 
Table 2.2: Incidence of horizontal mismatch

\begin{tabular}{|c|c|c|c|c|c|c|}
\hline $\begin{array}{l}\text { Author (year of } \\
\text { publication) }\end{array}$ & $\begin{array}{l}\text { Country of stuc } \\
\text { and definition }\end{array}$ & & $\begin{array}{l}\text { Year data } \\
\text { collection }\end{array}$ & $\begin{array}{l}\text { Moderately } \\
\text { mismatched } \\
\text { (male/female) }(\%)\end{array}$ & $\begin{array}{l}\text { Severely mismatched (male/female) } \\
(\%)\end{array}$ & $\begin{array}{l}\text { Incidence of horizontal mismatch for } \\
\text { other sample characteristics } \\
\text { (male/female) }(\%)\end{array}$ \\
\hline Witte et al. (1995) & Germany & $\mathrm{C}$ & 1984-1990 & & Not trained for job: $46.35(51.0 / 39.0)$ & \\
\hline Solga et al. (1999) & Germany & $\mathrm{D}$ & $\begin{array}{l}\text { West } \\
\text { Germany: } \\
\text { 1980s } \\
\text { East } \\
\text { Germany: } \\
\text { 1991/1992 }\end{array}$ & & $\begin{array}{l}\text { West Germany } \\
\text {-Apprenticeship in craft/trade } \\
\text { occupations: } 19 \\
\text {-Apprenticeship in commercial } \\
\text { occupations: } 33 \\
\text {-Full time vocational school: } 24 \\
\text {-University education: } 27 \\
\text { East Germany } \\
\text {-Apprenticeship in craft/trade } \\
\text { occupations: } 26 \\
\text {-Apprenticeship in commercial } \\
\text { occupations:36 } \\
\text {-Full time vocational school: } 19 \\
\text {-University: } 18\end{array}$ & \\
\hline Allen et al. (2001) & $\begin{array}{l}\text { The } \\
\text { Netherlands }\end{array}$ & A & 1998 & & $\begin{array}{l}\text { Own/related field not most } \\
\text { appropriate: } \pm 20.0\end{array}$ & \\
\hline $\begin{array}{l}\text { Robst }(2007 a, \\
2007 b, \text { Robst } \\
2008)^{b}\end{array}$ & United States & $\mathrm{B}$ & 1993 & $\begin{array}{l}\text {-Somewhat related: } \\
25.1(28.3 / 20.8) \\
\text {-Somewhat related } \\
\text { among over-educated } \\
\text { workers: }(22.2 / 30.2)\end{array}$ & $\begin{array}{l}\text {-Not related: } 20.1(19.1 / 21.4) \\
\text {-Not related among over-educated } \\
\text { workers: }(25.9 / 23.6)\end{array}$ & $\begin{array}{l}\text { Most important reason for accepting HM } \\
\text { (male/female) }(\%) \text { : } \\
\text {-Pay, promotion: } 32.7 / 18.8 \\
\text {-Working conditions:8.8/11.1 } \\
\text {-Job location: } 4.3 / 3.5 \\
\text {-Change career interests: } 19.0 / 19.3 \\
\text {-Family-related: } 5.9 / 18.1 \\
\text {-Job in field degree unavailable: } \\
16.0 / 16.3\end{array}$ \\
\hline $\begin{array}{l}\text { Hensen et al. } \\
\text { (2009) }\end{array}$ & $\begin{array}{l}\text { The } \\
\text { Netherlands }\end{array}$ & $\mathrm{B}$ & 1996-2001 & & $\begin{array}{l}\text { Own/related field not most } \\
\text { appropriate: } 30.0(29.0 / 30.0)\end{array}$ & \\
\hline Mora (2010) & Spain & A & 2000 & & No specific field required: 18.95 & \\
\hline
\end{tabular}

Netherland

Spain appropriate: $30.0(29.0 / 30.0)$

No specific field required: 18.95 
Table 2.2 (continued)

\begin{tabular}{|c|c|c|c|c|c|c|}
\hline $\begin{array}{l}\text { Author (year of } \\
\text { publication) }\end{array}$ & \multicolumn{2}{|c|}{$\begin{array}{l}\text { Country of } \\
\text { study } \\
\text { and definition }{ }^{a}\end{array}$} & $\begin{array}{l}\text { Year data } \\
\text { collection }\end{array}$ & $\begin{array}{l}\text { Moderately } \\
\text { mismatched } \\
(\text { male/female }) \\
(\%)\end{array}$ & "Severely mismatched (male/female) $(\%)$ & $\begin{array}{l}\text { Incidence of horizontal mismatch for other } \\
\text { sample characteristics (male/female) }(\%)\end{array}$ \\
\hline $\begin{array}{l}\text { Nordin et al. } \\
\text { (2010) }\end{array}$ & Sweden & $\mathrm{D}$ & 2003 & $\begin{array}{l}\text { Weak match: } \\
11.67(18.0 / 8.0)\end{array}$ & Mismatch: $19.2(23.0 / 17.0)$ & \\
\hline $\begin{array}{l}\text { Yakusheva } \\
(2010)\end{array}$ & $\begin{array}{l}\text { United } \\
\text { States }\end{array}$ & $\mathrm{D}$ & $\begin{array}{l}\text { 1980, 1984, } \\
1986,1992\end{array}$ & $\begin{array}{l}\text { Field knowledge } \\
\text { has medium } \\
\text { relevance for job: } \\
32.45\end{array}$ & " low relevance ": 14.55 & \\
\hline $\begin{array}{l}\text { Béduwé et al. } \\
\text { (2011) }\end{array}$ & France & $\mathrm{D}$ & 2001 & & 59.0 & $\begin{array}{l}\text {-No VM but HM: } 30 \\
\text {-VM and HM: } 29\end{array}$ \\
\hline $\begin{array}{l}\text { Bender et al. } \\
\text { (2011) }\end{array}$ & $\begin{array}{l}\text { United } \\
\text { States }\end{array}$ & $\mathrm{B}$ & $\begin{array}{l}\text { 1993, 1995, } \\
\text { 1997, 1999, } \\
2001,2003, \\
2006\end{array}$ & $\begin{array}{l}\text { Somewhat } \\
\text { matched: } 24.7 \\
(25.5 / 22.5)\end{array}$ & Severely mismatched: $8.0(8.3 / 7.0)$ & $\begin{array}{l}\text {-Somewhat matched in early career: } 22.8 \\
\text {-" in middle ": } 25.3 \\
\text {-" in late ": } 26.8 \\
\text {-Severely mismatched in early career: } 5.9 \\
\text {-" in middle ": } 8.5 \\
\text {-" in late ": } 10.2 \\
\text { Main reason for HM (early career/ late career stage): } \\
\text {-Pay, promotion: } 22.1 / 19.3 \\
\text {-Working conditions: } 5.1 / 4.9 \\
\text {-Job location: } 4.6 / 5.2 \\
\text {-Change career interests: } 25.6 / 38.9 \\
\text {-Family-related: } 8.1 / 4.6 \\
\text {-Job in field degree unavailable: } 26.7 / 18.3\end{array}$ \\
\hline Farooq (2011) & Pakistan & $\mathrm{B}$ & $\begin{array}{l}2006 / 2007 \\
2008 / 2009\end{array}$ & $\begin{array}{l}\text {-Slightly relevant: } \\
13.8(18.5 / 12.9)\end{array}$ & -Irrelevant: 11.3 (14.8/10.6) & \\
\hline $\begin{array}{l}\text { Malamud (2010, } \\
\text { 2011) b }\end{array}$ & $\begin{array}{l}\text { England } \\
\text { and } \\
\text { Scotland }\end{array}$ & $\mathrm{D}^{\mathrm{c}}$ & 2011 & & $\begin{array}{l}\text { Overall average: } 45.17 \\
\text {-Very broad classification England: } 44.0 \\
\text {-Broad classification England: } 50.0 \\
\text {-Narrow classification England: } 63.0 \\
\text {-Very broad classification Scotland: } 29.0 \\
\text {-Broad classification Scotland: } 34.0 \\
\text {-Narrow classification Scotland: } 51.0 \\
\end{array}$ & \\
\hline
\end{tabular}


Table 2.2 (continued)

\begin{tabular}{|c|c|c|c|c|c|c|}
\hline $\begin{array}{l}\text { Author (year of } \\
\text { publication) }\end{array}$ & $\begin{array}{l}\text { Country of stud } \\
\text { and definition }\end{array}$ & & $\begin{array}{l}\text { Year data } \\
\text { collection }\end{array}$ & $\begin{array}{l}\text { Moderately mismatched } \\
\text { (male/female) }(\%)\end{array}$ & Severely mismatched (male/female) (\%) & $\begin{array}{l}\text { Incidence of horizontal } \\
\text { mismatch for other sample } \\
\text { characteristics } \\
\text { (male/female) }(\%)\end{array}$ \\
\hline $\begin{array}{l}\text { Boudarbat et al. } \\
(2012)\end{array}$ & Canada & $\mathrm{B}$ & 2005 & & Somewhat/not closely related: 35.1 & \\
\hline Kucel et al. (2012) & Poland & A & 2008 & & Other/ no specific field required: 18.0 & \\
\hline Kucel et al. (2013) & $\begin{array}{l}\text { Spain and The } \\
\text { Netherlands }\end{array}$ & A & 2005 & & $\begin{array}{l}\text { Other/ no specific field required: } \\
\text {-Spain: } 27.0 \\
\text {-Netherlands: } 20.0\end{array}$ & \\
\hline $\begin{array}{l}\text { Bender et al. } \\
(2013)\end{array}$ & United States & $\mathrm{B}$ & 2003 & $\begin{array}{l}\text { Overall weighted average: } \\
23.64 \\
\text {-Moderately mismatched } \\
\text { wage/salary employees: } \\
23.7(25.5 / 21.0) \\
\text {-Moderately mismatched } \\
\text { self-employed: } 23.3 \\
(24.0 / 21.5)\end{array}$ & $\begin{array}{l}\text { Overall weighted average: } 14.2 \\
\text {-Severely mismatched wage/salary } \\
\text { employees: } 13.3(13.2 / 13.5) \\
\text {-Severely mismatched self-employed: } 19.4 \\
(17.5 / 24.4)\end{array}$ & \\
\hline Levels et al. (2014) & 20 countries $^{\mathrm{d}}$ & $\mathrm{D}$ & & & 38.8 & \\
\hline Zhu (2014) & China & $\mathrm{B}$ & 2008 & & Not related: $28.16(27.2 / 29.7)$ & \\
\hline $\begin{array}{l}\text { Shevchuk et al. } \\
\text { (2015) }\end{array}$ & Russia & $\mathrm{B}$ & 2011 & & $\begin{array}{l}\text { Job fully/mostly mismatches } 39.31 \\
(43.4 / 35.6)\end{array}$ & \\
\hline $\begin{array}{l}\text { Verhaest et al. } \\
\text { (2017) }\end{array}$ & 18 countries & $\mathrm{B}$ & $\begin{array}{l}2005 \text { and } \\
2008\end{array}$ & & & $\begin{array}{l}\text {-No VM but HM: } 10.4 \\
\text {-VM and HM: } 7.5\end{array}$ \\
\hline
\end{tabular}

\footnotetext{
Notes: A. based on self-report of whether a specific field of education was required for the job B. based on respondents' assessment of the extent to which their attended field of is related to or relevant for their current occupation C. respondents' assessment of whether or not they have been trained for their current employment D. objective measure. b. Note that these are two separate studies using the same dataset, we therefore we report the incidence of horizontal mismatch found in these studies once. c. Occupations and fields of study are categorized according to three gradations of classification: narrow (42 categories), broad (12 categories) and very broad (6 categories). An employee is defined to be horizontally mismatched when the field and occupation fall into different categories. Most analyses are based on the broad classification, but are robust to alternative classifications. d. Austria, Belgium, Czech Republic, Germany, Denmark, Spain, Finland, France, Greece, Hungary, Ireland, Italy, Luxembourg, the Netherlands, Norway, Poland, Sweden, Slovenia, Slovak Republic and the UK. e. The 18 countries comprise Austria, Belgium (Flanders), Czech Republic, Estonia, Finland, France, Germany, Hungary, Italy, Japan, the Netherlands, Norway, Poland, Portugal, Slovakia, Spain, Switzerland and the U.K.
} 


\subsection{Determinants of horizontal mismatch}

In this section, we report which variables were considered potential determinants of horizontal mismatch in the studies under review and whether a positive, negative or no relationship was found. The findings are summarized in Table 2.3-2.7 and are categorized into education-, labour market-, job- and individual related determinants. We limit our discussion to those determinants that have been investigated by at least two studies. The determinants that were subject to examination in only one study can be found in Appendix 2.1.

\subsubsection{Education-related determinants}

Several factors predicting horizontal mismatch relate to the education the individual has received. The education-related factors can be classified at two levels: the individual level and the country level. With education-related determinants on the individual level, we refer to factors that can be considered an individual's choice such as the field and level of education. In contrast, education-related determinants on the country level are rather exogenous to the individual and may, for instance, concern the vocational orientation of a country's education system.

\section{Education-related determinants at the individual level}

Table 2.3 summarizes the findings for education-related determinants at the individual level. The prevalence of horizontal mismatch among graduates depends among other things on the characteristics of the field-of-study. With respect to the field degree, the highest mismatch rates are found among liberal arts graduates, whilst the mismatch rates are lowest for graduates from health- related fields (Robst, 2007a; Wolbers, 2003). Health-related fields mainly provide students with occupation-specific skills which reduces the likelihood that graduates search for jobs outside their own field (Wolbers, 2003). The probability that horizontal mismatch occurs across the career stage also depends on the attended field degree. This can be attributed to the pace of human capital depreciation associated with the field-of-study (Bender \& Heywood, 2011). For instance, science- and engineer-based careers are more sensitive to mismatch due to the high frequency of technological changes which induce rapidly changing skill requirements (Bender \& Heywood, 2011). 
Table 2.3: Education-related determinants (individual level) of horizontal mismatch (= treated as the outcome variable)

Education-related determinants - Individual level

\begin{tabular}{|c|c|c|c|c|c|c|c|c|c|c|}
\hline $\begin{array}{l}\text { Author } \\
\text { (year of } \\
\text { publication) }\end{array}$ & $\begin{array}{l}\text { Country of stu } \\
\text { and definition } \\
\text { used }^{\mathrm{a}}\end{array}$ & & $\begin{array}{l}\text { Field- } \\
\text { of- } \\
\text { study }\end{array}$ & $\begin{array}{l}\text { Level } \\
\text { of } \\
\text { study }\end{array}$ & $\begin{array}{l}\text { Vocational } \\
\text { study/ } \\
\text { vocational } \\
\text { orientation }\end{array}$ & $\begin{array}{l}\text { Type of vocational } \\
\text { education (men/women) }\end{array}$ & $\begin{array}{l}\text { Work } \\
\text { experience } \\
\text { during studies } \\
\text { (ref. cat.=no } \\
\text { work } \\
\text { experience) }\end{array}$ & $\begin{array}{l}\text { Major activity } \\
\text { before entering } \\
\text { university (ref. } \\
\text { cat.=not } \\
\text { working/ } \\
\text { studying) }\end{array}$ & $\begin{array}{l}\text { Time } \\
\text { devoted to } \\
\text { studies } \\
\text { (ref. } \\
\text { cat.=full- } \\
\text { time) }\end{array}$ & $\begin{array}{l}\text { Study pro- } \\
\text { gramme's } \\
\text { prestige/ } \\
\text { selectivity }\end{array}$ \\
\hline $\begin{array}{l}\text { Witte et al. } \\
(1995)\end{array}$ & Germany & $\mathrm{C}$ & & & & $\begin{array}{l}\text { Ref. cat=school-based } \\
\text { vocational education } \\
\text {-Industrial } \\
\text { apprenticeship: +/n.e. } \\
\text {-Commercial } \\
\text { apprenticeship: +/n.e. }\end{array}$ & & & & \\
\hline $\begin{array}{l}\text { Wolbers } \\
(2003)\end{array}$ & $\begin{array}{l}13 \\
\text { countries }^{b}\end{array}$ & $\mathrm{D}$ & s.e. & - & & $\begin{array}{l}\text { Ref. cat. }=\text { no vocational } \\
\text { educ.: n.e. }\end{array}$ & & & & \\
\hline Robst (2007a) & United States & $\mathrm{B}$ & s.e. & - & & & & & & \\
\hline $\begin{array}{l}\text { Hensen et al. } \\
(2009)\end{array}$ & $\begin{array}{l}\text { The } \\
\text { Netherlands }\end{array}$ & B & s.e. & - & & & & & & \\
\hline $\begin{array}{l}\text { Bender et al. } \\
(2011)\end{array}$ & United States & $\mathrm{B}$ & s.e. & & & & & & & \\
\hline Farooq (2011) & Pakistan & B & s.e. & n.e. & - & & & & $\begin{array}{l}\text { Part- } \\
\text { time:+ }\end{array}$ & \\
\hline Klein (2011) & Germany & $\mathrm{D}$ & s.e. & & & & & & & $\begin{array}{l}\text { Selectivity: } \\
\text { n.e. }\end{array}$ \\
\hline $\begin{array}{l}\text { Malamud } \\
\text { (2011) }\end{array}$ & $\begin{array}{l}\text { England and } \\
\text { Scotland }\end{array}$ & $\mathrm{D}$ & s.e. & & & & & & & \\
\hline $\begin{array}{l}\text { Boudarbat et } \\
\text { al. }(2012)\end{array}$ & Canada & $\mathrm{B}$ & s.e. & - & & & & $\begin{array}{l}\text {-Studying: + } \\
\text {-Working: + } \\
\text {-Studying and } \\
\text { working: + }\end{array}$ & $\begin{array}{l}\text {-Part- } \\
\text { time:+ } \\
\text {-Mix part- } \\
\text { time and } \\
\text { full-time:+ }\end{array}$ & \\
\hline
\end{tabular}


Table 2.3 (continued)

\begin{tabular}{|c|c|c|c|c|c|c|c|c|c|c|}
\hline \multirow[b]{2}{*}{$\begin{array}{l}\text { Author } \\
\text { (year of } \\
\text { publication) }\end{array}$} & \multirow[b]{2}{*}{$\begin{array}{l}\text { Country of } \\
\text { study } \\
\text { and } \\
\text { definition }^{\text {used }}\end{array}$} & & \multicolumn{8}{|c|}{ Education-related determinants - Individual level } \\
\hline & & & $\begin{array}{l}\text { Field- } \\
\text { of- } \\
\text { study }\end{array}$ & $\begin{array}{l}\text { Level of } \\
\text { study }\end{array}$ & $\begin{array}{l}\text { Vocational } \\
\text { study/ } \\
\text { vocational } \\
\text { orientation }\end{array}$ & $\begin{array}{l}\text { Work experience } \\
\text { during studies (ref. } \\
\text { cat.=no work } \\
\text { experience) }\end{array}$ & $\begin{array}{l}\text { Major activity } \\
\text { before entering } \\
\text { university (ref. } \\
\text { cat.=not } \\
\text { working/ } \\
\text { studying) }\end{array}$ & $\begin{array}{l}\text { Time } \\
\text { devoted to } \\
\text { studies } \\
\text { (ref. } \\
\text { cat.=full- } \\
\text { time) }\end{array}$ & $\begin{array}{l}\text { Study pro- } \\
\text { gramme's } \\
\text { prestige/ } \\
\text { selectivity }\end{array}$ & $\begin{array}{l}\text { Study } \\
\text { programme } \\
\text { provides } \\
\text { access to } \mathrm{PhD}\end{array}$ \\
\hline $\begin{array}{l}\text { Kucel et al. } \\
(2012)\end{array}$ & Poland & $\mathrm{A}$ & s.e. & n.e. & n.e. & Internship: n.e. & & & $\begin{array}{l}\text {-Employers } \\
\text { familiar: - } \\
\text {-Prestigious: - }\end{array}$ & \\
\hline $\begin{array}{l}\text { Bender et al. } \\
(2013)\end{array}$ & United States & $\mathrm{B}$ & & - & & & & & & \\
\hline $\begin{array}{l}\text { Levels et al. } \\
(2014)\end{array}$ & 20 countries $^{c}$ & $\mathrm{D}$ & & & - & & & & & \\
\hline Robert (2014) & $\begin{array}{l}\text { Hungary, } \\
\text { Poland, } \\
\text { Lithuania and } \\
\text { Slovenia }\end{array}$ & A & s.e. & & & $\begin{array}{l}\text {-Study-related work } \\
\text { experience: - } \\
\text {-Not study-related } \\
\text { work experience: + }\end{array}$ & & & & \\
\hline $\begin{array}{l}\text { Verhaest et al. } \\
(2017)\end{array}$ & 18 countries $^{d}$ & $\mathrm{~B}$ & s.e. & & $\begin{array}{l}\text {-If HM: - } \\
\text {-If HM+VM: } \\
\text { n.e. }\end{array}$ & & & & $\begin{array}{l}\text { Quality/ } \\
\text { selectivity: - }\end{array}$ & $\begin{array}{l}\text { If } \mathrm{HM}:+ \\
\text { If } \mathrm{HM}+\mathrm{VM}: \\
\text { n.e. }\end{array}$ \\
\hline \multicolumn{11}{|c|}{$\begin{array}{l}\text { Notes: + indicates a positive relation between horizontal mismatch and the determinant, - indicates a negative relation, and n.e. indicates that no effect was found. } \\
\text { a. Definition of horizontal mismatch: A. based on self-report on whether a specific field of education was required for the job B. based on respondents' assessment } \\
\text { of the extent to which their current occupation is related to their attended field of education C. based on respondents' assessment of whether or not they have been } \\
\text { trained for their current employment D. objective measure. b. The } 13 \text { countries comprise Austria, Belgium, Denmark, Spain, Finland, France, Greece, Hungary, } \\
\text { Italy, Luxembourg, The Netherlands, Sweden and Slovenia. c. The } 20 \text { countries comprise Austria, Belgium, Czech Republic, Germany, Denmark, Spain, Finland, } \\
\text { France, Greece, Hungary, Ireland, Italy, Luxembourg, the Netherlands, Norway, Poland, Sweden, Slovenia, Slovak Republic and the UK. d. The } 18 \text { countries } \\
\text { comprise Austria, Belgium (Flanders), Czech Republic, Estonia, Finland, France, Germany, Hungary, Italy, Japan, the Netherlands, Norway, Poland, Portugal, } \\
\text { Slovakia, Spain, Switzerland and the U.K. }\end{array}$} \\
\hline
\end{tabular}




\section{Education-related determinants at the country level}

Three characteristics of a country's education system were identified that determine horizontal mismatch: the timing of academic specialization, the vocational orientation and the strength of institutional linkages (Table 2.4). Regarding the timing of academic specialization, Malamud (2011) found that graduates who attended the Scottish education system (which is characterized by late specialization) are less likely to hold a job unrelated to the field-of-study compared to graduates from the English education system in which students specialize early. A possible explanation is that later specialization offers students more time to acquire valuable information about their preferences and abilities by taking courses in different fields. Moreover, later specialization conceivably provides students more insight into the probability of obtaining a field-related occupation given the acquisition of a specific field degree.

Also, the extent to which an education system is vocationally oriented is strongly country dependent. Wolbers (2003) defined countries as being more vocationally oriented when the share of upper secondary education students, who are enrolled in school-based or apprentice-type of vocational education, is larger. Although the results were insignificant, graduates were found to be more often mismatched in vocationally oriented countries. Levels, Van der Velden and Di Stasio (2014) also found that the horizontal mismatch incidence is greater in countries with a strong vocational orientation. Arguably, competition between graduates with a vocational degree is fiercer in countries with a large share of vocationally educated employees. However, the relation between horizontal mismatch and a vocationally oriented education system can be positive in countries with strong institutional linkages (Levels et al., 2014). The strength of institutional linkages is reflected by the share of vocational education that is organized as a combination of schoolbased education and training at the workplace (Breen, 2005). Countries with strong institutional linkages provide employers an opportunity to teach students skills that are required by existing jobs (Andersen \& Van de Werfhorst, 2010). Moreover, strong institutional linkages allow employers to design jobs in a way such that it meets the expected skills of vocational graduates.

This section has discussed education-related determinants of mismatch. What can be noticed is that several education-related determinants of mismatch share similar properties. The field and level of education, having attended vocational education, the vocational orientation of a country's education system and the strength of institutional linkages within a country all determine the degree to which graduates acquire occupationspecific or general skills. Graduates who predominantly obtained occupation-specific skills are more likely to end up in a job that is closely related to their field degree. 
Table 2.4: Education-related determinants (country level) of horizontal mismatch (=treated as the outcome variable)

\begin{tabular}{|c|c|c|c|c|c|c|}
\hline & & & \multicolumn{4}{|c|}{ Education-related determinants - Country level } \\
\hline $\begin{array}{l}\text { Author } \\
\text { (year of publication) }\end{array}$ & $\begin{array}{l}\text { Country of study } \\
\text { and definition used }\end{array}$ & & $\begin{array}{l}\text { Time of academic } \\
\text { specialization (ref. } \\
\text { cat.=early specialization) }\end{array}$ & $\begin{array}{l}\text { Vocational orientation } \\
\text { education system }\end{array}$ & $\begin{array}{l}\text { Strength } \\
\text { institutional } \\
\text { linkages }\end{array}$ & $\begin{array}{l}\text { Quality and } \\
\text { selectivity higher } \\
\text { education system }\end{array}$ \\
\hline Wolbers (2003) & $\begin{array}{l}13 \\
\text { countries }^{b}\end{array}$ & $\mathrm{D}$ & & $\begin{array}{l}\text {-Share of upper secondary } \\
\text { students in school-based } \\
\text { vocational education: + } \\
\text {-" in apprenticeship type } \\
\text { vocational education: n.e. }\end{array}$ & 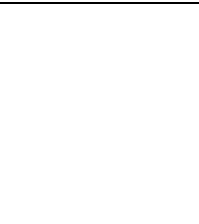 & \\
\hline Malamud (2011) & England and Scotland & $\mathrm{D}$ & Late specialization: - & & & \\
\hline Levels et al. (2014) & 20 countries $^{c}$ & $\mathrm{D}$ & & $\begin{array}{l}+ \\
\underline{\text { Interaction vocational }} \\
\text { orientation } \times \text { vocational } \\
\text { education: n.e. }\end{array}$ & $\begin{array}{l}\text { Interaction } \\
\underline{\text { institutional }} \\
\underline{\text { linkages } \times} \\
\underline{\text { vocational }} \\
\text { education:- }\end{array}$ & \\
\hline
\end{tabular}

$\begin{array}{lll}{\text { Verhaest et al. (2017) } 18 \text { countries }^{\mathrm{d}}} \quad \text { B } & \text { If HM: n.e. } \\ & & \text { If HM+VM: n.e. }\end{array}$

Notes: + indicates a positive relation between horizontal mismatch and the determinant, - indicates a negative relation, and n.e. indicates that no effect was found. a. Definition of horizontal mismatch: A. based on self-report on whether a specific field of education was required for the job B. based on respondents' assessment of the extent to which their current occupation is related to their attended field of education C. based on respondents' assessment of whether or not they have been trained for their current employment D. objective measure. b. The 13 countries comprise Austria, Belgium, Denmark, Spain, Finland, France, Greece, Hungary, Italy, Luxembourg, The Netherlands, Sweden and Slovenia. c. The 20 countries comprise Austria, Belgium, Czech Republic, Germany, Denmark, Spain, Finland, France, Greece, Hungary, Ireland, Italy, Luxembourg, the Netherlands, Norway, Poland, Sweden, Slovenia, Slovak Republic and the UK. d. The 18 countries comprise Austria, Belgium (Flanders), Czech Republic, Estonia, Finland, France, Germany, Hungary, Italy, Japan, the Netherlands, Norway, Poland, Portugal,

Slovakia, Spain, Switzerland and the U.K. 
Although graduates who mainly acquired general skills are more likely to be horizontally mismatched according to the definitions identified in the literature, their skills are valued in a wider variety of jobs. The degree to which horizontal mismatch among graduates with general education is accompanied by skill-underutilization might therefore be smaller than most definitions actually suggest. According to the human capital theory, general skills increase workers' productivity in a wider range of occupations than specific skills (Becker, 1994). In fact, as we will point out later in this chapter, the wage penalties incurred by employees who received general education are less severe as opposed to those who received more occupation-specific education.

\subsubsection{Labour market-related determinants}

Once students complete formal education, labour market conditions influence graduates' chances of finding a matching job (Table 2.5). Graduates who face an economic recession upon labour market entry adjust their goals and are more likely to accept a job that does not match their field-of-study (Wolbers, 2003). Hensen et al. (2009) did not find a relation between the regional unemployment rate and horizontal mismatch. Another measure for the state of the economy is the opportunity structure. The opportunity structure refers to the number and type of available vacancies and how well an employee's and other potential job candidates' skills match the requirements for a job (Witte \& Kalleberg, 1995). Witte and Kalleberg (1995) found that fluctuations in the opportunity structure negatively influence the probability for women to hold a job that matches their field degree, but not for men. Also the search duration to find the first job increases the odds of being horizontally mismatched (Robert, 2014).

\subsubsection{Job-related determinants}

In terms of job-related factors (Table 2.6), employees' tenure appears to be negatively related to horizontal mismatch (Witte \& Kalleberg, 1995; Wolbers, 2003). A potential explanation for this finding is that once employees find a job that matches their education and the returns to schooling meet a certain level, employees will not be incentivized to change jobs (Witte \& Kalleberg, 1995). Another possible explanation is that as job tenure increases, employees accumulate firm-specific skills which are less attractive to other firms. Consequently, it is more difficult for mismatched employees with a longer tenure to search for a matching job outside the firm. Also graduates with a temporary contract are more likely to be mismatched than employees with a permanent contract (Boudarbat \& Chernoff, 2012; Wolbers, 2003). Temporary jobs offer limited opportunities to acquire relevant work experience and productive skills as opposed to permanent employment. 


\section{Table 2.5: Labour market-related determinants of horizontal mismatch (=treated as the outcome variable)}

\begin{tabular}{|c|c|c|c|c|c|}
\hline & & \multicolumn{4}{|c|}{ Labour market-related determinants } \\
\hline $\begin{array}{l}\text { Author } \\
\text { (year of } \\
\text { publication) }\end{array}$ & $\begin{array}{l}\text { Country of study } \\
\text { and definition used }\end{array}$ & & $\begin{array}{l}\text { State of the } \\
\text { economy } \\
\text { (unemployment rate) }\end{array}$ & $\begin{array}{l}\text { Opportunity structured } \\
\text { (men/women) }\end{array}$ & $\begin{array}{l}\text { Job search } \\
\text { duration }\end{array}$ \\
\hline $\begin{array}{l}\text { Witte et al. } \\
\text { (1995) }\end{array}$ & Germany & $\mathrm{C}$ & & $\begin{array}{l}\text { Ratio unemployed } \\
\text { employees to number } \\
\text { of available vacancies } \\
\text { for a specific } \\
\text { occupational group: } \\
\text { n.e./+ }\end{array}$ & \\
\hline Wolbers (2003) & $\begin{array}{l}13 \\
\text { countries }^{b}\end{array}$ & $\mathrm{D}$ & + & & \\
\hline $\begin{array}{l}\text { Hensen et al. } \\
(2009)\end{array}$ & The Netherlands & B & n.e. & & \\
\hline Malamud (2011) & $\begin{array}{l}\text { England and } \\
\text { Scotland }\end{array}$ & $\mathrm{D}$ & & & \\
\hline Robert (2014) & $\begin{array}{l}\text { Hungary, Poland, } \\
\text { Lithuania and } \\
\text { Slovenia }\end{array}$ & A & & & + \\
\hline
\end{tabular}

Notes: + indicates a positive relation between horizontal mismatch and the determinant, - indicates a negative relation, and n.e. indicates that no effect was found. a. Definition of horizontal mismatch: A. based on self-report on whether a specific field of education was required for the job B. based on respondents' assessment of the extent to which their current occupation is related to their attended field of education C. based on respondents' assessment of whether or not they have been trained for their current employment D. objective measure. b. The 13 countries comprise Austria, Belgium, Denmark, Spain, Finland, France, Greece, Hungary, Italy, Luxembourg, The Netherlands, Sweden and Slovenia.

Given that employees with a temporary contract are expected to leave the company earlier, employers are generally reluctant to offer company-funded training due to the shorter payback period of such investments (Becker, 1994; Booth, Francesconi \& Frank, 2002). Consequently, job-education mismatch can serve as a compensation for the lack of human capital that is typically gained through on-the-job training and work experience (Groot \& Maassen van den Brink, 1996). Robert (2014) found that the odds of being horizontally mismatched are higher for employees with a permanent contract than for employees with a fixed term contract or self-employed employees. Arguably, employees might also accept horizontal mismatch in return for job safety provided by a permanent contract.

Variations in the prevalence of horizontal mismatch are also found across occupational groups and sectors. Bender and Roche (2013) indicated that self-employed workers are more likely to be severely mismatched than wage or salary workers. ${ }^{7}$ Whilst self-

7 The results are robust to heterogeneity between the self-employed,wage-, and salaryworkers (choosing self-employment to obtain a better work-life balance or due to prior labour market experiences). Moreover, the results are robust to selection into self-employment because of 
employed men are more likely to be mismatched predominantly due to working conditions, self-employed women tend to accept horizontal mismatch mainly for familyrelated reasons. Employees in specialized occupations, managers, professionals, associate professionals and women in white-collar jobs are less likely to be horizontally mismatched than employees in elementary occupations (Farooq, 2011; Witte \& Kalleberg, 1995). This can be explained by the fact that the duties and requirements for white-collar occupations, also in terms of the education acquired, are less specifically defined.

With respect to the sector in which individuals are employed, the likelihood of horizontal match is greater in the public sector than in the private sector (Wolbers, 2003). This can be attributed to the fact that the public sector consists of all healthcare and educational organizations which, on average, employ more graduates who received vocationally oriented education. With respect to firm characteristics, being employed in a large firm can provide a relatively large set of opportunities to find a matching job (Hamilton, 1987). Wolbers (2003) found that employees in larger firms are more likely to be well matched. Contrariwise, Witte and Kalleberg (1995) found that the likelihood of horizontal mismatch for men increases with the size of the firm (Witte and Kalleberg, 1995). Arguably, individuals employed in large firms might be more incentivized to accept horizontal mismatch due to higher wages, job security and other job advantages offered by large firms (Kalleberg \& Van Buren, 1992).

previously being mismatched in a wage or salary job. The results also remain unchanged when managers are left out of the dataset. Employees who climb up the career ladder into management use skills that deviate from those acquired through formal education. 
Table 2.6: Job-related determinants of horizontal mismatch (=treated as the outcome variable)

\begin{tabular}{|c|c|c|c|c|c|c|c|c|c|c|}
\hline \multirow[b]{2}{*}{$\begin{array}{l}\text { Author } \\
\text { (year of } \\
\text { pub.) }\end{array}$} & \multirow{2}{*}{\multicolumn{2}{|c|}{$\begin{array}{l}\text { Country of } \\
\text { study } \\
\text { and definition } \\
\text { used }^{\mathrm{a}}\end{array}$}} & \multicolumn{8}{|c|}{ Job-related determinants } \\
\hline & & & $\begin{array}{l}\text { Job } \\
\text { tenure }\end{array}$ & $\begin{array}{l}\text { Type of contract } \\
\text { (ref. cat. = } \\
\text { permanent/full- } \\
\text { time contract) }\end{array}$ & $\begin{array}{l}\text { Occupational group } \\
\text { (men/women) }\end{array}$ & $\begin{array}{l}\text { Occupational } \\
\text { cultures of } \\
\text { training } \\
\text { (men/ } \\
\text { women) }\end{array}$ & $\begin{array}{l}\text { Sector } \\
\text { (early career/late } \\
\text { career) }\end{array}$ & $\begin{array}{l}\text { Firm size } \\
\text { (men/ } \\
\text { women) }\end{array}$ & $\begin{array}{l}\text { Method to obtain } \\
\text { employment }\end{array}$ & $\begin{array}{l}\text { Job } \\
\text { specificity }\end{array}$ \\
\hline $\begin{array}{l}\text { Witte et } \\
\text { al. } \\
(1995)\end{array}$ & Germany & $\mathrm{C}$ & - & & $\begin{array}{l}\text { Ref. cat=blue-collar } \\
\text {-White-collar: n.e./- } \\
\text {-Civil servants: } \\
\text { n.e./- }\end{array}$ & -/n.e. & & $+/$ n.e. & & \\
\hline $\begin{array}{l}\text { Wolbers } \\
\text { (2003) }\end{array}$ & $\begin{array}{l}13 \\
\text { countries }^{b}\end{array}$ & $\mathrm{D}$ & - & $\begin{array}{l}\text {-Part-time: + } \\
\text {-Fixed term ": + }\end{array}$ & & & $\begin{array}{l}\text { Ref.cat. }=\text { private } \\
\text {-Public: - }\end{array}$ & - & & \\
\hline $\begin{array}{l}\text { Bender } \\
\text { et al. } \\
(2011)\end{array}$ & $\begin{array}{l}\text { United } \\
\text { States }\end{array}$ & B & & & & & $\begin{array}{l}\text { Ref. cat }=\text { academia } \\
\text { Government: }+/ \text { n.e. } \\
\text { Business: }+/ \text { n.e. }\end{array}$ & & & \\
\hline $\begin{array}{l}\text { Farooq } \\
(2011)\end{array}$ & Pakistan & B & & & $\begin{array}{l}\text { Ref.cat=employees } \\
\text { in elementary } \\
\text { occupations: } \\
\text {-Manager: - } \\
\text {-Professional: - } \\
\text {-Associate } \\
\text { professional: - }\end{array}$ & & & & & \\
\hline $\begin{array}{l}\text { Klein } \\
\text { (2011) }\end{array}$ & Germany & $\mathrm{D}$ & & $\begin{array}{l}\text {-Part-time: n.e. } \\
\text {-Fixed term: n.e. }\end{array}$ & & & $\begin{array}{l}\text { Ref.cat.=private } \\
\text { manufacturing } \\
\text {-Civil service: - } \\
\text {-Private service: n.e. } \\
\text { - }\end{array}$ & n.e. & & - \\
\hline
\end{tabular}


Table 2.6 (continued)

\begin{tabular}{|c|c|c|c|c|c|c|c|c|c|}
\hline & & & \multicolumn{7}{|c|}{ Job-related determinants } \\
\hline $\begin{array}{l}\text { Author } \\
\text { (year of } \\
\text { pub.) }\end{array}$ & $\begin{array}{l}\text { Country of } \\
\text { study } \\
\text { and } \\
\text { definition }^{\text {used }} \\
\end{array}$ & & $\begin{array}{l}\text { Job } \\
\text { tenure }\end{array}$ & $\begin{array}{l}\text { Type of contract } \\
\text { (ref. cat. = } \\
\text { permanent/full- } \\
\text { time contract) }\end{array}$ & $\begin{array}{l}\text { Occupational } \\
\text { group } \\
\text { (men/women) }\end{array}$ & $\begin{array}{l}\text { Occupational } \\
\text { cultures of } \\
\text { training (men/ } \\
\text { women) }\end{array}$ & $\begin{array}{l}\text { Sector } \\
\text { (early career/late } \\
\text { career) }\end{array}$ & $\begin{array}{l}\text { Firm size (men/ } \\
\text { women) }\end{array}$ & $\begin{array}{l}\text { Method to obtain } \\
\text { employment }\end{array}$ \\
\hline $\begin{array}{l}\text { Boudar- } \\
\text { bat et al. } \\
(2012)\end{array}$ & Canada & $\mathrm{B}$ & & $\begin{array}{l}\text {-Part-time: }+ \\
\text {-Fixed term: n.e. }\end{array}$ & & & & & $\begin{array}{l}\text { Ref.cat.= referred by } \\
\text { someone: } \\
\text {-Answered job ad: n.e. } \\
\text {-Directly contacted } \\
\text { employer: n.e. } \\
\text {-Campus placement } \\
\text { agency:- } \\
\text {-Employment agency: } \\
\text { n.e. } \\
\text {-Head hunter: n.e. }\end{array}$ \\
\hline $\begin{array}{l}\text { Kucel et } \\
\text { al. (2012) }\end{array}$ & Poland & A & n.e. & & & & & n.e. & \\
\hline $\begin{array}{l}\text { Bender } \\
\text { et al. } \\
(2013)\end{array}$ & $\begin{array}{l}\text { United } \\
\text { States }\end{array}$ & $\mathrm{B}$ & & & $\begin{array}{l}\text { Ref. cat=wage and } \\
\text { salary employees: } \\
\text {-Severely } \\
\text { mismatched self- } \\
\text { employed: + }\end{array}$ & & & & \\
\hline $\begin{array}{l}\text { Robert } \\
\text { (2014) }\end{array}$ & $\begin{array}{l}\text { Hungary, } \\
\text { Poland, } \\
\text { Lithuania } \\
\text { and } \\
\text { Slovenia }\end{array}$ & A & & $\begin{array}{l}\text { Temporary/ } \\
\text { part-time: - }\end{array}$ & & & & & \\
\hline
\end{tabular}

\footnotetext{
Notes: + indicates a positive relation between horizontal mismatch and the determinant, - indicates a negative relation, and n.e. indicates that no effect was found. a. Definition of horizontal mismatch: A. based on self-report on whether a specific field of education was required for the job B. based on respondents' assessment of the extent to which their current occupation is related to their attended field of education C. based on respondents' assessment of whether or not they have been trained for their current employment D. objective measure. b. The 13 countries comprise Austria, Belgium, Denmark, Spain, Finland, France, Greece, Hungary, Italy, Luxembourg, The Netherlands, Sweden and Slovenia.
} 


\subsubsection{Determinants related to individual characteristics}

Finally, several individual characteristics relate to employees' labour market outcomes (Table 2.7). For instance, labour market prospects and outcomes are found to differ between men and women along various dimensions (Altonji \& Blank, 1999). This also holds for obtaining a job that matches one's field degree. Bender and Heywood (2011) demonstrate that males are more likely to be mismatched than females. However, as the findings apply to $\mathrm{PhD}$ graduates in a science, mathematics or engineering field, these results cannot be generalized. Other studies provide evidence that females are more likely to be mismatched as opposed to their male counterparts (Farooq, 2011; Hensen et al., 2009). For men, mismatch is more likely to be the result of career-oriented reasons like pay and promotion opportunities, or changing career interests, whilst women are more likely to report mismatch due to family-related reasons, the job location or working conditions (Bender \& Heywood, 2011; Robst, 2007b). Bender and Roche (2013) found that in the wage and salary sector, women are less likely to be severely mismatched than their male counterparts. In contrast, self-employed women are more likely to be severely mismatched than self-employed men. Self-employment might provide an involuntary alternative for female workers who seek more flexible working arrangements.

The probability of being horizontally mismatched also relates to employees' age (Bender \& Roche, 2013; Wolbers, 2003). Using a panel framework, Bender and Heywood (2011) demonstrated that employees are most likely to make the transition from a state of mismatch to a state of match in early stages of their career. This is consistent with the idea that mismatch is a result of employees' career evolution and not necessarily an indicator of labour market inefficiency. Besides the fact that career interests might change over time, the value of the stock of human capital accumulated through formal education depreciates over time and reinvesting in rapidly depreciating skills becomes less attractive as the length of the payback period shortens. Moreover, the skills acquired through vocational education become less relevant over time in the presence of technological changes (Witte \& Kalleberg, 1995). Hensen et al. (2009), on the other hand, found that employees' age is positively associated with holding a job that matches the field of education. Robert (2014) also found a negative relation between horizontal mismatch and age; however, this effect vanishes when the sample is reduced to respondents who left their first job. As the latter two studies use samples consisting of recent graduates, it appears that it takes some employees more time to find an appropriate job upon labour market entry. After some point, however, the probability of becoming horizontally mismatched arguably increases. 
Table 2.7: Individual-related determinants of horizontal mismatch (=treated as the outcome variable)

\begin{tabular}{|c|c|c|c|c|c|c|c|c|c|c|}
\hline \multirow[b]{2}{*}{$\begin{array}{l}\text { Author (year of } \\
\text { pub.) }\end{array}$} & \multirow{2}{*}{\multicolumn{2}{|c|}{$\begin{array}{l}\text { Country of study } \\
\text { and definition } \\
\text { used }^{\mathrm{a}}\end{array}$}} & \multicolumn{8}{|c|}{ Individual-related determinants } \\
\hline & & & $\begin{array}{l}\text { Gender } \\
\text { (ref. cat.= } \\
\text { women) }\end{array}$ & Age & $\begin{array}{l}\text { Abi- } \\
\text { lity }\end{array}$ & Parental education & $\begin{array}{l}\text { Ethnicity } \\
\text { (men/women) }\end{array}$ & Job mobility & $\begin{array}{l}\text { Marital status } \\
\text { (ref. cat. }= \\
\text { married) }\end{array}$ & $\begin{array}{l}\text { Dis- } \\
\text { ability }\end{array}$ \\
\hline Witte et al. (1995) & Germany & $\mathrm{C}$ & + & + & & & & & & \\
\hline Wolbers (2003) & 13 countries $^{b}$ & $\mathrm{D}$ & + & + & & & & & & \\
\hline Robst (2007a) & United States & $\mathrm{B}$ & + & + & & & $\begin{array}{l}\text { Ref. cat.=white: } \\
\text {-Asians: + /n.e. } \\
\text {-Black: - } \\
\text {-Native } \\
\text { Americans:n.e. } \\
\text {-Hispanics: - }\end{array}$ & & + & + \\
\hline Robst (2007b) & United States & $\mathrm{B}$ & + & & & & & & & \\
\hline $\begin{array}{l}\text { Hensen et al. } \\
(2009)\end{array}$ & $\begin{array}{l}\text { The } \\
\text { Netherlands }\end{array}$ & $\mathrm{B}$ & - & - & & & $\begin{array}{l}\text { Ref. cat. }=\text { natives: } \\
\text {-Immigrants: }+\end{array}$ & Geographic:+ & & \\
\hline $\begin{array}{l}\text { Bender et al. } \\
\text { (2011) }\end{array}$ & United States & $\mathrm{B}$ & + & + & & & & & & n.e. \\
\hline Farooq (2011) & Pakistan & $\mathrm{B}$ & - & & & & & & & \\
\hline $\begin{array}{l}\text { Boudarbat et al. } \\
(2012)\end{array}$ & Canada & $\mathrm{B}$ & n.e. & n.e. & - & $\begin{array}{l}\text { Ref. cat. }=\text { parents with } \\
\text { less than secondary } \\
\text { education: } \\
\text {-Secondary: n.e. } \\
\text {-Some postsecondary: } \\
\text { n.e. } \\
\text {-Trade: }+ \\
\text {-Postsecondary: n.e. } \\
\text {-Bachelor: n.e. } \\
\text {-Postgrad: n.e. }\end{array}$ & $\begin{array}{l}\text { Ref. cat. = natives: } \\
\text {-Immigrants: }+\end{array}$ & & & \\
\hline Kucel et al. (2012) & Poland & A & n.e. & n.e. & - & & & & & \\
\hline $\begin{array}{l}\text { Bender et al. } \\
(2013)\end{array}$ & United States & $\mathrm{B}$ & $\begin{array}{l}\text {-Wage } \\
\text { employees: + } \\
\text {-Self- } \\
\text { employed: - }\end{array}$ & + & & & $\begin{array}{l}\text { Ref. cat=white: } \\
\text {-Asians: n.e. } \\
\text {-Black: n.e. } \\
\text {-Hispanics: - }\end{array}$ & & + & \\
\hline
\end{tabular}


Table 2.7 (continued)

\begin{tabular}{|c|c|c|c|c|c|c|c|c|c|c|}
\hline & & & \multicolumn{8}{|c|}{ Individual-related determinants } \\
\hline $\begin{array}{l}\text { Author (year of } \\
\text { pub.) }\end{array}$ & $\begin{array}{l}\text { Country of } \\
\text { study } \\
\text { and } \\
\text { definition }^{\text {used }}\end{array}$ & & $\begin{array}{l}\text { Gender } \\
\text { (ref. cat. }= \\
\text { women) }\end{array}$ & Age & $\begin{array}{l}\text { Abi- } \\
\text { lity }\end{array}$ & Parental education & $\begin{array}{l}\text { Ethnicity } \\
\text { (men/women) }\end{array}$ & Job mobility & $\begin{array}{l}\text { Marital status } \\
\text { (ref. cat.= } \\
\text { married) }\end{array}$ & $\begin{array}{l}\text { Dis- } \\
\text { ability }\end{array}$ \\
\hline Robert (2014) & $\begin{array}{l}\text { Hungary, } \\
\text { Poland, } \\
\text { Lithuania and } \\
\text { Slovenia }\end{array}$ & A & n.e. & n.e. & & $\begin{array}{l}\text { Ref. cat.=parents with } \\
\text {-ISCED 5-6: } \\
\text {-ISCED 3-4: + } \\
\text {-ISCED 1-2: n.e. }\end{array}$ & & $\begin{array}{l}\text {-Number of } \\
\text { jobs: }+ \\
\text {-Left first } \\
\text { job: } \text { n.e. }\end{array}$ & & \\
\hline $\begin{array}{l}\text { Verhaest et al. } \\
\text { (2017) }\end{array}$ & 18 countries $^{d}$ & $\mathrm{~B}$ & $\begin{array}{l}\text {-If HM: n.e. } \\
\text {-If } \\
\text { HM+VM:- }\end{array}$ & $\begin{array}{l}\text {-If HM: } \\
\text { n.e. } \\
\text {-If } \\
\text { HM+V } \\
\text { M:+ }\end{array}$ & - & & & & & \\
\hline
\end{tabular}

Notes: + indicates a positive relation between horizontal mismatch and the determinant, - indicates a negative relation, and n.e. indicates that no effect was found. a. Definition of horizontal mismatch: A. based on self-report on whether a specific field of education was required for the job B. based on respondents' assessment of the extent to which their current occupation is related to their attended field of education C. based on respondents' assessment of whether or not they have been trained for their current employment D. objective measure. b. The 13 countries comprise Austria, Belgium, Denmark, Spain, Finland, France, Greece, Hungary, Italy, Luxembourg, The Netherlands, Sweden and Slovenia. d. The 18 countries comprise Austria, Belgium (Flanders), Czech Republic, Estonia, Finland, France, Germany, Hungary, Italy, Japan, the Netherlands, Norway, Poland, Portugal, Slovakia, Spain, Switzerland and the U.K. 
In addition to gender and age, a substantial amount of studies point at the presence of racial differentials in labour market outcomes (e.g. Altonji \& Blank, 1999; Boudarbat \& Chernoff, 2012; Hensen et al. 2009). Empirical evidence suggests that compared to white employees, the likelihood of being horizontally mismatched is higher for Asian men and lower for black employees and Hispanics (Bender \& Roche, 2013; Robst, 2007a). Black employees are more likely to be mismatched because a related job was unavailable, whilst they are less likely to report mismatch as a result of the job conditions, changing career interests or family-related reasons. ${ }^{8}$

An individual factor that strongly predicts educational as well as labour market outcomes is the individual's ability. Graduates in lower grade categories are significantly less likely to find a job that relates to the field-of-study compared to graduates in the highest grade category (Boudarbat \& Chernoff, 2012; Kucel \& Vilalta-Bufí, 2012). Employers could use high grades as a signal for the quality of an individual's subject-related skills.

In addition to individual-related determinants that are exogenously determined, individuals make choices that affect their labour market outcomes (Büchel \& Van Ham, 2003). One might hypothesize that the extent to which employees are willing to seek for a job outside the place of residence reduces the probability of an education-job mismatch. However, geographic mobility or intensive job shifts has a negative effect on the likelihood of being horizontally matched (Hensen et al., 2009; Robert, 2014). This might suggest that intensive job search merely reflects an instable labour market position. Finally, disabled employees face a higher chance of obtaining a job that does not match their field-of-study (Bender \& Heywood, 2011; Robst, 2007a). The difference between the disabled and the non-disabled is particularly evident when a job is accepted outside the field degree for the reason that a related job was not available (Robst, 2007a). For employees in their late career stage, Bender and Heywood (2011) found no effect. Regarding individuals' marital status, individuals who are not or have never been married are more likely to be mismatched than employees who are married (Bender \& Roche, 2013; Robst, 2007a). ${ }^{9}$

While the studies under review offer an extensive list of factors determining the likelihood that individuals experience horizontal mismatch, the relation between the

\footnotetext{
8 Robst (2007b) used the same dataset as Robst (2007a). Robst (2007a) found, compared to white employees, a significant positive effect for Asian men, but no effect for women. Furthermore, where Robst (2007a) found a significant negative effect for black employees, Robst (2007b) found no significant differences between white and black employees.

${ }^{9}$ In contrast to Robst (2007a), Robst (2007b) found that employees who have never been married are less likely to be mismatched.
} 
identified determinants and horizontal mismatch might also interact in many ways that are not assessed by the papers included in this review. For instance, Robst (2007b) indicates that women are more likely to experience mismatch due to family-related reasons. Given that family-related reasons are more likely to play a role at a certain age, age interacts with the relation between horizontal mismatch and gender. Given that the articles included in this review dealt with different countries, findings on how variables such as gender and race relate to horizontal mismatch might also be influenced by country norms. Finally, the incidence of horizontal mismatch changes over time as the demand and supply of skills in the labour markets is not time constant (Goldin \& Katz, 1996).

\subsection{Outcomes associated with horizontal mismatch}

Table 2.8 provides an overview of the outcomes associated with horizontal mismatch. As Table 2.8 depicts, a substantial amount of economic research has been conducted on the relation between horizontal mismatch and employees' earnings. Social stratification research, on the other hand, has been concerned with the association between horizontal mismatch and employees' occupational status. Furthermore, the studies selected for our review have examined what horizontal mismatch implies for on-the-job search, training participation, job satisfaction and regret of the chosen field-of-study.

Most studies assessing the wage implications of horizontal mismatch compare wellmatched employees to their mismatched counterparts who hold the same field degree. Employees who are horizontally mismatched generally incur a wage penalty. Some employees, despite being mismatched, are still able to utilize some of the skills acquired through their field degree and, therefore, only incur small wage penalties (Bender \& Heywood, 2011; Bender \& Roche, 2013; Nordin, Persson \& Rooth, 2010; Robst, 2007b; Yakusheva, 2010). Robst (2007b) showed that whereas mismatched men receive a wage penalty of 11.9 percent, partially mismatched men only incur a wage loss of 2.9 percent. The wage penalties incurred by mismatched and partially mismatched women are 10.1 and 2.1 percent, respectively.

The wage effect differs across reasons for accepting horizontal mismatch (Robst, 2007a). The wage loss accompanied with horizontal mismatch because of the job location or family-related reasons, ranges from 18.1 to 29.3 percent for men and from 17.2 to 21.5 percent for women (Robst, 2007a). The pay penalties associated with the inability to find a matching job is 18.5 percent for females and 26.5 percent for men. In contrast, accepting horizontal mismatch because of pay and promotion opportunities is associated with a wage gain of 9.1 percent mismatch does not always have negative wage 
consequences. Similarly, Zhu (2014) showed that 32.3 percent of the Chinese college graduates benefit from being horizontally mismatched as they receive a wage premium.

The wage effects also vary among employees in different types of employment. Compared to matched wage and salary workers, the severely mismatched self-employed incur wage penalties twice as large as mismatched wage and salary workers (Bender \& Roche, 2013). ${ }^{10}$ In line with Robst (2007a), the greatest wage penalties are incurred when a matching job is unavailable. Mismatch also carries different wage penalties depending on employees' career stage. Bender and Heywood (2011) found greater wage penalties for mismatched employees later in their career stage than for those in the early stage of their career. As older mismatched employees are being compared with well-matched employees in the reward phase of their earnings profile, employees in later stages of their career face larger wage penalties in comparison to employees early in their career.

Zhu (2014) found relatively small wage penalties, namely, 1.2 percent for men and 1.5 percent for women. Zhu (2014) attributed these small wage losses to the strong emphasis of the Chinese education system on providing students general skills. ${ }^{11}$ Such skills are believed to be transferable and rewarded in all occupations. Similarly, Nordin et al. (2010) argued that although employees who attended a field that mainly provides job-specific skills are less likely to be horizontally mismatched, they generally incur a larger wage penalty than employees who predominantly acquired general skills through their field-ofstudy. In fact, graduates with a degree in medicine, which is known to provide highly jobspecific skills, suffer from the largest wage losses when experiencing horizontal mismatch (Zhu, 2014). Having a major in literature, on the other hand, provides rather general skills and is associated with the smallest wage penalties in the case of mismatch (Zhu, 2014).

In order to offset initial skill deficiencies, employees who are horizontally mismatched upon labour market entry might acquire additional skills on the job. Nordin et al. (2010) showed that the return to work experience for mismatched men is significantly greater than for well-matched men. This supports the idea that mismatched employees reduce their initially incurred wage penalty by gaining relevant skills on the job. Likewise, Malamud (2010) showed that being mismatched in the first year after graduation yields a wage loss of 7 percentage points. However, compared to graduates who are matched upon labour market entry, initially mismatched employees do not significantly earn lower wages six years after graduation. This suggests that horizontal mismatch is only a temporary phenomenon.

10 These results were obtained whilst including heterogeneity controls, that is, having children between the age of 6 and 11 and previous labour market experiences.

11 Zhu (2014) employs a nonparametric model. The wage penalty associated with horizontal mismatch was found to be much larger with the OLS approach, namely, 5.9 percent. 
According to the job search theory, mismatched employees might also try to improve their fit by changing jobs until an optimal match is reached (Jovanovic, 1979). The probability to look for another job appears to be larger for employees who are horizontally mismatched than for well-matched employees (Béduwé \& Giret, 2011; Malamud, 2010; Wolbers, 2003). Moreover, mismatched employees are more actively engaged in job search activities in countries with a low vocational orientation (Wolbers, 2003). This supports the view that vocational education functions as a safety net (Shavit \& Muller, 2000), reducing the risk of unemployment or ending up in unskilled employment. Some studies found no relation between horizontal mismatch and on-thejob search (Allen \& Van der Velden, 2001; Shevchuk, Strebkov \& Davis, 2015).

A different strategy to cope with skill mismatch is to participate in additional on-the-job training to offset the shortcoming of the skills acquired through initial education (Wolbers, 2003). The idea is that horizontally matched employees more optimally utilize their skills which reduces the need to invest in additional training. Unexpectedly, Wolbers (2003) found that mismatched school-leavers participate significantly less in additional training than their well-matched counterparts. However, the effect of job mismatches on training participation turns out to be positive in countries characterized by low shares of school-based vocational education and apprenticeship trainings. Arguably, graduates who have acquired general education more often receive training on the job to acquire jobspecific skills which were not offered through formal education.

Where most economic studies focus on the wage consequences of mismatch, most research on social stratification assesses what mismatch entails for employees' occupational status. On average, mismatched employees have an occupational status that is lower than for well-matched employees (Wolbers, 2003). The loss in occupational status associated with mismatch is lower in countries characterized by an education system that is more vocationally oriented.

Various studies found a positive relationship between horizontal mismatch and employees' level of job satisfaction. The size of the relation between horizontal mismatch and job satisfaction decreases when controlling for certain job attributes such as having a permanent position or being employed in an organization with large internal labour markets. To put it differently, individuals appear to be willing to accept a job that does not match their field-of-study in exchange for a job that offers satisfactory perspectives such as job stability and professional development. 
Table 2.8: Parameter estimates of the outcomes associated with horizontal mismatch (= treated as the predictor variable here)

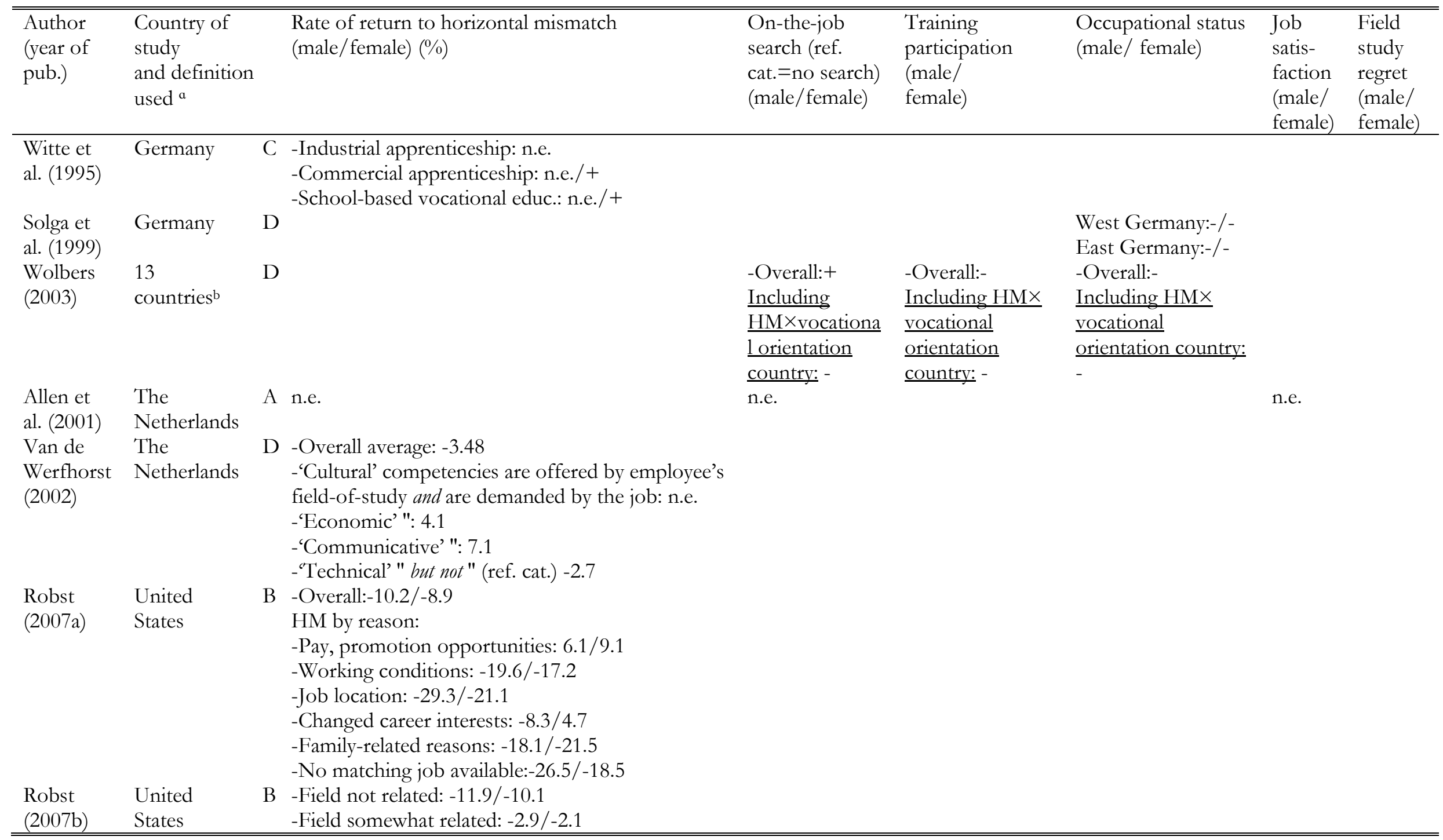


Table 2.8 (continued)

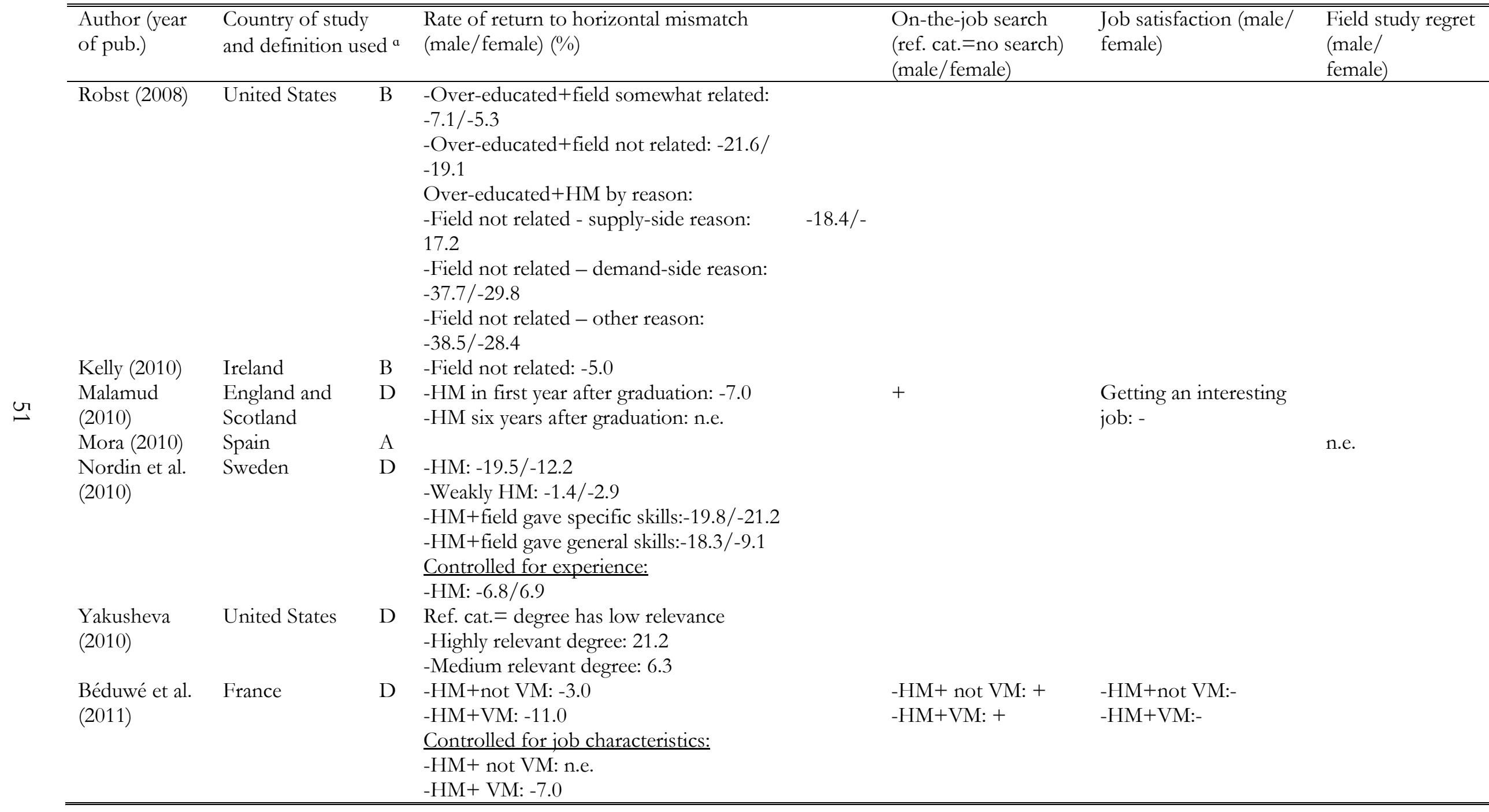


Table 2.8 (continued)

\begin{tabular}{|c|c|c|c|c|c|c|}
\hline $\begin{array}{l}\text { Author (year } \\
\text { of pub.) }\end{array}$ & $\begin{array}{l}\text { Country of } \\
\text { study } \\
\text { and definition } \\
\text { used a }\end{array}$ & & $\begin{array}{l}\text { Rate of return to horizontal mismatch } \\
\text { (male/female) }(\%)\end{array}$ & $\begin{array}{l}\text { On-the-job search } \\
\text { (ref. cat.=no search) } \\
\text { (male/female) }\end{array}$ & $\begin{array}{l}\text { Job satisfaction (male/ } \\
\text { female) }\end{array}$ & $\begin{array}{l}\text { Field study } \\
\text { regret (male/ } \\
\text { female) }\end{array}$ \\
\hline $\begin{array}{l}\text { Bender et al. } \\
\text { (2011) }\end{array}$ & United States & $\mathrm{B}$ & $\begin{array}{l}\text { Early career }(<10 \text { years since degree }): \\
\text {-Partly/very HM: }-1.9 / \text { n.e. } \\
\text {-Very HM: }-6.9 /-7.7 \\
\text { Late career }(>25 \text { years since degree): } \\
\text {-Partly/very HM: }-4.5 /-11.5 \\
\text {-Very HM: }-21.1 / \text { n.e. }\end{array}$ & & & \\
\hline $\begin{array}{l}\text { Kucel et al. } \\
\text { (2013) }\end{array}$ & $\begin{array}{l}\text { Spain and The } \\
\text { Netherlands }\end{array}$ & A & & & & $\begin{array}{l}\text {-Netherlands: + } \\
\text {-Spain:+ }\end{array}$ \\
\hline $\begin{array}{l}\text { Bender et al. } \\
(2013)\end{array}$ & United States & $\mathrm{B}$ & $\begin{array}{l}\text { Ref. cat. =wage/salary matched employees } \\
\text { Wage/salary employees: } \\
\text {-Moderately HM: n.e. } \\
\text {-Severely HM: }-21.1 /-15.9 \\
\text { Self-employed: } \\
\text {-Moderately HM: }-8.8 /-17.1 \\
\text {-Severely HM: }-42.8 /-33.0\end{array}$ & & $\begin{array}{l}\text { Wage/salary employees: } \\
\text {-Moderately HM:-/- } \\
\text {-Severely HM:-/- } \\
\text { Self-employed: } \\
\text {-Moderately HM:-/- } \\
\text {-Severely HM:-/- }\end{array}$ & \\
\hline Zhu (2014) & China & $\mathrm{B}$ & $-1.17 /-1.45$ & & & \\
\hline $\begin{array}{l}\text { Shevchuk et } \\
\text { al. (2015) }\end{array}$ & Russia & $\mathrm{B}$ & $\begin{array}{l}\text {-Overall: -/- } \\
\text { Controlled for caregiving (CA): } \\
-\mathrm{HM}+\mathrm{CA}: \text { n.e./- } \\
\text {-HM+not CA: -/- }\end{array}$ & $\begin{array}{l}\text {-Overall: n.e. } \\
\text { Controlled for } \\
\text { caregiving }(\mathrm{CA}): \\
\text {-HM+CA: n.e./+ } \\
\text {-HM+not CA: n.e. }\end{array}$ & $\begin{array}{l}\text {-Overall: n.e./- } \\
\text { Controlled for caregiving } \\
\text { (CA): } \\
-\mathrm{HM}+\mathrm{CA}:-/- \\
\text {-HM+not CA: n.e./- }\end{array}$ & \\
\hline
\end{tabular}

Notes: HM indicates horizontal mismatch, VM indicates vertical mismatch, + indicates a positive relation between HM and the outcome variable, - indicates a negative relation and n.e. indicates no effect. a. Definition of horizontal mismatch: A. based on self-report on whether a specific field of education was required for the job B. based on respondents' assessment of the extent to which their current occupation is related to their attended field of education C. respondents' assessment of whether or not they have been trained for their current employment D. objective measure. b. The 13 countries comprise Austria, Belgium, Denmark, Spain, Finland, France, Greece, Hungary, Italy, Luxembourg, The Netherlands, Sweden and Slovenia. 
Bender and Roche (2013) found that the association between mismatch and job satisfaction is weaker for self-employed employees than for wage and salary workers. This could indicate that despite the relative large wage penalties incurred by the mismatched self-employed, accepting horizontal mismatch in the self-employment sector offers job attributes that compensate for those wage penalties such as greater flexibility in working hours (Benz \& Frey, 2008; Connelly, 1992).

Shevchuk et al. (2015) only found a negative association between horizontal mismatch and job satisfaction among women. Allen and Van der Velden (2001) did not find any effect of horizontal mismatch on job satisfaction. However, skill underutilization does appear to negatively affect job satisfaction (Allen \& Van der Velden, 2001). Also Béduwé and Giret (2011) found that the horizontal mismatch coefficient reduces in size when including an indicator for skill utilization at the workplace. Hence, it appears to be skill underutilization that leads employees to experience job dissatisfaction. As such, comparing graduates' attended field-of-study with the educational requirements for the job is not always a perfect proxy for the degree to which employees underutilize fieldrelated skills.

\subsection{Conclusion and discussion}

Relying on a systematic literature review, the aim of this chapter is to address how prevalent horizontal mismatch is and to what extent it contributes to an inefficiently functioning labour market. In addition, we discussed the approaches in which the concept of horizontal mismatch has been operationalized in prior research and identified the factors that determine horizontal mismatch.

Several specifications of horizontal mismatch can be found in the literature, each yielding different incidence rates. The highest incidence rates are proposed by studies using an objective definition (e.g. Béduwé \& Giret, 2011; Malamud, 2011). On average, the different specifications generate incidence rates varying from 21 percent to 46 percent. The degree to which horizontal mismatch can be considered an undesirable phenomenon differs across mismatched individuals and depends among other things on the reason for accepting horizontal mismatch as well as on the degree to which skills are being underutilized. The reason for accepting a job that does not require employees' attended field-of-study may be demand as well as supply related (Robst, 2007b). The source of horizontal mismatch is considered to be demand related when a matching job is unavailable. Under this condition, horizontal mismatch can be considered a negative phenomenon given that students choose a field-of-study with the expectation of finding employment in field-related occupations (Betts, 1996; Holland, 1985). In fact, our review points out that horizontal mismatch often has unfavourable effects on employees' 
earnings, occupational status and job satisfaction (e.g. Bender \& Roche, 2013; Van de Werfhorst, 2002; Wolbers, 2003). Horizontal mismatch also increases the likelihood of experiencing programme regret which is associated with substantial costs (Borghans \& Golsteyn, 2005; Kucel \& Vilalta-Bufí, 2013). From this perspective, horizontal mismatch may reveal that the process of skill formation and the allocation of skills in the labour market are sub-optimal.

The negative consequences induced by horizontal mismatch are more ambiguous when the source of mismatch is supply related. Supply-related reasons for accepting horizontal mismatch may concern pay and promotion opportunities, or a change in career interests (Bender and Heywood, 2011; Robst, 2007a; Robst, 2007b). The majority of these employees receive a wage premium over their well-matched counterparts, suggesting that horizontal mismatch does not necessarily indicate a severe underutilization of fieldspecific skills (Robst, 2007a; Zhu, 2014). Other employees might accept horizontal mismatch in exchange for favourable job attributes such as a permanent contract or a greater flexibility in working hours (Béduwé \& Giret, 2011; Benz \& Frey, 2008; Connelly, 1992). As such, from an individual's perspective, accepting horizontal mismatch might be an economically rational decision under certain conditions. This also applies to employees in later stages of their career, especially in the presence of technological progress which induces skill obsolescence and the rise of new skill requirements (Bender \& Heywood, 2011; Witte \& Kalleberg, 1995). In fields that are sensitive to rapid changes, a greater value is being put on the skills acquired through work experience and on-the-job training. Whilst, from an individual's view, accepting mismatch can be economically rational, horizontal mismatch might still reflect an economic loss to society. This is the case when individuals' productivity level would be superior if a matching job or a different field-ofstudy would have been chosen. Whether horizontal mismatch in later career stages implies a labour market failure depends on whether employees gain new skills on the job and whether educational institutions adjust their curricula to meet changes in labour market demands.

This review proposes that future research could benefit from a more uniform measure of horizontal mismatch that directly captures the discrepancy between the job requirements and the skills acquired through the field-of-study. Besides the fact that each definition of horizontal mismatch yields varying incidence rates, the validity of the different measures that are identified in the literature can be called into question. Although individuals might be employed in similar jobs and acquired the same field degree, there might still be a discrepancy in the degree to which employees perceive the match between their job and their field-of-study. Moreover, defining employees as being poorly matched because their field degree was not a requirement for their job might also raise concerns regarding the 
validity of this definition. Where some jobs only accept individuals who have acquired a specific degree, other jobs require a set of skills that is being offered by a wider range of fields.

The current state of academic research also suffers from the absence of information and data about skills. Most studies included in this review consider educational requirements as a proxy for the knowledge and skills that are necessary to adequately perform the job. However, the knowledge and skills that are used in jobs only partially overlap with what is being taught throughout formal education. Therefore, using education as a proxy for skills might ignore other important attributes of job requirements such as on-the-job training and job experience. Nonetheless, in a context in which public education is expected to provide students with the skills that are demanded in the labour market, formal degrees can be considered a good proxy for the skills that jobs require from recent graduates with little work experience. Hence, measuring the education-job fit in terms of the attended field is more informative about the transition from recent graduates to the labour market than the extent to which older employees possess the skills that are required for the job. Future research on skill mismatches could therefore benefit from the availability of data on the knowledge and skills required for jobs. 


\section{Appendix 2.1: Overview of the selected studies}

\section{Table 2.9: Overview of the selected studies}

\begin{tabular}{|c|c|c|c|c|c|c|c|}
\hline & $\begin{array}{l}\text { Author } \\
\text { (year of } \\
\text { pub.) }\end{array}$ & Country of study & $\begin{array}{l}\text { Data source, type of } \\
\text { data and year of data } \\
\text { collection }\end{array}$ & Sample population & Statistical method & $\begin{array}{l}\text { Determinants of horizontal } \\
\text { mismatch }\end{array}$ & $\begin{array}{l}\text { Effects of } \\
\text { horizontal } \\
\text { mismatch }\end{array}$ \\
\hline 1 & $\begin{array}{l}\text { Witte \& } \\
\text { Kalleberg } \\
(1995)\end{array}$ & Germany & $\begin{array}{l}\text { German } \\
\text { Socioeconomic Panel } \\
\text { (GSOEP) - cross- } \\
\text { sectional - 1984-1990a }\end{array}$ & $\begin{array}{l}\text { Representative } \\
\text { household panel (final } \\
\text { sample for models of } \\
\text { mismatch determinants: } \\
\text { men: } \mathrm{n}=1,008 \text {; } \\
\text { women: } \mathrm{n}=637 \text {. Final } \\
\text { sample for models of } \\
\text { mismatch effects: men: } \\
\mathrm{n}=1,881 \text {; women: } \mathrm{n}= \\
1,207 \text { ). }\end{array}$ & $\begin{array}{l}\text {-Logistic regression } \\
\text { to examine } \\
\text { determinants } \\
\text {-OLS regression to } \\
\text { examine effects }\end{array}$ & $\begin{array}{l}\text {-Type of vocational education } \\
\text {-Opportunity structure } \\
\text {-Job tenure } \\
\text {-Occupational group } \\
\text {-Firm size } \\
\text {-Occupation 'cultures of } \\
\text { training' } \\
\text {-Gender } \\
\text {-Age }\end{array}$ & Wage \\
\hline 2 & $\begin{array}{l}\text { Allen \& } \\
\text { van der } \\
\text { Velden } \\
(2001)\end{array}$ & The Netherlands & $\begin{array}{l}\text { Data were collected } \\
\text { for the project } \\
\text { 'Higher Education } \\
\text { and Graduate } \\
\text { Employment in } \\
\text { Europe' - cross- } \\
\text { sectional - } 1998\end{array}$ & $\begin{array}{l}\text { Tertiary education } \\
\text { graduates who } \\
\text { graduated in } 1990 / 1991 \\
\text { and held a job of at } \\
\text { least } 12 \text { hours per week } \\
\text { at the time of the survey } \\
\text { (final sample: } n= \\
2,460 \text { ). }\end{array}$ & $\begin{array}{l}\text {-OLS: wage effects } \\
\text {-Logistic regression: } \\
\text { effect on on-the-job } \\
\text { search and job } \\
\text { satisfaction }\end{array}$ & & $\begin{array}{l}\text {-Wage } \\
\text {-On-the-job } \\
\text { search } \\
\text {-Job } \\
\text { satisfaction }\end{array}$ \\
\hline 3 & $\begin{array}{l}\text { Van de } \\
\text { Werfhorst } \\
(2002)\end{array}$ & The Netherlands & $\begin{array}{l}\text { Survey from The } \\
\text { Netherlands Institute } \\
\text { for Social Research } \\
\text { (SCP) - time series - } \\
\text { 1991,1995 }\end{array}$ & $\begin{array}{l}\text { Employed individuals } \\
\text { aged } 21-64 \text { years with a } \\
\text { minimum of } 15 \\
\text { working hours per week } \\
\text { (final sample: } \mathrm{n}= \\
6,373 \text { ). }\end{array}$ & $\begin{array}{l}\text { OLS regression: } \\
\text { wage effects }\end{array}$ & & Wage \\
\hline
\end{tabular}


Appendix 2.1 (continued)

\begin{tabular}{|c|c|c|c|c|c|c|c|}
\hline & $\begin{array}{l}\text { Author } \\
\text { (year of } \\
\text { pub.) }\end{array}$ & Country of study & $\begin{array}{l}\text { Data source, type of } \\
\text { data and year of data } \\
\text { collection }\end{array}$ & Sample population & Statistical method & $\begin{array}{l}\text { Determinants of horizontal } \\
\text { mismatch }\end{array}$ & $\begin{array}{l}\text { Effects of } \\
\text { horizontal } \\
\text { mismatch }\end{array}$ \\
\hline 4 & $\begin{array}{l}\text { Wolbers } \\
(2003)\end{array}$ & $\begin{array}{l}\text { Austria, } \\
\text { Belgium, } \\
\text { Denmark, Spain, } \\
\text { Finland, France, } \\
\text { Greece, } \\
\text { Hungary, Italy, } \\
\text { Luxembourg, } \\
\text { The } \\
\text { Netherlands, } \\
\text { Sweden and } \\
\text { Slovenia. }\end{array}$ & $\begin{array}{l}2000 \text { ad hoc module } \\
\text { of the European } \\
\text { Labour Force Survey } \\
\text { (EU LFS 2000) - } \\
\text { cross-sectional - } 2000\end{array}$ & $\begin{array}{l}\text { Individuals aged } 15-35 \\
\text { years who left formal } \\
\text { education within the } \\
\text { past five years (Finland, } \\
\text { Luxembourg, the } \\
\text { Netherlands and } \\
\text { Sweden) or ten years } \\
\text { (all other countries) } \\
\text { years } \\
\text { (final sample: } \mathrm{n}= \\
\text { 36,268). }\end{array}$ & $\begin{array}{l}\text {-Logistic regression } \\
\text { to examine } \\
\text { determinants } \\
\text {-Logistic regression: } \\
\text { effects }\end{array}$ & $\begin{array}{l}\text {-Field-of-study } \\
\text {-Level of education } \\
\text {-Type of vocational education } \\
\text {-State of the economy } \\
\text {-Job tenure } \\
\text {-Type of contract } \\
\text {-Firm size } \\
\text {-Sector } \\
\text {-Gender } \\
\text {-Age }\end{array}$ & $\begin{array}{l}\text {-On-the-job } \\
\text { search } \\
\text {-Training } \\
\text { participation } \\
\text {-Occupational } \\
\text { status }\end{array}$ \\
\hline 5 & $\begin{array}{l}\text { Robst } \\
(2007 a)\end{array}$ & United States & $\begin{array}{l}\text { National Survey of } \\
\text { College Graduates } \\
\text { (NSCG) from the } \\
\text { National Science } \\
\text { Foundation- cross } \\
\text { sectional - } 1993\end{array}$ & $\begin{array}{l}\text { Nationally } \\
\text { representative sample } \\
\text { of individuals in the } \\
\text { United States who } \\
\text { indicated on the } 1990 \\
\text { Census to have attained } \\
\text { at least a bachelor's } \\
\text { degree (final sample: } n \\
=124,063 \text { ). }\end{array}$ & $\begin{array}{l}\text {-Ordered logit } \\
\text { regression: } \\
\text { determinants } \\
\text {-OLS regression: } \\
\text { effects }\end{array}$ & $\begin{array}{l}\text {-Field-of-study } \\
\text {-Level of education } \\
\text {-Gender } \\
\text {-Age } \\
\text {-Ethnicity } \\
\text {-Having a disability } \\
\text {-Marital status }\end{array}$ & Wage \\
\hline 6 & $\begin{array}{l}\text { Robst } \\
(2007 b)\end{array}$ & United States & $\begin{array}{l}\text { National Survey of } \\
\text { College Graduates } \\
\text { (NSCG) from the } \\
\text { National Science } \\
\text { Foundation- cross } \\
\text { sectional - } 1993\end{array}$ & $\begin{array}{l}\text { Nationally } \\
\text { representative sample } \\
\text { of individuals in the } \\
\text { United States who have } \\
\text { attained at least a } \\
\text { bachelor's degree (final } \\
\text { sample: } \mathrm{n}=124,063 \text { ) }\end{array}$ & $\begin{array}{l}\text {-Logit regression: } \\
\text { determinants } \\
\text {-OLS regression: } \\
\text { effects }\end{array}$ & $\begin{array}{l}\text { Robst (2007a) uses the same dataset } \\
\text { and includes the same regressors. } \\
\text { Footnotes in the text report when } \\
\text { different coefficients were obtained for } \\
\text { these variables. }\end{array}$ & Wage \\
\hline
\end{tabular}


Appendix 2.1 (continued)

\begin{tabular}{|c|c|c|c|c|c|c|c|}
\hline & $\begin{array}{l}\text { Author } \\
\text { (year of } \\
\text { pub.) }\end{array}$ & Country of study & $\begin{array}{l}\text { Data source, type of } \\
\text { data and year of data } \\
\text { collection }\end{array}$ & Sample population & Statistical method & $\begin{array}{l}\text { Determinants of horizontal } \\
\text { mismatch }\end{array}$ & $\begin{array}{l}\text { Effects of } \\
\text { horizontal } \\
\text { mismatch }\end{array}$ \\
\hline 7 & $\begin{array}{l}\text { Hensen et } \\
\text { al. (2009) }\end{array}$ & The Netherlands & $\begin{array}{l}\text { Two surveys from the } \\
\text { Research Centre for } \\
\text { Education and the } \\
\text { Labour Market } \\
\text { (ROA): Registration } \\
\text { of Outflow and } \\
\text { Destination of } \\
\text { Graduates (RUBS) } \\
\text { and HBO-monitor - } \\
\text { time series - 1996- } \\
2001\end{array}$ & $\begin{array}{l}\text { Individuals aged 16-30 } \\
\text { years, surveyed } 18 \\
\text { months after } \\
\text { graduation, who } \\
\text { attended full-time pre-, } \\
\text { secondary or higher } \\
\text { vocational education } \\
\text { and are in paid } \\
\text { employment (final } \\
\text { sample: } \mathrm{n}=83,239) \text {. }\end{array}$ & $\begin{array}{l}\text { Logistic regression: } \\
\text { determinants }\end{array}$ & $\begin{array}{l}\text {-Field-of-study } \\
\text {-Level of education } \\
\text {-State of the economy } \\
\text {-Job density* } \\
\text {-Gender } \\
\text {-Age } \\
\text {-Ethnicity } \\
\text {-Job mobility }\end{array}$ & \\
\hline 8 & $\begin{array}{l}\text { Cosser } \\
(2010)\end{array}$ & South Africa & $\begin{array}{l}\text { Research Programme } \\
\text { on Human Resources } \\
\text { Development (HRD) } \\
\text { - time series - 2001, } \\
\text { 2002, } 2006\end{array}$ & (Final sample: 496,120). & Descriptive analysis & & \\
\hline 9 & $\begin{array}{l}\text { Malamud } \\
(2010)\end{array}$ & $\begin{array}{l}\text { England and } \\
\text { Scotland }\end{array}$ & $\begin{array}{l}\text { Survey of British } \\
\text { Department of } \\
\text { Employment: } 1980 \\
\text { National Survey of } \\
\text { Graduates and } \\
\text { Diplomates (NSGD) - } \\
\text { cross sectional - } \\
\text { 1986/1987 }\end{array}$ & $\begin{array}{l}\text { Scottish and English } \\
\text { university graduates } \\
\text { who obtained a BA } \\
\text { degree in } 1980 \text { and were } \\
\text { employed full-time in } \\
\text { the first year after } \\
\text { graduation (final sample } \\
\text { NSGD: } \mathrm{n}= \pm 4,800 \text { ). }\end{array}$ & $\begin{array}{l}\text { OLS regression: } \\
\text { effects }\end{array}$ & $\begin{array}{l}\text { Malamud (2011) uses the same } \\
\text { dataset and also examines the effect } \\
\text { of the timing of academic } \\
\text { specialization on horizontal } \\
\text { mismatch. Results were similar. }\end{array}$ & $\begin{array}{l}\text {-Wage } \\
\text {-Annual } \\
\text { earnings } \\
\text { growth* } \\
\text {-On-the-job } \\
\text { search } \\
\text { - Getting an } \\
\text { interesting } \\
\text { job }\end{array}$ \\
\hline 10 & $\begin{array}{l}\text { Mora } \\
(2010)\end{array}$ & Spain & $\begin{array}{l}\text { The Quality } \\
\text { Assurance Agency for } \\
\text { seven public } \\
\text { universities in } \\
\text { Catalonia - cross- } \\
\text { sectional - } 2000\end{array}$ & $\begin{array}{l}1997 / 98 \text { graduates aged } \\
23-33 \text { years from one } \\
\text { of the seven public } \\
\text { Catalan universities } \\
\text { (final sample } \mathrm{n}>3500 \text { ) }\end{array}$ & $\begin{array}{l}\text { Probit regression } \\
\text { and two-step probit } \\
\text { regressions with } \\
\text { endogenous } \\
\text { regressor }\end{array}$ & & $\begin{array}{l}\text { Study } \\
\text { programme } \\
\text { regret }\end{array}$ \\
\hline
\end{tabular}


Appendix 2.1 (continued)

\begin{tabular}{|c|c|c|c|c|c|c|c|}
\hline & $\begin{array}{l}\text { Author } \\
\text { (year of } \\
\text { pub.) }\end{array}$ & $\begin{array}{l}\text { Country of } \\
\text { study }\end{array}$ & $\begin{array}{l}\text { Data source, type of data } \\
\text { and year of data collection }\end{array}$ & Sample population & Statistical method & $\begin{array}{l}\text { Determinants of horizontal } \\
\text { mismatch }\end{array}$ & $\begin{array}{l}\text { Effects of } \\
\text { horizontal } \\
\text { mismatch }\end{array}$ \\
\hline 11 & $\begin{array}{l}\text { Nordin et } \\
\text { al. }(2010)\end{array}$ & Sweden & $\begin{array}{l}\text { Data from Swedish } \\
\text { Register of Education } \\
\text { (UREG) and income data } \\
\text { of National Tax Board } \\
\text { were added to register of } \\
\text { the total population (RTB) } \\
\text { - cross-sectional - } 2003\end{array}$ & $\begin{array}{l}\text { Swedish-born } \\
\text { individuals aged 28-39, } \\
\text { with a college } \\
\text { /university degree (final } \\
\text { sample men: } \mathrm{n}= \\
\text { 67,607; final sample } \\
\text { females: } \mathrm{n}=116,750 \text { ) }\end{array}$ & $\begin{array}{l}\text { OLS regression: } \\
\text { wage effects }\end{array}$ & & Wage \\
\hline 12 & $\begin{array}{l}\text { Yakusheva } \\
(2010)\end{array}$ & United States & $\begin{array}{l}\text { Survey conducted by the } \\
\text { U.S. department of } \\
\text { education: High School } \\
\text { and Beyond (HS\&B) - } \\
\text { longitudinal } \\
\text { 1982,1984,1986, } 1992\end{array}$ & $\begin{array}{l}\text { Sample of } 1980 \text { high } \\
\text { school sophomores } \\
\text { with some post- } \\
\text { secondary education ( } 4 \\
\text { years at most) (final } \\
\text { sample: } \mathrm{n}=2,268 \text { ). }\end{array}$ & $\begin{array}{l}\text { OLS regression: } \\
\text { wage effects }\end{array}$ & & Wage \\
\hline 13 & $\begin{array}{l}\text { Béduwé \& } \\
\text { Giret } \\
(2011)\end{array}$ & France & $\begin{array}{l}\text { Generation } 98 \text { survey - } \\
\text { cross-sectional - } 2001\end{array}$ & $\begin{array}{l}\text { Secondary vocational } \\
\text { educ. graduates and first } \\
\text { level of higher } \\
\text { education, } 3 \text { years after } \\
\text { graduation (final } \\
\text { sample: } \mathrm{n}=21,780 \text { ). }\end{array}$ & $\begin{array}{l}\text {-OLS regression: } \\
\text { wage effects } \\
\text {-Probit regression: } \\
\text { effect on on-the- } \\
\text { job search and job } \\
\text { satisfaction }\end{array}$ & & $\begin{array}{l}\text {-Wage } \\
\text {-On-th -job } \\
\text { search } \\
\text {-Job } \\
\text { satisfaction }\end{array}$ \\
\hline 14 & $\begin{array}{l}\text { Bender \& } \\
\text { Heywood } \\
(2011)\end{array}$ & United States & $\begin{array}{l}\text { Survey of Doctorate } \\
\text { Recipients (SDR) - panel - } \\
\text { 1993,1995, } \\
1997,1999,2001,2003 \text { and } \\
2006\end{array}$ & $\begin{array}{l}\text { PhD graduates in a } \\
\text { (hard or social) science, } \\
\text { math, or engineering } \\
(\mathrm{SME}) \text { field and who } \\
\text { reside in the United } \\
\text { States (final sample }> \\
200,000) .\end{array}$ & $\begin{array}{l}\text {-Descriptive } \\
\text { analysis: } \\
\text { determinants } \\
\text {-Fixed effects } \\
\text { regression: effects }\end{array}$ & $\begin{array}{l}\text {-Field-of-study } \\
\text {-Sector } \\
\text {-Gender } \\
\text {-Age } \\
\text {-Disability } \\
\text {-Naturalized citizen* } \\
\text {-Noncitizen vs. noncitizen* }\end{array}$ & Wage \\
\hline
\end{tabular}

-Naturalized citizen*
-Noncitizen vs. noncitizen* 
Appendix 2.1 (continued)

\begin{tabular}{|c|c|c|c|c|c|c|c|}
\hline & $\begin{array}{l}\text { Author } \\
\text { (year of } \\
\text { pub.) }\end{array}$ & $\begin{array}{l}\text { Country } \\
\text { of study }\end{array}$ & $\begin{array}{l}\text { Data source, type of } \\
\text { data and year of data } \\
\text { collection }\end{array}$ & Sample population & 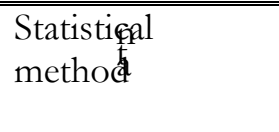 & Determinants of horizontal mismatch & $\begin{array}{l}\text { Effects of } \\
\text { horizontal } \\
\text { mismatch }\end{array}$ \\
\hline 15 & $\begin{array}{l}\text { Farooq } \\
(2011)\end{array}$ & Pakistan & $\begin{array}{l}\text { Survey of Employed } \\
\text { Graduates (SEG) and } \\
\text { Labour Force Survey } \\
\text { (LFS) - time series - } \\
2010 \text { (SEG) and } \\
2006 / 2007,2008 / 2009 \\
(\text { LFS) }\end{array}$ & $\begin{array}{l}\text { Employed graduates } \\
\text { working in the formal } \\
\text { sector with a } \\
\text { Bachelor's, Master's or } \\
\text { doctoral degree (final } \\
\text { sample: } \mathrm{n}=513 \text { ). }\end{array}$ & $\begin{array}{l}\text { Logistic } \\
\text { regression: } \\
\text { determinants }\end{array}$ & $\begin{array}{l}\text {-Field-of-study } \\
\text {-Level of education } \\
\text {-Time devoted to studies } \\
\text {-Occupational group } \\
\text {-Gender } \\
\text {-Socioeconomic background * } \\
\text {-Annual vs. semester system* }\end{array}$ & \\
\hline 17 & $\begin{array}{l}\text { Boudarbat } \\
\text { \& Chernoff } \\
(2012)\end{array}$ & Canada & $\begin{array}{l}\text { Follow up of Canadian } \\
\text { Graduates - Class of } \\
2000 \text { survey - cross- } \\
\text { section - } 2005\end{array}$ & $\begin{array}{l}\text { University graduates } \\
\text { (Bachelor and beyond), } \\
5 \text { years after graduation } \\
\text { (final sample: } \mathrm{n}= \\
9,335 \text { ) }\end{array}$ & $\begin{array}{l}\text { Logit regression: } \\
\text { determinants }\end{array}$ & $\begin{array}{l}\text {-Field-of-study } \\
\text {-Level of education } \\
\text {-Activities before university } \\
\text {-Time devoted to studies } \\
\text {-Type of contract } \\
\text {-Method to obtain job } \\
\text {-Gender } \\
\text {-Age } \\
\text {-Ethnicity } \\
\text {-Parental education } \\
\text {-Ability (grades) } \\
\text {-Family wealth* }\end{array}$ & \\
\hline
\end{tabular}


Appendix 2.1 (continued)

\begin{tabular}{|c|c|c|c|c|c|c|c|}
\hline & $\begin{array}{l}\text { Author } \\
\text { (year of } \\
\text { pub.) }\end{array}$ & Country of study & $\begin{array}{l}\text { Data source, type of } \\
\text { data and year of data } \\
\text { collection }\end{array}$ & Sample population & Statistical method & $\begin{array}{l}\text { Determinants of horizontal } \\
\text { mismatch }\end{array}$ & $\begin{array}{l}\text { Effects of } \\
\text { horizontal } \\
\text { mismatch }\end{array}$ \\
\hline 18 & $\begin{array}{l}\text { Kucel \& } \\
\text { Vilalta-Bufí } \\
(2012)\end{array}$ & Poland & $\begin{array}{l}\text { HEGESCO survey } \\
\text { for Poland - cross- } \\
\text { section - } 2008\end{array}$ & $\begin{array}{l}\text { Graduates who received } \\
\text { their bachelor's or } \\
\text { master's degree } \\
\text { (ISCED5A) in } \\
\text { 2002/2003. Self- } \\
\text { employed and part-time } \\
\text { employees are excluded. } \\
\text { (final sample: } \mathrm{n}=692 \text { ) }\end{array}$ & $\begin{array}{l}\text { Logistic regression: } \\
\text { determinants }\end{array}$ & $\begin{array}{l}\text {-Field-of-study } \\
\text {-Level of education } \\
\text {-Vocational education } \\
\text {-Internship during studies } \\
\text {-Prestige of university } \\
\text {-Employers' familiarity with } \\
\text { programme } \\
\text {-Difficulty programme* } \\
\text {-Freedom to compose study } \\
\text { programme* } \\
\text {-Broadness study programme* } \\
\text {-Job tenure } \\
\text {-Firm size } \\
\text {-Gender } \\
\text {-Age } \\
\text {-Ability (grades) } \\
\text {-Possessed competencies* }\end{array}$ & \\
\hline 19 & $\begin{array}{l}\text { Bender \& } \\
\text { Roche } \\
(2013)\end{array}$ & United States & $\begin{array}{l}\text { Dataset from the US } \\
\text { National Science } \\
\text { Foundation (NSF): } \\
\text { National Survey of } \\
\text { College Graduates } \\
\text { (NSCG) - cross- } \\
\text { section - } 2003\end{array}$ & $\begin{array}{l}\text { Employees with at least } \\
\text { a bachelor's degree in a } \\
\text { hard or social science, } \\
\text { technology, engineering, } \\
\text { or mathematics (STEM) } \\
\text { field (final sample: } \mathrm{n}= \\
74,229 \text { ) }\end{array}$ & $\begin{array}{l}\text {-Ordered probit: } \\
\text { determinants } \\
\text {-OLS: wage effects } \\
\text {-Ordered probit: } \\
\text { effect on job } \\
\text { satisfaction }\end{array}$ & $\begin{array}{l}\text {-Level of education } \\
\text {-Occupational group } \\
\text {-Gender } \\
\text {-Age } \\
\text {-Ethnicity } \\
\text {-Marital status } \\
\text {-US citizenship* }\end{array}$ & $\begin{array}{l}\text {-Wage } \\
\text {-Job } \\
\text { satisfaction }\end{array}$ \\
\hline 20 & $\begin{array}{l}\text { Kucel \& } \\
\text { Vilalta-Bufí } \\
(2013)\end{array}$ & $\begin{array}{l}\text { Spain and } \\
\text { Netherlands }\end{array}$ & $\begin{array}{l}\text { REFLEX survey data } \\
\text { - cross-section - } 2005\end{array}$ & $\begin{array}{l}\text { 1999/2000 Tertiary } \\
\text { graduates (final sample } \\
\text { Spain: } \mathrm{n}=2,777 \\
\text { Netherlands: } \mathrm{n}=2,683 \text { ) }\end{array}$ & $\begin{array}{l}\text { Logistic regression: } \\
\text { effect on study } \\
\text { programme regret }\end{array}$ & & $\begin{array}{l}\text { Study } \\
\text { programme } \\
\text { regret }\end{array}$ \\
\hline
\end{tabular}


Appendix 2.1 (continued)

\begin{tabular}{|c|c|c|c|c|c|c|c|}
\hline & $\begin{array}{l}\text { Author } \\
\text { (year of } \\
\text { pub.) }\end{array}$ & $\begin{array}{l}\text { Country of } \\
\text { study }\end{array}$ & $\begin{array}{l}\text { Data source, type of } \\
\text { data and year of data } \\
\text { collection }\end{array}$ & Sample population & $\underset{\substack{t \\
\text { Statistical method }}}{\text { Sal }}$ & $\begin{array}{l}\text { Determinants of horizontal } \\
\text { mismatch }\end{array}$ & $\begin{array}{l}\text { Effects of } \\
\text { horizontal } \\
\text { mismatch }\end{array}$ \\
\hline 21 & $\begin{array}{l}\text { Levels et al. } \\
(2014)\end{array}$ & 20 countries $^{b}$ & $\begin{array}{l}\text { European Union } \\
\text { Labour Force Survey } \\
2009 \text { Ad Hoc Module } \\
\text { (EU LFS 2009) - } \\
\text { cross-sectional - } 2009\end{array}$ & $\begin{array}{l}\text { Individuals aged 15-34 } \\
\text { years with upper- } \\
\text { secondary and post- } \\
\text { secondary education who } \\
\text { graduated between } 1989- \\
2009 \text {. (final sample: } \mathrm{n}= \\
30,805 \text { ) }\end{array}$ & $\begin{array}{l}\text { Multi-level logistic } \\
\text { regression: } \\
\text { determinants }\end{array}$ & $\begin{array}{l}\text {-Vocational education } \\
\text {-Vocational orientation } \\
\text { education system } \\
\text {-Strength institutional linkages } \\
\text {-Standardization of curricula } \\
\text { and outcomes* }\end{array}$ & \\
\hline 22 & $\begin{array}{l}\text { Robert } \\
(2014)\end{array}$ & $\begin{array}{l}\text { Hungary, } \\
\text { Poland, } \\
\text { Lithuania and } \\
\text { Slovenia }\end{array}$ & $\begin{array}{l}\text { HEGESCO survey, } \\
\text { follow-up of } \\
\text { REFLEX project } \\
\text { (same questionnaire) - } \\
\text { cross-sectional } \\
2008 / 2009\end{array}$ & $\begin{array}{l}\text { Individuals who } \\
\text { graduated five years } \\
\text { before in } 2002 / 2003 \\
\text { (final sample: } \mathrm{n}=6,665 \text { ) }\end{array}$ & $\begin{array}{l}\text { Logistic regression: } \\
\text { determinants }\end{array}$ & $\begin{array}{l}\text {-Field-of-study } \\
\text {-Work-based experience } \\
\text {-Job search duration } \\
\text {-Type of contract } \\
\text {-Gender } \\
\text {-Age } \\
\text {-Job mobility } \\
\text {-Parental education }\end{array}$ & \\
\hline 23 & Zhu (2014) & China & $\begin{array}{l}2008 \text { Chinese College } \\
\text { Graduates' } \\
\text { Employment and } \\
\text { Work Skills Survey - } \\
\text { cross-sectional-2008 }\end{array}$ & $\begin{array}{l}2007 \text { Graduates from } 43 \\
\text { 4-year colleges in the } \\
\text { Shandong province } 6-12 \\
\text { months before survey (n } \\
=5,879 \text { ) }\end{array}$ & $\begin{array}{l}\text { OLS regression and } \\
\text { nonparametric local } \\
\text { linear kernel } \\
\text { estimation: wage } \\
\text { effects }\end{array}$ & & Wage \\
\hline 24 & $\begin{array}{l}\text { Shevchuk } \\
\text { et al. (2015) }\end{array}$ & Russia & $\begin{array}{l}\text { Online questionnaire } \\
\text { conducted by the } \\
\text { authors - cross- } \\
\text { sectional - } 2011\end{array}$ & $\begin{array}{l}\text { Russian-languange } \\
\text { internet freelancers with a } \\
\text { completed tertiary degree } \\
\text { (final sample men: } \mathrm{n}= \\
918 \text {; women } \mathrm{n}=684 \text { ) }\end{array}$ & $\begin{array}{l}\text {-Ordered probit: } \\
\text { effect on wage and } \\
\text { job satisfaction } \\
\text {-Logistic regression: } \\
\text { effect on job search }\end{array}$ & & $\begin{array}{l}\text {-Wage } \\
\text {-On-the-job } \\
\text { search } \\
\text {-Job } \\
\text { satisfaction }\end{array}$ \\
\hline
\end{tabular}

Notes: * indicates that this variable was examined by only one study and no significant effect was found. a. Wave 1987 is used to estimate the incidence and determinants of horizontal match. As a robustness check, cross-sectional logistic regressions were estimated separately for each year from 1984 to 1990 . The estimated coefficients were consistent over the years. The wage regressions were estimated on the monthly gross earnings of 1984 . b. Austria, Belgium, Czech Republic, Germany, Denmark, Spain, Finland, France, Greece, Hungary, Ireland, Italy, Luxembourg, the Netherlands, Norway, Poland, Sweden, Slovenia, Slovak Republic and the U.K. c. The 18 countries comprise Austria, Belgium (Flanders), Czech Republic, Estonia, Finland, France, Germany, Hungary, Italy, the Netherlands, Norway, Poland, Portugal, Slovakia, Spain, Switzerland and the U.K. 


\section{Appendix 2.2: Strategy used in computerized databases search}

ERIC [DECEMBER 2015]

- Keywords: "fit OR match OR mismatch" AND “college OR education OR major OR program OR study” AND “employment OR job OR labor OR labour OR occupation OR work" AND "field" + pubyear:1995

- Limit results to "Peer reviewed only"

EBSCOhost EconLit [DECEMBER 2015]

- Keyword: “fit OR match OR mismatch" AND “college OR education OR major OR program OR study" AND “employment OR job OR labor OR labour OR occupation OR work" AND "field"

- Limit to: "January 1995" to "December 2015" within "Select a Field (optional)"

- Source types: "Academic Journals"

- Language: "English"

EBSCOhost SocINDEX [DECEMBER 2015]

- Keyword: “fit OR match OR mismatch" AND “college OR education OR major OR program OR study" AND "employment OR job OR labor OR labour OR occupation OR work" AND "field" within "Select a Field (optional)"

- Limit to: "Scholarly (Peer Reviewed) Journals', “January 1995” to "December 2015"

- Language: "English" 



\section{Chapter 3}

\section{Mismatch Between Education and the Labour Market in the Netherlands: Is it a Reality or a Myth? The Employers' Perspective ${ }^{12,13,14}$}

12 This study is based on: Cabus, S. J., \& Somers, M. A. (2018). Mismatch between education and the labour market in the Netherlands: is it a reality or a myth? The employers' perspective. Studies in Higher Education, 43(11), 1854-1867. https://doi.org/10.1080/03075079.2017.1284195

13 This study benefitted from discussions with TIER seminar participants, participants of the XXIV Meeting of the Economics of Education Association, participants of the $13^{\text {th }}$ Belgian Day for Labour Economists, participants of the $6^{\text {th }}$ International Workshop on Applied Economics of Education, participants of the $28^{\text {th }}$ European Association of Labour Economists Conference, participants of the GSBE seminar on The Development and Utilization of Human Resources (DUHR), and participants of the Second Workshop on Education Economics.

${ }^{14}$ This study was financially supported by Stichting Instituut Gak under grant [2014-533]. Stichting Instituut Gak was not involved in the preparation of this chapter. 
Chapter 3

\begin{abstract}
This study examines whether the expansion of higher education over the past 20 years has contributed to better education-job matches in the labour market. In particular, changes in the average formal schooling level of workers on the regional labour market relate to the educational attainment of the recruited staff within companies operating on that regional labour market. Companies most often recruit from a pool of workers available on the regional labour market. Next, we estimate how changes in the level of schooling of the staff owing to the increased supply of more highly educated graduates on the regional labour market might affect mismatch. Data from the Dutch Labour Demand Panel are used covering 7,451 unique companies over the period 1991-2011. The results indicate that a one-month increase in the average schooling of a company's workforce decreases the probability that the company will report mismatch by 3.0 percentage points.
\end{abstract}




\subsection{Introduction}

Many OECD countries have witnessed a continued rise in the supply of tertiary education graduates over the recent decades (Autor et al., 1998; Goos et al., 2009; OECD, 2014). The higher education expansion coincided with a significant increase in public investments in education and has raised several questions concerning its implications for the labour market (OECD, 2014). One of the consequences potentially brought forth by this expansion pertains to a mismatch between the skill supply and skill demand in the labour market. While various studies propose that the developments in higher education have resulted in an over-supply of college graduates (e.g. Di Pietro \& Urwin, 2006; Hartog, 2000; Mason, 1996), ample evidence points out that the supply of high skilled workers failed to keep pace with the demand for skilled labour (Bound \& Johnson, 1992; Katz \& Murphy, 1992). Conclusions in the labour market implications of the expansion of tertiary education therefore remain inconclusive and mostly limited to the perspective of employees (see e.g. Groot \& Maasen van den Brink, 2000; McGuinness, 2006). Consequently, the overall picture we have on mismatch may be biased, or at least incomplete.

This chapter provides a different perspective on the implications of the higher education expansion and examines whether employers have benefitted from the increased supply of high-skilled graduates. We explore how employers' perception on the (mis-) match between skill demand and skill supply within their companies has developed over the last two decades and link this to the educational attainment of companies' workforce. Our analyses are performed for the Netherlands that like most other OECD countries has witnessed a growing number of enrolments in higher education as well as an increase in public expenses on education (Van den Berge \& Ter Weel, 2015; CBS, 2011; Jacobs \& Webbink, 2006; Leuven \& Oosterbeek, 2000; OECD, 2014). Hence, the Netherlands provides an interesting case study to explore the consequences of the higher education expansion beyond the perspective of employees.

Only a small number of studies have attempted to evaluate the consequences of the increased supply of skilled labour from the perspective of employers (Belfield, 2010; Büchel, 2002; Kampelmann \& Rycx, 2012; Tsang, 1987; Tsang, Rumberger \& Levin, 1991). These studies have investigated through various approaches how firm productivity is affected by the presence of employees whose acquired level of education exceeds the required level for the job. One approach relies on standard human capital theory and derives productivity effects of over-education from workers' wages. This approach argues that over-qualified workers are more productive than their well-matched colleagues as over-educated workers generally receive a wage premium over their adequately allocated 
colleagues (e.g. Groot \& Maasen van den Brink, 2000; Rumberger, 1987). Other studies have examined the effect of over-education on productivity-related factors such as job satisfaction and job turnover and found mixed results. While some studies found a negative relation between over-education and job satisfaction (Belfield, 2010; Hersch, 1991; Tsang, 1987; Verhaest \& Omey, 2009), other studies did not find that overeducated workers report lower levels of job satisfaction in comparison to their wellmatched colleagues (Büchel, 2002; Verhaest \& Omey, 2006). Regarding job turnover, Hersch (1991) and Tsang, Rumberger and Levin (1991) provided evidence that the turnover rate is higher among over-qualified male workers, whereas Büchel (2002) indicated that over-educated workers show longer firm tenure than their adequately educated colleagues. Only a few studies attempted to estimate the impact of overqualification on direct measures of firm productivity. Tsang (1987) showed that overeducation is negatively and significantly related to job satisfaction which is in turn positively and significantly related to firm output. In contrast, a more recent study of Kampelmann and Rycx (2012) found that additional years of over-qualification have a positive effect on firm productivity.

The contribution of this study to the literature is twofold. Our study is the first to examine how the match between job requirements and employees' skills has evolved over time according to employers. Doing so, this study is also the first to provide a measure of mismatch that is based on employer reports. The analyses are based on data from the Dutch Labour Demand Panel consisting of 11,817 observations from 7,451 unique companies between 1991 and 2011. Due to the richness of the collected data, this chapter presents an overall and representative picture of mismatch from the employers' perspective.

The second contribution concerns our methodology. The composition of companies' workforce heavily relies on the endogenous recruitment process (Caldwell \& O'Reilly, 1990). Due to endogeneity issues, direct estimates of the effect of an increase in formal education within companies on mismatch only allow for a correlational interpretation. However, prior research proposes that graduates' educational attainment on the regional labour market can be considered a public good for a company operating within that region (Moretti, 2004; Rauch, 1993; Tilak, 2008). An employer who seeks a good match with his vacancies heavily relies on the availability of workers in the area wherein business activities take place. In other words, the employer takes the worker availability within the regional labour market as given (i.e. exogenous), while the selection of workers into the company is endogenous. We take advantage of the consecutive steps an employer takes to hire a worker (worker availability-recruitment-mismatch) by performing our analyses in two steps: (1) we relate the average formal schooling level of the regional labour force 
to the average schooling level of the recruited staff within companies operating on that regional labour market; and (2) we estimate the effect of changes in the schooling level of the staff owing to the increase of highly educated graduates on the regional labour market on mismatch. This approach is similar to the instrumental variables method (Angrist, Imbens \& Rubin, 1996). In this chapter, individuals' educational attainment is defined as the total years in formal education. Given that we focus on the relation between the increased supply of skilled labour and the match between employees' skills and job requirements, our definition of educational attainment excludes other forms of human capital such as job training and work experience. However, we do consider other elements of individuals' educational attainment as an important direction for future research. ${ }^{15}$

The remainder of this chapter proceeds as follows. The next section discusses the endogeneity issues regarding the educational composition of companies' workforce and addresses how we deal with those issues. The data section describes the datasets on which the analyses are based and presents descriptive statistics. Next, this chapter introduces the empirical framework and shows the results. This chapter ends with a conclusion and a discussion of the results.

\subsection{Endogenous recruitment process}

The educational composition of a company's workforce is determined by the endogenous recruitment process of the company. The selection of employees is not only based on the perceived match of employees' skills with the job requirements, but also with firm strategies that are heterogeneous across companies (Chatman, 1991). Firm characteristics that determine the educational composition of its workforce are often unobservable in empirical analyses and may concern human resource management strategies or specific skill needs. For instance, Bartel (1994) showed that workplace training is mostly received by highly educated workers and is more likely to take place in technologically progressive industries. Moreover, technologies can be skill complementary and favour certain type of workers (e.g. Autor et al., 1998; Bartel \& Lichtenberg, 1987; Machin \& Van Reenen, 1998). Companies also decide whether to acquire certain skills and competences on the market or to develop them internally (Cappelli, 2008). Hence, companies sort themselves

\footnotetext{
15 One would also have to find additional valid instruments for job training and work experience in order to obtain unbiased estimates of the effects of these forms of educational attainment on mismatch. Based on the skill needs of the company, employers determine endogenously how much work experience their employees have through the recruitment process and how much and which types of training their employees should receive.
} 
non-randomly into specific employee-company matches which, eventually, lead to different workforce compositions.

We exploit information on the average years in formal schooling of graduates available on the (regional) labour market to create exogenous variation in the average years of schooling attained by companies' employees. From the worker's perspective, employment opportunities mainly arise at the regional level due to restricted spatial flexibility (Van Ham, Hooimeijer \& Mulder, 2001). The likelihood that employed individuals in the Netherlands search for another job or accept a job offer increases with restricted commuting time (Van Ommeren, Rietveld \& Nijkamp, 1998). Therefore, companies are likely to draw their workforce from the pool of workers available on the regional labour market (Van Ham et al., 2001). The empirical literature confirms that the job location is indeed one of the most important reasons for individuals to accept as well as to reject a job offer (Boswell et al., 2003).

Moreover, we instrument the formal schooling of companies' workforce at time $t$ with the formal schooling of the regional labour force in $t-1$. The timing of graduation and job arrival does often not occur simultaneously (Van Ours \& Ridder, 1992). Workers are heterogeneous in terms of the skills they possess and the skill requirements differ across firms (Pissarides, 2000). Furthermore, the location of the demand for certain skills does not always coincide with the location of the supply of these skills (Pissarides, 2000). Consequently, it takes time and other resources for a worker to find a good job with an adequate wage, and for a firm to find a proper match between a vacancy and a worker (Rogerson et al., 2005; Stigler, 1962). Provided that labour markets do not clear automatically, changes in the composition of the labour force are reflected in changes in companies' workforce only after some amount of time.

The educational composition of the regional labour force can be treated as an exogenous supply of labour from the perspective of a single company as educational choices are made at the individual level (Moretti, 2004; Rauch, 1993; Tilak, 2008). Early research already pointed at the economic theory that individuals make their human capital investment decisions according to their expected present value of education (Becker, 1994; Mincer, 1974). In addition, educational choices follow from information on the individual's ability, personality and occupational preferences (Holland, Gottfredson \& Power, 1980; Weiss, 1972). Moreover, while our instrument is argued to be a good predictor of the endogenous regressor, it is unlikely to directly affect mismatch. Our outcome variable is derived from employers' perception on the degree to which employees adequately perform their job. The educational attainment of workers in the local labour force can only affect perceived mismatch if a company actually recruits 
workers from the regional labour market and reflects on the skills possessed by those workers. Hence, our instrument only indirectly influences mismatch through the endogenous recruitment process of the company.

However, considering the increase in the share of highly educated graduates in the Netherlands as exogenous to the company, we must exclude that companies select their location due to expected gains from available levels of human capital. This assumption implies that companies do not relocate to areas that supply the desirable levels of schooling according to their needs. Our data show that during the sample period almost 99 percent of the companies in our sample did not relocate (see section "Control variables"). Furthermore, the longer companies have been in a region, the less likely it becomes that those companies have been able to predict the supply of human capital in this region. As the results section will demonstrate, our estimates remain unchanged once we account for location sorting behaviour.

\subsection{Data and descriptive statistics}

\subsubsection{Labour demand}

The analyses are based on data from the Dutch Labour Demand Panel (Arbeidsvraagpanel) and the Dutch Labour Supply Panel (Arbeidsaanbodpanel) which are available at the Netherlands Institute for Social Research (www.scp.nl). The Labour Demand Panel survey is conducted biannually among Dutch employers and contains information on the composition of the workforce and employees' competencies. The dataset covers the period 1991-2011. On average, companies participated twice in the survey, yielding 33,601 observations. About 26,530 employers answered the question on mismatch which was formulated as: 'In your opinion, is your workforce sufficiently equipped to meet the job task requirements of the coming years?' As from 2003, this question slightly changed to: 'In your opinion, is your workforce not sufficiently equipped to meet the job task requirements of the coming years?' The answers were coded into a binary variable, taking the value ' 1 ' if the answer was 'mismatch, not sufficiently equipped', and ' 0 ' if the answer was 'no mismatch, sufficiently equipped'. ${ }^{16}$ The mismatch question was not included in the year 1995.

About 17,498 employers (52 percent) indicated the share of employees whose highest level of education fell into each of the following categories of Dutch diplomas: (1) university $(w o)$ or higher professional education $(b b o)$, (2) vocational education (mbo),

16 We test whether the parameter for mismatch on year is constant before and after 2003. The $\mathrm{F}$ statistic of the chow test for structural breaks yields $11.22(p=.000)$. Hence, we have to reject the hypothesis of stable coefficients. However, we do not observe any abrupt change in the mismatch pattern after 2001 and therefore conclude that the change in the mismatch question is not a concern. 
general secondary education (havo) or pre-university education (vwo), (3) pre-vocational secondary education (vmbo) and (4) primary education. Based on the nominal study duration of each level of education, we translated the educational attainment of companies' staff into average months as well as into years in formal schooling. After removing the observations with missing answers on the variables included in our analyses, our sample size is reduced to 11,817 observations (7,451 unique companies). ${ }^{17}$ Table 3.1 shows that the average mismatch rate between 1991 and 2011 is 31.2 percent when no survey weights are used and 27.7 percent when survey weights are used. For the remaining analyses in this chapter, the samples are always weighted in order to obtain a better representation of the population from which companies were drawn. The average years of schooling equals 13.4 years (or 160.5 months). A large pool of workers (32 percent vmbo; and 7.7 percent only primary education) would nowadays be classified as 'school dropouts', that is, individuals without a secondary school-leaving certificate who are not in formal education.

Table 3.1: Summary statistics of the main variables

\begin{tabular}{lccccc}
\hline \hline & $\mathrm{N}$ & Mean & Std.dev. & Min & Max \\
\hline Mismatch & & & & & \\
mismatch $(1=$ yes, $0=$ no) unweighted & 11,817 & 0.312 & 0.463 & 0 & 1 \\
mismatch (1=yes, $0=$ no) weighted & 11,817 & 0.277 & 0.448 & 0 & 1 \\
Highest educational level attained(1) & & & & & \\
Categories (\%) & & & & & \\
wo; hbo & 11,817 & 24.9 & 17.1 & 0 & 100 \\
mbo; havo; wwo & 11,817 & 35.4 & 30.3 & 0 & 100 \\
Vmbo & 11,817 & 32.0 & 25.8 & 0 & 100 \\
primary education & 11,817 & 7.7 & 29.8 & 0 & 100 \\
Education (in years) & 11,817 & 13.4 & 1.9 & 7 & 20 \\
Education (in months) & 11,817 & 160.5 & 23.0 & 86 & 243 \\
\hline \hline
\end{tabular}

Notes: The categories denote: (1) university (wo) or higher professional education (bbo), (2) vocational education (mbo), general secondary education (havo) or pre-university education ( $v w o$ ), (3) pre-vocational secondary education (vmbo), and (4) only primary education.

The mismatch rates for the period 1991-2011 are plotted on Figure 3.1. The linear trend shows that employers' view on the match between employees' skills and the job requirements significantly improved between 1991 and 2011. In 1991, almost 1 out of every 2 employers reported a degree of mismatch, while in 2011, only about 1 out of every 4 employers did so. There appears to be a cyclical pattern in the share of companies reporting mismatch. To observe this, we have fitted a second order polynomial function

17 A two-sample t-test with equal variances indicates that the un-weighted mismatch rates of the full sample (32.18 percent mismatch) are highly comparable to the reduced sample (31.51 percent mismatch). 
to the data and took 2003, when economic activity in the Netherlands was at its lowest point, as a breaking point.

\section{Figure 3.1: Employers' self-reported mismatch rates (weighted) 1991-2011}

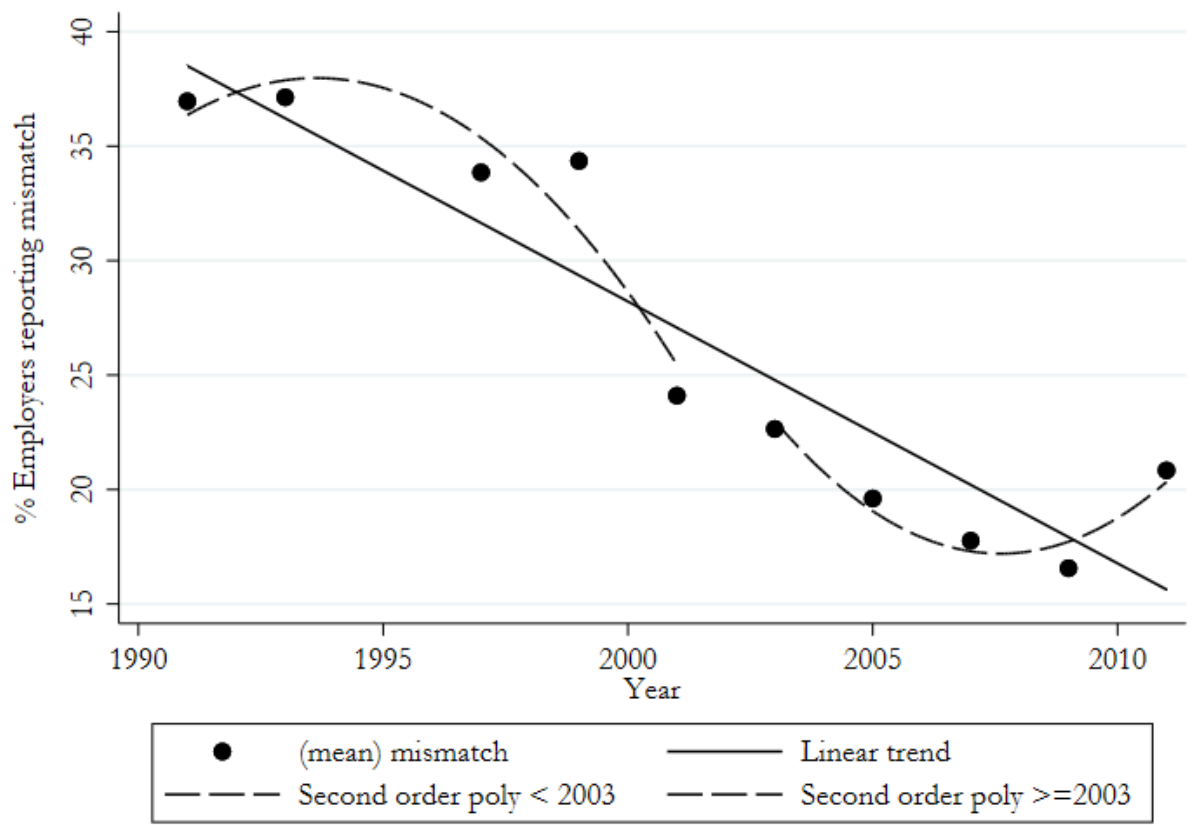

Employers' self-reported mismatch rates are also analysed per sector. While the downward sloping trend is observed for each sector in our dataset, the degree to which companies experience mismatch differs across sectors (Table 3.2). Whereas the transport sector has a historical low rate of mismatch equal to 18.0 percent, the education sector (36.7 percent) and the government sector (42.1 percent) have always been suffering from relatively high rates of mismatch. The downward sloping mismatch trend from 1991 to 2011 is relatively small for the government sector ( -4.0 percent). Regarding the average years of schooling of companies' workforce, one could rank the nine sectors from least attracting to most attracting (Table 3.3). The construction sector would be given rank 1, while the sectors industry and agriculture and transport receive second and third place. The education sector gets rank 9, followed by the sector business services and the government sector. The level of formal schooling increased for each sector, except for the sector other services. 
Table 3.2: Mismatch rates (weighted) 1991-2011 by sector

\begin{tabular}{lcccccc}
\hline \hline Sector & $\mathrm{N}$ & Mean & Std.dev. & 1991 & 2011 & Change \\
\hline Industry \& agriculture & 2,466 & 0.3202 & 0.4667 & 0.4060 & 0.2714 & $-33.15 \%$ \\
Construction & 1,024 & 0.2199 & 0.4144 & 0.2786 & 0.1330 & $-52.27 \%$ \\
Trade, catering, repair & 1,578 & 0.2113 & 0.4083 & 0.3338 & 0.1294 & $-61.22 \%$ \\
Transport & 672 & 0.1798 & 0.3843 & 0.2229 & 0.1798 & $-19.37 \%$ \\
Business services & 1,439 & 0.2573 & 0.4373 & 0.3390 & 0.1990 & $-41.30 \%$ \\
Life sciences \& health & 1,861 & 0.3429 & 0.4748 & 0.4582 & 0.2451 & $-46.51 \%$ \\
Other services & 840 & 0.2217 & 0.4157 & 0.3172 & 0.1855 & $-41.52 \%$ \\
Government & 829 & 0.4212 & 0.4940 & 0.4414 & 0.4236 & $-4.04 \%$ \\
Education & 1,108 & 0.3668 & 0.4821 & 0.4668 & 0.3551 & $-23.91 \%$ \\
\hline \hline
\end{tabular}

Table 3.3: Years in formal education 1991-2011 by sector

\begin{tabular}{lcccccc}
\hline \hline Sector & $\mathrm{N}$ & Mean & Std.dev. & 1991 & 2011 & Change \\
\hline Industry and agriculture & 2,466 & 12.3 & 1.3 & 11.9 & 12.6 & $6.05 \%$ \\
Construction & 1,024 & 12.1 & 1.3 & 11.8 & 12.6 & $6.74 \%$ \\
Trade, catering, repair & 1,578 & 12.6 & 1.3 & 12.0 & 13.1 & $9.19 \%$ \\
Transport & 672 & 12.3 & 1.5 & 12.0 & 12.7 & $5.87 \%$ \\
Business services & 1,439 & 14.1 & 1.9 & 13.1 & 15.0 & $14.3 \%$ \\
Life sciences and health & 1,861 & 13.8 & 1.6 & 13.3 & 14.3 & $7.10 \%$ \\
Other services & 840 & 13.6 & 1.8 & 13.8 & 13.5 & $-1.96 \%$ \\
Government & 829 & 14.0 & 1.4 & 13.1 & 14.5 & $10.4 \%$ \\
Education & 1,108 & 16.5 & 1.1 & 16.3 & 16.5 & $0.67 \%$ \\
\hline \hline
\end{tabular}

\subsubsection{Labour supply}

The Labour Supply Panel is biannually conducted and contains data on various aspects of the labour situation of employed and unemployed individuals aged between 16 and 66 years. On average, respondents participated three times in the survey. Questions typically deal with labour mobility, education and search behaviour for (other) jobs. The panel is used to construct the variable 'years and months in formal education on the regional labour market'. Between 1990 and 2010, 56,122 individuals were asked to report their highest attained level of formal education. As discussed earlier, we will use the educational attainment of the local labour force in year $t-1$, to instrument for the educational attainment of companies' employees in year $t$. For each NUTS3 ${ }^{18}$ (in Dutch: COROP) region and for each year in our dataset, we determined the average years/months individuals have been in formal schooling. There are 40 NUTS3 regions in

18 The NUTS, the Nomenclature of Territorial Units for Statistics, is a geocode standard referencing the subdivisions of countries for statistical purposes. Depending on the size of the country, three levels of NUTS can be distinguished. Here, we use NUTS3 as a definition for the regions. 
the Netherlands, providing us 440 observations (i.e. 40 NUTS3 regions $\times 11$ years). To obtain more information on how the educational attainment of men and women in the regional labour force relates to the human capital available within companies, we created two additional variables that distinguish between the formal schooling acquired by women and men.

Table 3.4 presents summary statistics of the educational attainment for the full sample. The educational composition of the labour force is plotted on Figure 3.2 by gender and by highest level of education attained. The average years in formal schooling of the labour supply equals 13.2. Figure 3.2 shows that a rising share of individuals has obtained a professional higher education ( $b b o$ ) or a university degree during the last two decades. Also the proportion of individuals obtaining a vocational education (mbo), a general secondary education (havo) or a pre-university education degree ( $v w 0$ ) has increased over time. Moreover, the share of individuals in the labour force with primary education as the highest attained level of education or school dropouts from secondary education (vmbo) has declined.

\section{Table 3.4: Years in formal education on the regional labour market by gender}

\begin{tabular}{lccccc}
\hline \hline & $\mathrm{N}$ & Mean & Std.dev. & Min & Max \\
\hline All respondents & & & & & \\
$\quad$ Education (in years) & 440 & 13.2 & 0.7 & 11.0 & 14.9 \\
$\quad$ Education (in months) & 440 & 158.1 & 8.9 & 132.0 & 178.3 \\
Female respondents & & & & & \\
$\quad$ Education (in years) & 440 & 13.0 & 0.8 & 10.3 & 14.9 \\
$\quad$ Education (in months) & 440 & 156.4 & 9.2 & 123.0 & 178.2 \\
Male respondents & 440 & 13.3 & 0.8 & 10.9 & 15.0 \\
$\quad$ Education (in years) & 440 & 159.8 & 9.5 & 130.5 & 180.3 \\
$\quad$ Education (in months) & & & & & \\
\hline \hline
\end{tabular}

Notes: data is collapsed by NUTS3 region and year

Although the gap between men's and women's perspectives in the labour market has closed, there are still some notable gender differences. Figure 3.2 shows that between 1990 and 2010, about 27 percent of the male respondents acquired a university or professional higher education degree, compared to 22 percent of the female respondents. The largest gender differences are found for university education with completion rates of 8.2 percent for men and 4.7 percent for women. However, we observe a steep increase in the percent of women with a higher education degree, indicating that women are catching up. As from 1996, the share of women in the labour force without a secondary school-leaving certificate (i.e. school dropouts) declined from almost 45 percent to 26 percent in 2010 . 
Chapter 3

Figure 3.2: Educational composition of women and men in the labour market 1990-2010
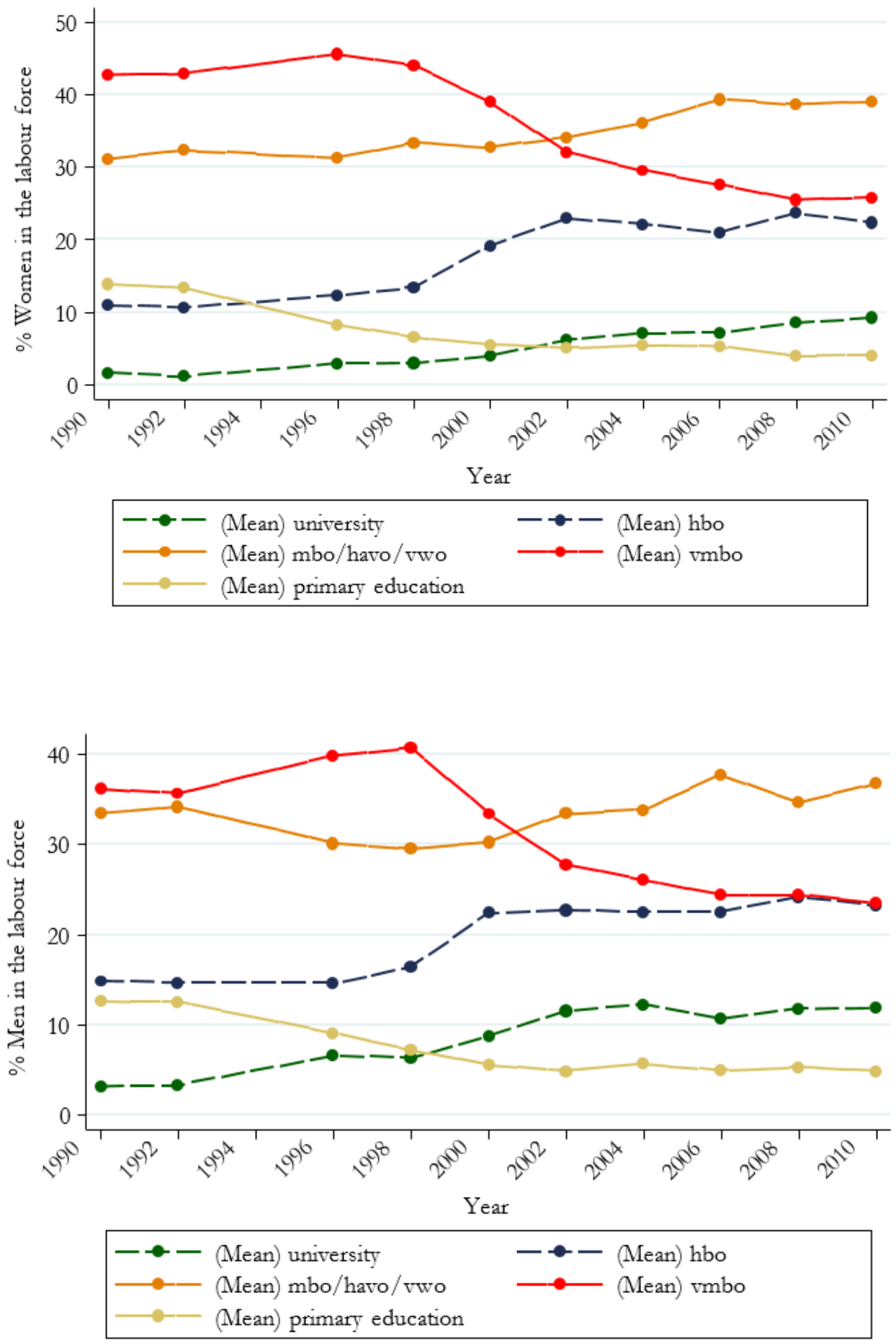


\subsubsection{Control variables}

Table 3.5 summarises a set of control variables that may affect the likelihood that companies report mismatch. We account for workforce characteristics including the average age of companies' workforce and the type of contracts employees hold. We also control for company characteristics including the size of the company, the cyclical sensitivity and whether the company has a collective bargaining agreement. Finally, we account for respondents, job function, and for companies' location sorting behaviour. To account for location sorting behaviour, we include variables that deal with the year of start-up and with whether relocation took place during the sampling period.

Table 3.5: Summary statistics of the control variables

\begin{tabular}{|c|c|c|c|c|c|}
\hline & $\overline{\mathrm{N}}$ & Mean & Std.dev. & Min & Max \\
\hline \multicolumn{6}{|l|}{ Workforce characteristics } \\
\hline Average age of employees & 11,817 & 38.561 & 6.04 & 17.5 & 63.2 \\
\hline $\begin{array}{l}\text { Employees with temporary } \\
\text { contracts }(1=\text { yes, } 0=\text { no })\end{array}$ & 11,817 & 0.3866 & 0.4870 & 0 & 1 \\
\hline \multicolumn{6}{|l|}{ Company characteristics } \\
\hline \multicolumn{6}{|l|}{ Company size } \\
\hline 0 - 19 employees & 11,817 & 0.3790 & 0.485 & 0 & 1 \\
\hline 20 - 49 employees & 11,817 & 0.1970 & 0.398 & 0 & 1 \\
\hline 50 - 99 employees & 11,817 & 0.1380 & 0.345 & 0 & 1 \\
\hline 100 - 199 employees & 11,817 & 0.1400 & 0.347 & 0 & 1 \\
\hline$>200$ employees & 11,817 & 0.1460 & 0.353 & 0 & 1 \\
\hline \multicolumn{6}{|l|}{ Status of respondent } \\
\hline $\begin{array}{l}\text { Respondent is HR manager } \\
(1=\text { yes, } 0=\text { no })\end{array}$ & 11,817 & 0.1890 & 0.3920 & 0 & 1 \\
\hline $\begin{array}{l}\text { Respondent is HR officer } \\
(1=\text { yes, } 0=\text { no })\end{array}$ & 11,817 & 0.0690 & 0.2540 & 0 & 1 \\
\hline \multicolumn{6}{|l|}{ Cyclical sensitivity } \\
\hline Strong & 11,817 & 0.2600 & 0.4390 & 0 & 1 \\
\hline Somewhat & 11,817 & 0.3920 & 0.4880 & 0 & 1 \\
\hline Barely & 11,817 & 0.3480 & 0.4760 & 0 & 1 \\
\hline $\begin{array}{l}\text { Collective bargaining agreement } \\
(1=\text { yes, } 0=\text { no })\end{array}$ & 11,665 & 0.8494 & 0.3577 & 0 & 1 \\
\hline \multicolumn{6}{|l|}{ Location sorting } \\
\hline $\begin{array}{l}\text { Company switched region } \\
(1=\text { ves }, 0=\text { no })\end{array}$ & 11,817 & 0.0143 & 0.1187 & 0 & 1 \\
\hline Age company & 10,829 & 30.278 & 29.508 & 0 & 600 \\
\hline
\end{tabular}




\subsection{Empirical estimation}

We estimate the effect of the human capital $H_{c t}$ available to company $c$ in year $t$ on employers' perception on the match $m_{c t}$ between skill demand and skill supply within the company. We then may write:

$$
m_{c t}=\alpha_{0}+\alpha_{1} H_{c t}+\alpha_{2} X_{c t}+\eta_{r}+\eta_{s}+\varepsilon_{c t}
$$

where $m_{c t}$ is equal to 1 if company $c \in\{1,2, \ldots, \mathrm{N}\}$ reports mismatch in year $t$, and 0 otherwise; $X_{c t}$ constitutes a vector of company characteristics; $\eta_{r}$ and $\eta_{s}$ represent, respectively, region and sector fixed effects and $\varepsilon_{c t}$ is the error term.

First, Equation (1) will be estimated by using a pooled ordinary least squares (OLS) regression without control variables (model a). Subsequently, five extended regressions will be estimated by adding the available control variables in the following order: (b) average age of employees, (c) whether the company uses temporary contracts, (d) the size of the company and the job function of the respondent, (e) cyclical sensitivity and (f) whether the company is subject to a collective

bargaining agreement, whether the company changed location during the sample period, and, the age of the company. The region and sector fixed effects specification will be used across all models to control for region- and sector-specific trends. All models cluster the standard errors at the level of the unique identification number of the company. Robust standard errors, controlling for heteroscedasticity, are presented.

Using pooled OLS estimation might yield biased estimates due to endogeneity. This study addresses this endogeneity problem by instrumenting the educational composition of companies' workforce with the average schooling level of the regional labour force in a two-stage estimation approach. First, we estimate a regression using the endogenous regressor as the dependent variable, and the instrument as the independent variable. The first-stage regression can be written as follows:

$$
H_{c t}=\beta_{0}+\beta_{3} H L F_{r t-1}+\beta_{4} H L M_{r t-1}+\beta_{2} X_{c t}+\eta_{r}+\eta_{s}+v_{c t}
$$

From Equation (2), fitted values $\widehat{H}_{c t}$ can be computed and plugged into the second-stage regression (see Equation (3)). While $H L F_{r t-1}$ denotes the average month in formal schooling of female workers, $H L M_{r t-1}$ represents the months years in formal schooling of male workers, both measured at the level of the regional labour market $r$. The secondstage regression estimates the effect of a one-month increase in companies' human capital stock that can only be explained by increasing the levels of formal education of 
men and/or women on the regional labour market, on mismatch. This effect is captured by the parameter $\alpha_{1}$ in Equation (3).

$$
m_{c t}=\alpha_{0}+\alpha_{1} \widehat{H}_{c t}+\alpha_{2} X_{c t}+\eta_{r}+\eta_{s}+\varepsilon_{c t}
$$

\subsection{Results}

\subsubsection{OLS results}

Table 3.6 presents the results of the pooled OLS regression as defined in Equation (1). A one-month increase in the average months of schooling within the company is related to a 0.1 percentage points decrease in the likelihood that firms report mismatch (model 1a). The estimates with respect to companies' human capital stock $\left(H_{c t}\right)$ are significantly negative in model (a) until (e). In model (e), the coefficient of interest approach zero and in model ( $\mathrm{f}$ ) the coefficient becomes insignificant.

\section{Table 3.6: Results of the pooled OLS estimates (Equation 1)}

\begin{tabular}{lcccccc}
\hline \hline $\mathrm{y}=$ mismatch $m_{c t}$ & model(1a) & model(1b) & model(1c) & model(1d) & model(1e) & model(1f) \\
\hline HC within company $H_{c t}$ & $-0.0005^{* *}$ & $-0.0005^{* *}$ & $-0.0008^{* * *}$ & $-0.0004^{* *}$ & $-0.0004^{* *}$ & -0.0004 \\
& $(0.000)$ & $(0.000)$ & $(0.000)$ & $(0.000)$ & $(0.000)$ & $(0.000)$ \\
Control variables $(1)$ & No & Yes & Yes & Yes & Yes & Yes \\
\hline Number of clusters & 7,451 & 7,451 & 7,451 & 7,451 & 7,451 & 6,760 \\
Number of obs & 11,817 & 11,817 & 11,817 & 11,817 & 11,817 & 10,686 \\
Adj. R-squared & 0.023 & 0.023 & 0.032 & 0.065 & 0.067 & 0.069 \\
\hline \hline
\end{tabular}

Notes: Models b-f add control variables to the basic specification (model a): average age employees (included in model b), labour flexibility (included in models c-f), company size and respondent's job function (included in models $\mathrm{d}-\mathrm{f}$ ), cyclical sensitivity (included in models e-f), location sorting and collective bargaining agreement (included in model f). All models account for region- and sector fixed effects. Standard errors clustered at the level of the company unit are in parentheses. Asterisks indicate significance levels: ${ }^{*} \mathrm{p}<0.10,{ }^{* *} \mathrm{p}<0.05,{ }^{* * *} \mathrm{p}<0.01$.

\subsubsection{Instrumental variables results}

\section{First-stage estimates}

Table 3.7 presents the first-stage regression results as specified in Equation (2). The human capital on the regional labour market has a positive relationship with the human capital within companies across all models. A one-month increase in the average months of education attained among female workers in the regional labour force in $t-1$ is associated with a 0.222 months increase in the average months of schooling within companies in year $t$. For men, the estimated relation equals 0.154 months. The coefficient signs remain positive and significant after the inclusion of control variables. The educational attainment of women in the regional labour force appears to be a better 
predictor for the educational composition of companies' workforce. Working females commute less and are more likely to select a job location closer to their place of residence as they tend to put a higher value on time spent commuting due to household commitments (Turner \& Niemeier, 1997).

In Table 3.7 also presents the under-identification test, the weak identification test, and the over-identification test statistics, all dealing with the validity of the instrumental variables estimation. It should be noted that the over-identification test cannot be performed when having only one instrument (Hayashi, 2000). Notwithstanding the fact that having two gender-specific instruments yield a Hansen's J Statistics, caution with interpretation of these statistics are advised, as we still do not have two totally distinct instruments at hand.

First, the under-identification test indicates whether there are evenly or more 'relevant' instruments than endogenous regressors. For the basic model without control variables, the Kleibergen-Paap rank LM statistic is equal to 152.707 and significant at the 1 percent level. After the inclusion of all control variables, the Kleibergen-Paap statistic decreases to 64.566 and remains significant at the 1 percent level. Hence, we reject the null hypothesis of under-identification.

The weak identification test indicates whether the instruments (gender-specific level of formal schooling on the regional labour market) identifies the endogenous regressor well (level of formal schooling within the company). A weak instrument only explains little to no variance of the endogenous regressor and can be considered a poor predictor of the endogenous regressor (Bound et al., 1995). For estimating Equation (2) without control variables, the Cragg-Donald Wald F-statistics indicates a value of 136.176. Compared to the Stock Yogo threshold of 19.93, the F-statistic is higher than the indicated critical value for a maximum bias level of 10 percent. Also in the extended model including all control variables, the F-statistic remains above the Stock Yogo threshold (54.967>19.93). As such, we do not deal with problems of weak identification.

To conclude, the over-identification test indicates whether the instrument is 'truly' exogenous. The Hansen $J$ statistic for the models without control variables is equal to 0.318 and not significant ( $\mathrm{p}$-value of 0.5726 ). Adding control variables does not change statistical inference. The Hansen J statistic yields 1.093 and is insignificant ( $p$-value of 0.2959). Therefore, we accept the null hypothesis of instrument validity. 
Table 3.7: Results of the 1st-stage estimates (Equation 2)

\begin{tabular}{|c|c|c|c|c|c|c|}
\hline $\mathrm{y}=\mathrm{HC}$ within company $H_{c t}$ & $\operatorname{model}(2 \mathrm{a})$ & $\operatorname{model}(2 \mathrm{~b})$ & $\operatorname{model}(2 \mathrm{c})$ & $\operatorname{model}(2 \mathrm{~d})$ & $\operatorname{model}(2 \mathrm{e})$ & $\operatorname{model}(2 \mathrm{f})$ \\
\hline HC on labour market & $0.222^{* * *}$ & $0.200^{* * *}$ & $0.181^{* * *}$ & $0.147^{* * *}$ & $0.147^{* * *}$ & $0.124^{* * *}$ \\
\hline Females $H L F_{r t-1}$ & $(0.051)$ & $(0.052)$ & $(0.051)$ & $(0.051)$ & $(0.051)$ & $(0.052)$ \\
\hline HC on labour market & $0.154^{* * *}$ & $0.149^{* * *}$ & $0.143^{* * *}$ & $0.143^{* * *}$ & $0.143^{* * *}$ & $0.147^{* * *}$ \\
\hline Males $H L M_{r t-1}$ & $(0.021)$ & $(0.052)$ & $(0.051)$ & $(0.051)$ & $(0.051)$ & $(0.051)$ \\
\hline Controls variables(1) & No & Yes & Yes & Yes & Yes & Yes \\
\hline \multicolumn{7}{|l|}{ Under-identification } \\
\hline Kleibergen-Paap rank & 152.707 & 118.504 & 102.254 & 79.039 & 78.643 & 64.566 \\
\hline LM statistic & $(\mathrm{p}<0.01)$ & $(\mathrm{p}<0.01)$ & $(\mathrm{p}<0.01)$ & $(\mathrm{p}<0.01)$ & $(\mathrm{p}<0.01)$ & $(\mathrm{p}<0.01)$ \\
\hline \multicolumn{7}{|l|}{$\underline{\text { Weak identification }}$} \\
\hline $\begin{array}{l}\text { Cragg-Donald Wald F } \\
\text { statistic }\end{array}$ & $136.176>$ & $109.911>$ & $94.376>$ & 69.027> & $68.853>$ & $54.967>$ \\
\hline Stock Yogo threshold & 19.93 & 19.93 & 19.93 & 19.93 & 19.93 & 19.93 \\
\hline Bias level & $10 \%$ & $10 \%$ & $10 \%$ & $10 \%$ & $10 \%$ & $10 \%$ \\
\hline \multicolumn{7}{|l|}{$\underline{\text { Over-identification }}$} \\
\hline \multirow[t]{2}{*}{ Hansen's J statistic } & 0.318 & 0.491 & 0.649 & 0.556 & 0.643 & 1.093 \\
\hline & $(p=0.5726)$ & $(p=0.4835)$ & $(p=0.4204)$ & $(p=0.4559)$ & $(p=0.4228)$ & $(p=0.2959)$ \\
\hline Number of clusters & 7,451 & 7,451 & 7,451 & 7,451 & 7,451 & 6,760 \\
\hline Number of obs & 11,817 & 11,817 & 11,817 & 11,817 & 11,817 & 10,868 \\
\hline Adj. $R^{2}$ & 0.446 & 0.447 & 0.452 & 0.458 & 0.458 & 0.467 \\
\hline
\end{tabular}

Notes: Models b-f add control variables to the basic specification (model a): average age employees (included in model b), labour flexibility (included in models c-f), company size and respondent's job function (included in models $\mathrm{d}-\mathrm{f}$ ), cyclical sensitivity (included in models e-f), location sorting and collective bargaining agreement (included in model f). All models account for region- and sector fixed effects. Standard errors clustered at the level of the company unit are in parentheses. Asterisks indicate significance levels: ${ }^{*} \mathrm{p}<0.10,{ }^{* *} \mathrm{p}<0.05,{ }^{* * *} \mathrm{p}<0.01$.

\section{Second-stage estimates}

The second-stage regression results of the analyses are presented in Table 3.8. Model (3f) shows that a one-month increase in employees' formal schooling reduces the probability that companies report mismatch with 3 percentage points (or -0.064 of one standard deviation). The coefficient of interest slightly increases in magnitude as we move from the basic model without control variables to model (3b). Model (3b) demonstrates that companies with older employees are more likely to report mismatch, suggesting that older workers suffer from skill obsolescence which is not being offset by their job experience (De Grip \& Van Loo, 2002). Also companies using temporary contracts are less likely to report mismatch as such contracts allow companies to more easily lay off workers with inadequate skills. With respect to the company size, large sized companies are more likely to report mismatch in comparison to the smallest companies. Model (3d) also includes two variables indicating whether the respondent is either an HR manager or 
Table 3.8: Results of the 2nd-stage estimates (Equation 3)

\begin{tabular}{|c|c|c|c|c|c|c|}
\hline \multirow{2}{*}{$\frac{\mathrm{y}=\text { mismatch } m_{c t}}{\text { HC within company } \widehat{H}_{c t}}$} & \multicolumn{6}{|c|}{$\operatorname{model}(3 \mathrm{a}) \operatorname{model}(3 \mathrm{~b}) \operatorname{model}(3 \mathrm{c}) \operatorname{model}(3 \mathrm{~d}) \operatorname{model}(3 \mathrm{e}) \operatorname{model}(3 \mathrm{f})$} \\
\hline & $\begin{array}{c}-0.024^{* * *} \\
(0.003)\end{array}$ & $\begin{array}{c}-0.029^{* * *} \\
(0.003)\end{array}$ & $\begin{array}{c}-0.033^{* * *} \\
(0.004)\end{array}$ & $\begin{array}{c}-0.027^{* * *} \\
(0.004)\end{array}$ & $\begin{array}{c}-0.027^{* * *} \\
(0.004)\end{array}$ & $\begin{array}{c}-0.030^{* * *} \\
(0.005)\end{array}$ \\
\hline $\begin{array}{l}\text { [HC within company } \widehat{H}_{c t} \text {, } \\
\text { mismatch standardized] }\end{array}$ & $\begin{array}{c}{[-0.052]^{* * *}} \\
(0.006)\end{array}$ & $\begin{array}{c}{[-0.061]^{* * *}} \\
(0.007)\end{array}$ & $\begin{array}{c}{[-0.070]^{* *-}} \\
(0.008)\end{array}$ & $\begin{array}{c}{[-0.058]^{* * *}} \\
(0.008)\end{array}$ & $\begin{array}{c}{[-0.057]^{* *-}} \\
(0.008)\end{array}$ & $\begin{array}{r}{[-0.064]^{* * *}} \\
(0.010)\end{array}$ \\
\hline \multicolumn{7}{|l|}{ Controls } \\
\hline Average age employees & & $\begin{array}{l}0.007^{* * *} \\
(0.002)\end{array}$ & $\begin{array}{l}0.009^{* * *} \\
(0.002)\end{array}$ & $\begin{array}{l}0.007^{* * *} \\
(0.002)\end{array}$ & $\begin{array}{l}0.007^{* * *} \\
(0.002)\end{array}$ & $\begin{array}{l}0.008^{* * *} \\
(0.002)\end{array}$ \\
\hline $\begin{array}{l}\text { Employees with temporary } \\
\text { contracts }(1=\text { yes, } 0=\text { no })\end{array}$ & & & $\begin{array}{c}-0.217^{* * *} \\
(0.022)\end{array}$ & $\begin{array}{c}-0.143^{* * *} \\
(0.023)\end{array}$ & $\begin{array}{c}-0.142^{* * *} \\
(0.023)\end{array}$ & $\begin{array}{c}-0.150^{* * *} \\
(0.026)\end{array}$ \\
\hline \multicolumn{7}{|l|}{ Company size } \\
\hline 0-19 employees & & & & $\begin{array}{l}(.) \\
(.)\end{array}$ & $\begin{array}{l}(.) \\
(.)\end{array}$ & $\begin{array}{l}(.) \\
(.)\end{array}$ \\
\hline 20-49 employees & & & & $\begin{array}{l}0.076^{* * *} \\
(0.021)\end{array}$ & $\begin{array}{l}0.075^{* * *} \\
(0.021)\end{array}$ & $\begin{array}{l}0.075^{* * *} \\
(0.023)\end{array}$ \\
\hline 50-99 employees & & & & $\begin{array}{l}0.035 \\
(0.030)\end{array}$ & $\begin{array}{c}0.034 \\
(0.030)\end{array}$ & $\begin{array}{c}0.028 \\
(0.033)\end{array}$ \\
\hline 100-199 employees & & & & $\begin{array}{l}0.097^{* * *} \\
(0.029)\end{array}$ & $\begin{array}{l}0.096^{* * *} \\
(0.029)\end{array}$ & $\begin{array}{l}0.121^{* * *} \\
(0.031)\end{array}$ \\
\hline$>200$ employees & & & & $\begin{array}{l}0.081^{* *} \\
(0.038)\end{array}$ & $\begin{array}{l}0.080^{* *} \\
(0.037)\end{array}$ & $\begin{array}{l}0.083^{* *} \\
(0.041)\end{array}$ \\
\hline $\begin{array}{l}\text { Respondent is HR manager } \\
\quad(1=\text { yes, } 0=\text { no })\end{array}$ & & & & $\begin{array}{l}0.149^{* * *} \\
(0.029)\end{array}$ & $\begin{array}{l}0.147^{* * *} \\
(0.029)\end{array}$ & $\begin{array}{l}0.133^{* * *} \\
(0.031)\end{array}$ \\
\hline $\begin{array}{l}\text { Respondent is HR officer } \\
\quad(1=\text { yes, } 0=\text { no })\end{array}$ & & & & $\begin{array}{l}0.118^{* * *} \\
(0.036)\end{array}$ & $\begin{array}{l}0.115^{* * *} \\
(0.036)\end{array}$ & $\begin{array}{l}0.101^{* *} \\
(0.040)\end{array}$ \\
\hline \multicolumn{7}{|l|}{ Cyclical sensitivity } \\
\hline Strong & & & & & $\begin{array}{l}(.) \\
(.)\end{array}$ & $\begin{array}{l}(.) \\
(.)\end{array}$ \\
\hline Some & & & & & $\begin{array}{l}-0.019 \\
(0.018)\end{array}$ & $\begin{array}{l}-0.024 \\
(0.019)\end{array}$ \\
\hline Hardly any & & & & & $\begin{array}{l}-0.046^{* *} \\
(0.020)\end{array}$ & $\begin{array}{l}-0.046^{* *} \\
(0.022)\end{array}$ \\
\hline $\begin{array}{l}\text { Collective bargaining } \\
\text { agreement }(1=\text { yes, } 0=\text { no })\end{array}$ & & & & & & $\begin{array}{c}-0.231^{* * *} \\
(0.043)\end{array}$ \\
\hline $\begin{array}{l}\text { Company switched region } \\
\qquad(1=\text { yes, } 0=\text { no })\end{array}$ & & & & & & $\begin{array}{l}0.280^{* * *} \\
(0.092)\end{array}$ \\
\hline Age company & & & & & & $\begin{array}{c}-0.001^{* * *} \\
(0.000) \\
\end{array}$ \\
\hline Number of clusters & 7,451 & 7,451 & 7,451 & 7,451 & 7,451 & 6,767 \\
\hline Number of obs & 11,817 & 11,817 & 11,817 & 11,817 & 11,817 & 10,686 \\
\hline Adj. $R^{2}$ & 0.047 & 0.049 & 0.061 & 0.083 & 0.084 & 0.082 \\
\hline
\end{tabular}

Notes: Models b-f add control variables to the basic specification (model a): average age employees (included in model b), labour flexibility (included in models c-f), company size and respondent's job function (included in models $\mathrm{d}-\mathrm{f}$ ), cyclical sensitivity (included in models e-f), location sorting and collective bargaining agreement (included in model f). All models account for region- and sector fixed effects. Standard errors clustered at the level of the company unit are in parentheses. Asterisks indicate significance levels: $* \mathrm{p}<0.10,{ }^{* *} \mathrm{p}<0.05,{ }^{* * *} \mathrm{p}<0.01$. 
an HR officer. As HR managers or HR officers are considered responsible for bringing about a proper worker-company match, their response on the mismatch question may be biased. However, the inclusion of these variables leaves the sign and significance level of the coefficient of interest unchanged. Model (3e) shows that compared to companies that are strongly sensitive to cyclical changes, companies that are hardly sensitive to changes in the economy are less likely to report mismatch. Hiring people with the appropriate skills becomes more difficult in times of economic growth, as the competition for labour becomes fiercer during such periods (Nickell, 1978). This especially holds for companies that are more sensitive to cyclical changes. Finally, model (3f) shows that our coefficient of interest remains negative and significant when controlling for whether companies are subject to a collective bargaining agreement and for companies' location sorting behaviour. Given that the share of employers reporting mismatch is rather dispersed across sectors (see Table 3.2), the results are most strongly driven by those sectors that have witnessed the greatest decline in the share of companies experiencing mismatch.

The pooled two-stage least squares estimator assumes that the effect of workers' educational attainment on mismatch is the same within each company. This assumption is only appropriate if company effects do not vary once we account for company and workforce characteristics. If company effects are related to the educational composition of the company's workforce, variations in the effect of workers' formal schooling on mismatch need to be modelled to obtain unbiased estimates. We re-estimated Equations (2) and (3) using the generalised two-stage least squares random-effects estimator. ${ }^{19}$ The second stage results can be found in Appendix 3.1 (Table 3.9) and are comparable to the results of the pooled regression models. We conclude that if company specific effects exist, they are not systematic but distributed randomly across firms. Hence, the results of the pooled regression models can be considered robust.

\subsection{Conclusion and discussion}

Using a rich and unique dataset for the Netherlands, this study explored whether the increased supply of tertiary graduates has improved the match between skill supply and job requirements within companies. Whereas prior studies focused on employees' perspective, we derived our measurement of mismatch from the perspective of employers. While almost 50 percent of the Dutch employers reported mismatch in 1991, in 2011, this was only 25 percent.

19 In line with Clark and Linzer (2015), we prefer the random-effects specification over the fixedeffects specification as we have many units in our data (over 7000 unique companies), but few observations of each company (on average, each company appears twice in the data). 
The first-stage estimates demonstrate that a one-month increase in formal schooling acquired by the regional labour force increases the educational attainment of companies' staff with almost 0.3 months. The second-stage results indicate that a one-month increase in companies' workforce average schooling level decreases companies' probability of experiencing mismatch with 3 percentage points. Our findings, therefore, show that firms have benefitted from the increasing supply of skilled labour.

Given that the Dutch college premium has continued to rise since the early nineties (Van den Berge \& Ter Weel, 2015; Hartog \& Gerritsen, 2016; Jacobs \& Webbink, 2006; Leuven \& Oosterbeek, 2000), our results could indicate that the supply of tertiary education graduates has responded positively to an increasing demand for skilled labour. In the case that the demand for skilled labour has indeed outpaced the supply of college graduates as the development of the college premium proposes, a declining mismatch trend would suggest that the value of an additional year of schooling has increased over time.

However, the findings of our study could also mask a situation in which the presence of over-educated workers at the workplace has intensified over the past decades. Despite the increasing college premium, previous literature indicates that the increased number of high-skilled jobs has not been able to absorb the rising supply of skilled labour (Hartog, 2000; Muysken, Kiiver \& Hoppe, 2003). As a consequence, job seekers can be forced to accept jobs below their level of education, at least in knowledge-based sectors. Provided that prior studies have illustrated that the presence of over-qualified employees can affect firm output adversely as well as beneficially (Büchel 2002; Kampelmann \& Rycx 2012; Tsang 1987), it remains unclear whether employers are willing or hesitant to hire overeducated workers. Hence, further research is needed to point out whether our findings merely reflect a rising incidence of over-education in the Dutch labour market.

While this chapter focussed on the match between job requirements and the increased supply of tertiary graduates, the skills supplied by college graduates and therefore also the labour market prospects are heterogeneous across college majors (Machin \& McNally 2007). Hence, linking mismatch within companies to individuals' choice to enrol in a specific field-of-study provides interesting scope for future research. Future research could also explore how the observed mismatch trend relates to on-the-job training and the ability of school curricula to adjust to changing skill requirements. 
Appendix 3.1: Robustness checks

Table 3.9: Results of the second-stage estimates using a random effects specification

\begin{tabular}{lcccccc}
\hline \hline $\mathrm{y}=$ mismatch $m_{c t}$ & model3(a) & model3(b) & model3 (c) & model3(d) & model3 (e) & model3(f) \\
\hline HC within company $\widehat{H}_{c t}$ & $-0.019^{* * *}$ & $-0.025^{* * *}$ & $-0.027^{* * *}$ & $-0.023^{* * *}$ & $-0.023^{* * *}$ & $-0.027^{* * *}$ \\
& $(0.002)$ & $(0.003)$ & $(0.003)$ & $(0.003)$ & $(0.003)$ & $(0.004)$ \\
Controls $^{\mathrm{a}}$ & No & Yes & Yes & Yes & Yes & Yes \\
$\begin{array}{l}\text { Dummies for COROP } \\
\text { region and sector }\end{array}$ & Yes & Yes & Yes & Yes & Yes & Yes \\
\hline Number of obs & 11,817 & 11,817 & 11,817 & 11,817 & 11,817 & 10,868 \\
Number of groups & 7,451 & 7,451 & 7,451 & 7,451 & 7,451 & 6,760 \\
$R^{2}$ within & 0.001 & 0.001 & 0.000 & 0.000 & 0.000 & 0.000 \\
$R^{2}$ between & 0.005 & 0.005 & 0.006 & 0.014 & 0.014 & 0.011 \\
$R^{2}$ overall & 0.004 & 0.003 & 0.004 & 0.010 & 0.011 & 0.008 \\
sigma u & .404 & .510 & .584 & .511 & .509 & 0.565 \\
sigma e & .405 & .409 & .410 & .413 & .412 & 0.428 \\
Rho & .499 & .608 & .670 & .605 & .605 & 0.636 \\
\hline \hline
\end{tabular}

Notes: Models b-f add control variables to the basic specification (model a): average age employees (included in model b), labour flexibility (included in models c-f), company size and respondent's job function (included in models $\mathrm{d}-\mathrm{f}$ ), cyclical sensitivity (included in models e-f), location sorting and collective bargaining agreement (included in model f). All models account for region- and sector fixed effects. Standard errors clustered at the level of the company unit are in parentheses. Asterisks indicate significance levels: ${ }^{*} \mathrm{p}<0.10,{ }^{* *} \mathrm{p}<0.05,{ }^{* * *} \mathrm{p}<0.01$. 



\section{Part 2}

Preventing Mismatch Between Human Capital and

Labour Demand 



\section{Chapter 4}

\section{The Effect of a Five-Day Intervention on STEM Enrolment in Vocational Education and Training - Evidence from the Netherlands ${ }^{20,21,22}$}

20 This study is based on: Somers, M. A., \& Cabus, S. J. (2019). The effect of a five-day intervention on STEM enrolment in vocational education and training - Evidence from the Netherlands. House of Skills Working Paper Series. ISBN 978-90-830241-4-1.

21 This study benefitted from discussions with participants of the Third LEER Conference on Education Economics, participants of the XXVI Meeting of the Economics of Education Association (AEDE), participants of the Second Centre for Vocational Education Research Conference (CVER) conference, participants of Second Workshop on Empirical Research in Economics of Education, participants of the 15 $5^{\text {th }}$ Belgian Day for Labour Economists (BDLE), participants of Ninth International Workshop on Applied Economics of Education (IWAEE), participants of the 32nd European Society for Population Economics Conference (ESPE), and participants of the 33rd Congress of the European Economic Association (EEA).

22 This study was financially supported by Sectoral Plan 'Werk maken van Talent' and the Amsterdam Economic Board. The partners of Sectoral Plan 'Werk maken van Talent' and the Amsterdam Economic Boards were not involved in the preparation of this chapter. 
Chapter 4

\begin{abstract}
While many job opportunities are available for Science, Technology, Engineering and Mathematics (STEM) graduates, STEM programmes offered in vocational education suffer from low student enrolment. This study examines the effectiveness of a five-day programme conducted in the Amsterdam Metropolitan Area in the schoolyear 2014-15. The intervention aimed at encouraging students from preparatory vocational education to choose STEM education in upper-secondary vocational education and training. The difference-in-differences analysis indicates that the intervention did not affect native Dutch male students' likelihood of enrolling into STEM education. For male students with an immigrant background, the intervention increased the probability of STEMenrolment by 0.6 percentage points.
\end{abstract}




\subsection{Introduction}

The demand for graduates in Science, Technology, Engineering and Mathematics (STEM) has increased in most European Union countries, including the Netherlands, and is expected to grow further in the coming years (BusinessEurope, 2011; Cedefop, 2014a; Cedefop, 2014b; European Commission, 2014; ROA, 2017a). This does not only hold for STEM graduates from higher education, but also for graduates from upper-secondary vocational education and training (VET). Despite the fact that STEM is often associated with the image of highly educated scientists in white lab coats, VET graduates traditionally form an important supply source for STEM-related skills. In fact, 48 percent of STEM-related occupations require medium level qualifications that are typically acquired through upper-secondary VET (Cedefop, 2014b). STEM education in VET prepares students for a wide range of occupations including construction workers, electricians, mechanical technicians, maintenance and repair workers, and sheet metal workers. While the supply of university graduates with STEM-credentials on the EU-28 labour market slightly increased from 22 percent in 2007 to 23 percent in 2012, the share of VET graduates with a STEM degree decreased from 32 percent in 2006 to 30 percent in 2011 (Cedefop, 2014a; Cedefop, 2014b). Likewise, in the Netherlands, the share of VET graduates with a STEM degree declined from 31 percent in 2005 to 26 percent in the schoolyear 2013-14 (Monitor Techniekpact, 2019). ${ }^{23}$

This latter result can go hand in hand with non-negligible consequences in light of the increasing demand for workers with a STEM degree from VET and the destruction of jobs that are typically held by VET graduates (Autor \& Dorn, 2013; Autor et al., 2003; Van den Berge \& ter Weel, 2015; Goos et al., 2014; Michaels, Natraj \& Van Reenen, 2014). Poor demand in the labour market for a specific field-of-study can force graduates to accept a job that is unrelated to the attended field- and/or level of education (Borghans \& de Grip, 2000; Wolbers, 2003). Chapter 2 already highlighted that education-job mismatches can result in an underutilization of skills, wage penalties, job dissatisfaction, and as shown in Chapter 5, regret of the chosen field-of-study.

This study investigates the effectiveness of a newly designed five-day programme for 15year-old students in preparatory vocational education (pre-VET or in Dutch: vmbo) in the Amsterdam Metropolitan Area, who are about to choose their field-of-study in VET. The main target of the programme is to encourage students from pre-VET to choose for a STEM programme. There is a high demand for STEM graduates on the regional labour market of the Amsterdam Metropolitan Area (www.s-bb.nl). As such, the five-day

${ }^{23}$ The statistics can be found on https://www.techniekpactmonitor.nl/mbo. 
intervention targets to improve the connection between education and the labour market in the long run. ${ }^{24}$

Students might make sub-optimal study choices due to uncertainty regarding their preferences, ability, as well as labour market outcomes (Altonji, Blom \& Meghir, 2012; Betts, 1996; Wiswall \& Zafar, 2015a). The five-day programme provides students the opportunity to acquire hands-on-experience with a variety of STEM occupations. Students carry out occupation-related assignments that allow them to learn about the match between the content of occupations and their abilities and preferences (Altonji et al., 2012; Wiswall \& Zafar, 2015a). During the five-day intervention, students are also informed about the labour market demand for graduates from different STEM programmes. This might affect students' choice behaviour as they tend to update their beliefs about their labour market outcomes when confronted with information on it (Hastings, Neilson \& Zimmerman, 2015; Jensen, 2010; McGuigan, McNally \& Wyness, 2016; Oreopoulos \& Dunn 2013; Wiswall \& Zafar, 2015a; Woods \& O’Leary, 2006; Zafar, 2011).

There are at least four contributions of this study to the literature. Numerous studies evaluate the effectiveness of interventions that aim to increase the enrolment of middleand high school students in STEM education and careers (e.g. Bamberger, 2014; Constan \& Spicer, 2015; Dawes, Horan \& Hackett, 2000; Gibson \& Chase, 2002; Welch, 2010; Wyss, Heulskamp \& Siebert, 2012). Interventions encompass company visits, summer camps, after school programmes or altered curricula. The majority of these studies explore the effect of interventions on short-term outcomes including students' interest in STEM careers, attitude towards STEM careers, technical self-efficacy, and achievement in STEM courses. In contrast to earlier research, this study examines the effect of a five-day study choice programme on actual enrolments rates into STEM education.

Second, most of the evaluated STEM interventions were targeted at students in the United States (Constan \& Spicer, 2015; Dawes et al., 2000; Gibson \& Chase, 2002; Greenes et al., 2011; Hiller \& Kitsantas, 2014; Jayaratne, Thomas \& Trautmann, 2003; Nugent et al., 2010; Welch, 2010; Wyss et al., 2012). The American education system is characterized by a weak tracking system and, consequently, treatment groups can be rather heterogeneous (Bol \& Van de Werfhorst, 2016). This matters as students with higher cognitive abilities tend to form more realistic expectations of their labour market

\footnotetext{
${ }^{24}$ A second aim of the intervention was to improve the match between a specific study programme within the STEM sector in VET and students who were already interested in enrolling into STEM education. Thereby, the intervention could potentially reduce the likelihood that treated students drop out in the first year in VET. Due to data restrictions, we only examine the effectiveness of the intervention in terms of enrolment into STEM.
} 
outcomes which determines, in turn, the quality of schooling choices (Borghans \& Golsteyn, 2005). For the evaluation of the intervention at hand, we benefit from a homogeneous group of treated students. The Dutch education system is characterized by the selection of students into differing-ability tracks at an early age (i.e. at age 12). Students in pre-VET make their schooling choices earlier than students in the higher tracks (16 vs. 17 or 18). Younger students, as well as students who are less academically oriented, might need different interventions in order to make an adequate study choice than older academically oriented students.

The third contribution of our study concerns our evaluation methodology. Previous studies often did not account for differences in the treatment and control group in the absence of random assignment to the treatment (e.g. Bamberger, 2014; Greenes et al., 2011; Hiller \& Kitsantas, 2014; Kim \& Chae, 2016; Welch, 2010). For example, Greenes et al. (2011) applied a matching technique, but on a sample consisting of students who decided not to participate in the intervention. We analyse the effect of this five-day intervention on enrolment rates into STEM using a difference-in-differences framework. This approach is supported by having rich and complete panel data on the educational career of each student in the Netherlands.

Finally, our analyses will be performed separately for native Dutch students and students with an immigrant background. The share of students who are enrolled into STEM education in VET in the Netherlands is substantially lower for students with an immigrant background than for native students (De Koning, Gelderblom \& Gravesteijn, 2010). An important explanation for this underrepresentation is that STEM occupations suffer from a negative image among students with an immigrant background (Kuijpers and Meijers, 2009; De Koning et al., 2010). Moreover, students with an immigrant background tend to be less confident about their ability to successfully complete a STEM programme and are less well-informed about the labour market perspectives of different educational pathways (De Koning et al., 2010; MacPhee, Farro \& Canetto, 2013). As such, students' beliefs regarding their preference, ability, and labour market outcomes is likely to be more biased for immigrant background students. Consequently, the potential of the intervention for updating students' beliefs about STEM might have been larger for immigrant background students than for native students.

This chapter proceeds as follows. The next section provides a description of the intervention. This chapter then presents the identification strategy and provides a description of the data. This is followed by the results and a discussion on the robustness of these results. This chapter ends with a conclusion and discussion. 


\subsection{Course of the intervention}

The five-day study choice programme carries the official label 'professional orientation and on-the-job assessment' (Dutch: Beroepsoriëntatie \& Praktijkassessment). The programme was part of a bigger project called 'Make talent Work' (Dutch: Werk maken van Talent) that consisted of 10 different intervention programmes in the Amsterdam Metropolitan Area. The 'professional orientation and on-the-job assessment' was one out of 10 interventions. The project has been funded for two years between 2015-2017 by different parties including the Ministry of Social Affairs and Employment, regional business and educational institutions. The project's long-run aims were to improve the connection between skill supply and skill demand in the labour market and to prevent skill mismatch.

The intervention was designed for students who are about to complete pre-VET (i.e. at age 15-16 without grade interruptions or grade retention and depending on date of birth). The intervention was introduced in the academic year 2014-15 and also offered to consecutive cohorts. Since we lack the data for the cohorts 2015-16 and beyond, we restrict our analyses to those students who participated in the intervention in the academic year 2014-15.

Upon successful completion of pre-VET, students can enrol into STEM or another sector (health \& welfare, economics or agriculture) in VET. In 2014-15, the intervention was promoted among pre-VET students in the Amsterdam Metropolitan Area. The intervention is carried out in six training companies. In cooperation with the VETschools located in the Amsterdam Metropolitan Area, the training companies provide inschool practical training within the STEM programmes. The programme lasts five days and consists of a four-day module on professional orientation and a one-day generic module. ${ }^{25}$ The module on professional orientation introduces participants to STEM occupations with good labour market perspectives in the Amsterdam Metropolitan Area. These include occupations in the sectors building \& construction, installation \& electrical engineering, metal engineering, woodwork \& furniture, and motor vehicle engineering. During the intervention, students get acquainted with up to three of these STEM sectors. In the professional orientation module, students carry out different assignments that relate to the sectors of interest. Each assignment is related to multiple disciplines, e.g. carpentry combined with painting and finishing techniques or metal technology combined with installation technology. All assignments enable students to apply vocational knowledge to practice at different difficulty levels. For the generic module,

\footnotetext{
${ }^{25}$ Based on the preferences of the students and the school mentor, these five days could take place anytime in the schoolyear.
} 
participants are assessed on their cognitive, vocational, and interpersonal skills. Based on these assessment, participants are provided with education advice.

The intervention can affect students' choice to enrol into STEM education through various channels. First, the intervention serves as an opportunity for students to get hands-on-experience with a variety of STEM occupations which allows them to obtain a realistic view of what occupations entail. This might remove prejudices that students hold against certain occupations, but also provide insight into how occupations match students' tastes and preferences (Altonji et al., 2012; Wiswall \& Zafar, 2015a). Second, the intervention informs students about which STEM occupations match their ability and skills (Altonji et al., 2012; Jackson, 1982; Wiswall \& Zafar, 2015a). Finally, students are informed about the linkage between the skills learned in different STEM programmes and the labour market demand for such skills. Providing students with labour market information can alter students' expectations and subsequently affect their educational choices (Hastings et al., 2015; Jensen, 2010; McGuigan et al., 2016; Oreopoulos \& Dunn 2013; Wiswall \& Zafar, 2015a; Woods \& O’Leary, 2006).

\subsection{Identification strategy}

We estimate the effect of the five-day intervention on the likelihood of enrolment into a STEM programme in VET. Given that students were not randomly assigned to the intervention, we exploit the sudden and prompt way the intervention was implemented within a difference-in-differences (DiD) framework. An interview with one of the organizing training companies pointed out that the intervention was promoted at several pre-VET schools in the Amsterdam Metropolitan Area. The promotion of the intervention was targeted at schools that have a substantial share of students taking STEM subjects as they are most likely to enrol in STEM education in VET. ${ }^{26,27}$ The intervention was also promoted at open days of VET institutes and training companies. Because the intervention was promoted among a selective group of students, there were only few students who participated in the intervention and who lived outside the Amsterdam Metropolitan Area. ${ }^{28}$ As such, we can construct a control group from students who attended schools located outside the Amsterdam Metropolitan Area.

\footnotetext{
26 These schools were targeted given that another aim of the intervention was to improve the match between STEM programmes and students who were already interested in STEM education.

27 Information about the relation between STEM enrolment and the pre-VET background can be retrieved from www.doorstroomatlas-vmbo.nl.

28 This substantially reduces the likelihood that students who attended schools outside the Amsterdam Metropolitan Area were actually aware of the study choice programme. This was confirmed in an interview with one of the training companies.
} 
In the DiD model, we compare the outcomes of students in treated schools who graduated from pre-VET $(D=1)$ in the post-treatment period $(T=1)$ with the outcomes of untreated students $(D=0)$ in the pre-treatment period $(T=0)$. Furthermore, we compare students in the treated schools $(D=1)$ with students in untreated schools $(D=0)$ in the pre- and post-treatment period, respectively. The posttreatment period refers to the schoolyear 2014-15, while the pre-treatment period concerns the schoolyears 2011-12, 2012-13, and 2013-14. The DiD estimator is calculated as the difference in the average probability to enrol into STEM education in the treatment group before and after the intervention, minus the difference in the average likelihood to enrol into STEM in the control group before and after the treatment. The DiD baseline equation of interest is as follows:

$$
\text { STEM enrollment } \text { t }_{i}=\beta_{0}+\beta_{1} D_{j}+\beta_{2} T_{p}+\beta_{3}\left(D_{j} * T_{p}\right)+\beta_{4} X_{i j}+\varepsilon_{i}
$$

Here, the outcome variable STEM enrollment $_{i}$ equals 1 if student $i \in\{1,2, \ldots, N\}$ enrols in STEM in VET upon completion of pre-VET, and 0 otherwise. The treatment status of student $i$ is denoted by $D_{j}$. We will use two indicators for $D_{j}$. First, we use a binary treatment indicator where $D_{j}$ equals 1 if student $i$ attended school $j$ where at least one student participated in the intervention, and $D_{j}$ equals 0 if student $i$ attended a school where no students were exposed to the intervention. Second, we use a continuous treatment indicator where $D_{j}$ represents the percentage of male students in the final year of pre-VET who participated in the intervention at school $j$ of student $i$. Given that not every student in a treated school actually participates in the intervention, we estimate an intention-to-treat (ITT) effect. The time indicator is denoted by $T_{p}$ with $T=0$ indicating the pre-treatment period (2011-12, 2012-13, and 2013-14) and $T=1$ the post-treatment period (2014-15). Vector $X_{i j}$ constitutes a set of observable characteristics which will be introduced in the next section. The DiD estimator contains a treatment fixed effect $D_{j} \in\{0,1\}$ to account for all time invariant characteristics of the treatment and control schools. The DiD estimator also contains a time fixed effect $T_{p} \in\{0,1\}$ to control for factors that can cause the outcome to differ across cohorts (i.e. national policies that aim to increase enrolment into STEM). The main parameter of interest is $\beta_{3}$.

The DiD estimator relies on several assumptions. The first assumption concerns the common time trend (Bertrand, Duflo \& Mullainathan, 2004). This assumption implies that, in absence of the intervention, the average enrolment rate into STEM education moves parallel over time in the control and treatment group. In other words, the estimated effect is a direct result of the intervention and not of any other event. This 
should hold for native Dutch students as well as for students with an immigrant background. To formally test the parallel time trend assumption, we estimate an alternative difference-in-differences model including leads and lags. The analysis of leads enables us to test whether the trends in the pre-treatment are similar, while lags indicate whether the treatment effect changes after the introduction of the treatment (Autor, 2003). The following equation describes the model with leads and lags:

$$
\text { STEM enrollment }_{i}=\alpha_{0}+\alpha_{1} D_{j}+\sum_{t=2011}^{2014}\left(D_{j} * \text { Year }_{t}\right) \alpha_{2, t}+\alpha_{3} X_{i j}+\gamma_{t}+\varepsilon_{i}
$$

Here, the coefficients $\alpha_{2, t}$ represent the interactions between the indicator variables for each schoolyear and an indicator for whether a pre-VET school is treated or not. Whether the parallel time trend assumption holds will be discussed in the results section (Section 5).

The second assumption for the DiD estimation to hold is the Stable Unit Treatment Value (SUTVA) assumption. SUTVA deals with potential spill-over effects of the intervention from treated to untreated students. Spill-over effects from the treatment to the control group are minimized because, at the time of the intervention, treated and untreated students attended schools in different regions. As argued above, the control students attended schools outside the Amsterdam Metropolitan Area and they were unlikely to be aware of the intervention. Therefore, we argue that the SUTVAassumption is not violated.

It is important to point out that similar interventions might have taken place outside the Amsterdam Metropolitan Area that we are unaware of. However, the five-day programme was part of a large-scale intervention that was unique to the Amsterdam Metropolitan Area. Therefore, our study provides lower bound estimates of the effect of the intervention on STEM enrolment.

\subsection{Data and descriptive statistics}

This study uses the BRON data (Dutch: BasisRegister Onderwijsnummer). The BRON is an administrative dataset containing information on all students enrolled in Dutch secondary and higher education between 2003 and 2015. The data provides information on student-, school- and neighbourhood characteristics. The data offers information on students' gender, socio-economic background ${ }^{29}$, ethnicity ${ }^{30}$, and age. We also observe

\footnotetext{
29 The socio-economic indicator is constructed by the Netherlands Institute for Social Research (Sociaal en Cultureel Planbureau) in 2014 for each postal code and is based on the average income in a neighbourhood, the share of individuals with a low income, the share of individuals who are loweducated, and the share of individuals who are unemployed.
} 
numerous elements of students' school career, including the completed level in pre-VET, the average grade on central exams, whether a student received educational support in pre-VET (lwoo), whether students were enrolled in senior general secondary education (havo) or pre-university education (vwo) before completing pre-VET, whether students were tracked or not in the first year of lower secondary education (brugklas), and whether students took math, physics, economics or a second language in pre-VET. At the school level, we observe what share of students were enrolled in the theoretical track (vmbo theorische leerweg), the economics track, the agriculture track, the STEM track, the healthcare track, or the mixed track. Finally, we observe in which field-of-study students enrol in VET. The aforementioned variables constitute the control variables that are used to estimate Equations (1) and (2).

One drawback of the dataset is that we cannot identify participants at the individual level. Therefore, we rely on school-level information on the treatment participation status. In 2014, 294 students participated in the intervention who attended 56 different pre-VET schools. ${ }^{31}$ As we observe which schools participants attended, we can calculate the share of students that participated in the intervention in each of the 56 schools. Figure 4.1 shows frequency statistics on the share of students who participated in the intervention in the 56 schools. We observe that the share of students who participate in the intervention in a pre-VET school varies from 0.3 to 24 percent. ${ }^{32}$ It should be noted that schools with a relatively high share of participants were also subject to promotion of the intervention by the training companies. Participants who had very few peers at the pre-VET school who also participated in the intervention are more likely to have been informed about the intervention by having visited open days of VET institutes.

Table 4.1 describes the data. Out of the 126,048 native Dutch male students in our sample, 6.8 percent attended a treated pre-VET school. Out of the 33,762 male students with an immigrant background, 14.7 percent were enrolled in a pre-VET school in which students participated in the intervention. It is important to note that not all students who attended a treated school actually participated in the intervention. As outlined in the discussion of our identification strategy, we estimate an IT'T effect because we do not observe which students are treated within the treatment schools. On average, 43.1 percent of the Dutch male students enrol into STEM education after completing pre-

\footnotetext{
30 The data includes binary variables indicating whether at least one of the students' parents is born in Suriname, Aruba, Turkey, or Morocco. Moreover, we observe whether students have a non-Western or Western migrant background and we observe whether students have a first or second generation migrant background.

31 Appendix 4.1 shows where the treated schools are geographically located in the Netherlands.

32 Based on the information received from the training companies, the schools that were attended by the participants could be identified at the level of school establishments (6 digit BRIN).
} 
VET, while only 28.9 percent of the male students with an immigrant background enrol into STEM. The socio-economic status is on average lower for students with an immigrant background $(-0.83)$ than for Dutch native students $(-0.03)$. The average final grade on the national exam in pre-VET is 6.6 (on a scale from 1 to 10) for native Dutch students and 6.4 for students with an immigrant background. Students are on average 15 to 16 years old when they are enrolled in the final year of pre-VET.

\section{Figure 4.1: Share of male students in pre-VET schools participating in the intervention}

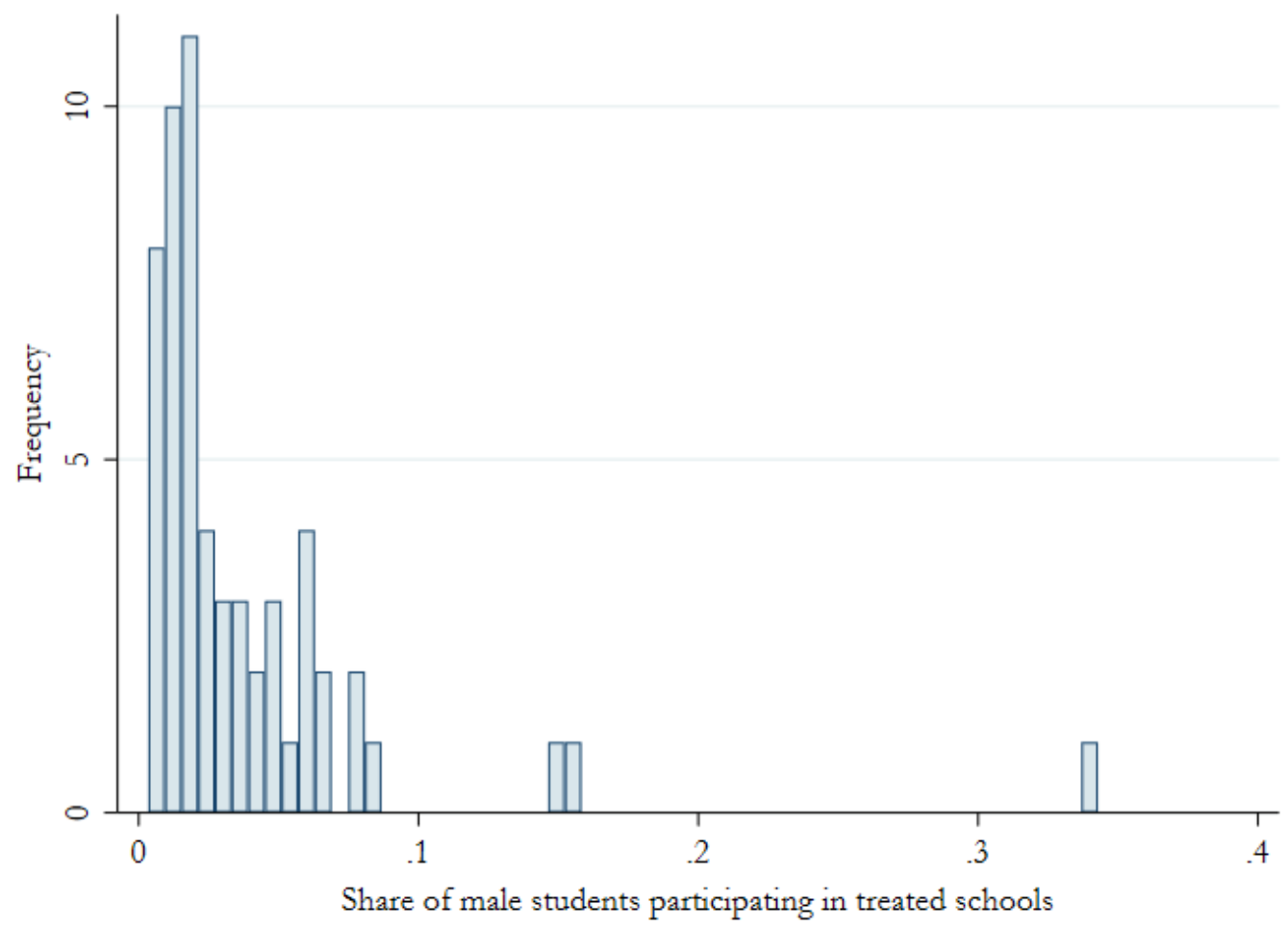

Moreover, a larger share of native Dutch male students took mathematics ( 90.8 percent) and physics (53.8 percent) in pre-VET compared to students with an immigrant background (86 percent and 35.1, respectively). In contrast, a larger share of students with an immigrant background took economics (63.3 percent) in pre-VET than native Dutch students (51.8 percent). The majority of students attend the highest track in preVET, the theoretical track (vmbo theoretische leerweg), while 29.1 percent attends the mixed track (vmbo gemengde leerweg), 21.6 percent follows the vocational oriented track (vmbo kaderberoepsgerichte leerweg), and 7.3 percent attends the lowest track in pre-VET (vmbo basisberoepsgerichte leerweg). 
Table 4.1: Descriptive statistics

\begin{tabular}{|c|c|c|c|c|c|c|c|c|c|c|}
\hline & \multicolumn{5}{|c|}{ Native students } & \multicolumn{5}{|c|}{ Students with an immigrant background } \\
\hline & Obs & Mean & Std. Dev. & Min & $\operatorname{Max}$ & Obs & Mean & Std. Dev. & Min & $\operatorname{Max}$ \\
\hline Treatment school & 126,048 & 0.068 & 0.252 & 0 & 1 & 33,762 & 0.147 & 0.354 & 0 & 1 \\
\hline Enrolment into STEM & 126,048 & 0.431 & 0.495 & 0 & 1 & 33,762 & 0.289 & 0.453 & 0 & 1 \\
\hline Socio-economic status indicator & 126,048 & -0.029 & 1.027 & -8.193 & 2.933 & 33,762 & -0.841 & 1.541 & -8.193 & 2.933 \\
\hline Student with additional support & 126,048 & 0.217 & 0.412 & 0 & 1 & 33,762 & 0.280 & 0.449 & 0 & 1 \\
\hline Grade point average & 126,048 & 6.554 & 0.452 & 5.5 & 9 & 33,762 & 6.440 & 0.422 & 5.5 & 8.7 \\
\hline Student attended havo & 126,048 & 0.077 & 0.267 & 0 & 1 & 33,762 & 0.057 & 0.232 & 0 & 1 \\
\hline Student attended vwo & 126,048 & 0.005 & 0.069 & 0 & 1 & 33,762 & 0.004 & 0.064 & 0 & 1 \\
\hline Student attended brugklas & 126,048 & 0.334 & 0.471 & 0 & 1 & 33,762 & 0.308 & 0.462 & 0 & 1 \\
\hline Age final year pre-VET & 126,048 & 15.462 & 0.591 & 14 & 20 & 33,762 & 15.649 & 0.682 & 14 & 20 \\
\hline Student took mathematics & 126,048 & 0.908 & 0.289 & 0 & 1 & 33,762 & 0.860 & 0.347 & 0 & 1 \\
\hline Student took physics & 126,048 & 0.538 & 0.499 & 0 & 1 & 33,762 & 0.351 & 0.477 & 0 & 1 \\
\hline Student took economics & 126,048 & 0.518 & 0.500 & 0 & 1 & 33,762 & 0.633 & 0.482 & 0 & 1 \\
\hline Student took second language & 126,048 & 0.212 & 0.408 & 0 & 1 & 33,762 & 0.217 & 0.413 & 0 & 1 \\
\hline vmbo basisberoepsgerichte leerweg & 126,048 & 0.073 & 0.260 & 0 & 1 & 33,762 & 0.035 & 0.184 & 0 & 1 \\
\hline vmbo kaderberoepsgerichte leerweg & 126,048 & 0.216 & 0.411 & 0 & 1 & 33,762 & 0.307 & 0.461 & 0 & 1 \\
\hline vmbo gemengde leernveg & 126,048 & 0.291 & 0.454 & 0 & 1 & 33,762 & 0.300 & 0.458 & 0 & 1 \\
\hline vmbo theoretische leerweg & 126,048 & 0.420 & 0.494 & 0 & 1 & 33,762 & 0.358 & 0.479 & 0 & 1 \\
\hline Percentage of students in theoretical track & 126,048 & 0.425 & 0.371 & 0 & 1 & 33,762 & 0.392 & 0.370 & 0 & 1 \\
\hline Percentage of students in economics track & 126,048 & 0.124 & 0.157 & 0 & 1 & 33,762 & 0.180 & 0.201 & 0 & 1 \\
\hline Percentage of students in agriculture track & 126,048 & 0.083 & 0.255 & 0 & 1 & 33,762 & 0.029 & 0.152 & 0 & 1 \\
\hline Percentage of students in STEM track & 126,048 & 0.240 & 0.264 & 0 & 1 & 33,762 & 0.221 & 0.253 & 0 & 1 \\
\hline Percentage of students in healthcare track & 126,048 & 0.029 & 0.052 & 0 & 1 & 33,762 & 0.032 & 0.058 & 0 & 1 \\
\hline Percentage of students in mixed track & 126,048 & 0.098 & 0.188 & 0 & 1 & 33,762 & 0.145 & 0.229 & 0 & 1 \\
\hline Suriname & & & & & & 33,762 & 0.124 & 0.330 & 0 & 1 \\
\hline Aruba & & & & & & 33,762 & 0.053 & 0.225 & 0 & 1 \\
\hline Turkey & & & & & & 33,762 & 0.200 & 0.400 & 0 & 1 \\
\hline Morocco & & & & & & 33,762 & 0.165 & 0.372 & 0 & 1 \\
\hline Non western immigrant background & & & & & & 33,762 & 0.206 & 0.405 & 0 & 1 \\
\hline Western immigrant background & & & & & & 33,762 & 0.249 & 0.433 & 0 & 1 \\
\hline First generation migrant & & & & & & 33,762 & 0.166 & 0.372 & 0 & 1 \\
\hline Second generation migrant & & & & & & 33,762 & 0.833 & 0.373 & 0 & 1 \\
\hline
\end{tabular}


The average percentage of Dutch native students attending the theoretical track is 42 percent and 35.8 percent for students with an immigrant background. Finally, Table 4.1 shows that the average share of native Dutch students who were enrolled in the STEM track in pre-VET is 24 percent. For male students with an immigrant background, the average share of students enrolled into a STEM track in pre-VET is 22.1 percent.

\subsection{Results}

Before turning to the main findings, we show the results of the leads and lags analysis. Table 4.2 shows that Native Dutch male students in treated and untreated schools were behaving similarly before the introduction of the intervention in 2014-15. The coefficients are small and not statistically significant. For immigrant background students, the interaction between the 2011-12 indicator and the treatment indicator is significant. This implies that the trend in terms of STEM enrolment is only parallel in the two years prior to the intervention. Therefore, as a robustness check, we will apply propensity score matching to balance the control and treatment group on a set of characteristics that influence the probability of receiving the treatment (see Robustness section).

\section{Table 4.2: Difference-in-differences with leads and lags}

\begin{tabular}{lcc}
\hline \hline & Native students & Immigrant background students \\
\hline Treated school * 2011-12 & -0.000 & $0.042^{* *}$ \\
& $(0.016)$ & $(0.020)$ \\
Treated school $* 2012-13$ & -0.013 & 0.001 \\
& $(0.015)$ & $(0.017)$ \\
Treated school * 2014-15 & -0.010 & 0.021 \\
& $(0.014)$ & $(0.019)$ \\
\hline Controls & $\mathrm{X}$ & $\mathrm{X}$ \\
Treatment fixed effect & $\mathrm{X}$ & $\mathrm{X}$ \\
Year fixed effects & $\mathrm{X}$ & $\mathrm{X}$ \\
Number of clusters & 888 & 877 \\
Observations & 126,048 & 33,762 \\
$\mathrm{R}^{2}$ & 0.230 & 0.207 \\
\hline \hline
\end{tabular}

Notes: The reference year is 2013-14. Standard errors clustered at the school level are in parentheses. Asterisks indicate significance levels: ${ }^{*} \mathrm{p}<0.10,{ }^{* *} \mathrm{p}<0.05,{ }^{* * *} \mathrm{p}<0.01$.

Table 4.3 presents the results of the DiD-estimates. Models 1a, 1b, 3a and $3 \mathrm{~b}$ in Table 4.3 show the DiD-estimates with a binary indicator for having received the treatment. Models $2 \mathrm{a}, 2 \mathrm{~b}, 4 \mathrm{a}$ and $4 \mathrm{~b}$ present the DiD-estimates with a continuous indicator for having received the treatment. Models $1 \mathrm{a}, 2 \mathrm{a}, 3 \mathrm{a}$ and $4 \mathrm{a}$ show the results without control variables and models $1 \mathrm{~b}, 2 \mathrm{~b}, 3 \mathrm{~b}$ and $4 \mathrm{~b}$ present the estimates when all control variables are included. 
Table 4.3: Difference-in-differences estimates

\begin{tabular}{|c|c|c|c|c|c|c|c|c|}
\hline & \multicolumn{4}{|c|}{ Native students } & \multicolumn{4}{|c|}{ "Migrant background students } \\
\hline & model(1a) & model(1b) & $\operatorname{model}(2 \mathrm{a})$ & $\operatorname{model}(2 \mathrm{~b})$ & model(3a) & $\operatorname{model}(3 b)$ & $\operatorname{model}(4 a)$ & $\operatorname{model}(4 b)$ \\
\hline Treated school $*$ Time & $\begin{array}{l}-0.019 \\
(0.017)\end{array}$ & $\begin{array}{l}-0.006 \\
(0.012)\end{array}$ & & & $\begin{array}{l}-0.008 \\
(0.019)\end{array}$ & $\begin{array}{c}0.009 \\
(0.018)\end{array}$ & & \\
\hline Share of male participants in school $*$ Time & & & $\begin{array}{l}-0.002 \\
(0.002)\end{array}$ & $\begin{array}{l}-0.001 \\
(0.002)\end{array}$ & & & $\begin{array}{c}0.005 \\
(0.003)\end{array}$ & $\begin{array}{c}0.006 * * \\
(0.002)\end{array}$ \\
\hline Treatment fixed effect & $\mathrm{X}$ & $\mathrm{X}$ & & & $\mathrm{X}$ & $\mathrm{X}$ & & \\
\hline Share of male participants in school & & & $\mathrm{X}$ & $\mathrm{X}$ & & & $\mathrm{X}$ & $\mathrm{X}$ \\
\hline Time fixed effect & $\mathrm{X}$ & $\mathrm{X}$ & $\mathrm{X}$ & $\mathrm{X}$ & $\mathrm{X}$ & $\mathrm{X}$ & $\mathrm{X}$ & $\mathrm{X}$ \\
\hline \multicolumn{9}{|l|}{ Control variables } \\
\hline Socio-economic status indicator & & $\mathrm{X}$ & & $\mathrm{X}$ & & $\mathrm{X}$ & & $\mathrm{X}$ \\
\hline Student with additional support & & $\mathrm{X}$ & & $\mathrm{X}$ & & $\mathrm{X}$ & & $\mathrm{X}$ \\
\hline Grade point average & & $\mathrm{X}$ & & $\mathrm{X}$ & & $\mathrm{X}$ & & $\mathrm{X}$ \\
\hline Student attended havo & & $\mathrm{X}$ & & $\mathrm{X}$ & & $\mathrm{X}$ & & $\mathrm{X}$ \\
\hline Student attended vwo & & $\mathrm{X}$ & & $\mathrm{X}$ & & $\mathrm{X}$ & & $\mathrm{X}$ \\
\hline Student attended brugkelas & & $\mathrm{X}$ & & $\mathrm{X}$ & & $\mathrm{X}$ & & $\mathrm{X}$ \\
\hline Age final year pre-VET & & $\mathrm{X}$ & & $\mathrm{X}$ & & $\mathrm{X}$ & & $\mathrm{X}$ \\
\hline Student took mathematics & & $\mathrm{X}$ & & $\mathrm{X}$ & & $\mathrm{X}$ & & $\mathrm{X}$ \\
\hline Student took physics & & $\mathrm{X}$ & & $\mathrm{X}$ & & $\mathrm{X}$ & & $\mathrm{X}$ \\
\hline Student took economics & & $\mathrm{X}$ & & $\mathrm{X}$ & & $\mathrm{X}$ & & $\mathrm{X}$ \\
\hline Student took second language & & $\mathrm{X}$ & & $\mathrm{X}$ & & $\mathrm{X}$ & & $\mathrm{X}$ \\
\hline Level of education in pre-VET & & $\mathrm{X}$ & & $\mathrm{X}$ & & $\mathrm{X}$ & & $\mathrm{X}$ \\
\hline Educational sector in pre-VET & & $\mathrm{X}$ & & $\mathrm{X}$ & & $\mathrm{X}$ & & $\mathrm{X}$ \\
\hline \multicolumn{9}{|l|}{ Migrant background } \\
\hline Suriname & & & & & & $\mathrm{X}$ & & $\mathrm{X}$ \\
\hline Aruba & & & & & & $\mathrm{X}$ & & $\mathrm{X}$ \\
\hline Turkey & & & & & & $\mathrm{X}$ & & $\mathrm{X}$ \\
\hline Morocco & & & & & & $\mathrm{X}$ & & $\mathrm{X}$ \\
\hline Non western immigrant background & & & & & & $\mathrm{X}$ & & $\mathrm{X}$ \\
\hline Western immigrant background & & & & & & $\mathrm{X}$ & & $\mathrm{X}$ \\
\hline First generation immigrant (ref. category) & & & & & & $\mathrm{X}$ & & $\mathrm{X}$ \\
\hline Second generation immigrant & & & & & & $\mathrm{X}$ & & $\mathrm{X}$ \\
\hline Number of clusters & 888 & 888 & 888 & 888 & 877 & 877 & 877 & 877 \\
\hline Observations & 126,048 & 126,048 & 126,048 & 126,048 & 33,762 & 33,762 & 33,762 & 33,762 \\
\hline$R^{2}$ & 0.000 & 0.230 & 0.002 & 0.230 & 0.002 & 0.208 & 0.001 & 0.208 \\
\hline
\end{tabular}

Notes: Standard errors clustered at the school level are in parentheses. Asterisks indicate significance levels: ${ }^{*} \mathrm{p}<0.10, * * \mathrm{p}<0.05, * * * \mathrm{p}<0.01$. 
The estimates are presented seperately for native Dutch students (models 1a, 1b, 2a and 2b) and students with an immigrant background (models 3a, 3b, 4a and 4b). Given that in some schools, only few students participated in the intervention (Figure 4.1), our preferred specification includes the continuous treatment indicator.

Table 4.3 shows that native Dutch students who attended a treatment school are 0.6 percentage points less likely to enrol into STEM education than students who attended an untreated school (model 1b). However, the difference is not statistically different from zero. Similarly, a 1 percentage point increase in the share of students who participated in the intervention in students' pre-VET school does not increase native Dutch students' likelihood to enrol into STEM (model $2 \mathrm{~b}$ ). Hence, the results in model $1 \mathrm{~b}$ cannot be explained by the fact that many schools had a very small percentage of students who participated in the intervention (Figure 4.1).

For students with an immigrant background who attended a treated school, the likelihood to enrol into STEM education is 0.9 percentage points larger than for students who have attended an untreated school (model 3b). However, the effect is not statistically significant. Only model $4 \mathrm{~b}$ provides a significant ITT estimate. The continuous indicator shows that a one percentage point increase in the share of students that participated in the intervention in the pre-VET school, increases the likelihood that students with an immigrant background enrol into STEM education with 0.6 percentage points.

\subsection{Robustness}

As a robustness check, we account for differences in background characteristics between treated and untreated students by applying propensity score matching. The matching technique allows us to balance the control and treatment groups with respect to characteristics that could simultaneously affect the likelihood that a student participates in the intervention and enrols into STEM education. In order to accommodate the Conditional Independence Assumption (CLA), we match students in treated and untreated schools on all available observed pre-treatment characteristics. The CIA assumption states that, conditional on the observable pre-treatment variables $X_{i j}$, participation in the intervention is independent of the potential outcomes (Angrist \& Pischke, 2008). We apply the Nearest Neighbour (NN) one-to-one propensity score matching technique and perform 1,000 replications with random sorting of the data. ${ }^{33}$ Due to the richness of the data, we have a large pool of potential control observations. This is in favour of the NN-matching of students without replacement.

33 The randomization ensures that the estimates do not depend on the order in which observations are matched. 
We choose for a caliper close to zero (i.e. 0.001) in order to guarantee that the differences between the propensity scores of treated and untreated students are small. ${ }^{34}$ The average estimated ITT for native Dutch students when using the binary treatment indicator is 0.1 percentage points (0.001) and has a standard deviation of 0.001 . The 95 percent confidence interval [min: -0.001., max: 0.0003] contains zero. We conclude that the ITT estimate is qualitatively similar to the small and insignificant effect obtained in the unmatched sample (-0.006). The average estimated ITT obtained after NN-matching when using the continuous treatment indicator is -0.01 percentage points $(-0.0001)$ with a standard deviation of 0.00004 . This is qualitatively similar to the estimate obtained when using the continuous treatment indicator in the unmatched sample $(-0.001)$. The size of the obtained estimate is almost negligible. Hence, the findings suggest that the intervention did not affect native Dutch students' probability to choose for STEM.

The average estimated intent-to-treat effect for students with an immigrant background when using the binary treatment indicator is -1.5 percentage points (-0.015) with a standard deviation of 0.002 . The ITT estimate obtained in the unmatched sample is qualitatively different (0.005) and, therefore, not robust. In contrast, the ITT estimates after NN-matching are highly comparable to the estimates obtained on the unmatched sample when a continuous indicator is used. The average estimated ITT for students with an immigrant background when using the continuous treatment indicator is 0.5 percentage points (0.005) and has a standard deviation of 0.0002 . The range of estimates does not include zero [min: 0.005, max: 0.007]. We conclude that the estimates obtained after NN-matching are qualitatively similar to the estimate obtained in the unmatched sample (0.006). Because our preferred specification contains the continuous treatment indicator, we conclude that the intervention has had a small but significant effect on the likelihood that students with an immigrant background enrol into STEM.

\subsection{Conclusion and discussion}

Although the demand for STEM graduates has been increasing in most European countries, the share of students graduating from STEM in VET has declined in recent years. Despite the fact that there are numerous studies examining the effectiveness of interventions aimed at increasing enrolment rates into STEM education, none of these studies focused on actual enrolment rates into STEM. Moreover, most studies focus on interventions that are designed to motivate students to enrol into STEM in higher education. This study evaluates the effectiveness of a five-day intervention designed for pre-VET students with the aim to increase enrolment into STEM in VET.

34 Figures of the empirical distribution of the estimated intent-to-treat (ITT) effects based on the 1,000 samples that are obtained after NN-matching can be found in Appendix 4.2. 
Our findings suggest that the intervention had no effect on native Dutch male students. A potential explanation for why the intervention had no significant effect on native students is that the intervention was targeted at pre-VET schools in which a large share of students were enrolled in a STEM track. These students might have enrolled into STEM even in absence of the intervention. In contrast, our findings show that the five-day programme had a small, but significant effect on male students with an immigrant background. A 1 percentage point increase in the share of students at the pre-VET school participating in the intervention significantly increased the likelihood of enrolling into STEM with 0.6 percentage points. It is important to note that this is an estimate of the ITT as we do not observe which students in the treatment schools actually received the treatment. Hence, the average treatment effect on the treated (ATE) is likely to be larger than our estimated IT'T .

Although the data do not allow us to explore the underlying mechanisms of the positive effect on immigrant background students, we can provide a number of potential explanations based on the literature. Immigrant background students, as well as their parents, tend to have negative associations with STEM occupations because such occupations have a low status in the country of origin (De Koning et al., 2010). Moreover, students with an immigrant background are less likely to believe that they have the ability to successfully complete a STEM programme (MacPhee et al., 2013). Therefore, the discrepancy between students' beliefs and their actual preferences and ability could potentially be larger for immigrant background students. The intervention might have updated the beliefs of migrant students regarding their ability and preferences by experiencing STEM occupations through hands-on-activities (De Koning et al., 2010; Kuijpers \& Meijers, 2009). Moreover, migrant students and their parents tend to be less well-informed about the labour market perspectives of STEM programmes (De Koning et al., 2010). The larger information gap among students with an immigrant background might be another explanation for why the intervention only had a significant effect on immigrant background students. Earlier research shows that students from lower socioeconomic backgrounds, who also have a relatively large information gap, tend to be more sensitive to labour market information (Hoxby \& Turner, 2013; Wiswall \& Zafar, 2015b). Future research must point out whether these potential explanations are in fact the mechanisms that explain why the intervention only had an effect on a selective group of immigrant background students.

Based on our findings, we can draw several policy implications and provide guidelines for future research. The intervention is likely to have had no significant effect on native students, and only a small effect on immigrant background students, due to the selective sample of participants. Hence, future interventions should be targeted at students who do 


\section{Chapter 4}

not already show a clear interest in STEM or who are in doubt as to whether STEM matches their preferences and ability. Because students choose to enrol into a specific track in the third year of pre-VET, future interventions should trigger students' interest for STEM at an earlier stage in their educational career (De Philippis, 2017). Apart from increasing enrolment into STEM education, the intervention also aimed at improving the match between STEM study programmes and students who were already interested in STEM. While our dataset does not enable us to observe treated students in the second year of VET, it is reasonable to expect that the intervention increased the likelihood that treated students complete the STEM study programme in which they enrolled after the intervention. Future research should point out if this is actually the case. Finally, the fiveday programme ideally also increases the likelihood that participants end up in STEM jobs in the labour market. Matching vacancies for STEM jobs with STEM graduates remains a challenge in the Netherlands as an increasing share of STEM graduates end up in jobs that are unrelated to the attended field-of-study (ROA, 2017a). 
Appendix 4.1: Geographical distribution of treated and untreated schools

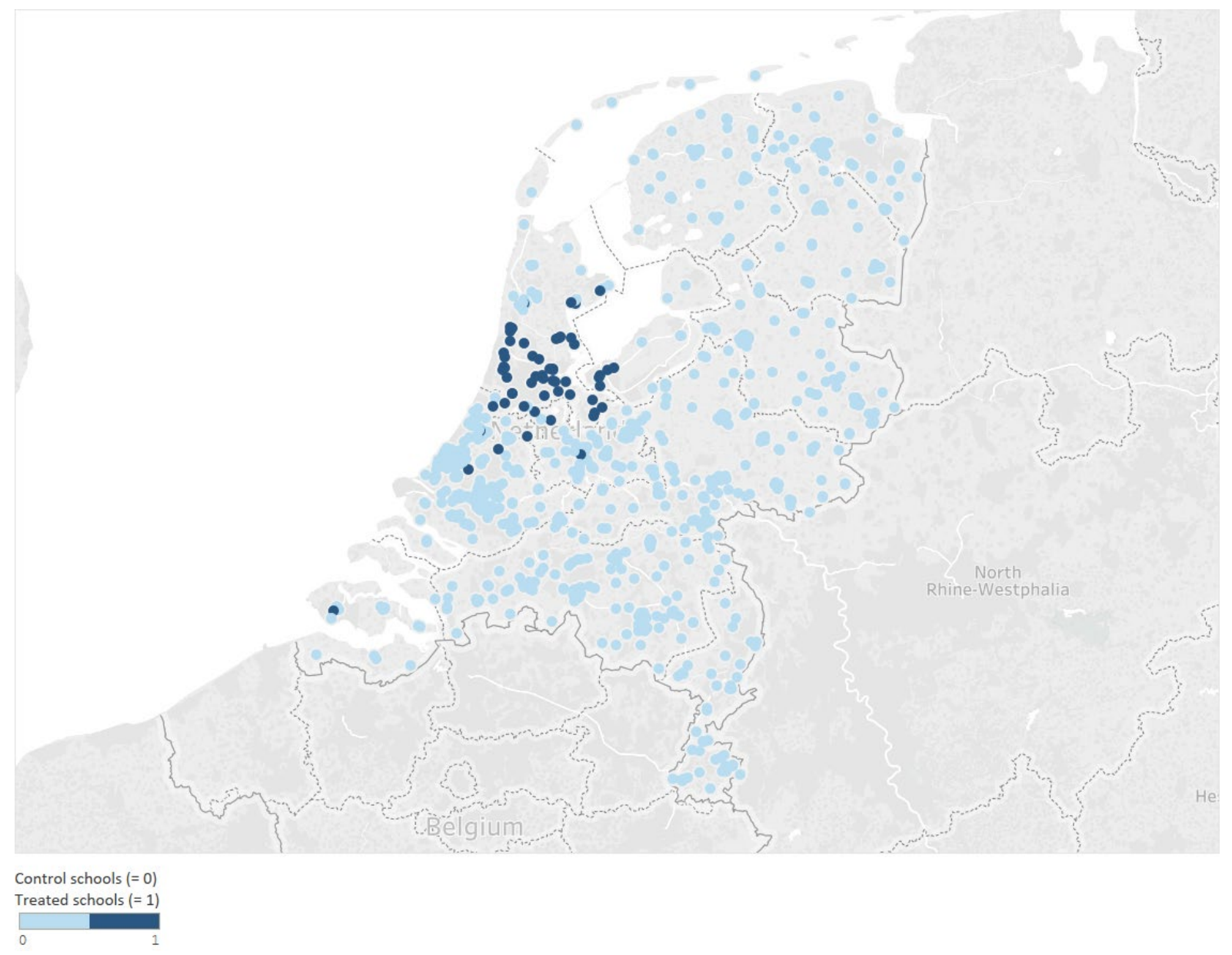


Appendix 4.2: Empirical distribution of the estimated intent-to-treat (ITT) effects

Figure 4.2: Empirical distribution of the ITT for native Dutch male students when a binary treatment indicator is used and all control variables are included

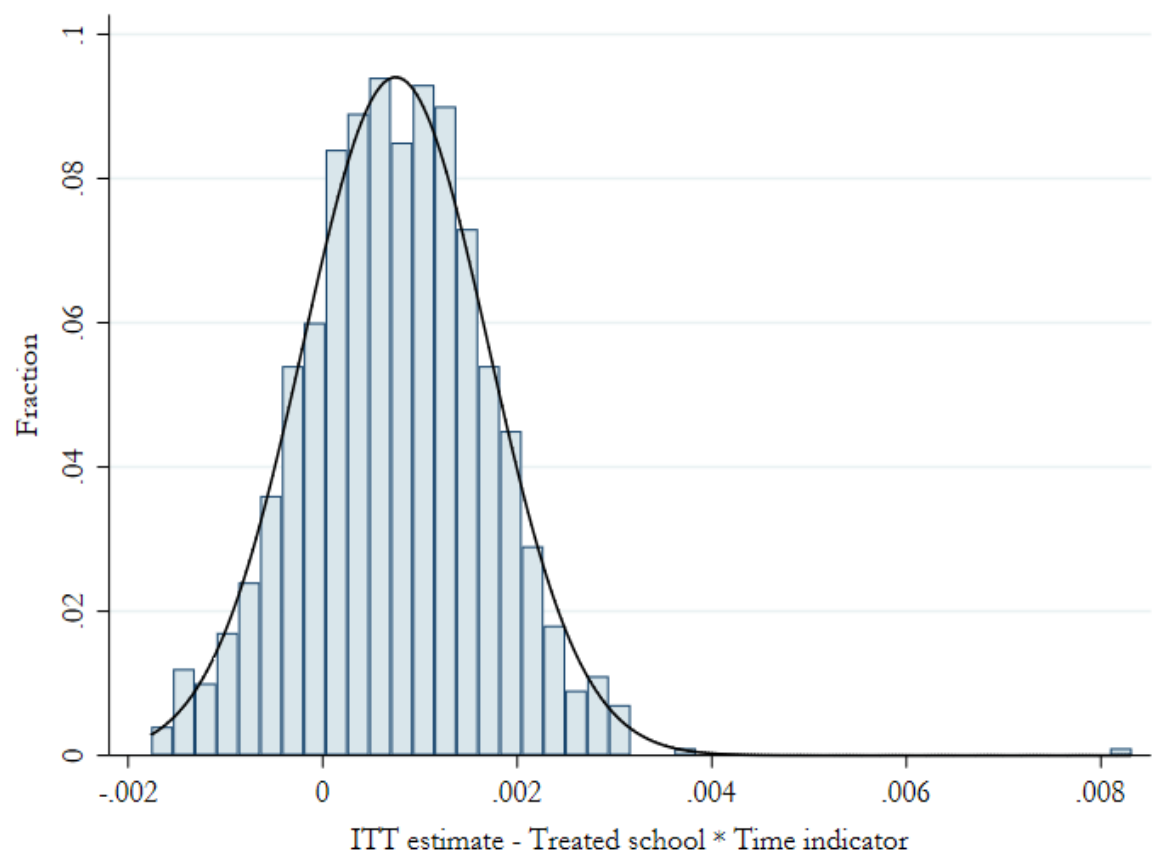

Notes: The ITT effects are estimated on 1,000 samples constructed by Nearest Neighbor matching without replacement and a caliper of 0.001 (Normal distribution plot added to the graph).

Figure 4.3: Empirical distribution of the ITT for native Dutch male students when a continuous treatment indicator is used and all control variables are included

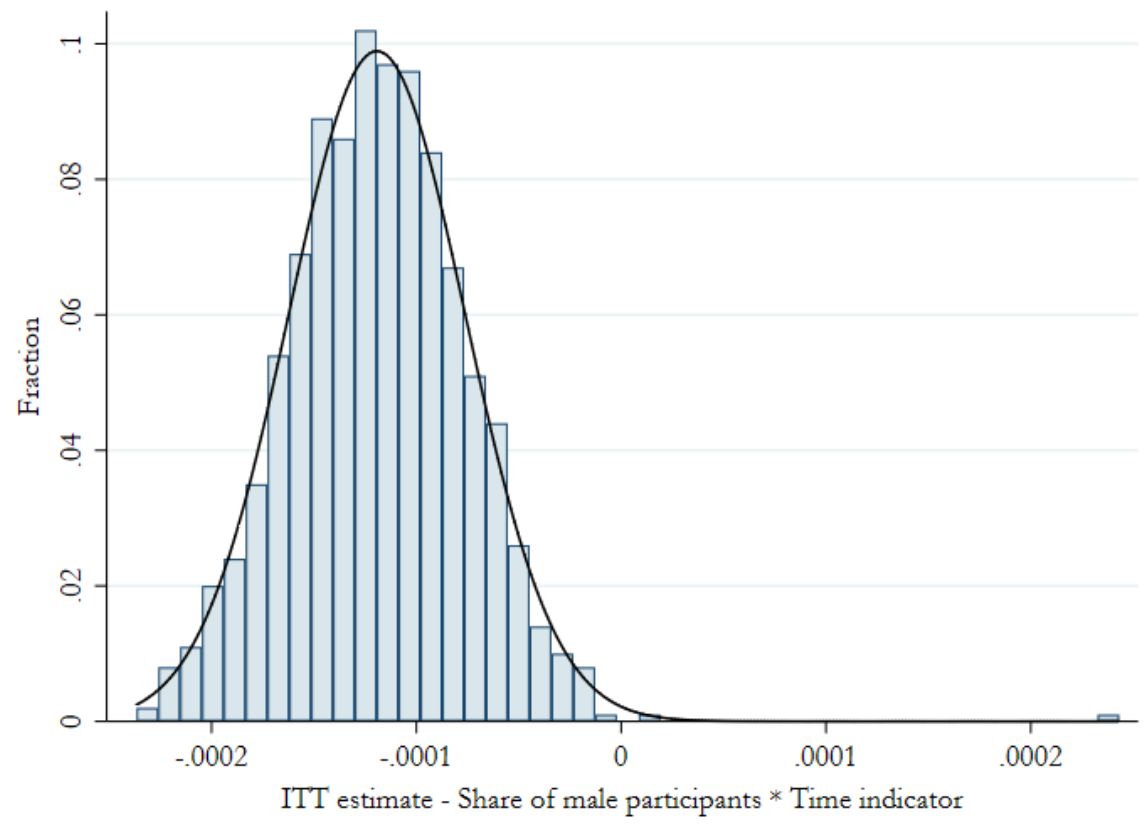

Notes: The ITT effects are estimated on 1,000 samples constructed by Nearest Neighbor matching without replacement and a caliper of 0.001 (Normal distribution plot added to the graph). 
Figure 4.4: Empirical distribution of the ITT for immigrant background students when a binary treatment indicator is used and all control variables are included

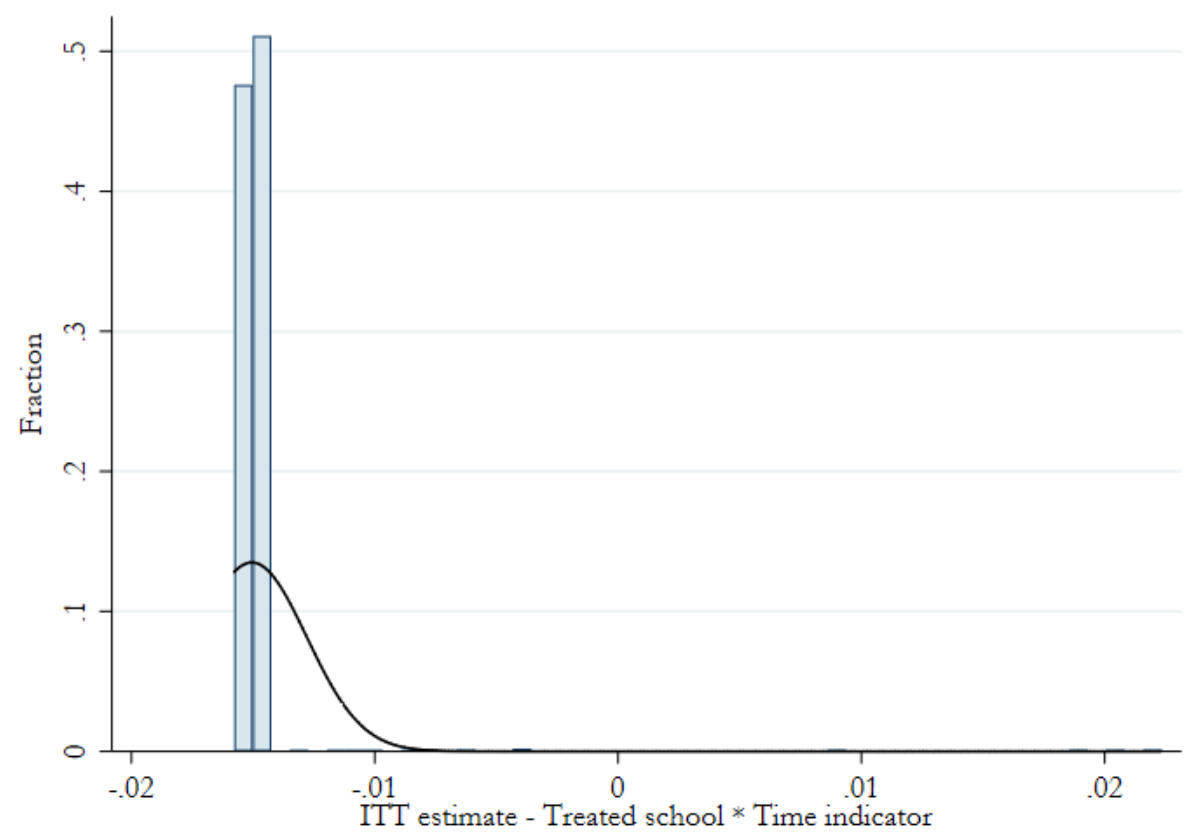

Notes: The ITT effects are estimated on 1,000 samples constructed by Nearest Neighbor matching without replacement and a caliper of 0.001 (Normal distribution plot added to the graph).

Figure 4.5: Empirical distribution of the ITT for immigrant background students when a continuous treatment indicator is used and all control variables are included

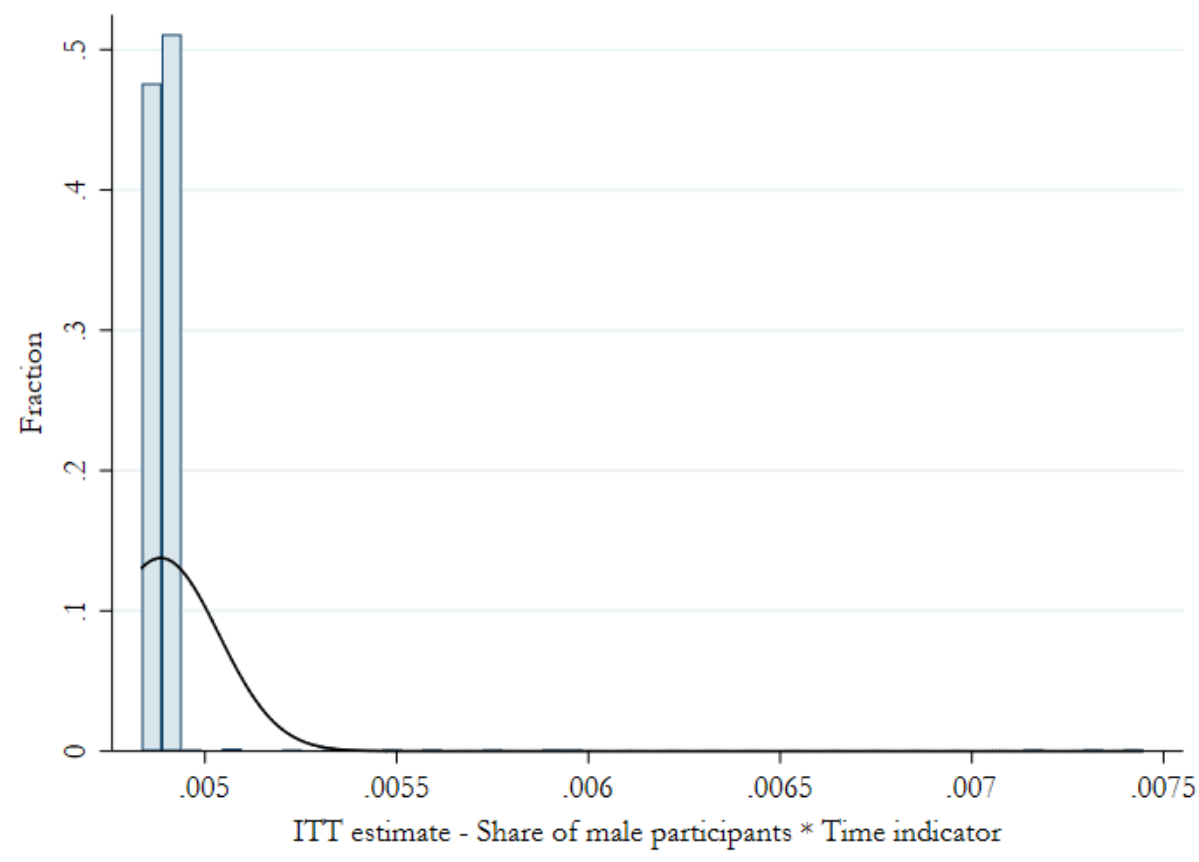

Notes: The ITT effects are estimated on 1,000 samples constructed by Nearest Neighbor matching without replacement and a caliper of 0.001 (Normal distribution plot added to the graph). 


\section{Appendix 4.3: Difference-in-differences estimates full table}

Table 4.4: Difference-in-differences estimates full table

\begin{tabular}{|c|c|c|c|c|c|c|c|c|}
\hline & \multicolumn{4}{|c|}{ Native students } & \multicolumn{4}{|c|}{ Migrant background students } \\
\hline & $\operatorname{model}(1 \mathrm{a})$ & model $(1 b)$ & $\operatorname{model}(2 \mathrm{a})$ & $\operatorname{model}(2 \mathrm{~b})$ & $\operatorname{model}(3 a)$ & $\operatorname{model}(3 \mathrm{~b})$ & $\operatorname{model}(4 a)$ & $\operatorname{model}(4 \mathrm{~b})$ \\
\hline Treated school $*$ Time & $\begin{array}{l}-0.019 \\
(0.017)\end{array}$ & $\begin{array}{l}-0.006 \\
(0.012)\end{array}$ & & & $\begin{array}{l}-0.008 \\
(0.019)\end{array}$ & $\begin{array}{c}0.009 \\
(0.018)\end{array}$ & & \\
\hline Share of male participants in school ${ }^{*}$ Time & & & $\begin{array}{l}-0.002 \\
(0.002)\end{array}$ & $\begin{array}{l}-0.001 \\
(0.002)\end{array}$ & & & $\begin{array}{c}0.005 \\
(0.003)\end{array}$ & $\begin{array}{c}0.006 * * \\
(0.002)\end{array}$ \\
\hline Treatment dummy & $\begin{array}{c}0.018 \\
(0.024)\end{array}$ & $\begin{array}{l}-0.014 \\
(0.009)\end{array}$ & & & $\begin{array}{c}-0.037 * * \\
(0.015)\end{array}$ & $\begin{array}{c}-0.026^{* *} \\
(0.012)\end{array}$ & & \\
\hline Share of male participants in school & & & $\begin{array}{c}1.073 * * * \\
(0.133)\end{array}$ & $\begin{array}{c}0.030 \\
(0.169)\end{array}$ & & & $\begin{array}{l}-0.030 \\
(0.457)\end{array}$ & $\begin{array}{c}-0.553^{*} \\
(0.320)\end{array}$ \\
\hline Dummy year 2011-12 & $\begin{array}{c}0.005 \\
(0.005)\end{array}$ & $\begin{array}{l}-0.004 \\
(0.004)\end{array}$ & $\begin{array}{c}0.006 \\
(0.005)\end{array}$ & $\begin{array}{l}-0.004 \\
(0.004)\end{array}$ & $\begin{array}{c}-0.023 * * * \\
(0.009)\end{array}$ & $\begin{array}{c}-0.027 * * * \\
(0.007)\end{array}$ & $\begin{array}{c}-0.022^{* * *} \\
(0.008)\end{array}$ & $\begin{array}{c}-0.027 * * * \\
(0.007)\end{array}$ \\
\hline Dummy year 2012-13 & $\begin{array}{c}-0.012 * * * \\
(0.004)\end{array}$ & $\begin{array}{c}-0.011 * * * \\
(0.004)\end{array}$ & $\begin{array}{c}-0.012 * * * \\
(0.004)\end{array}$ & $\begin{array}{c}-0.011 * * * \\
(0.004)\end{array}$ & $\begin{array}{c}-0.031 * * * \\
(0.008)\end{array}$ & $\begin{array}{c}-0.028 * * * \\
(0.006)\end{array}$ & $\begin{array}{c}-0.030^{* * *} \\
(0.008)\end{array}$ & $\begin{array}{c}-0.028^{* * *} \\
(0.006)\end{array}$ \\
\hline Dummy year 2014-15 & $\begin{array}{c}0.001 \\
(0.005) \\
\end{array}$ & $\begin{array}{l}-0.004 \\
(0.004) \\
\end{array}$ & $\begin{array}{c}0.001 \\
(0.005) \\
\end{array}$ & $\begin{array}{l}-0.004 \\
(0.004)\end{array}$ & $\begin{array}{c}0.009 \\
(0.008) \\
\end{array}$ & $\begin{array}{l}-0.002 \\
(0.007) \\
\end{array}$ & $\begin{array}{c}0.005 \\
(0.008) \\
\end{array}$ & $\begin{array}{l}-0.004 \\
(0.007) \\
\end{array}$ \\
\hline Control variables & & & & & & & & \\
\hline Socio-economic status indicator & & $\begin{array}{c}0.011 * * * \\
(0.002)\end{array}$ & & $\begin{array}{c}0.010^{* * *} \\
(0.002)\end{array}$ & & $\begin{array}{l}-0.002 \\
(0.002)\end{array}$ & & $\begin{array}{l}-0.002 \\
(0.002)\end{array}$ \\
\hline Student with additional support & & $\begin{array}{c}0.014 * * * \\
(0.004)\end{array}$ & & $\begin{array}{c}0.014^{* * *} * \\
(0.004)\end{array}$ & & $\begin{array}{c}0.018^{* * *} \\
(0.006)\end{array}$ & & $\begin{array}{c}0.018^{* * *} \\
(0.006)\end{array}$ \\
\hline Grade point average & & $\begin{array}{c}0.041 * * * \\
(0.003)\end{array}$ & & $\begin{array}{c}0.041 * * * \\
(0.003)\end{array}$ & & $\begin{array}{c}0.037 * * * \\
(0.006)\end{array}$ & & $\begin{array}{c}0.037 * * * \\
(0.006)\end{array}$ \\
\hline Student attended havo & & $\begin{array}{c}-0.015^{* *} \\
(0.006)\end{array}$ & & $\begin{array}{c}-0.015^{* *} \\
(0.006)\end{array}$ & & $\begin{array}{l}-0.014 \\
(0.010)\end{array}$ & & $\begin{array}{l}-0.015 \\
(0.010)\end{array}$ \\
\hline Student attended vwo & & $\begin{array}{c}-0.041^{* *} \\
(0.020)\end{array}$ & & $\begin{array}{c}-0.041 * * \\
(0.020)\end{array}$ & & $\begin{array}{c}0.040 \\
(0.040)\end{array}$ & & $\begin{array}{c}0.040 \\
(0.040)\end{array}$ \\
\hline Student attended brugkelas & & $\begin{array}{c}-0.011^{* *} \\
(0.005)\end{array}$ & & $\begin{array}{c}-0.010^{* *} \\
(0.005)\end{array}$ & & $\begin{array}{c}-0.015^{* *} \\
(0.007)\end{array}$ & & $\begin{array}{c}-0.015^{* *} \\
(0.007)\end{array}$ \\
\hline Age final year pre-VET & & $\begin{array}{c}0.004 * * \\
(0.002)\end{array}$ & & $\begin{array}{c}0.004 * * \\
(0.002)\end{array}$ & & $\begin{array}{c}0.009 * * \\
(0.004)\end{array}$ & & $\begin{array}{c}0.009 * * * \\
(0.004)\end{array}$ \\
\hline
\end{tabular}


Table 4.4 (continued)

\begin{tabular}{|c|c|c|c|c|}
\hline Student took mathematics & $\begin{array}{c}0.034 * * * \\
(0.007)\end{array}$ & $\begin{array}{c}0.034 * * * \\
(0.007)\end{array}$ & $\begin{array}{c}0.034 * * * \\
(0.008)\end{array}$ & $\begin{array}{c}0.034 * * * \\
(0.008)\end{array}$ \\
\hline Student took physics & $\begin{array}{c}0.388^{* * *} \\
(0.007)\end{array}$ & $\begin{array}{c}0.388^{* * *} \\
(0.007)\end{array}$ & $\begin{array}{c}0.338^{* * *} \\
(0.010)\end{array}$ & $\begin{array}{c}0.339 * * * \\
(0.010)\end{array}$ \\
\hline Student took economics & $\begin{array}{c}-0.096^{* * *} \\
(0.006)\end{array}$ & $\begin{array}{c}-0.096 * * * \\
(0.006)\end{array}$ & $\begin{array}{c}-0.117^{* * *} \\
(0.008)\end{array}$ & $\begin{array}{c}-0.117^{* * *} \\
(0.008)\end{array}$ \\
\hline Student took second & $\begin{array}{l}-0.001 \\
(0.005)\end{array}$ & $\begin{array}{l}-0.001 \\
(0.005)\end{array}$ & $\begin{array}{l}-0.011 \\
(0.008)\end{array}$ & $\begin{array}{l}-0.011 \\
(0.008)\end{array}$ \\
\hline $\begin{array}{l}\text { Level of education in pre- } \\
\text { vmbo theoretische leerweg (ref. }\end{array}$ & $\begin{array}{c}0.000 \\
(0.000)\end{array}$ & $\begin{array}{c}0.000 \\
(0.000)\end{array}$ & $\begin{array}{c}0.000 \\
(0.000)\end{array}$ & $\begin{array}{c}0.000 \\
(0.000)\end{array}$ \\
\hline vmbo gemengde leerweg & $\begin{array}{c}-0.009 * \\
(0.005)\end{array}$ & $\begin{array}{c}-0.009^{*} \\
(0.005)\end{array}$ & $\begin{array}{c}0.015^{* *} \\
(0.007)\end{array}$ & $\begin{array}{c}0.015^{* *} \\
(0.007)\end{array}$ \\
\hline vmbo Kadergerichte leerweg & $\begin{array}{c}-0.026^{* * *} \\
(0.010)\end{array}$ & $\begin{array}{c}-0.026^{* * *} \\
(0.010)\end{array}$ & $\begin{array}{l}0.032 * \\
(0.017)\end{array}$ & $\begin{array}{l}0.034^{*} \\
(0.018)\end{array}$ \\
\hline vmbo basisberoepsgerichte leerweg & $\begin{array}{c}-0.093^{* * *} \\
(0.008)\end{array}$ & $\begin{array}{c}-0.093 * * * \\
(0.008)\end{array}$ & $\begin{array}{l}-0.016 \\
(0.012)\end{array}$ & $\begin{array}{l}-0.015 \\
(0.012)\end{array}$ \\
\hline Educational sector in pre- & & & & \\
\hline Percentage of students in & $\begin{array}{c}-0.044 * * \\
(0.017)\end{array}$ & $\begin{array}{c}-0.044 * * \\
(0.017)\end{array}$ & $\begin{array}{c}0.035 \\
(0.022)\end{array}$ & $\begin{array}{c}0.034 \\
(0.022)\end{array}$ \\
\hline Percentage of students in & $\begin{array}{c}-0.145^{* * *} \\
(0.013)\end{array}$ & $\begin{array}{c}-0.146 * * * \\
(0.013)\end{array}$ & $\begin{array}{c}-0.081 * * * \\
(0.025)\end{array}$ & $\begin{array}{c}-0.080 * * * \\
(0.025)\end{array}$ \\
\hline Percentage of students in & $\begin{array}{c}0.041 * * * \\
(0.015)\end{array}$ & $\begin{array}{c}0.040^{* * *} \\
(0.015)\end{array}$ & $\begin{array}{l}0.003 \\
(0.023)\end{array}$ & $\begin{array}{c}0.007 \\
(0.022)\end{array}$ \\
\hline Percentage of students in & $\begin{array}{c}-0.126^{* * *} \\
(0.048)\end{array}$ & $\begin{array}{c}-0.122 * * \\
(0.048)\end{array}$ & $\begin{array}{c}-0.133 * * \\
(0.058)\end{array}$ & $\begin{array}{c}-0.138^{* *} \\
(0.058)\end{array}$ \\
\hline Percentage of students in & $\begin{array}{l}-0.021 \\
(0.017)\end{array}$ & $\begin{array}{l}-0.022 \\
(0.017)\end{array}$ & $\begin{array}{c}0.007 \\
(0.025)\end{array}$ & $\begin{array}{c}0.007 \\
(0.025)\end{array}$ \\
\hline $\begin{array}{l}\text { Migrant background } \\
\text { Suriname }\end{array}$ & & & $\begin{array}{l}-0.050 \\
(0.060)\end{array}$ & $\begin{array}{l}-0.049 \\
(0.060)\end{array}$ \\
\hline Aruba & & & $\begin{array}{l}-0.022 \\
(0.061)\end{array}$ & $\begin{array}{l}-0.019 \\
(0.060)\end{array}$ \\
\hline Turkey & & & $\begin{array}{l}-0.052 \\
(0.061) \\
\end{array}$ & $\begin{array}{l}-0.050 \\
(0.060) \\
\end{array}$ \\
\hline
\end{tabular}




\section{Table 4.4 (continued)}

\section{Morocco}

Non western immigrant

Western immigrant

Second generation

Number of clusters

Observations

$\mathrm{R}^{2}$

126,048
-0.000

0.000

$\begin{array}{lrr}\mathrm{R}^{2} & 0.000 & 0.230\end{array}$ $\mathrm{p}<0.10, * * \mathrm{p}<0.05, * * * \mathrm{p}<0.01$ 




\title{
Chapter 5
}

\author{
Study Choice Regret among Vocational Education \\ Graduates: The Role of Unanticipated Labour Market \\ Conditions $^{35,36}$
}

\footnotetext{
35 This study is based on: Somers, M. A., \& Fouarge, D. (2019). Study choice regret among vocational education graduates: The role of unanticipated labour market conditions. Maastricht University (mimeo).

36 This study benefitted from discussions with participants of the ROA Conference on Human Capital over the Life Cycle, participants of the XXV Meeting of the Economics of Education Association, participants of the Eighth International Workshop on Applied Economics of Education, participants of the $4^{\text {th }}$ LEER Conference on Education Economics, participants of the $15^{\text {th }}$ Belgian Day for Labour Economists, participants of the $32^{\text {nd }}$ annual conference of the European Society for Population Economics, participants of the 30th European Association for Labour Economists, and participants of the Graduate School of Business and Economics Seminar on Learning and Work.
} 
Chapter 5

\begin{abstract}
Almost one in four Dutch graduates indicate shortly after graduation that they would have chosen a different field-of-study. Even when one has a job, regret about the field-ofstudy choice can reduce job satisfaction, productivity and wages. The analyses in this study rely on the assumption that youngsters choose a field-of-study partly based on expectations about future field-specific returns to education. We examine how the discrepancy between labour market conditions at the time that the course of study is chosen and actual labour market conditions upon labour market entry relates to regret in the field-of-study choice. Using data for Dutch secondary vocational graduates, we show that regret among male graduates is positively and significantly related to unfavourable changes in labour market conditions: a field-specific unemployment rate when choosing the study programme that is 1 percentage point higher than the unemployment rate upon entry into the labour market is associated with a 0.1 percentage points greater likelihood of reporting regret. For females, we do not find such a relation. From a policy perspective, our findings suggest that mid-term labour market forecasts by field-of-study provide relevant information that could potentially improve educational choices.
\end{abstract}




\section{$5.1 \quad$ Introduction}

Educational choices are typically made under a considerable amount of uncertainty regarding one's ability to complete the educational path chosen, field-specific returns to education, and the match between individual preferences and occupational characteristics (Altonji, Arcidiacono, \& Maurel, 2016; Fouarge, Kriechel \& Dohmen, 2014; Holland et al., 1980; Siow, 1984; Weiss, 1971; Wiswall \& Zafar, 2015a; Zarkin, 1985). Consequently, many students struggle to make adequate educational choices. In fact, decisions concerning educational choices are among the most common regrets experienced in life (Roese \& Summerville, 2005). Almost a quarter of Dutch vocational education graduates indicate after completion of their studies to regret their schooling choices and that they rather would have chosen a different field-of-study (ROA, 2017b). Conditional on regret, for those individuals who decide to switch between fields of study, the increase in study time devoted to correct initial investments will result in costs to the individual (e.g. increased study costs and foregone earnings due to longer study duration), but also in a significant loss of productive capacity to the economy. Borghans and Golsteyn (2006) estimated the capacity loss caused by study delays to be 5.7 billion euros per year in the Netherlands. Hence, increasing our understanding of factors that affect optimal study choices is of direct interest to individuals, firms and policy makers.

This study investigates how unanticipated changes in labour market conditions relate to the quality of choices as measured by whether graduates experience regret of the chosen field-of-study. Human capital theory predicts that agents make schooling choices that maximize their utility (Becker, 1994; Mincer, 1974). This theory relies on the assumption that individuals base their schooling investment decision on expectations about their ability to successfully complete the chosen study programme (Arcidiacono, Hotz \& Kang, 2012, Zafar, 2013), and return expectations (Wiswall, \& Zafar, 2015a). However, studies show that youngsters' perceptions with respect to the cognitive demands of a specific study programme are often not realistic (Bettinger, \& Long, 2009; Pistolesi, 2017). Related to the focus of this chapter, there is also evidence that youngsters' earnings expectations are noisy (Jensen, 2010), such that expected labour market outcomes may not match realized earnings paths upon graduation. However, evidence also suggests that youngsters are responsive to feedback containing labour market information on returns to education, and revise expectations and their choices when presented with such information (Jensen, 2010, Oreopoulos \& Dunn, 2013).

This study uses a rich dataset based on the Dutch school leaver survey conducted by the Research Centre for Education and the Labour Market (ROA). Although the data cover graduates in all fields and at all levels of the Dutch education system, our analyses focus 


\section{Chapter 5}

on a homogeneous group of recent graduates in terms of the attained level of education: graduates from senior secondary vocational education (in Dutch: middelbaar beroepsonderwijs), who are surveyed 1.5 years after graduation. ${ }^{37}$ Secondary vocational education in the Netherlands is strongly oriented toward specific professions and is therefore characterized by a strong education-labour market linkage. Furthermore, a large share of secondary vocational education graduates enters the labour market upon graduation. ${ }^{38}$ Unexpected changes in the economy are thus more relevant for these graduates than for graduates from the broader academic track. The analyses are based on data for 30,690 graduates covering the time frame 2002-2014. The survey data includes information on graduates' attended level as well as field-of-study, the transition between education and the labour market, the current occupation, and a measure for regret of the study choice: whether or not graduates would choose the same field-of-study if they had to choose again (Borghans \& Golsteyn, 2007). In our data, about 23 percent of the females report regret of their field-of-study choice against 22 percent among males. We perform our analyses for males and females separately for two reasons. First, fields of study in vocational education are gender specific. At the highest level of vocational education, level 4, only 31 percent of females graduate from technical fields against 83 percent in the field Culture and Society (ROA, 2017b). Second, males and females have different expectations about future earnings (Reuben, Wiswall, \& Zafar, 2017), and they care about different things when making their education choice (Gemici, \& Wiswall, 2014). For example, males care more about pecuniary aspects of their future job than do females (Zafar, 2013).

Although we do not directly measure students' expectations and their exposure to information about current and expected returns to education, it is likely that students from a particular cohort base their choices on what they know about labour market outcomes by field-of-study. Potential sources of information include knowledge from parents, family and peers (Xia, 2016), study counsellors (Borghans, Golsteyn \& Stenberg, 2015), information published in the media and dedicated websites (Vrontis, Thrassou \& Melanthiou, 2007). In the absence of information on expected future returns to education, youngsters will derive information from realisations of previous cohorts of graduates; their employment probability, their wage, and the probability of finding a job that matches the attended level and field-of-study. Our operationalisation of unanticipated

\footnotetext{
${ }^{37}$ In the remainder of this chapter, we will refer to senior secondary vocational education as secondary vocational education.

38 Between 2008 and 2013, 58 percent of the secondary vocational education graduates who participated in the ROA school leaver survey entered the labour market upon graduation (ROA, 2016). This percentage represents the graduates who attended a school-based vocational track. This group is also the focus of our analyses.
} 
changes in labour market conditions is based on the field-of-study specific difference between actual unemployment at time of labour market entry and the observed unemployment rate at the time of study choice.

In the Netherlands, there is growing attention for the development of relevant indicators of current and future field-specific labour demand to assist prospective students in the choice of education and occupation. For (prospective) students in secondary vocational education, the Cooperation Organisation for Vocational Education, Training and the Labour Market (S-BB; www.s-bb.nl) has the task to provide information about current practice placements and apprenticeships. Since 2016, S-BB also publishes indicators for the future demand by study programme. Finally, a commercial platform (www.keuzegids.org) yearly offers current and forecast information by field-of-study at the secondary vocational education level. An open question is whether the increasing availability of forecast information can be expected to affect youngsters' field-of-study choice. Although we cannot test this directly, we can test whether unexpected changes in labour market conditions affect youngsters' regret for the chosen field. If such is the case, labour market forecasts by field-of-study would be of added value. However, because we do not observe students' actual expectations, our study provides lower bound estimates of how unanticipated changes in labour market conditions relate to regret of the chosen field-of-study among graduates.

Our contribution to the literature is threefold. To the best of our knowledge, Borghans and Golsteyn (2005) is the only other study that examined the relation between labour market conditions and regret of the chosen field-of-study. ${ }^{39}$ Using data from recent Dutch graduates for the time period 1995-2003, the authors found that an increase of 1 percentage point in the unemployment rate is related to an increase of 2.1 percentage points in the share of graduates reporting regret of the chosen field-of-study. ${ }^{40}$ Our first contribution is to replicate their study using a longer time frame that covers multiple economic cycles with rising and declining youth unemployment. Moreover, in contrast to Borghans and Golsteyn (2005), our study accounts for individuals' success in the labour market and specifically focuses on graduates from secondary vocational education.

\footnotetext{
39 Other studies focus on business cycle earnings variation and expected earnings (e.g. Beffy, Fougère \& Maurel, 2012) or business cycle employment variation and enrolment rates (e.g. Bardhan, Hicks \& Jaffee, 2013).

40 Bardhan et al. (2013) showed that students respond more strongly to changes in employment prospects than to changes in wages, suggesting that students attach more value to employment opportunities than to earnings. Graduates from Dutch vocational education also appear to care more about employment opportunities of the chosen field-of-study, than about the wage (Fouarge, de Koning, \& Künn-Nelen, 2018). Therefore, in this study we focus on changes in labour market conditions as a determinant for regret and not on changes in earnings.
} 


\section{Chapter 5}

Our second contribution is to explore whether regret of the chosen field-of-study operates in a symmetrical manner in the context of 'better-than-' and 'worse-than-' expected labour market situations. Prior research on regret has shown that individuals assign more weight to worse-than-expected outcomes than to better-than-expected outcomes (Landman, 1987; Tversky \& Kahneman, 1974). Our third contribution is to document heterogeneity by gender as literature suggests that males and females choose differently (Gemici \& Wiswall, 2014; Reuben et al., 2017).

\subsection{How do outcomes lead to regret?}

\subsubsection{Defining regret of the study choice}

Regret is defined as a negative emotion that is experienced when an individual realizes that the outcome or utility of a certain decision would have been better if an alternative had been chosen (Bell, 1982; Zeelenberg, 1999). Although the outcome of an alternative is not always observed, the experience of regret is not limited to situations in which the outcomes of alternatives are known. The study on counterfactual thinking postulates that regret is generated from people's imagined alternatives (Kahneman \& Miller, 1986). Even if graduates do not observe the actual labour market outcomes of non-chosen alternative schooling paths, regret of the chosen field-of-study could be generated by the perceived outcome of alternatives.

This study is concerned with experiencing regret in the short run, namely, 1.5 years after graduation. Two advantages arise from eliciting graduates' perception of regret in a shortrun evaluation. First, asking about young individuals' regret shortly after graduation involves a feeling of discomfort at a time when it is still possible to rectify human capital investments. Hence, regret will endure while the possibility to change remains high (Roese, \& Summerville, 2005). This approach provides a good estimate of how pervasive regret is among young school-leavers who are the best candidates to provide insight into the need for improving study choices. Second, as younger workers are relatively sensitive to changes in labour market conditions, their regret is more likely to depend on labour market conditions upon labour market entry than at a later career stage (Verick, 2009). In other words, the experience of regret among young graduates is less likely to have been influenced by other career choices and experiences given their short career.

\subsubsection{Expectations, realisations, and regret}

According to economic theory, an individual chooses a set of actions as to maximize the value of decision outcomes (Heap et al., 1992). Rational choice theory posits that individuals are fully informed, have a stable set of preferences and the ability to calculate, for each alternative course of action, which of these generates the highest utility (Simon, 
1955; Siow, 1984; Zarkin, 1985). By assuming that the choice maker is fully informed, has the ability to compute with perfect accuracy, and is fully rational, little room is left for expecting that individuals make decisions that lead to unforeseen events.

Although youngsters tend to make rational schooling choices based on a cost-benefit consideration (Kaufmann, 2014), individuals do not always act as if they were maximizing expected utility. The cognitive demands placed on the individual are often too great in order to be consistent with the rational choice theory (Simon, 1955). Individuals often turn to mental shortcuts in order to guide their decisions (Tversky \& Kahneman, 1974). Moreover, information problems can prevent individuals from behaving in an optimal way. In the case of educational choices, information deficiencies may pertain to individual preferences towards occupations and various future labour market outcomes (Borghans, De Grip \& Heijke, 1996; Siow, 1984; Zarkin, 1985). As empirical evidence points out, college students' wage expectations do not always correspond well to actual wages (Betts, 1996; Brunello, Lucifora \& Winter-Ebmer, 2001; Carvajal et al., 2000; Conlon, 2017; Diaz-Serrano \& Nilsson, 2017). Given that educational paths take several years to be completed, students are required to shape their expectations about the complicated and non-transparent job market. Although Webbink and Hartog (2004) found that college students' expectations of their future earnings correspond quite well to their realized starting salaries, other studies indicate that the ability to predict future earnings is not homogeneous across the student population (Betts, 1996; Botelho \& Costa Pinto, 2004; Brunello et al., 2001; Carvajal et al., 2000).

For example, vocational education students appear to make prediction errors because they do not allow for variation between present labour market signals and future labour market conditions (Borghans et al., 1996). In the absence of labour market forecasts, it is not obvious how available information should be interpreted to anticipate future labour market outcomes as the labour market is very complex (Freeman, 1971). Due to the inability to make adequate forecasts, students in vocational education will form their wage expectations based on the wages that can directly be observed, namely, the current wages (Borghans et al., 1996). The average starting salary of graduates with a specific degree can be considered a suitable indicator of the labour market situation that will be faced upon labour market entry as most wages are determined by collective bargaining agreements in the Netherlands. However, this is likely to be an imperfect indicator. Deviations in the context under which students made their initial schooling choices, such as a shift in the field-specific labour demand, can cause a discrepancy between the expected and realized labour market outcomes. Even if detailed labour market forecasts by field-of-study are available, students might not incorporate the available information in their decision making process. As a consequence, graduates may realize upon graduation that an 


\section{Chapter 5}

alternative educational path would have been superior, which in turn can lead graduates to experience regret (Loomes \& Sugden, 1987). Hence, the larger the difference between actual labour market conditions at labour market entry, and the expectations when making the field-of-study choice, the larger will the experienced regret be (Borghans et al., 1996). This leads us to the first hypothesis:

H1: Regret of the chosen field-of-study is positively associated with the discrepancy between actual labour market conditions upon labour market entry and expected labour market conditions when the field-ofstudy choice was made.

However, as discussed in the introduction, males and females form different expectations about the future labour market and value specific labour market outcomes differently (Gemici \& Wiswall, 2014; Reuben et al., 2017). As an extension, therefore, we examine the relation between changes in labour market conditions and regret of the chosen fieldof-study for male and females separately. In particular, because females put less weight on pecuniary labour market outcomes (Zafar, 2013), we expect that:

H2: Females are less inclined than males to regret the field-of-study choice when realizations do not meet expectations.

Although unanticipated changes in labour market conditions are expected to influence regret, this relation might only hold for individuals whose own realized labour market outcomes negatively differ from the predicted outcomes. In this study, four labour market outcomes are considered, namely, finding a job, and conditional on being employed; the realized wage, being in a job that matches the attended field-of-study, and being in a job that matches the acquired level of education. First, graduates are more likely to bemoan their study choices if the actual probability of getting a job is lower than expected. Being unemployed shortly after graduation is likely to reflect a negative deviation from the expected probability of finding a job. Second, taking $w^{r}$ to represent the realized wage upon labour market entry and $\bar{w}^{e}$ to represent the expected wage when the study choice is made, an individual will experience regret when $w^{r}<\bar{w}^{e}$. Therefore, receiving an income that is lower than the expected wage given the field-of-study can be considered a deviation from the wage that students predicted based upon past information. Third, students are expected to select a field-of-study with the expectation of finding employment in a related occupation (Betts, 1996). As shown in Chapter 2, ending up in an occupation that is unrelated to the field-of-study (horizontal mismatch) can lead to an underutilization of skills and result in job dissatisfaction. This also holds when the individual acquired an educational level that is higher than required for the job, also referred to as vertical mismatch (Mora, 2010; Sicherman, 1991). In fact, university graduates are more likely to experience regret when they are vertically or horizontally 
mismatched (Kucel \& Vilalta-Bufí, 2013; Mora, 2010). One can therefore expect the effect of labour market conditions on regret to be weaker when a workers' job matches the field as well as level of education. The expectation formulated under H1 is only expected to hold if the individual actually faces unanticipated labour market outcomes in light of the changed labour market conditions. The third hypothesis concerning the relation between regret and changes in labour market conditions is therefore formulated as follows:

H3: The relationship between labour market conditions and regret is driven by graduates' actual labour market success.

Finally, we examine to what extent the mismatch between expectations about the future labour outcomes and actual realisations has a symmetric impact on regret. Depending on employers' demand for graduates from specific fields, actual labour market outcomes could turn positive while one had poor expectations, and vice versa. Insights from cognitive psychology and behavioural economics suggest that, on average, individuals are risk averse (Tversky \& Kahneman, 1974) and value poorer outcomes than expected more negatively than they would positively value better outcomes than expected. Prior research on regret showed that individuals assign more weight to worse-than-expected labour market conditions than to better-than-expected conditions (Landman, 1987). Therefore, we assess whether worse-than-expected labour market conditions (better than-expected labour market conditions) increases (decreases) the likelihood that graduates experience regret. We expect that especially labour market realizations that are poorer than expected result in regret. Our fourth hypothesis is, therefore, formulated as follows:

H4: The relationship between labour market conditions and regret is stronger when labour market conditions are worse than expected than when labour market conditions are better than expected.

\subsection{Data and descriptive statistics}

The empirical analyses are based on time series data from the ROA school leaver survey covering the years 2002-2014. The survey serves as a monitoring instrument with the primary aim of increasing the understanding of the transition from school to work. In those years, respondents were interviewed by means of a postal survey, 1.5 years after graduation and were asked about their attended level and field-of-study, subsequent study activities, and labour market outcomes. While the data cover and are representative for the full breadth of the Dutch education system, our analyses focus on graduates from secondary vocational education for two reasons. First, a large share of secondary vocational education students enters the labour market upon graduation (ROA, 2017b). Second, the connection between the field-of-study choice and subsequent occupational 


\section{Chapter 5}

sorting is stronger for these graduates than for graduates from the academic track. Hence, changes in labour market conditions are more directly relevant for graduates from the vocational track than for graduates from the broader academic track.

In the Netherlands, students typically enter secondary vocational education at the age of 16 upon completion of preparatory secondary vocational education (in Dutch: voorbereidend middelbaar beroepsonderwijs). In the schoolyear 2016-17, secondary vocational education encompassed 41 percent of the students who were either in secondary vocational education or higher education (www.onderwijsincijfers.nl). The duration of study programmes within secondary vocational education varies between 6 months and 4 years, depending on the level of study. The secondary vocational education system consists of four levels; level 1 is the lowest, 4 is the highest. Level 1 takes 6 months to 1 year to be completed, level 2 takes 1 to 2 years, level 3 takes 2 to 3 years, and the duration of level 4 is 3 to 4 years. A level 2, 3 or 4 degree is considered a labour market qualification. Students are allowed to enter university of applied science with a level 4 degree. The Dutch secondary vocational education system offers a school-based pathway as well as a work-based pathway and students can attend school part-time or fulltime. In the schoolyear 2016-17, roughly 80 percent of the students attended the schoolbased pathway (www.onderwijsincijfers.nl). Work-based learning forms a key aspect in both pathways.

Graduates in the survey were either enrolled in subsequent education (typically at a higher level) or active in the labour market. The analyses are restricted to individuals who entered the labour market upon graduation. Additionally, the study excludes graduates who attended part-time education or who followed the work-based vocational track. Given that these graduates are often already employed before graduation, they are less likely to be affected by changes in labour market conditions. Because a level 1 degree is not a labour market qualification, and a large share of these graduates re-enrol in education at a higher level, the analyse are restricted to graduates with at least a level 2, 3 or 4 diploma. After these restrictions, the sample includes 37,735 school-leavers. These school-leavers attended full-time education, obtained a school-based vocational (level 2, 3 or 4) diploma between 2002 and 2014, and entered the labour market either in a job or as a job seeker. After removing cases with missing variables, we trim the bottom and top one percent of the wage distribution to limit the influence of wage outliers. The final sample comprises 30,690 observations.

To test our hypotheses, information on key variables of the research framework were measured by predetermined items in the ROA school leaver survey. Most constructed 
items were either extracted from validated academic measurement scales or by investigating items used in prior academic research.

Regret We use the same indicator for regret as Borghans and Golsteyn (2007). Regret was measured by the following question: 'Looking back, if you were free to choose again, would you choose the same study programme?'. Respondents could answer this question with: 1) yes, the same education and at the same institution, 2) yes, the same education, but at a different institution, 3) no, a different education, namely: ..., 4) no, an education on another level, 5) no, I would not continue studying. Consequently, the initial answers were recoded into a binary variable, taking the value ' 0 ' if the answer was yes and ' 1 ' if the answer was no.

Labour market conditions and expectations We assume that students' field-of-study choice is in part based on expectations they have about the future labour market (Borghans et al., 1996). Although we do not observe these expectations directly, we assume that students from a particular cohort could base their choices on what they know about labour market outcomes by field-of-study from prior cohorts that graduated at the time they made their education choice. As the largest share of Dutch students indicate to choose a field-ofstudy within the year before they enrol in the study programme (Borghans \& Golsteyn, 2005), we expect students to gather information about the labour market outcomes for specific fields of study (e.g. field-specific likelihood of unemployment) in the year before enrolment. As a measure of unemployment expectations $\left(\mathrm{U}_{\text {ef }}\right)$, we therefore calculate the unemployment rate of graduates with the same field $(f)$ and level $(\zeta$ of study who have entered the labour market at the time the youngsters in our survey were actually making their own schooling choice. ${ }^{41}$ Let $t$ be the time in which graduates participate in the survey. Graduates are assumed to have gathered information about the current unemployment rate in $t-d$. Where, $d$ is the length of the study programme plus 1.5 years (the time between the end of the study programme and survey) plus 1 year (since most youngsters choose a field in the year before they enrol). For example, if a school-leaver is surveyed in 2006 and has attended level 4 of secondary vocational education (which takes on average 3.5 years to be completed), this graduate is expected to have enrolled his/her study programme in 2001 and to have chosen the field-of-study in the year prior to enrolment, namely, in 2000. The estimation of these graduates' expectations of future labour market conditions is then based on the share of unemployed graduates with the

\footnotetext{
41 The fields of study were classified according to the International Standard Classification of Education (ISCED 1997). We distinguish between eight fields: (1) Education, (2) Humanities and Arts, (3) Social Sciences, Business and Law, (3) Science, Mathematics and Computing, (4) Engineering, Manufacturing, and Construction, (5) Agriculture and Veterinary, (6) Health and Welfare, and (7) Services. The following question was used to measure the employment status: 'At the moment, do you have paid employment?', which could be answered by 'yes' and 'no'.
} 
same field and level of study who participate in the survey in 2000. The difference between the unemployment rate actually faced upon labour market entry $\left(\mathrm{U}_{a f l}\right)$ and the expected unemployment rate when the field-of-study is chosen $\left(\mathrm{U}_{\text {efl }}\right)$ is taken as an indicator of how much the actual labour market conditions deviate from what was expected. ${ }^{42}$ When regressed on regret to test $H 1$, this indicator reveals the extent to which unanticipated changes in labour market outcomes by field-of-study influence the quality of study choices. Given that available information sources in the Netherlands do not provide unemployment risk indicators that are gender specific, we assume that male and females do not gather gender specific information when making their field-of-study choice. $^{43}$

Individuals' success in the labour market Of course, experiencing regret could depend more strongly on one's own labour market success than on the average success rate of one's cohort of graduates, as we hypothesise under H3. To assess an individual's success in the labour market, we consider whether an individual is employed or not at the time of the survey. Furthermore, conditional on being employed, we also take into account the quality of the match in terms of earnings as well as the horizontal and vertical match between graduates' job and their education. With respect to earnings, we take the logarithm of graduates' self-reported monthly gross earnings, corrected for inflation (i.e. real earnings). To measure whether the type of education is appropriate for graduates' job, the following question was asked: 'Which field-of-study was required for your job?'. The question could be answered by: (1) Exclusively the field I attended, (2) The field I attended or a related field, (3) A completely different field, or (4) No specific field. The initial items were recoded into a ' 0 ' when respondents choose 1 or 2 , implying that the graduate is horizontally matched, and items 3 and 4 were recoded into a ' 1 ', indicating that the graduate is horizontally mismatched. To measure vertical mismatch, respondents were asked which level of education was minimally required for their job. A dummy variable was created where graduates who work at a level below their obtained level of education were coded into a ' 1 ', whereas graduates who have a job that required at least their obtained level of education received a ' 0 '.

42 The field-specific unemployment rate is calculated by dividing the number of unemployed graduates by the total number of graduates in a specific level and field of education in a specific survey year. The total number of graduates and the number of unemployed graduates have been weighted in order to obtain estimates that are representative for the population.

43 We also conducted our analyses using the difference between the non-gender specific unemployment rate at the time of field-of-study choice and the gender specific unemployment rate at the time of labour market entry as the main explanatory variable. The results can be found in Appendix 5.1. The coefficients are not statistically different from the coefficients that are obtained when the non-gender specific unemployment rate at the time of labour market entry is used. In addition, in some of our analyses, we control for the actual labour market outcomes of the individuals in our data. 
Control variables As control variables, several background characteristics are included in the analyses. Our analyses account for respondents' age as prior research has shown age is related to respondents' emotional responsiveness in self-reports (Carstensen et al., 2000; Chevalier, 2002; Fischer, 2000; Scherer, Wallbot \& Summerfield, 1986). Moreover, we control for graduates' attended field-of-study by including a set of dummies. We do this because the image that youngsters form of a field-of-study does not always match reality (Borghans \& Golsteyn, 2005). For instance, graduates with a too positive image of their field-of-study are more likely to experience regret of the chosen field. We also control for the level of education as regret is more likely to be experienced among lower-educated graduates (Borghans \& Golsteyn, 2005). Finally, graduates' ability positively influences educational as well as labour market outcomes (Wise, 1975). Moreover, graduates with higher cognitive skills make more adequate choices and may consequently be less likely to experience regret. We proxy ability by a graduate's grade point average (GPA) which is self-reported on the following scale: $6,6.5,7,7.5,8$, and 8.5 or higher.

Table 5.1 and 5.2 summarise the descriptive statistics for male and female graduates respectively. ${ }^{44}$ The variables indicating the discrepancy between the realized and expected wage and the match between graduates' job and the attended field and level of education are only available for graduates who are employed 1.5 years after graduation. The number of observations for these variables is therefore lower than for the other variables. Of the final sample, approximately 22 percent of the male and 23 percent of the female graduates report regret. With respect to the explanatory variable of interest (measured in percentage points), the difference between the expected unemployment rate and the actual unemployment rate upon labour market entry is 2.7 percentage points on average for males and 2.4 percentage points for females. The average age of the graduates in our sample is 22.3 years for males and 22.6 years for females. Table 5.1 and 5.2 show that fields of study in secondary vocational education are very gender specific. While the majority of male graduates have attended an 'engineering, manufacturing and construction' related field, the majority of females in our sample graduated in a 'health and welfare' related field-of-study. The majority of male as well as female graduates have obtained a degree from the fourth level of secondary vocational education.

Regarding the labour market outcomes, 8.3 percent of the male graduates who entered the labour market are unemployed 1.5 years after graduation as opposed to 8.8 percent of the female graduates. The average real gross monthly wage for males is close to 1473 euro 1.5 years after graduation, while for female graduates, the realized gross monthly wage is

\footnotetext{
44 These descriptive statistics are weighted. In our sample, 35 percent of the respondents are male and 65 percent of the respondents are female. In the period 2002-2014, the population attending the fulltime school-based pathway consisted for 48 percent of males and 52 percent of females (CBS, 2018).
} 


\section{Chapter 5}

approximately 1245 euro. While roughly 32 percent of our male sample is horizontally mismatched, 29 percent is vertically mismatched. Finally, 27 percent of our female sample is approximately horizontally mismatched and about 22 percent is vertically mismatched.

\section{Table 5.1: Summary statistics male sample}

\begin{tabular}{lccccc}
\hline \hline Variable & $\mathrm{N}$ & Mean & Std. Dev. & Min & Max \\
\hline Regret & 10,715 & 0.221 & 0.415 & 0 & 1 \\
Actual unemployment rate - & 10,715 & 2.730 & 8.34 & -78.95 & 49.50 \\
$\quad$ expected unemployment rate & & & & & \\
Age & 10,715 & 22.24 & 4.094 & 17 & 62 \\
GPA & 10,715 & 7.180 & 0.556 & 6 & 8.5 \\
Level of education & & & & & \\
$\quad$ Level 2 secondary vocational education & 10,715 & 0.262 & 0.440 & 0 & 1 \\
Level 3 secondary vocational education & 10,715 & 0.168 & 0.374 & 0 & 1 \\
Level 4 secondary vocational education & 10,715 & 0.570 & 0.495 & 0 & 1 \\
Field-of-study & & & & & \\
Education & 10,715 & 0.004 & 0.060 & 0 & 1 \\
Humanities and Arts & 10,715 & 0.041 & 0.198 & 0 & 1 \\
Social Sciences, Business and Law & 10,715 & 0.199 & 0.399 & 0 & 1 \\
Science, Mathematics and Computing & 10,715 & 0.085 & 0.278 & 0 & 1 \\
Engineering, Manufacturing and Construction & 10,715 & 0.308 & 0.462 & 0 & 1 \\
Agriculture and Veterinary & 10,715 & 0.075 & 0.263 & 0 & 1 \\
$\quad$ Health and Welfare & 10,715 & 0.067 & 0.250 & 0 & 1 \\
Services & 10,715 & 0.222 & 0.416 & 0 & 1 \\
Employment status (1 = unemployed) & 10,715 & 0.083 & 0.275 & 0 & 1 \\
Variables for employed graduates & & & & & \\
Wage & 8,619 & 1472.94 & 539.84 & 175.74 & 2877.525 \\
Horizontal mismatch (1 = horizontally mismatched) & 8,619 & 0.322 & 0.467 & 0 & 1 \\
Vertical mismatch (1 = vertically mismatched) & 8,619 & 0.285 & 0.452 & 0 & 1 \\
\hline \hline
\end{tabular}


Table 5.2: Summary statistics female sample

\begin{tabular}{lccccc}
\hline \hline Variable & N & Mean & Std. Dev. & Min & Max \\
\hline Regret & 19,975 & 0.228 & 0.420 & 0 & 1 \\
Actual unemployment rate - & 19,975 & 2.389 & 6.364 & -78.95 & 100 \\
$\quad$ expected unemployment rate & & & & & \\
Age & 19,975 & 22.557 & 5.200 & 16 & 61 \\
GPA & 19,975 & 7.349 & 0.534 & 6 & 8.5 \\
Level of education & & & & 0 & 1 \\
$\quad$ Level 2 secondary vocational education & 19,975 & 0.166 & 0.372 & 0 & 1 \\
Level 3 secondary vocational education & 19,975 & 0.301 & 0.459 & 0 & 1 \\
Level 4 secondary vocational education & 19,975 & 0.532 & 0.499 & 0 & 1 \\
Field-of-study & & & & 0 & 1 \\
Education & 19,975 & 0.018 & 0.131 & & \\
Humanities and Arts & 19,975 & 0.025 & 0.156 & 0 & 1 \\
Social Sciences, Business and Law & 19,975 & 0.214 & 0.410 & 0 & 1 \\
Science, Mathematics and Computing & 19,975 & 0.003 & 0.055 & 0 & 1 \\
Engineering, Manufacturing and Construction & 19,975 & 0.026 & 0.159 & 0 & 1 \\
Agriculture and Veterinary & 19,975 & 0.039 & 0.193 & 0 & 1 \\
Health and Welfare & 19,975 & 0.507 & 0.500 & 0 & 1 \\
$\quad$ Services & 19,975 & 0.168 & 0.374 & 0 & 1 \\
Employment status (1 = unemployed) & 19,975 & 0.088 & 0.283 & 0 & 1 \\
Variables for employed graduates & & & & & \\
Wage & 15,807 & 1245.09 & 486.00 & 172.65 & 2877.53 \\
Horizontal mismatch (1 = horizontally mismatched) & 15,807 & 0.271 & 0.444 & 0 & 1 \\
Vertical mismatch (1 = vertically mismatched) & 15,807 & 0.223 & 0.416 & 0 & 1 \\
\hline \hline
\end{tabular}

\subsection{Empirical strategy}

To analyse the relationship between regret and changes in labour market conditions (H1), we estimate the following model:

$$
\mathrm{y}_{\mathrm{i}}=\alpha_{0}+\alpha_{1}\left(\mathrm{U}_{a f l}-\mathrm{U}_{e f l}\right)+\alpha_{2} \mathrm{X}_{\mathrm{i}}+\varepsilon_{\mathrm{i}}
$$

Here, $y_{i}$ equals 1 if individual $i \in\{1,2, \ldots, N\}$ reports regret and 0 otherwise. $U_{\text {afl }}$ represents the actual field $(f)$ and level $(l)$ specific unemployment rate that graduates face upon labour market entry, whereas $U_{\text {efl }}$ captures the expected unemployment rate in the year before enrolment in education. The main parameter of interest is $\alpha_{1}$. $\mathrm{U}_{a f l}-\mathrm{U}_{e f l}$ captures the extent to which changes in labour market conditions are correctly anticipated. It is positive when the employment rate at labour market entry is higher than expected, implying that the actual labour market conditions are worse than at the time the field-of-study choice is made. In the case that the unemployment rate upon labour market entry is lower than expected, $\mathrm{U}_{a f l}-\mathrm{U}_{\text {efl }}$ is negative. $\mathrm{X}_{\mathrm{i}}$ is a vector of individual characteristics: age, field-of-study, level of education, and GPA. The error term is denoted 


\section{Chapter 5}

by $\varepsilon_{\mathrm{i}}$. We estimate model 1 without (1a) and with control variables (1b). We postulate that individuals' own labour market success might be more important for the probability of experiencing regret than changes in unemployment rates per se $(H 3)$. To test for test this, we estimate a second model:

$$
y_{i}=\alpha_{0}^{\prime}+\alpha_{1}^{\prime}\left(U_{a f l}-U_{e f l}\right)+\alpha_{3} S_{i}+\alpha_{2}^{\prime} X_{i}+\varepsilon_{i}^{\prime}(2)
$$

where $S_{i}$ captures several indicators of individual success in the labour market; being employed or not, the logarithm of graduates' self-reported monthly gross earnings, being matched in terms of the field-of-study, and, being matched in terms of the required education level for the job. First, model 2 is estimated by adding an indicator for whether or not the graduate is employed to model $1 \mathrm{~b}$ (model 2a). Model $2 \mathrm{~b}$ excludes unemployed individuals and includes the remaining indicators for graduates' success in the labour market.

The models are estimated using a probit specification, and we report the marginal effects at the sample mean. All models cluster the standard errors at the level of the field-ofstudy, the level of education, and the year of participation (i.e. the level at which $\left(\mathrm{U}_{a f l}-\mathrm{U}_{\text {efl }}\right)$ is constructed). To test for gender differences (H2), we estimate equations (1) and (2) separately for male and female graduates. To test for asymmetry in the relation between unanticipated changes in the labour market and regret (H4), we estimate equations (1) and (2) using two split samples, one for which $\left(\mathrm{U}_{\text {afl }}>\mathrm{U}_{\text {efl }}\right.$ ), reflecting worse-than-expected labour market conditions, and one for which $\left(\mathrm{U}_{a f l}<\mathrm{U}_{e f l}\right)$, reflecting better-than-expected labour market conditions. ${ }^{45}$

\section{$5.5 \quad$ Results}

\subsubsection{Descriptive evidence}

Figure 5.1 depicts the development of regret for each level of secondary vocational education and the discrepancy between expected and actual labour market conditions upon labour market entry for the period 2002-2014 based on a weighted sample. The graphs are shown for males and females and each level of secondary vocational education separately. For the sake of presentation, the discrepancy between actual unemployment and expected unemployment $\left(\mathrm{U}_{a f l}-\mathrm{U}_{e f l}\right)$ is aggregated at the educational level. Each dot on the dashed lines indicates the average discrepancy between the actual and expected field and level specific unemployment rate in a specific year for a specific level of education.

\footnotetext{
45 All the regressions are estimated on unweighted samples as the covariates will account for graduates' characteristics that are also included in the survey weights.
} 
Figure 5.1: Discrepancy between expected and actual unemployment rate and regret

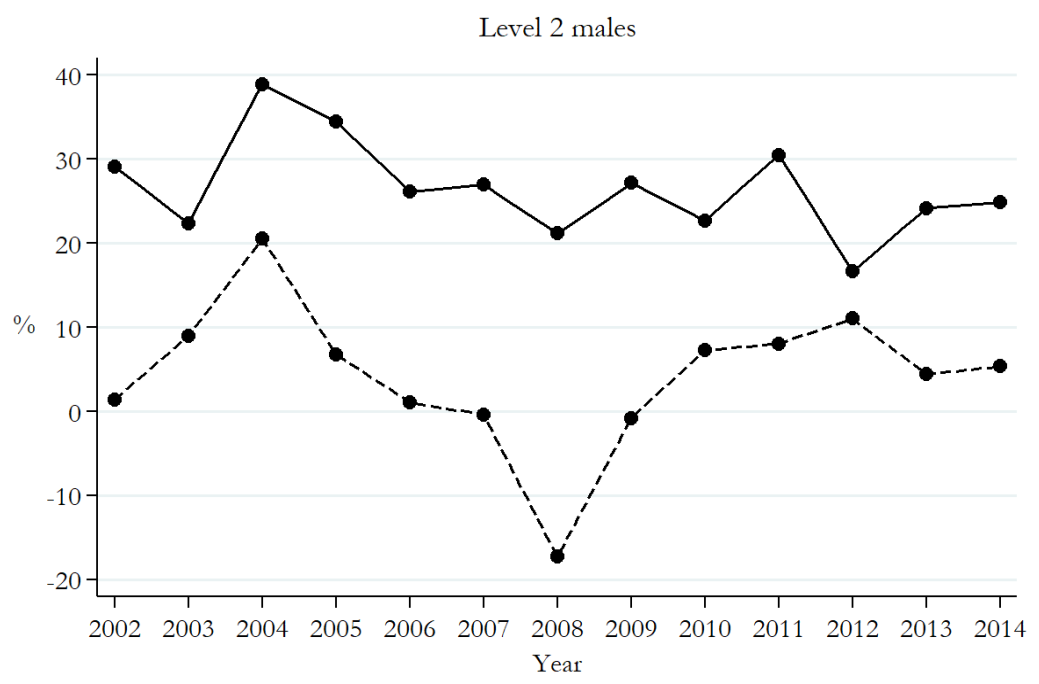

Level 3 males
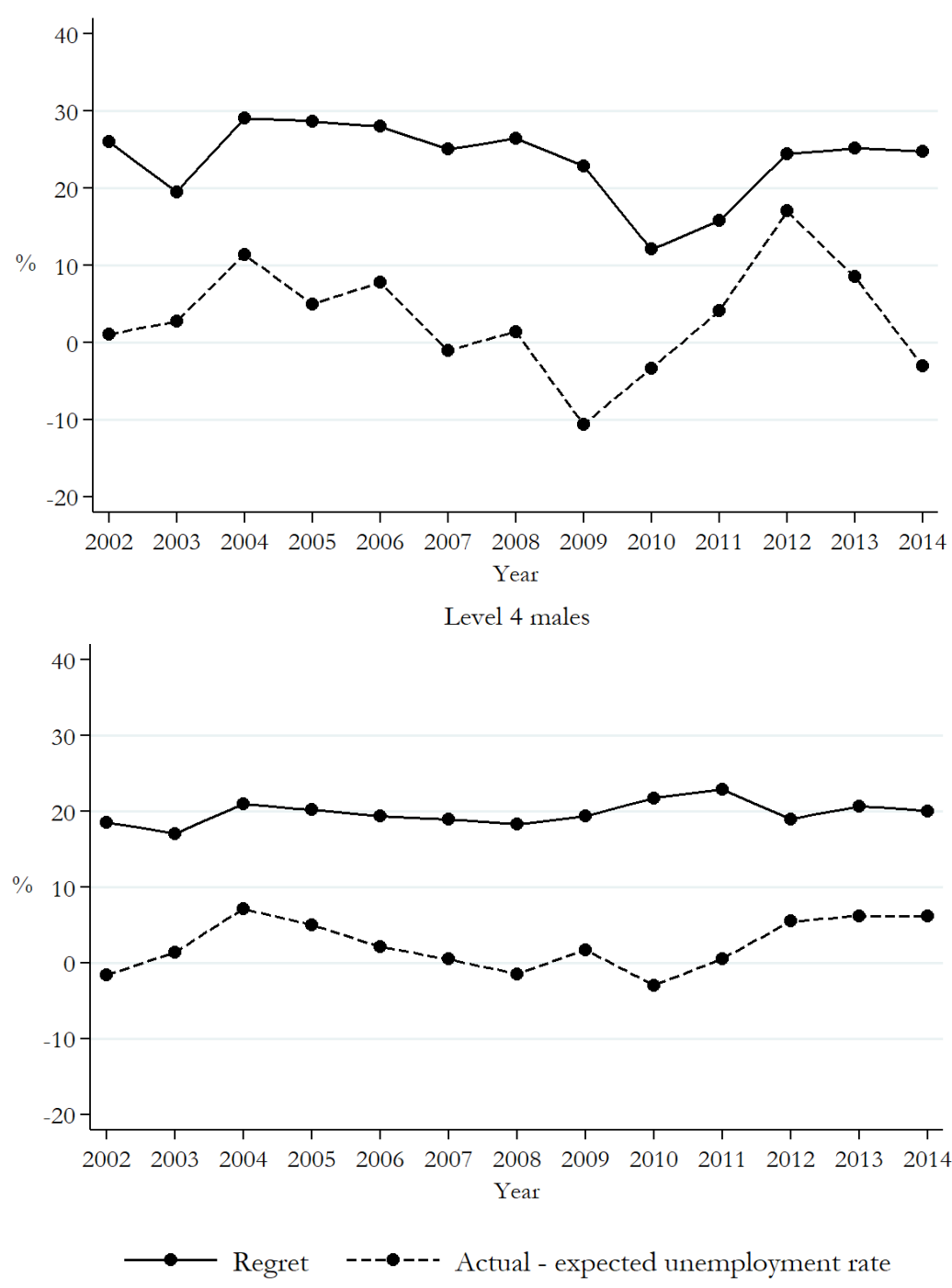
Chapter 5

Figure 5.1 (continued)

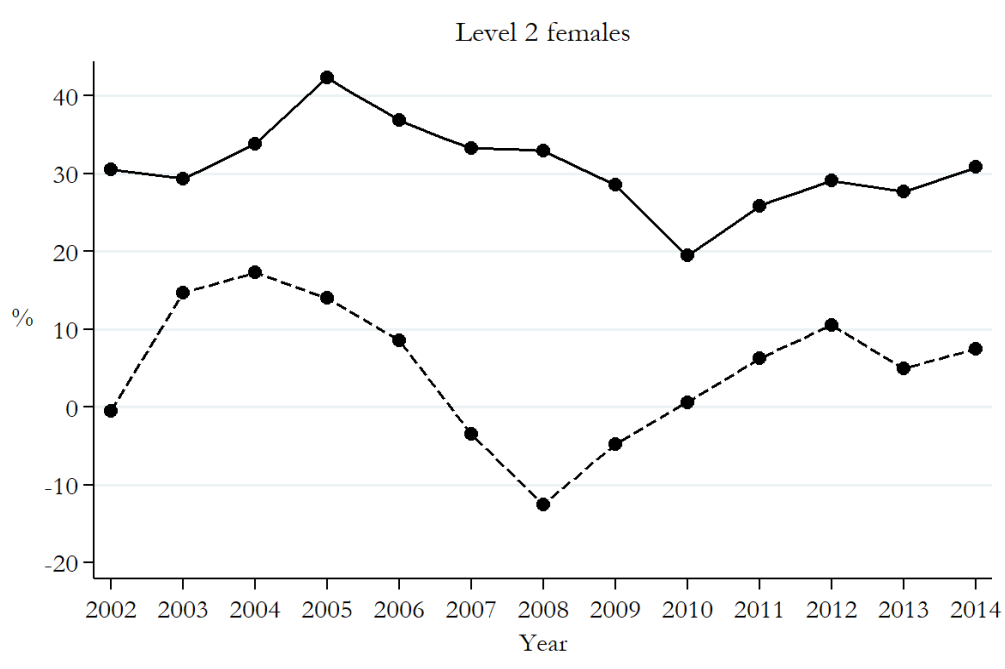

Level 3 females
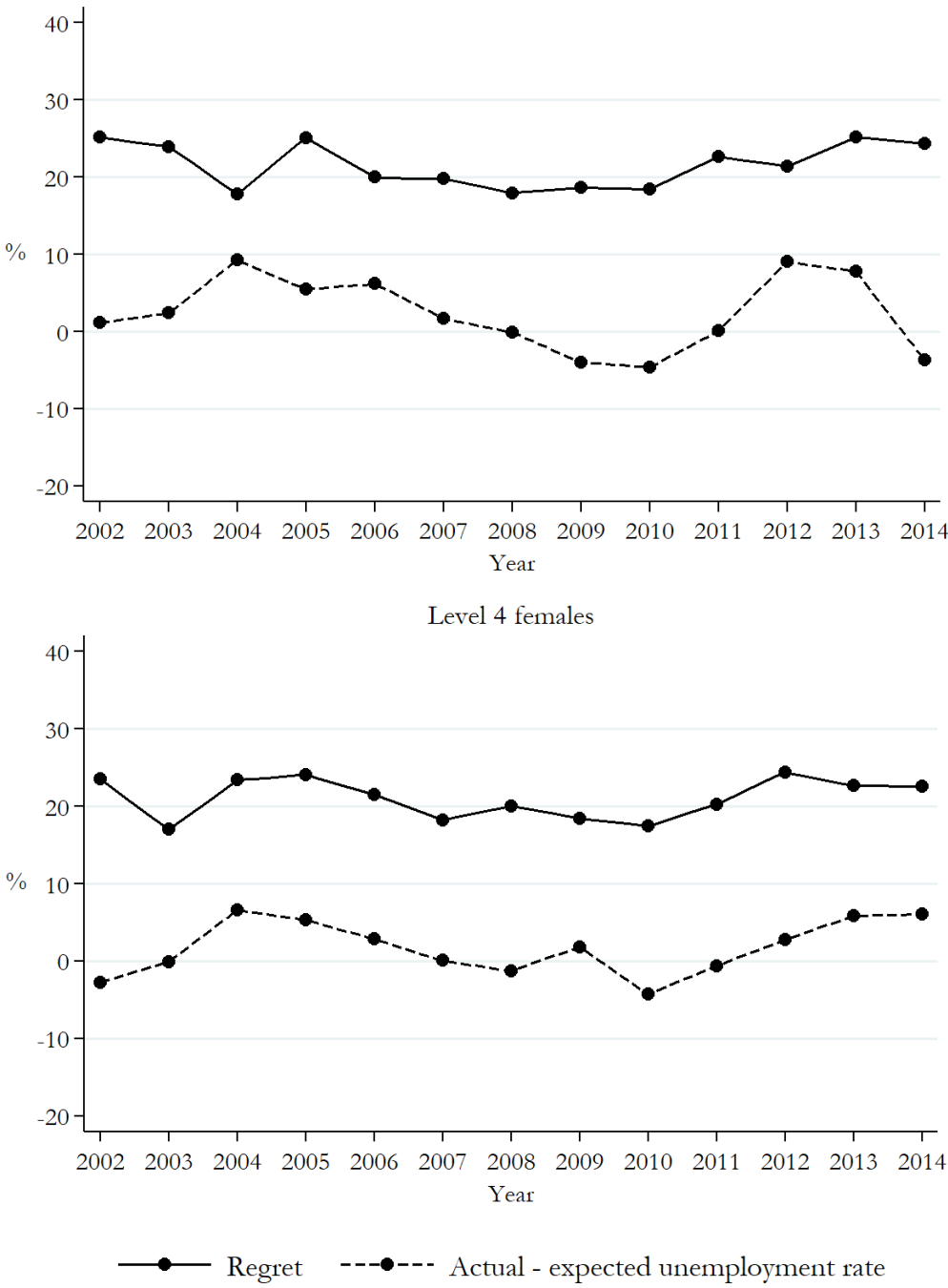

Notes: Each graph presents for every gender and level of education combination: 1) the percentage of graduates reporting regret of their field-of-study choice (solid lines) and, 2) the average discrepancy between the actual and expected field-specific unemployment rate (dashed lines). 
There appears to be a positive relation between the share of graduates reporting regret and the discrepancy between the unemployment rate at time of the field-of-study choice and labour market entry. ${ }^{46}$ The higher the actual unemployment rate is compared to the expected unemployment rate, the more likely a graduate is to experience regret. Concerning the share of graduates reporting regret, graduates from level 4 appear to be least likely to regret the chosen educational path. The percentage of individuals who report regret is higher for level 2 and 3.

\subsubsection{Model estimates}

The marginal effects from the model estimates for male and females are reported in Tables 5.3 and 5.4 respectively. Model $1 \mathrm{a}$ in Table 5.3 indicates that, for males, there is a positive association between regret and the extent to which the actual unemployment rate faced upon labour market entry deviates from the unemployment rate when the field-ofstudy was chosen (significant at the 1 percent-level). This also holds once background characteristics (age, GPA, the field-of-study, and the level of education) are controlled for (model 1b), although the relation is less strong than the raw correlation reported in model 1a. According to model 1b, a 1-unit increase in the discrepancy between the actual and expected unemployment rate is associated with a 0.2 percentage points increase in the probability that a male graduate reports regret of the chosen field-of-study. Table 5.4 shows that the relation between changes in the unemployment rate and the probability to experience regret is similar in magnitude for females in the baseline model, but only significant at the 10 percent-level (model 1a). This relationship becomes insignificant once background characteristics are accounted for in model 1b. Model $1 \mathrm{~b}$ indicates that the probability of regret is significantly lower for male as well as female graduates with higher grades. Compared to secondary vocational education graduates from the lowest level, graduates from the second and third level are less likely to report regret. This holds for male as well as females. All in all, the results support hypothesis 1 for the male sample, but not for the female sample. These findings are in line with hypothesis 2 .

\footnotetext{
46 The correlation between the share of graduates reporting regret in a certain year and the average discrepancy between actual and expected unemployment rates faced by those graduates in that year is 0.358 for males and 0.341 for females. Both correlations are significant at the 5 percent level.
} 
Chapter 5

Table 5.3: Probit estimates for the relation between regret and unanticipated labour market conditions for male graduates

\begin{tabular}{|c|c|c|c|c|}
\hline$y=$ regret & model(1a) & $\operatorname{model}(1 \mathrm{~b})$ & $\operatorname{model}(2 \mathrm{a})$ & $\operatorname{model}(2 \mathrm{~b})$ \\
\hline $\begin{array}{l}\text { Actual - expected unemployment rate } \\
\qquad\left(\mathrm{U}_{a f l}-\mathrm{U}_{e f l}\right)\end{array}$ & $\begin{array}{c}0.002^{* * *} \\
(0.001)\end{array}$ & $\begin{array}{l}0.001 * \\
(0.001)\end{array}$ & $\begin{array}{c}0.001 \\
(0.001)\end{array}$ & $\begin{array}{l}0.001 * * \\
(0.001)\end{array}$ \\
\hline \multicolumn{5}{|l|}{$\underline{\text { Personal Characteristics }}$} \\
\hline Age & & $\begin{array}{c}-0.004 * * * \\
(0.001)\end{array}$ & $\begin{array}{c}-0.004 * * * \\
(0.001)\end{array}$ & $\begin{array}{c}-0.004 * * * \\
(0.001)\end{array}$ \\
\hline GPA & & $\begin{array}{c}-0.045^{* * *} \\
(0.008)\end{array}$ & $\begin{array}{c}-0.043^{* * *} \\
(0.008)\end{array}$ & $\begin{array}{c}-0.034 * * * \\
(0.009)\end{array}$ \\
\hline \multicolumn{5}{|l|}{ Field-of-study } \\
\hline Humanities and Arts & & $\begin{array}{l}-0.031 \\
(0.105)\end{array}$ & $\begin{array}{l}-0.024 \\
(0.100)\end{array}$ & $\begin{array}{c}0.020 \\
(0.076)\end{array}$ \\
\hline Social sciences, Business and Law & & $\begin{array}{l}-0.042 \\
(0.103)\end{array}$ & $\begin{array}{l}-0.029 \\
(0.099)\end{array}$ & $\begin{array}{c}0.010 \\
(0.074)\end{array}$ \\
\hline Science, Mathematics and Computing & & $\begin{array}{l}-0.068 \\
(0.103)\end{array}$ & $\begin{array}{l}-0.055 \\
(0.099)\end{array}$ & $\begin{array}{c}0.019 \\
(0.075)\end{array}$ \\
\hline Engineering, Manufacturing and & & $\begin{array}{l}-0.112 \\
(0.103)\end{array}$ & $\begin{array}{l}-0.095 \\
(0.099)\end{array}$ & $\begin{array}{l}-0.019 \\
(0.074)\end{array}$ \\
\hline Agriculture and Veterinary & & $\begin{array}{l}-0.099 \\
(0.103)\end{array}$ & $\begin{array}{l}-0.081 \\
(0.099)\end{array}$ & $\begin{array}{l}-0.019 \\
(0.075)\end{array}$ \\
\hline Health and Welfare & & $\begin{array}{l}-0.082 \\
(0.104)\end{array}$ & $\begin{array}{l}-0.067 \\
(0.100)\end{array}$ & $\begin{array}{c}0.013 \\
(0.076)\end{array}$ \\
\hline Services & & $\begin{array}{l}-0.087 \\
(0.103)\end{array}$ & $\begin{array}{l}-0.069 \\
(0.099)\end{array}$ & $\begin{array}{l}-0.006 \\
(0.075)\end{array}$ \\
\hline \multicolumn{5}{|l|}{$\underline{\text { Level of Education }}$} \\
\hline Level 3 & & $\begin{array}{l}-0.013 \\
(0.013)\end{array}$ & $\begin{array}{l}-0.009 \\
(0.014)\end{array}$ & $\begin{array}{c}0.007 \\
(0.016)\end{array}$ \\
\hline Level 4 & & $\begin{array}{c}-0.051 * * * \\
(0.012)\end{array}$ & $\begin{array}{c}-0.044^{* * *} \\
(0.012)\end{array}$ & $\begin{array}{l}-0.020 \\
(0.014)\end{array}$ \\
\hline \multicolumn{5}{|l|}{ Individual Succes } \\
\hline Unemployment & & & $\begin{array}{c}0.108^{* * *} \\
(0.014)\end{array}$ & \\
\hline Ln(wage) & & & & $\begin{array}{l}-0.000 \\
(0.011)\end{array}$ \\
\hline Horizontal mismatch & & & & $\begin{array}{c}0.126^{* * *} \\
(0.010)\end{array}$ \\
\hline Vertical mismatch & & & & $\begin{array}{c}0.055^{* * *} \\
(0.009)\end{array}$ \\
\hline Number of clusters & 253 & 253 & 253 & 250 \\
\hline Number of observations & 10,715 & 10,715 & 10,715 & 8,564 \\
\hline Pseudo $R^{2}$ & 0.001 & 0,012 & 0.018 & 0.044 \\
\hline
\end{tabular}

Notes: The reference category for field-of-study is education. The reference category for level of education is level 2. The table reports the marginal effects at the sample mean. Standard errors clustered at the level of field-of-study, level of education, and year of participation are in parentheses. Asterisks indicate significance level: ${ }^{*} \mathrm{p}<0.10,{ }^{* *} \mathrm{p}<0.05,{ }^{* * *} \mathrm{p}<0.01$. 
Table 5.4: Probit estimates for the relation between regret and unanticipated labour market conditions for female graduates

\begin{tabular}{|c|c|c|c|c|}
\hline $\mathrm{y}=$ regret & model(1a) & $\operatorname{model}(1 \mathrm{~b})$ & $\operatorname{model}(2 \mathrm{a})$ & $\operatorname{model}(2 \mathrm{~b})$ \\
\hline $\begin{array}{l}\text { Actual - expected unemployment rate } \\
\quad\left(\mathrm{U}_{a f l}-\mathrm{U}_{e f l}\right)\end{array}$ & $\begin{array}{l}0.002 * \\
(0.001)\end{array}$ & $\begin{array}{c}0.001 \\
(0.001)\end{array}$ & $\begin{array}{c}0.000 \\
(0.001)\end{array}$ & $\begin{array}{l}-0.000 \\
(0.001)\end{array}$ \\
\hline \multicolumn{5}{|l|}{ Personal Characteristics } \\
\hline Age & & $\begin{array}{c}0.001 \\
(0.001)\end{array}$ & $\begin{array}{c}0.000 \\
(0.001)\end{array}$ & $\begin{array}{l}-0.000 \\
(0.001)\end{array}$ \\
\hline GPA & & $\begin{array}{c}-0.023 * * * \\
(0.006)\end{array}$ & $\begin{array}{c}-0.020^{* * *} \\
(0.006)\end{array}$ & $\begin{array}{c}-0.015^{* *} \\
(0.007)\end{array}$ \\
\hline \multicolumn{5}{|l|}{ Field-of-study } \\
\hline Humanities and Arts & & $\begin{array}{l}-0.066 \\
(0.053)\end{array}$ & $\begin{array}{l}-0.062 \\
(0.054)\end{array}$ & $\begin{array}{l}-0.046 \\
(0.042)\end{array}$ \\
\hline Social sciences, Business and Law & & $\begin{array}{l}-0.042 \\
(0.051)\end{array}$ & $\begin{array}{l}-0.037 \\
(0.052)\end{array}$ & $\begin{array}{l}-0.015 \\
(0.041)\end{array}$ \\
\hline Science, Mathematics and Computing & & $\begin{array}{c}-0.136 * * \\
(0.069)\end{array}$ & $\begin{array}{l}-0.138^{* *} \\
(0.067)\end{array}$ & $\begin{array}{l}-0.072 \\
(0.068)\end{array}$ \\
\hline Engineering, Manufacturing and & & $\begin{array}{l}-0.045 \\
(0.054)\end{array}$ & $\begin{array}{l}-0.041 \\
(0.055)\end{array}$ & $\begin{array}{l}-0.016 \\
(0.046)\end{array}$ \\
\hline Agriculture and Veterinary & & $\begin{array}{l}-0.048 \\
(0.053)\end{array}$ & $\begin{array}{l}-0.045 \\
(0.054)\end{array}$ & $\begin{array}{l}-0.046 \\
(0.043)\end{array}$ \\
\hline Health and Welfare & & $\begin{array}{c}-0.117 * * \\
(0.050)\end{array}$ & $\begin{array}{l}-0.108^{* *} \\
(0.051)\end{array}$ & $\begin{array}{l}-0.045 \\
(0.040)\end{array}$ \\
\hline Services & & $\begin{array}{l}-0.064 \\
(0.050)\end{array}$ & $\begin{array}{l}-0.054 \\
(0.052)\end{array}$ & $\begin{array}{l}-0.024 \\
(0.041)\end{array}$ \\
\hline \multicolumn{5}{|l|}{ Level of Education } \\
\hline Level 3 & & $\begin{array}{c}-0.058^{* * *} \\
(0.012)\end{array}$ & $\begin{array}{c}-0.047 * * * \\
(0.012)\end{array}$ & $\begin{array}{c}-0.032^{* *} \\
(0.013)\end{array}$ \\
\hline Level 4 & & $\begin{array}{c}-0.078^{* * *} \\
(0.011)\end{array}$ & $\begin{array}{c}-0.064 * * * \\
(0.011)\end{array}$ & $\begin{array}{c}-0.041 * * * \\
(0.013)\end{array}$ \\
\hline \multicolumn{5}{|l|}{ Individual Succes } \\
\hline Unemployment & & & $\begin{array}{c}0.116^{* * *} \\
(0.010)\end{array}$ & \\
\hline Realized wage - expected wage & & & & $\begin{array}{l}-0.012 \\
(0.009)\end{array}$ \\
\hline Horizontal mismatch & & & & $\begin{array}{c}0.155^{* * *} \\
(0.008)\end{array}$ \\
\hline Vertical mismatch & & & & $\begin{array}{c}0.029 * * * \\
(0.009)\end{array}$ \\
\hline Number of clusters & 251 & 251 & 251 & 245 \\
\hline Number of observations & 19,975 & 19,975 & 19,975 & 15,633 \\
\hline Pseudo $R^{2}$ & 0.001 & 0.012 & 0.018 & 0.047 \\
\hline
\end{tabular}

Notes: The reference category for field-of-study is education. The reference category for level of education is level 2. The table reports the marginal effects at the sample mean. Standard errors clustered at the level of field-of-study, level of education, and year of participation are in parentheses. Asterisks indicate significance level: ${ }^{*} \mathrm{p}<0.10,{ }^{* *} \mathrm{p}<0.05,{ }^{* * *} \mathrm{p}<0.01$. 
The main explanatory variable turns insignificant when graduates' employment status is included in the model for both the male and female sample (model 2a). Model 2b excludes graduates who are unemployed at the time of the survey and controls for the mismatch indicators and the logarithm of graduates' wage. ${ }^{47}$ Model $2 \mathrm{~b}$ shows that being in a job that does not match the attended field or level of education significantly increases the likelihood of experiencing regret for male as well as female graduates. More interestingly, for males, the coefficient indicating the discrepancy between the expected and actual unemployment is again significant, positive and similar in magnitude to the coefficient reported in model $1 \mathrm{~b}$, independent of employed graduates' success in the labour market. Hence, the findings for male graduates do not support hypothesis 3 . For females, the main explanatory variable of interest remains insignificant once the model accounts for their actual labour market outcomes. Female graduates are unaffected by changes in labour market conditions, independent of their own labour market outcomes. Therefore, the estimates obtained in model $2 \mathrm{a}$ and $2 \mathrm{~b}$ do also not support the conjecture expressed in hypothesis 3 for females. This means that, at least for males, a deviation of actual labour market conditions compared to expectations generates regret, irrespective of one's own labour market success.

\subsubsection{Asymmetry of labour market changes}

Based on the results presented in Tables 5.3 and 5.4, it is not clear whether the relationship between regret and the discrepancy between the expected and actual unemployment rate is symmetric. To test for this (H4), we split the sample to distinguish between labour market entrants for whom the labour market situation is worse than expected (Table 5.5) and labour market entrants who face a lower unemployment rate upon graduation than expected (Table 5.6). Note that Table 5.6 takes the absolute value of the discrepancy between the actual unemployment rate upon labour market entry and the expected unemployment rate at the time of study choice as the independent variable of interest.

For male graduates, there is a significant relation between facing labour market conditions that are worse than expected and regret once background characteristics (age, GPA, the field-of-study, and the level of education) and labour market outcomes (employment status, log wage, horizontal mismatch, vertical mismatch) are accounted for (Table 5.5). The coefficients are also larger than in the full sample (Table 5.3) In contrast, male graduates do not experience less regret when labour market conditions are better than

\footnotetext{
${ }^{47}$ When model $1 \mathrm{a}$ and $1 \mathrm{~b}$ in Table 5.3 and 5.4 are run without individuals who are unemployed at the time of the survey (similar number of observations as in model $2 b$ ), the coefficient of the explanatory variable of interest in model 1a (Table 5.4) turns insignificant. This leaves our conclusions based on Table 5.3 and 5.4 unchanged.
} 
expected upon labour market entry (Table 5.6). Hence, the estimates in Section 5 are not symmetric and mainly driven by unfavourable deviations in the field-specific unemployment rate. Hence, the results are in line with hypothesis 4 for male graduates.

There is no significant relationship between the probability of experiencing regret and facing labour market conditions that are worse than expected for female graduates (Table 5.5). The same holds for the relationship between regret and entering the labour market in conditions that are better than at the time of study choice (Table 5.6). Hence, hypothesis 4 does not hold for female graduates.

Table 5.5: Cases facing a higher unemployment rate upon labour market entry than expected

\begin{tabular}{lcccc}
\hline \hline & \multicolumn{2}{c}{ Male } & \multicolumn{2}{c}{ Female } \\
$\mathrm{y}=$ regret & $\operatorname{model}(2 \mathrm{a})$ & $\operatorname{model}(2 \mathrm{~b})$ & $\operatorname{model}(2 \mathrm{a})$ & $\operatorname{model}(2 \mathrm{~b})$ \\
\hline Actual - expected unemployment rate & $0.002^{* *}$ & $0.002^{* *}$ & 0.000 & 0.000 \\
$\left(\mathrm{U}_{\text {afl }}>\mathrm{U}_{\text {efl }}\right)$ & $(0.001)$ & $(0.001)$ & $(0.001)$ & $(0.001)$ \\
Control variables & Yes & Yes & Yes & Yes \\
\hline Number of clusters & 172 & 169 & 169 & 165 \\
Number of observations & 7,502 & 5,91 & 13,875 & 10,805 \\
Pseudo $R^{2}$ & 0.016 & 0.046 & 0.017 & 0.053 \\
\hline \hline
\end{tabular}

Notes: The table reports the marginal effects at the sample mean. Standard errors clustered at the level of field-of-study, level of education, and year of participation are in parentheses. Asterisks indicate significance level: ${ }^{*} \mathrm{p}<0.10,{ }^{* *} \mathrm{p}<0.05,{ }^{* * *} \mathrm{p}<0.01$. Model 2a controls for age, GPA, field-of-study, level of education, and employment status. Model $2 \mathrm{~b}$ controls for log wage, horizontal mismatch, and vertical mismatch. Model 2b excludes graduates who are unemployed.

Table 5.6: Cases facing a lower unemployment rate upon labour market entry than expected

\begin{tabular}{lcccc}
\hline \hline & \multicolumn{2}{c}{ Male } & \multicolumn{2}{c}{ Female } \\
$\mathrm{y}=$ regret & $\operatorname{model}(2 \mathrm{a})$ & $\operatorname{model}(2 \mathrm{~b})$ & $\operatorname{model}(2 \mathrm{a})$ & $\operatorname{model}(2 \mathrm{~b})$ \\
\hline Actual - expected unemployment rate & 0.001 & -0.000 & 0.002 & 0.002 \\
$\left(\mathrm{U}_{\text {afl }}<\mathrm{U}_{\text {efl }}\right)$ & $(0.001)$ & $(0.002)$ & $(0.002)$ & $(0.002)$ \\
Control variables & Yes & Yes & Yes & Yes \\
\hline Number of clusters & 79 & 79 & 81 & 78 \\
Number of observations & 3,210 & 2,652 & 6,096 & 4,824 \\
Pseudo R & 0.026 & 0.044 & 0.023 & 0.036 \\
\hline \hline
\end{tabular}

Notes: The table reports the marginal effects at the sample mean. Standard errors clustered at the level of field-of-study, level of education, and year of participation are in parentheses. Asterisks indicate significance level: ${ }^{*} \mathrm{p}<0.10,{ }^{* *} \mathrm{p}<0.05,{ }^{* * *} \mathrm{p}<0.01$. Model $2 \mathrm{a}$ controls for age, GPA, field-of-study, level of education, and employment status. Model $2 \mathrm{~b}$ controls for log wage, horizontal mismatch, and vertical mismatch. Model $2 \mathrm{~b}$ excludes graduates who are unemployed. The independent variable of interest is the absolute value of the discrepancy between the actual unemployment rate upon labour market entry and the expected unemployment rate at the time of study choice. 


\subsubsection{Robustness}

In line with Borghans and Golsteyn (2005), we assumed in this study that students gather information about the future labour market in the year prior to enrolment in the study programme. Hence, we compared the actual field and level specific unemployment rate at labour market entry with the unemployment rate in $t-d$, where $d$ is the length of the study programme plus 1.5 years (time between the end of the study programme and the time of the survey) plus 1 year. As a robustness check, we decrease $d$ by one year as students might also gather information about the field-specific labour market outcomes just before enrolling in a specific programme. ${ }^{48}$ For male as well as female graduates, the results are not significantly different from the results that are obtained when we compare the unemployment rate at labour market entry with the unemployment rate one year prior to enrolment in the study programme.

\subsection{Conclusion and discussion}

Despite the societal and economic relevance of making adequate educational choices, literature on the determinants of regretting the chosen field-of-study remains scarce. The aim of this study is to investigate to what extent the experience of regret is related to unanticipated changes in field-specific labour market conditions. We focussed on graduates from Dutch secondary vocational education as changes in labour market conditions entail particular relevance for these graduates due to the strong linkage between the skills learned at school and the employers' occupational demands for such skills. Students are likely to make prediction errors regarding their future labour market outcomes when accurate and detailed labour market forecasts are unavailable and expectations are formed based on labour market outcomes from prior cohorts. If the outcomes from previous cohorts do not adequately reflect the future skills needs, youngsters choosing fields that are in oversupply will face unexpectedly high rates of unemployment which could cause them to experience regret of the chosen field-of-study.

Although we do not directly observe graduates' expectations when they entered a study programme in our data, we assume they gathered relevant information in the year prior to entry by observing unemployment rates from earlier cohorts of graduates. We then measure the discrepancy between expectations and realisation by comparing the unemployment rate by level and field-of-study. Changes in labour market conditions cause a selection of entrants into the labour market as graduates are more likely to continue in education when labour market conditions deteriorate. Consequently, we obtain lower bound estimates of the relation between changes in unanticipated labour

\footnotetext{
48 The results are not shown, but available on request.
} 
market conditions and the probability that graduates experience regret. ${ }^{49}$ Our empirical analyses show that the probability of experiencing regret increases with the differences between actual unemployment rates at time of labour market entry and expected unemployment rates at the time when study choices were made. This finding only holds for male graduates and is especially driven by graduates who face labour market circumstances that are worse than they expected. The results for male graduates are in line with prior research indicating that individuals attach more weight to worse-than-expected outcomes than to better-than-expected outcomes (Landman, 1987). Females appear to be unaffected by a deterioration of labour market conditions. This gender difference could be driven by the fact that males and females make education and career choices on different grounds, males giving more attention to pecuniary aspects of their future job than do females (Zafar, 2013). Another potential reason for the male-female difference is that females sort into fields (e.g. healthcare) that are more stable across business cycles. For males, a deterioration of labour market entry conditions compared to expectations generates regret, irrespective of males' own labour market success. This could reflect that changes in labour market conditions are also accompanied by increased labour market insecurity and an associated greater difficulty of finding a job which can induce regret. ${ }^{50}$

A number of policy implications can be drawn from this study. While young graduates can readdress their educational choices, the negative consequences of regretting the chosen field-of-study are considerable, independent of whether or not graduates decide to rectify the choices they previously made (Borghans \& Golsteyn, 2006). A core reason explaining why a high percentage of graduates report to regret their educational choices when the labour market conditions are worse than expected is the asymmetry of labour market information. The labour market is very complex, whereas students who have to choose which field-of-study to enrol in are rather inexperienced in making such important choices. Ideally, policy makers could improve students' educational choices by providing them with up to date information about the future labour market prospects by field-ofstudy, and support them in digesting this information. Such forecasts are especially crucial for vocational programmes, since these tracks are more sensitive to changes in labour market conditions. The quality of educational choices therefore depends, among other

\footnotetext{
${ }^{49}$ In our dataset, we observe a positive and significant correlation between re-enrolment in education and the field specific unemployment rate in the final year of the study programme.

50 Our dataset includes a variable indicating the number of months graduates were unemployed before finding their first job. We did not include this variable in our main analyses due to the large number of missing cases $(n=8,913)$. When we include this variable in model $2 \mathrm{~b}$ in Table 5.3 , the coefficient on the main dependent variable of interest becomes 0.097 and turns insignificant and the coefficient indicating the unemployment duration is positive and significant at the 1 percent percent level. This suggests that, independent of males' labour market outcomes, changes in labour market conditions can induce regret due to the greater difficulty of finding a job.
} 


\section{Chapter 5}

things, on the extent to which students have access to information on (field-specific) returns to education, and are able to anticipate the outcome of various schooling alternatives.

Besides increasing the availability of accurate labour market forecasts, policy makers should ensure that students can process labour market information and incorporate it into the decision making process. While some studies found that students reconsider their study choice or labour market expectations in a rational way based on new information (Hastings et al., 2015; Jensen, 2010; Oreopoulos \& Dunn, 2013; Wiswall \& Zafar, 2014; Zafar, 2011), other studies found almost no effect of providing students with labour market information on students' study choice (Pekkala Kerr et al., 2015). Hence, special attention must be given to making vocational education students receptive to accurate labour market forecasts. 
Appendix 5.1: Results when the actual unemployment rate is gender specific and the expected unemployment rate is non-gender specific

\section{Table 5.7: Relation between regret and unanticipated labour market conditions}

\begin{tabular}{lcccc}
\hline \hline & \multicolumn{2}{c}{ Male } & \multicolumn{2}{c}{ Female } \\
$\mathrm{y}=$ regret & $\operatorname{model}(2 \mathrm{a})$ & $\operatorname{model}(2 \mathrm{~b})$ & $\operatorname{model}(2 \mathrm{a})$ & $\operatorname{model}(2 \mathrm{~b})$ \\
\hline Actual - expected unemployment rate & 0.001 & $0.001 * *$ & -0.000 & -0.000 \\
$\quad\left(\mathrm{U}_{\text {afl }}-\mathrm{U}_{\text {efl }}\right)$ & $(0.001)$ & $(0.001)$ & $(0.001)$ & $(0.001)$ \\
Control variables & Yes & Yes & Yes & Yes \\
\hline Number of clusters & 253 & 250 & 251 & 245 \\
Number of observations & 10,803 & 8.653 & 19,852 & 15,507 \\
Pseudo $\mathrm{R}^{2}$ & 0,018 & 0,044 & 0,018 & 0,047 \\
\hline \hline
\end{tabular}

Notes: The table reports the marginal effects at the sample mean. Standard errors clustered at the level of field-of-study, level of education, and year of participation are in parentheses. Asterisks indicate significance level: ${ }^{*} \mathrm{p}<0.10,{ }^{* *} \mathrm{p}<0.05,{ }^{* * *} \mathrm{p}<0.01$. Model 2a controls for age, GPA, field-of-study, level of education, and employment status. Model $2 \mathrm{~b}$ controls for log wage, horizontal mismatch, and vertical mismatch. Model 2b excludes graduates who are unemployed.

Table 5.8: Cases facing a higher unemployment rate upon labour market entry than expected

\begin{tabular}{lcccc}
\hline \hline & \multicolumn{2}{c}{ Male } & \multicolumn{2}{c}{ Female } \\
$\mathrm{y}=$ regret & $\operatorname{model}(2 \mathrm{a})$ & $\operatorname{model}(2 \mathrm{~b})$ & $\operatorname{model}(2 \mathrm{a})$ & $\operatorname{model}(2 \mathrm{~b})$ \\
\hline Actual - expected unemployment rate & $0.002^{* *}$ & $0.002^{*}$ & -0.001 & -0.001 \\
$\left(\mathrm{U}_{\text {afl }}>\mathrm{U}_{\text {efl }}\right)$ & $(0.001)$ & $(0.001)$ & $(0.001)$ & $(0.001)$ \\
Control variables & Yes & Yes & Yes & Yes \\
\hline Number of clusters & 143 & 140 & 160 & 155 \\
Number of observations & 6.999 & 5,513 & 13,790 & 10,714 \\
Pseudo $R^{2}$ & 0,018 & 0,048 & 0,017 & 0,051 \\
\hline \hline
\end{tabular}

Notes: The table reports the marginal effects at the sample mean. Standard errors clustered at the level of field-of-study, level of education, and year of participation are in parentheses. Asterisks indicate significance level: ${ }^{*} \mathrm{p}<0.10,{ }^{* *} \mathrm{p}<0.05,{ }^{* * *} \mathrm{p}<0.01$. Model 2a controls for age, GPA, field-of-study, level of education, and employment status. Model $2 \mathrm{~b}$ controls for log wage, horizontal mismatch, and vertical mismatch. Model 2b excludes graduates who are unemployed. 
Chapter 5

Table 5.9: Cases facing a lower unemployment rate upon labour market entry than expected

\begin{tabular}{lcccc}
\hline \hline & \multicolumn{2}{c}{ Male } & \multicolumn{2}{c}{ Female } \\
$\mathrm{y}=$ regret & $\operatorname{model}(2 \mathrm{a})$ & $\operatorname{model}(2 \mathrm{~b})$ & $\operatorname{model}(2 \mathrm{a})$ & $\operatorname{model}(2 \mathrm{~b})$ \\
\hline Actual - expected unemployment rate & -0.001 & -0.002 & 0.002 & 0.002 \\
$\left(\mathrm{U}_{\text {afl }}<\mathrm{U}_{\text {efl }}\right)$ & $(0.001)$ & $(0.002)$ & $(0.002)$ & $(0.002)$ \\
Control variables & Yes & Yes & Yes & Yes \\
\hline Number of clusters & 105 & 105 & 83 & 82 \\
Number of observations & 3.768 & 3,107 & 6,043 & 4,775 \\
Pseudo $R^{2}$ & 0,022 & 0,044 & 0,024 & 0,042 \\
\hline \hline
\end{tabular}

Notes: The table reports the marginal effects at the sample mean. Standard errors clustered at the level of field-of-study, level of education, and year of participation are in parentheses. Asterisks indicate significance level: ${ }^{*} \mathrm{p}<0.10,{ }^{* *} \mathrm{p}<0.05,{ }^{* * *} \mathrm{p}<0.01$. Model 2a controls for age, GPA, field-of-study, level of education, and employment status. Model $2 \mathrm{~b}$ controls for log wage, horizontal mismatch, and vertical mismatch. Model $2 \mathrm{~b}$ excludes graduates who are unemployed. The independent variable of interest is the absolute value of the discrepancy between the actual unemployment rate upon labour market entry and the expected unemployment rate at the time of study choice. 




\section{Part 3}

Gaining Insight Into Future Labour Demand 



\section{Chapter 6}

\section{The Changing Demand for Skills in the Netherlands ${ }^{51,52,53}$}

51 This study is based on: Somers, M. A., Cabus, S. J., Groot, W., \& Maassen van den Brink, H. (2019). The changing demand for skills in the Netherlands. House of Skills Working Paper Series. ISBN 978-90-830241-1-0.

52 This study benefitted from discussions with participants of the ROA Workshop on Dynamics of Skills Supply and Demand, participants of the 16 th Belgian Day for Labour Economists, and participants of the International Conference on Education Economics.

${ }^{53}$ This study was financially supported by 'House of Skills'. The partners of 'House of Skills' were not involved in the preparation of this chapter. 


\title{
Chapter 6
}

\begin{abstract}
This chapter examines the wage returns and changes in the returns for workers employed in occupations that are intensive in tasks requiring non-routine analytical and non-routine interpersonal skills in the Netherlands during the period 2001-2016. We match measures of skills from the US O*NET system to the International Standard Occupation Classification (ISCO). We combine these data with information on employment and wages from administrative data from Statistics Netherlands. We document an increase in the returns to analytical skills, from 9.4 percent in 2001 to 16.0 percent in 2016. Quantile regressions show that the increase in returns from analytical skills can be observed for workers in the lower-, middle-, as well as upper-end of the wage distribution. These findings suggests that non-routine analytical skills are increasingly rewarded on the Dutch labour market. This is consistent with the idea that computer technologies are complementary to the skills required to perform non-routine tasks. With respect to interpersonal skills, we only document a small increase in the wage premium for full-time workers in the upper-end of the wage distribution, from 5.8 percent in 2001 to 7.4 percent in 2016. This finding suggests that increased organisational complexity - induced by technological advances - has put greater demands on interpersonal and managerial skills.
\end{abstract}




\subsection{Introduction}

It is widely acknowledged that skills play an important role in knowledge-based economies (Hanushek \& Woessmann, 2008; Hanushek \& Woessmann, 2012). However, estimates of how skills are valued in the labour market rely for a large part on schooling attainment measures of human capital (see e.g. Card, 1999; Harmon, Oosterbeek \& Walker, 2003; Heckman, Lochner \& Todd, 2006; Montenegro \& Patrinos, 2014; Psacharopoulos \& Patrinos, 2004). Although basic Mincer equation estimates consistently show that higher levels of educational attainment are associated with higher earnings (Harmon et al., 2003), earnings differentials across college majors can sometimes be larger than the college-high school earnings premium (Altonji, Blom \& Meghir, 2012; Kirkebøen, Leuven \& Mogstad, 2016). In some countries the wage dispersion among workers with similar levels of schooling has substantially increased in recent decades (Acemoglu \& Autor, 2011; Budría \& Moro-Egido, 2008; Gosling, Machin \& Meghir, 2000; Ingram \& Neumann, 2006). These observations point toward unobserved skill heterogeneity within education groups and illustrate that educational attainment alone is not a complete measure of skill. ${ }^{54}$ The increased earnings inequality within education groups suggests that the type of skills that are acquired both within and outside formal education are an important determinant of graduates' labour market success (Altonji et al., 2012). Providing insight into how skills are rewarded in the labour market will help to inform those who develop educational curricula as well as those investing in their human capital about the skills that are required in employment today, and in the future.

This chapter examines how different types of skills are rewarded on the Dutch labour market and how this has changed over the period 2001-2016. In particular, we investigate how the wage premium for being employed in a job that is intensive in non-routine tasks has developed over the past two decades. According to the routinization hypothesis (Autor et al., 2003), technological improvements have reduced the demand for skills required to perform routine tasks, while they have increased the demand for skills required to perform non-routine abstract tasks. ${ }^{55}$ Skills (embodied in human labour) and technologies (embodied in capital) can be considered competing inputs for the performance of different tasks (Acemoglu \& Autor, 2011). Firms decide on the optimal

\footnotetext{
54 Advocates of the sorting model argue that formal schooling does not necessarily raise skills, but acts as a signalling device for unobservable ability. According to this model, students sort into an educational level to signal their ability to potential employers and firms infer graduates' innate ability from their educational qualifications (Bedard, 2001; Spence, 1973; Thurow, 1975).

55 With "routine" we refer to tasks that are routine from a machine execution perspective. Machines and computers can substitute for human labour in tasks that can be expressed in 'rule-based' logic. In other words, tasks can be automated when they can be codified in a sequence of logical 'if-then-do' statements that instruct machines which actions need to be performed under which conditions.
} 
allocation of skills to tasks according to the prices of different inputs and the productivity of these inputs in specific tasks. The increase in computing power in recent decades, along with the declining price of computation, has created an economic incentive for firms to substitute machines for human labour in the performance of routine tasks (Autor, Katz \& Kearney, 2006; Goos \& Manning, 2007; Goos, et al., 2014; Michaels et al., 2014). ${ }^{56}$ Given that routine tasks can be expressed in well-defined procedures, they can be easily codified in computer software and are therefore more likely to be performed by machines (Autor et al., 2003).

While technologies largely substitute for human labour in the performance of routine tasks, the skills required to perform non-routine tasks are generally complemented by machines. In accordance with Acemoglu and Autor (2001), we distinguish between two types of non-routine abstract tasks: non-routine cognitive analytical tasks and non-routine cognitive interpersonal tasks. Occupations that are intensive in non-routine abstract tasks heavily depend on the analysis of information as an input (e.g. medical knowledge, legal precedents, sales data, and the statistical analysis of data). By lowering the cost of retrieving, organizing, and manipulating information, workers in abstract task-intensive occupations will spend less time on acquiring and manipulating information. Accordingly, computerization enables workers to further specialize in their area of comparative advantage, i.e. analysing and interpreting information. The routinization hypothesis therefore predicts that non-routine analytical skills are increasingly valued in the labour market. The capital-skill complementarity also predicts an increasing demand for interpersonal skills. As computer technologies have reduced the cost of communication, as well as the cost of diminishing direct control of workers by allowing for indirect computer-based monitoring, technological improvements have induced a decentralization of the workplace (Radner, 1993). In conjunction with these organisational changes, an increased demand is placed on workers who are capable of communicating effectively and who are able to manage and work in teams (Bresnahan, Brynjolfsson \& Hitt, 2002; Caroli \& Van Reenen, 2001).

While some recent skill measures are available for the Netherlands (e.g. Netherlands Skills Survey, NSS) and for Europe (e.g. European Skills, Competences, Qualifications and Occupations, ESCO), these are very recent and based on few respondents. In contrast to the skill measures available for the Netherlands, the US Occupational Information Network (O*NET) provides skill measures that are primarily derived from survey responses of large, representative samples of job incumbents. O*NET is the main source of occupational competency information in the United States and its measures cover

\footnotetext{
${ }^{56}$ Nordhaus (2007) estimates that computational capabilities have improved by a factor of at least 1.7 trillion since the mid nineteenth century. Most of that price decline occurred since 1980.
} 
among others things analytical and interpersonal skill requirements for almost 1,000 different occupations. O*NET started its data collection efforts in 2001 and is constantly being revised.

In the absence of a comparable data source for the Netherlands, we match the O*NET measures for non-routine skills to the International Standard Classification of Occupations 2008 (ISCO-08) to generate occupational skill profiles for the Netherlands. These occupational skill profiles can improve our understanding of changes in the rewards for different types of skills and, thereby, of the changing patterns in the supply and demand for skills. Skill measures from $\mathrm{O}^{*} \mathrm{NET}$ are based on the job requirements approach. ${ }^{57}$ Job skill requirements can be retrieved from job expert assessments or employee and employer surveys. In contrast to formal qualifications, the skill measures that are based on the job requirements approach have the advantage to be more strongly linked to the skills actually used in jobs (Green, 2006). Not all skills acquired through formal schooling are used in the labour market due to skill depreciation and the continuation of skill acquisition after labour market entry.

To the best of our knowledge, this is the first study to document long-run trends in the returns to analytical and interpersonal skills for the Netherlands. In contrast to most previous studies on trends in the returns to skills (e.g. Deming, 2017; Beaudry, Green \& Sand, 2016; Castex \& Kogan Dechter, 2014; Ingram \& Neumann, 2006), we investigate whether (changes) in the returns are driven by workers in specific segments of the wage distribution by drawing on quantile regression techniques. To examine how the rewards for skills have developed over time, we link the skills data from O*NET to rich administrative data on employment and wages from Statistics Netherlands.

The remainder of this chapter unfolds as follows. The next section reviews previous studies that have estimated the returns to skills required for the performance of nonroutine tasks over time in a variety of countries. Next, this chapter describes the data and presents the empirical model. This chapter then presents the patterns in the estimates of the returns to skills and shows how the estimates differ for different segments of the wage distribution. Finally, this chapter concludes and provides a discussion of potential implications of our findings for skill policy in the Netherlands.

57 Other datasets containing skill requirements by occupations include the IAB/BIBB surveys on Qualification and Working Conditions in Germany (see e.g. Borghans, Ter Weel \& Weinberg, 2008; Spitz-Oener, 2006), the British Skills Survey (see e.g. Borghans et al., 2008), the Netherlands Skills Survey (see e.g. Ter Weel \& Kok, 2013), and the Dictionary of Occupational Titles in the United States (see e.g. Autor et al., 2003), the predecessor of O*NET. 


\subsection{Related literature}

\subsubsection{Return to non-routine analytical skills}

Between the 1970s and the 1990s, the wage returns to cognitive skills increased substantially in the United States (Autor et al., 2003; Ingram \& Neumann, 2006). Many OECD countries also experienced a rapid growth since the 1950s in the employment share of managerial, professional and technical occupations that are intensive in nonroutine cognitive skills (Handel, 2012). The literature provides two explanations for the observed shift in employment towards high-skilled workers over the past decades. Advocates of the skill biased technological change (SBTC) hypothesis argue that technological change has monotonic effects throughout the skill distribution. This model predicts a uniform shift in the demand for labour away from low-skilled and towards high-skilled workers (Autor et al., 1998; Carneiro \& Lee, 2009; Katz \& Murphy, 1992). According to the SBTC hypothesis, high-skilled workers are more likely to use computers and to possess skills that complement computer-based technologies (Autor, Katz \& Krueger, 1999). Consequently, high skilled workers experience bigger productivity gains with improvements in computer technologies.

However, the SBTC hypothesis does not provide an explanation for why the United States and European countries witnessed an employment growth in both the highestskilled occupations (professional and managerial) as well as the low-skilled service occupations, and a decline in the middle of the wage distribution (Autor et al., 2006; Van den Berge \& Ter Weel, 2015; Goos \& Manning, 2007; Goos et al., 2014; Michaels et al., 2014; Smits \& De Vries, 2015). According to the task-based model, tasks can be performed by a variety of inputs, and technologies will substitute for skills depending on the price and productivity of each input (Acemoglu \& Autor, 2011). The price decline of computer capital, in combination with a strong increase in computing power, has resulted in an increased substitution of computer capital for human labour. As such, the taskbased model provides an explanation for why occupations in the middle of the skill distribution, that are intense in routine tasks, have experienced a strong employment decline (Autor et al., 2003; Spitz-Oener, 2006). This phenomenon is also referred to as job polarization (Goos \& Manning, 2007).

After two decades of growth in occupations requiring high cognitive skills, there is evidence of a declining demand for such skills in the United States after the year 2000 (Autor, 2015; Beaudry et al., 2016; Castex \& Kogan Dechter, 2014; Mishel et al., 2013). One potential explanation for changes in the demand for cognitive skills is that technological advances rapidly expand the set of tasks that can be performed by computer-based technologies (Brynjolfsson \& McAfee, 2014). Computer capital might 
increasingly substitute for labour higher up in the skill distribution, redefining what it means for work to be 'routine' (Autor, 2014; Lu, 2015). While machines already substitute human labour in performing routine tasks (e.g. assembling cars, or administrating data), computer capital becomes increasingly proficient in performing a wide range of complex tasks that are typically defined as non-routine such as driving cars and diagnosing diseases (Brynjolfsson \& McAfee, 2014). If computer capital is increasingly replacing labour in the upper-end of the skill distribution, one would expect to observe an increase in computer and software investments. However, corporate computer and software investments seem to have dropped since the 2000s (Autor, 2015). Beaudry et al. (2006) argue that the declining returns to cognitive skills are the result of the dotcom bubble bust and that progress of information technology reached maturity in the early 2000s in the United States. These findings are supported by Castex and Kogan Dechter (2014) who document that the returns to cognitive skills slightly fell in the 2000s relative to the 1980 s. They argue that this decline can be associated with a slowdown in the growth rate of technology.

Whether the Netherlands also experienced a decline in the returns to non-routine analytical skills since the early 2000s is not evident. In contrast to the recent slowdown in the growth of high-skill occupations in the Unites States, the employment share of highskill occupations expanded between 2005 and 2015 in the EU-28 (Cedefop, 2016a; Cedefop, 2016b). Moreover, Hartog and Gerritsen (2016) demonstrate that the number of computer service and information technology agencies has mushroomed after the mid1990s in the Netherlands. This trend suggests that the application of computer-based technologies has continued to rise in the Netherlands. Therefore, one would expect to observe an increasing return to analytical skills over the past two decades in the Netherlands.

\subsubsection{The return to non-routine interpersonal skills}

In contrast to routine tasks, non-routine tasks requiring significant interpersonal interaction have still proven difficult to automate (Autor, 2015; Autor et al., 2003; Deming, 2017; Frey \& Osborne, 2017). While machines are capable of reproducing some aspects of human social interaction, the real-time recognition of human emotion and the ability to respond to such inputs remains an engineering bottleneck. The task-based model predicts an improvement in the productivity and an increasing demand for labour performing tasks that are not susceptible to computerisation (Autor, 2015). Deming (2017) documents that the probability of full-time work has increased more than fourfold between 1979 and 1997 for graduates (aged 25-33) who are endowed with high interpersonal skills in the United States. During the same period, the wage returns to 
interpersonal skills almost doubled. Likewise, Borghans et al. (2014) document that the number of occupations requiring interpersonal skills - along with the monetary returns rapidly grew between the late 1970s and early 1990s in Britain, Germany and the United States.

One potential explanation for the increasing reward for interpersonal skills is skill-biased organizational change (Bresnahan et al., 2002; Caroli \& Van Reenen, 2001). According to the 'skill-biased organizational change' hypothesis, technological innovations have led organization to move toward more workplace decentralisation. ${ }^{58}$ The decentralization of authority transfers the decision-making process to teams of workers, delayers managerial functions, and increases multitasking. The change in work structure places greater demands on workers who are able to work in teams, adept to communicate effectively, and who are capable of influencing and coaching colleagues and subordinates. Because skill-biased organizational change also implies an increasing demand for workers who are able to run complex organisations, one could expect an increase in the demand for managerial skills.

A number of studies have focussed on the changing returns to interpersonal and managerial skills (related to direction and control). Borghans et al. (2008) distinguish between different interpersonal styles, namely, directness and caring. While directness facilitates accurate communication, caring is required to create a cooperative environment in which tasks have to be carried out. For example, teachers and nurses have to be relatively caring, while salespeople and managers need to be more direct in their interactions with other people. Borghans et al. (2008) demonstrate that directness yields a higher wage premium than caring and that the premium to directness has increased relative to caring in Britain (data covering 1997-2001) and Germany (data covering 19791998). In line with these findings, Autor et al. (2003) document that the returns to interpersonal and managerial skills rose during the 1980s and the 1990s in the United States. Weinberger (2014) finds that the leadership premium, which is measured by whether graduates participated in sports or in high school leadership activities, more than doubled from 1979 to 1999. Finally, Edin et al. (2017) report that the increasing returns to interpersonal skills between 1992-2013 in Sweden was particularly pronounced at the upper-end of the wage distribution. Many of the managerial, professional and technical occupations can be found in the higher end of the wage distribution. Prior research suggests that if interpersonal skills have become more important over time in the

58 The introduction of information technology reduces the cost of decreasing direct control of workers as it allows for indirect, computer-based monitoring of ex post performance. This induces organisational change. Moreover, it also reduces the cost of lateral communication among line workers. Hence, information technology reduces the benefit of hierarchical decision making, thus increasing the incentives for firms to decentralize authority. 
Netherlands, that the reward for such skills will be particularly pronounced in the upperpart of the skill-distribution.

\subsection{Data}

The analyses in this chapter are based on combined data from three different sources; the European Labour Force Survey (EU-LFS), O*NET, and administrative data from Statistics Netherlands. The data cover the period 2001-2016.

\subsubsection{European Labour Force Survey}

The starting point for our database is the EU-LFS for the Netherlands. The EU-LFS is a rotating random sample survey that covers the population in private households in 33 European countries, including the 28 Member States of the European Union. The aim of the EU-LFS is to provide cross-country comparable information in the labour market participation of individuals aged 15 years and above. Since 1999, the EU-LFS is designed as a quarterly rotating panel including five waves. Every month, a sample of addresses is drawn in order to construct a new first wave. By the end of each wave, respondents are approached to participate in the successive wave. The period in between each wave is approximately 3 months and the total period in which individuals participate in the EULFS surveys covers twelve months. ${ }^{59}$ Between 2001 and 2016, 115,563 unique individuals participated on average in the survey each year in the Netherlands.

We use the EU-LFS to derive information on the occupation in which individuals work, namely, the International Standard Classification of Occupations (ISCO-08) code. The 4digit ISCO-08 code is available for workers' main job (i.e. the job with the highest weekly working hours). For our analyses, we use the ISCO-08 of workers' main job in the first wave. The EU-LFS also provides information on workers' highest attained level of education. ${ }^{60}$

\footnotetext{
${ }^{59}$ In the Netherlands, the interviews in the first wave are either conducted through face-to-face interviews or through telephone interviews. Until 2010, data were exclusively collected through faceto-face interviews in the first wave. The data collection in the second through fifth wave takes place by means of telephone interviews.

${ }^{60}$ The levels of education are measured according to the International Standard Classification of Education (ISCED): pre-primary education (ISCED level 0), primary education (ISCED level 1), lower secondary education (ISCED level 2), upper secondary education (ISCED level 3), postsecondary non-tertiary education (ISCED level 4), first stage of tertiary education (ISCED level 5), or second stage of tertiary education (ISCED level 6).
} 


\subsubsection{Occupational Information Network (O*NET)}

The skill requirements measures for occupations are obtained from O*NET. ${ }^{61}$ O*NET is a systematic source of information on occupational characteristics produced by the United States Department of Labor. O*NET introduced its first version in 1998 and started full-scale data collection in 2001. The O*NET database is updated periodically and includes 239 items on abilities, skills, knowledge, and work activities required in an occupation. The measures are mainly derived from job incumbent questionnaires, but also from questionnaires assigned to job analysts. O*NET publishes information at the level of occupations. A description of the data collection method can be found in Appendix 6.1.

We closely follow Acemoglu and Autor (2011) in measuring the use of non-routine cognitive analytical skills and non-routine cognitive interpersonal skills in occupations. We measure analytical skills as the average of the following three questions: (i) "how important is analysing data or information to the performance of your current job?", (ii) "how important is thinking creatively to the performance of your current job?", and (iii) "how important is interpreting the meaning of information for others to the performance of your current job?". The average of the following questions is taken to obtain a measure of interpersonal skills: (i) "how important is establishing and maintaining interpersonal relationships to the performance of your current job?", (ii) "how important is guiding, directing, and motivating subordinates to the performance of your current job?", and (iii) "how important is coaching and developing others to the performance of your current job?". Job incumbents indicate the importance of each item on an ordinal scale from 1-5 $(1=$ not important, $5=$ extremely important). The Cronbach's alpha scale reliability coefficients are 0.8196 for non-routine analytical skills and 0.8176 for non-routine interpersonal skills. All items are derived from the O*NET Work Activities Survey Version 21.1.

The occupational classification of $\mathrm{O}^{*} \mathrm{NET}(\mathrm{O} * \mathrm{NET} 2010-\mathrm{SOC}$ ) is mapped to the ISCO08 classification. O*NET Version 21.1 provides occupational characteristics of 964 different occupations in the United States. The mapping between the O*NET 2010-SOC and the ISCO-08 classification is facilitated by a crosswalk file that maps each O*NET code to the corresponding ISCO-08 occupation. ${ }^{62}$ In total, there are 1,110 O*NET SOC2010 occupations and 436 ISCO-08 occupations, making the O*NET classification more detailed than the ISCO-08. The analytical and interpersonal skill variables, measured at

\footnotetext{
${ }^{61} \mathrm{O}^{*}$ NET is the successor of the Dictionary of Occupational Titles (DOT).

62 The crosswalk is available on http://ibs.org.pl/en/resources/occupation-classificationscrosswalks-from-onet-soc-to-isco/.
} 
the level of O*NET SOC occupations, are collapsed to the ISCO-08 occupations weighted by US employment in each SOC cell. The vector of the two skills, $S_{j}^{(x)}$, where the measure of each skill, $S^{(x)}$, for each ISCO-08 4-digit occupation $j=1, \ldots I$ is computed as:

$$
S_{j}^{(x)}=\sum_{\substack{k=1 \\ k \in\left\{S_{j}\right\}}}^{K_{j}} O_{k}^{(x)} \frac{n_{k}}{\sum_{k} n_{k}}
$$

Here, $O_{k}^{(x)}$ represents the measure of skill $x$ for O*NET SOC occupation $k$. The number of employed individuals in occupation $k$ is derived from the US Occupational Employment Statistics (OES) ${ }^{63}$ and is represented by $n_{k}$, while $\Sigma_{k} n_{k}$ indicates total employment across all occupations $k$. The summation is over the set $k \in\left\{S_{j}\right\}$ of the $K_{j}$ O*NET SOC occupations that are matched to ISCO-08 4-digit occupation $j$. The importance scores are normalized to have a mean of 0 and a standard deviation of 1 within each year.

\subsubsection{Statistics Netherlands}

Information on workers' wages is retrieved from administrative data from Statistics Netherlands. ${ }^{64}$ For each separate job a worker holds in a specific year, we observe the gross annual wage including national insurance contributions, the number of days a worker has been employed, and the full-time equivalent for which workers are employed. To calculate the number of full-time days an individual has worked in a specific job, we multiply the number of days a worker has been employed in a specific job by the full-time equivalent. We then calculate for each worker's job the gross daily wage by dividing the gross annual wage by the number of full-time days worked. ${ }^{65}$ In the case that workers have multiple jobs in a specific year, we calculate the average gross daily salary across those jobs. The wages are indexed to 2015 euros. ${ }^{66}$ The data from Statistics Netherlands also include information on the firm size ${ }^{67}$, and on worker's gender, age, and migration

\footnotetext{
${ }^{63}$ The OES employment data can be retrieved from https://www.bls.gov/oes/tables.htm.

${ }^{64}$ Quantitative information concerning jobs is retrieved from the dataset BAANSOMMENTAB. Statistics Netherlands also provides wage data in the POLISBUS dataset. However, the data is only available for the period 2006-2017. BAANSOMMENTAB provides wage data for the period 19992016.

${ }^{65}$ Although we do observe workers' yearly income tax and yearly income tax allowance, we prefer to use workers' gross wages rather than net wages. To calculate the net wages correctly, we would also needs information on expenses that are tax deductible.

${ }^{66}$ We use the consumer price index from Statistics Netherlands.

${ }^{67}$ Qualitative information of jobs are obtained from the dataset BAANKENMERKENBUS. This dataset provides us with an employer identification number which is matched to the dataset BETAB which provides information on the firm size. In the case that workers hold more than one job in a
} 
background. ${ }^{68}$ Although Statistics Netherlands also offers administrative data on the highest attained level of education, the data are only available for persons who obtained their degree after 2000. For this reason, we use self-reported attained levels of education from the EU-LFS data.

To obtain the best estimates of lifetime returns to skills, the sample is restricted to primeage workers, defined as workers aged between 35 and 54 years (Böhlmark \& Lindquist, 2006; Haider \& Solon, 2006). Given that workers with high lifetime earnings tend to have steep earnings trajectories, focussing on earnings observed in the early stage of workers' careers is likely to provide a biased estimate of lifetime earnings. We trim the bottom and top one percent of the wage distribution to limit the influence of wage outliers. Table 6.1 shows the number of observations available for each year in our dataset.

Table 6.2 shows how skill requirements are distributed across a broader classification of occupational groups, namely, 39 sub-major groups (2-digit ISCO occupations). ${ }^{69}$ Analytical skills are particularly important for the ISCO major group "Professionals" which include the sub-major groups "Science and Engineering Professionals", "Health Professionals", as well as "ICT Professionals". ${ }^{70}$ According to the O*NET measures, occupations in the ISCO major group "Managers" also score relatively high on analytical skill requirements. The O*NET skill measures are consistent with the Skill Level that ISCO assigns to the majority of the occupations in these two major groups, namely, Skill Level 4 (i.e. the highest Skill Level). Within the major group "Managers", ISCO only assigns Skill Level 3 to the sub-major group "Hospitality, Retail and other Services Managers". Occupations at Skill Level 4 generally consist of tasks that require complex problem-solving skills, decision-making skills and creativity and the application of a large body of theoretical and factual knowledge in a specialized field. Occupations at Skill Level 4 typically require high levels of literacy and numeracy as well as excellent interpersonal communication skills. According to the O*NET skill measures, the major groups "Managers" and "Professionals" require extended levels of interpersonal skills. Similarly, ISCO indicates that occupations at Skill Level 4 require excellent interpersonal

specific year, we use qualitative information for the job in which a person was employed for the most number of days which is based on the number of days between the start and end date of a job.

${ }^{68}$ Demographic information is obtained from the dataset GBAPERSOONTAB.

${ }^{69}$ In total, ISCO distinguishes between 43 2-digit major groups. O*NET provides no skill measures for the three Armed Forces Occupational groups and the Subsistence Farmers, Fishers, Hunters and Gatherers occupational group.

70 ISCO distinguishes between 10 1-digit major groups, namely, managers (1), professionals (2), technicians and associate professionals (3), clerical support workers (4), services and sales workers (5), skilled agricultural, forestry and fishery workers (6), craft and related trades workers (7), plant and machine operators, and assemblers (8), elementary occupations (9), and armed forces occupations (0). ISCO distinguishes between 43 2-digit sub-major groups, 130 3-digit minor groups, and 436 4-digit unit groups. 
communication skills. The high level of interpersonal skills assigned to managerial occupations does not necessarily reflect that interpersonal skills are less important in, for example, low-paid service occupations. However, the nature of the interpersonal skills required in managerial functions might differ from those required in service occupations. The measure used for interpersonal skills in this study rather relate to the guidance and supervision of subordinates in the workplace.

\section{Table 6.1: Data availability}

\begin{tabular}{lc}
\hline \hline Year & Total number of observations \\
\hline 2001 & 19,083 \\
2002 & 19,934 \\
2003 & 20,666 \\
2004 & 23,649 \\
2005 & 22,554 \\
2006 & 17,983 \\
2007 & 17,652 \\
2008 & 18,070 \\
2009 & 14,868 \\
2010 & 22,178 \\
2011 & 15,582 \\
2012 & 11,070 \\
2013 & 32,272 \\
2014 & 19,716 \\
2015 & 20,342 \\
2016 & 18,583 \\
\hline \hline
\end{tabular}

Occupations in which non-routine analytical and interpersonal skills are evidently less important according to O*NET are occupations in the ISCO major groups "Plant and Machine Operators and Assemblers" and "Elementary Occupations". Most occupations in the major group "Elementary Occupations" require skills at the first ISCO skill level for the duties and tasks involved in an occupation. According to ISCO, some occupations at Skill Level 1 require basic numeracy and literacy skills. "Elementary Occupations" involve the performance of simple and routine physical or manual tasks. To adequately perform the tasks in most occupations in the ISCO major group "Plant and Machine Operators and Assemblers", skills at the second ISCO level are required. For the majority of occupations requiring ISCO Skill Level 2, workers need to have the ability read, write, and to accurately perform simple arithmetical calculations. Analytical and interpersonal skills are also less important in the ISCO major group "Skilled Agricultural, Forestry and Fishery Workers". 
Table 6.2: Descriptive statistics

\begin{tabular}{|c|c|c|c|c|c|c|c|c|}
\hline Occupational group & $\begin{array}{c}\text { ISCO } \\
\text { code }\end{array}$ & $\begin{array}{l}\text { Employment } \\
\text { share in hours } \\
\text { in } 2001(\%)\end{array}$ & $\begin{array}{l}\text { Employment } \\
\text { share in hours } \\
\text { in } 2016(\%)\end{array}$ & $\begin{array}{c}\text { Employment } \\
\text { share } 2001-2016 \\
\text { (\%-points) }\end{array}$ & $\begin{array}{l}\text { Analytical } \\
\text { skill } \\
\text { importance }\end{array}$ & $\begin{array}{l}\text { Interpersonal } \\
\text { skill } \\
\text { importance }\end{array}$ & $\begin{array}{c}\text { ISCO } \\
\text { skill } \\
\text { level }\end{array}$ & $\begin{array}{c}\text { Gross } \\
\text { daily } \\
\text { wage }\end{array}$ \\
\hline Chief Executives, Senior officials and Legislators & 11 & 1.98 & 2.28 & 0.30 & 0.96 & 1.99 & $3+4$ & 205.93 \\
\hline Administrative and Commercial Managers & 12 & 1.74 & 2.46 & 0.73 & 1.47 & 1.81 & $3+4$ & 200.44 \\
\hline Production and Specialized Services Managers & 13 & 5.57 & 3.41 & -2.16 & 1.25 & 1.80 & $3+4$ & 180.8 \\
\hline Hospitality, Retail and Other Services Managers & 14 & 1.80 & 1.26 & -0.54 & 0.79 & 1.91 & $3+4$ & 143.73 \\
\hline Science and Engineering Professionals & 21 & 2.40 & 2.49 & 0.08 & 1.72 & 0.46 & 4 & 160.27 \\
\hline Health Professionals & 22 & 2.62 & 3.07 & 0.45 & 1.42 & 1.29 & 4 & 152.77 \\
\hline Teaching Professionals & 23 & 4.39 & 6.26 & 1.87 & 1.19 & 1.49 & 4 & 142.55 \\
\hline Business and Administration Professionals & 24 & 4.58 & 10.53 & 5.95 & 1.58 & 0.96 & 4 & 168.32 \\
\hline Information and Communications Technology Professionals & 25 & 0.62 & 3.83 & 3.21 & 1.56 & 0.30 & 4 & 169.03 \\
\hline Legal, Social and Cultural Professionals & 26 & 3.22 & 3.26 & 0.04 & 1.45 & 0.20 & 4 & 153.51 \\
\hline Science and Engineering Associate Professionals & 31 & 6.73 & 3.27 & -3.47 & 0.26 & 0.15 & 3 & 136.25 \\
\hline Health Associate Professionals & 32 & 3.15 & 3.30 & 0.15 & 0.61 & 0.70 & 3 & 108.37 \\
\hline Business and Administration Associate Professionals & 33 & 8.89 & 9.19 & 0.30 & 0.45 & -0.03 & 3 & 138.64 \\
\hline Legal, Social, Cultural and Related Associate Professionals & 34 & 1.95 & 1.95 & -0.01 & -0.03 & 0.03 & 3 & 102.51 \\
\hline Information and Communications Technicians & 35 & 0.10 & 0.61 & 0.51 & 0.61 & -0.76 & 3 & 126.34 \\
\hline General and Keyboard Clerks & 41 & 3.41 & 2.54 & -0.87 & -0.66 & -1.09 & 2 & 96.58 \\
\hline Customer Services Clerks & 42 & 1.00 & 2.16 & 1.16 & -0.41 & -0.35 & 2 & 97.97 \\
\hline Numerical and Material Recording Clerks & 43 & 3.07 & 5.42 & 2.34 & -0.12 & -0.72 & 2 & 116.52 \\
\hline Other Clerical Support Workers & 44 & 1.80 & 1.24 & -0.57 & -1.06 & -1.35 & 2 & 92.03 \\
\hline Personal Services Workers & 51 & 2.26 & 2.81 & 0.55 & -0.96 & -0.24 & & 92.06 \\
\hline Sales Workers & 52 & 5.18 & 5.38 & 0.19 & -0.10 & 0.03 & & 96.62 \\
\hline Personal Care Workers & 53 & 1.58 & 3.40 & 1.81 & -0.29 & 0.17 & & 83.09 \\
\hline Protective Services Workers & 54 & 1.70 & 1.43 & -0.27 & 0.50 & 0.98 & & 113.09 \\
\hline
\end{tabular}


Table 6.2 (continued)

\begin{tabular}{|c|c|c|c|c|c|c|c|c|}
\hline Occupational group & $\begin{array}{l}\text { ISCO } \\
\text { code }\end{array}$ & $\begin{array}{c}\text { Employment } \\
\text { share in hours in } \\
2001(\%)\end{array}$ & $\begin{array}{c}\text { Employment } \\
\text { share in hours in } \\
2016(\%)\end{array}$ & $\begin{array}{c}\text { Employment } \\
\text { share } 2001-2016 \\
\text { (\%-points) }\end{array}$ & $\begin{array}{l}\text { Analytical } \\
\text { skill } \\
\text { importance }\end{array}$ & $\begin{array}{l}\text { Interpersonal } \\
\text { skill } \\
\text { importance }\end{array}$ & $\begin{array}{l}\text { ISCO } \\
\text { skill } \\
\text { level }\end{array}$ & $\begin{array}{l}\text { Gross } \\
\text { daily } \\
\text { wage }\end{array}$ \\
\hline Market-oriented Skilled Agricultural Workers & 61 & 2.23 & 1.11 & -1.12 & -0.55 & 0.37 & & 88.82 \\
\hline $\begin{array}{l}\text { Market-oriented Skilled Forestry, Fishery and } \\
\text { Hunting workers }\end{array}$ & 62 & 0.09 & 0.02 & -0.06 & -0.11 & 0.42 & & 116.2 \\
\hline Metal, Machinery and Related Trades Workers & 72 & 4.89 & 2.65 & -2.24 & -0.34 & -0.60 & & 105.20 \\
\hline Handicraft and Printing Workers & 73 & 1.05 & 0.35 & -0.69 & 0.10 & -1.34 & & 101.00 \\
\hline Electrical and Electronic Trades Workers & 74 & 1.77 & 0.85 & -0.92 & 0.19 & 0.16 & & 109.75 \\
\hline $\begin{array}{l}\text { Food Processing, Woodworking, Garment and } \\
\text { Other Craft and Related Trades Workers }\end{array}$ & 75 & 1.84 & 1.07 & -0.77 & -1.04 & -1.39 & & 92.41 \\
\hline Stationary Plant and Machine Operators & 81 & 2.08 & 0.92 & -1.16 & -0.62 & -0.75 & & 100.70 \\
\hline Assemblers & 82 & 0.52 & 0.28 & -0.24 & -0.52 & -0.67 & & 87.62 \\
\hline Drivers and Mobile Plant Operators & 83 & 6.10 & 3.49 & -2.61 & -0.33 & -0.64 & & 105.27 \\
\hline Cleaners and Helpers & 91 & 0.50 & 1.88 & 1.39 & -1.51 & -1.22 & & 71.32 \\
\hline Agricultural, Forestry and Fishery Labourers & 92 & 0.13 & 0.12 & -0.01 & -1.53 & -1.17 & 1 & 76.53 \\
\hline $\begin{array}{l}\text { Labourers in Mining, Construction, } \\
\text { Manufacturing and Transport }\end{array}$ & 93 & 3.19 & 2.33 & -0.86 & -1.24 & -1.01 & 1 & 84.18 \\
\hline Food Preparation Assistants & 94 & 0.42 & 0.20 & -0.23 & -1.54 & -0.71 & 1 & 73.06 \\
\hline Street and Related Sales and Services Workers & 95 & 0.01 & & & -1.55 & 0.46 & 1 & 118.24 \\
\hline Refuse Workers and Other Elementary Workers & 96 & 0.13 & 0127 & 0.14 & -1.42 & -1.57 & 1 & 84.98 \\
\hline
\end{tabular}

Notes: The analytical sand interpersonal skill importance measures have a mean of 0 and a standard deviation of 1 . The wages are indexed to 2015 euros. The skill importance measures and gross daily wages are calculated as the average of the underlying 4-digit ISCO occupations weighted by the share of hours worked. The skill level is defined by ISCO as a function of the complexity and range of tasks to be performed in an occupational group. Occupations at Skill Level 1 generally require basic literacy and numeracy skills. Occupations at Skill Level 2 generally require relatively advanced literacy and numeracy skills and good interpersonal communication skills. Occupations at Skill Level 3 generally require a high level of literacy, numeracy and interpersonal communication skills. Occupations at Skill Level 4 generally require extended levels of literacy and numeracy, sometimes at a very high level, and excellent interpersonal communication skills. 
From Table 6.2, it can also be observed that positive employment growth, expressed in hours worked, is mostly observed in occupations in which non-routine analytical skills and non-routine interpersonal skills are relatively important. For example, an occupational group that has more than doubled in terms of its employment share between 2001 and 2016 is the sub-major group "Business and Administration Professionals". This sub-major group also requires one of the highest levels of analytical skills and a relatively high level of interpersonal skills. The employment share of the submajor group "Stationary Plant and Machine Operators" more than halved between 2001 and 2016. This sub-major group requires relatively low levels of analytical and interpersonal skills. Finally, Table 6.2 also shows that occupations that are intensive in analytical and interpersonal skills are associated with a higher gross daily wage.

\subsection{Empirical model}

We estimate the wage return to non-routine analytical skills and non-routine interpersonal skills at successive points in time. We estimate wage regressions of the following kind:

$$
\log \left(\text { wage }_{i t}\right)=\beta_{0}+\beta_{1 t} \text { Analytical }_{j}+\beta_{2 t} \text { Interpersonal }_{j}+\gamma_{t} X_{i}+\varepsilon_{i j}
$$

where wage $_{i}$ indexes the gross daily wage of individual $i$ in year $t$, and Analytical and Interpersonal denote the importance of non-routine cognitive skills and non-routine interpersonal skills, respectively, in occupation $j$. The model includes a vector of controls $X$, including gender, ethnicity, the highest attained level of education, age, age squared, and the firm size in which person $i$ is employed. The standard errors are clustered at the level of the 4-digit ISCO occupation. The regressions are run separately for each year between 2001-2016. The coefficient of interest, $\beta_{1}\left(\beta_{2}\right)$ can be interpreted as the wage premium associated with analytical (interpersonal) skills used in jobs, conditional on interpersonal (analytical) skills.

The OLS estimates will not reflect the true value of $\beta_{1}$ and $\beta_{2}$ when (a) workers do not actually possess the skills that are required in their occupation (a situation of skill mismatch) and (b) when the acquisition of skills is endogenously determined (such that Analytical, Interpersonal and $\varepsilon$ are not orthogonal). Because additional skills or schooling can increase productivity, over-skilled workers might incur a wage premium over their well-matched colleagues (e.g. Quintini, 2011a; Rumberger, 1987). Hence, a situation of over-skilling will lead to an upper-bound estimate of the true skill rewards (i.e. a situation in which workers' skills match the requirements of the job). In contrast, if under-skilled workers are less productive than their well-matched colleagues, a situation 
of under-skilling will result in a lower-bound estimate of the true value of $\beta_{1}$ and $\beta_{2}$ (Quintini, 2011a). Because under-skilling is a phenomenon that occurs less frequently than over-skilling in most countries (Pellizari \& Fichen, 2013), including the Netherlands, we expect $\beta_{1}$ and $\beta_{2}$ to reflect upper-bound estimates of the true skill premiums. Nevertheless, we expect the upward bias of our estimates to be limited for two reasons. First, the incidence of over-schooling in the Netherlands has been rather low during our sample period (ILO, 2014). Second, while over-skilled workers can receive a wage premium over their well-matched colleagues, excess skills or schooling do not always translate into raised productivity and therefore will not always be rewarded with higher earnings (Gautier et al., 2002; Rumberger, 1987; Van der Velden \& Bijlsma, 2018).

Identifying a causal relationship between a given increase in workers' skills and earnings, also requires the observed variation in skill requirements across workers' occupations to be truly exogenous. There are several potential threats to causal identification of this relationship. First, omitted variables could lead to classic omitted variable bias if they are related to skills and also directly influence earnings (e.g. family background, ability, or personality traits). For example, if family background influences skill endowment and development and if family ties also help individuals to find better jobs, the relation between skills and earnings will not merely reflect the causal effect of skills. It is important to note that the potential bias that results from omitted variables does not regard the typical 'ability bias' that is the focus of attention in the extensive literature on causal estimates of the returns to schooling. Hence, we acknowledge that the skills applied in jobs can either emerge from innate abilities, the home environment, but also from investments in schooling. The second threat to causal identification is one of reversed causality; better paying jobs might provide more opportunities for skill development through on the job training or by investments in adult education. These occupations might also have higher skill requirements. Because our data are not rich enough to identify exogenous variation in workers' skills and assignment to occupations, we rely on time series estimates of the premiums associated with different skill types. Under the assumption that the magnitude of any form of bias remains constant over time, changes that are observed in skill rewards will reflect a shift in the interaction between the demand and supply of non-routine skills. 


\subsection{The returns to analytical and interpersonal skills}

The estimates of the conditional returns to analytical and interpersonal skills for the entire labour market (both public and private sector workers) are plotted separately in Figure 6.1. ${ }^{71}$ Between the early 2000s and the mid 2010s, the reward for analytical skills increased from 9.4 percent in 2001 to 16.0 percent in 2016. In 2016, a person employed in a job requiring one standard deviation more analytical skills than the mean for all occupations received a gross daily wage that was 16.0 percent higher than in jobs requiring the mean. The return to interpersonal skills slightly decreased over the past two decades from 3.3 percent in 2001 to 0.8 percent in 2016.

Given that the skill rewards in the private sector are typically driven by market forces, the skill premiums in the private sector might be a better reflection of the actual demand for skills. To test this, we restrict the sample to private sector workers. Figure 6.2 shows that the estimates for the private sector are very similar. The return to analytical skills increased from 8.1 percent in 2001 to 16.4 percent in 2016 in the private sector. The conditional return to interpersonal skills declined from 4.5 percent in 2001 to 1.6 percent in 2016. Because the estimates of the returns to both skill components are similar for the overall labour market as well as for the private sector workers only, we proceed with the sample including both the private and public sector workers in the subsequent analyses.

\subsection{Non-linearities in the return to skills}

In this section we examine whether the trends in the return to analytical and interpersonal skills are driven by a specific segment of the wage distribution. If technology has substituted for workers in the middle of the skill distribution, as predicted by the job polarization hypothesis, greater employment growth will be observed at the lower and upper end of the skill distribution (Goos et al., 2014). However, while some of the tasks that are part of many occupations in the middle of the skill distribution are susceptible to automation, many middle skill occupations consist of a mixture of tasks requiring a different set of skills. For example, electrical and installation technicians constitute a rapidly growing category of relatively well-remunerated, middle-skill employment. While electrical and installation technicians are not required to possess a higher education degree, they are expected to master a 'middle-skill' level of analytical skills. If tasks are difficult to unbundle, machines will perform routine tasks while workers will continue to perform the set of non-routine tasks in which they hold a comparative advantage.

71 The estimates for the sample that is restricted to workers in full-time jobs are presented in Appendix 6.2. The results are qualitatively comparable to the sample consisting of workers in fulltime as well as part-time jobs. 
Figure 6.1: The returns to analytical and interpersonal skills

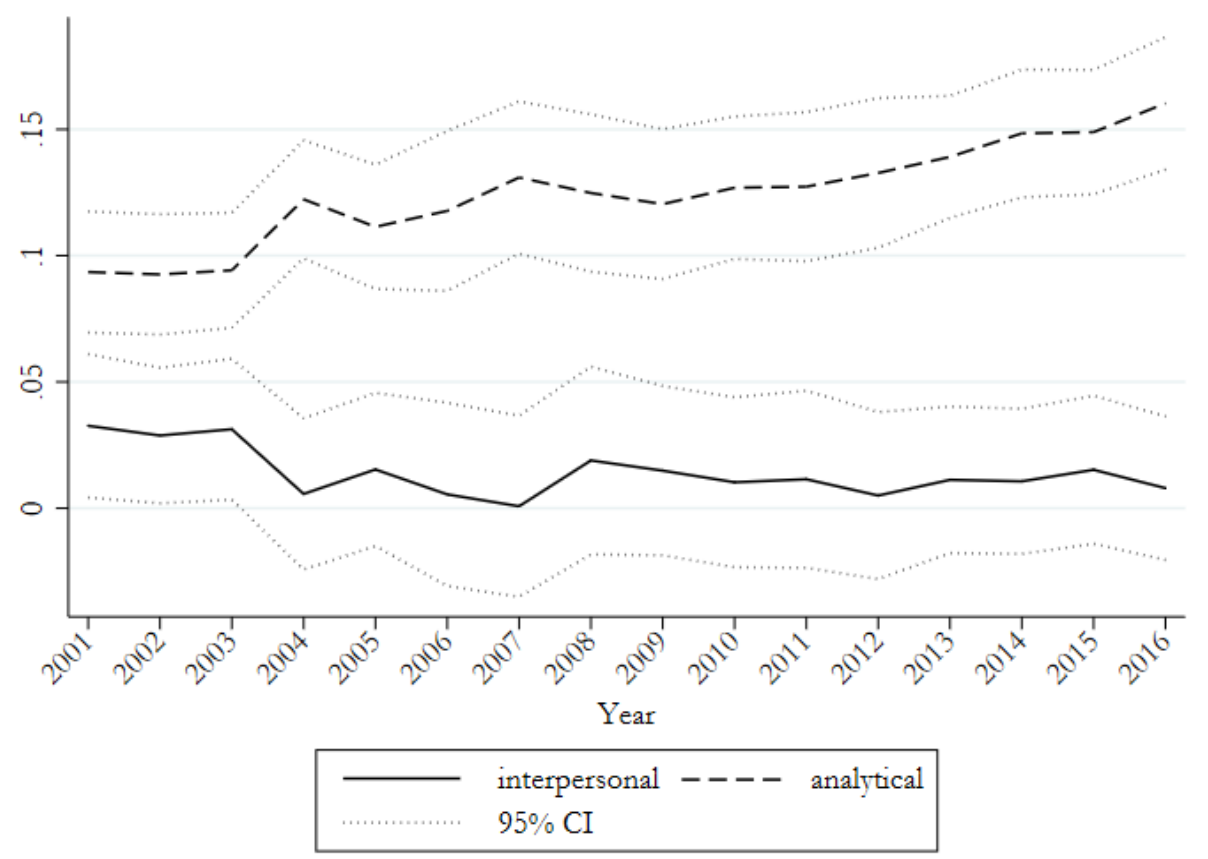

Notes: The lines represent the estimated regression coefficients for each year using specification (1).

Figure 6.2: The returns to analytical and interpersonal skills - Private sector workers

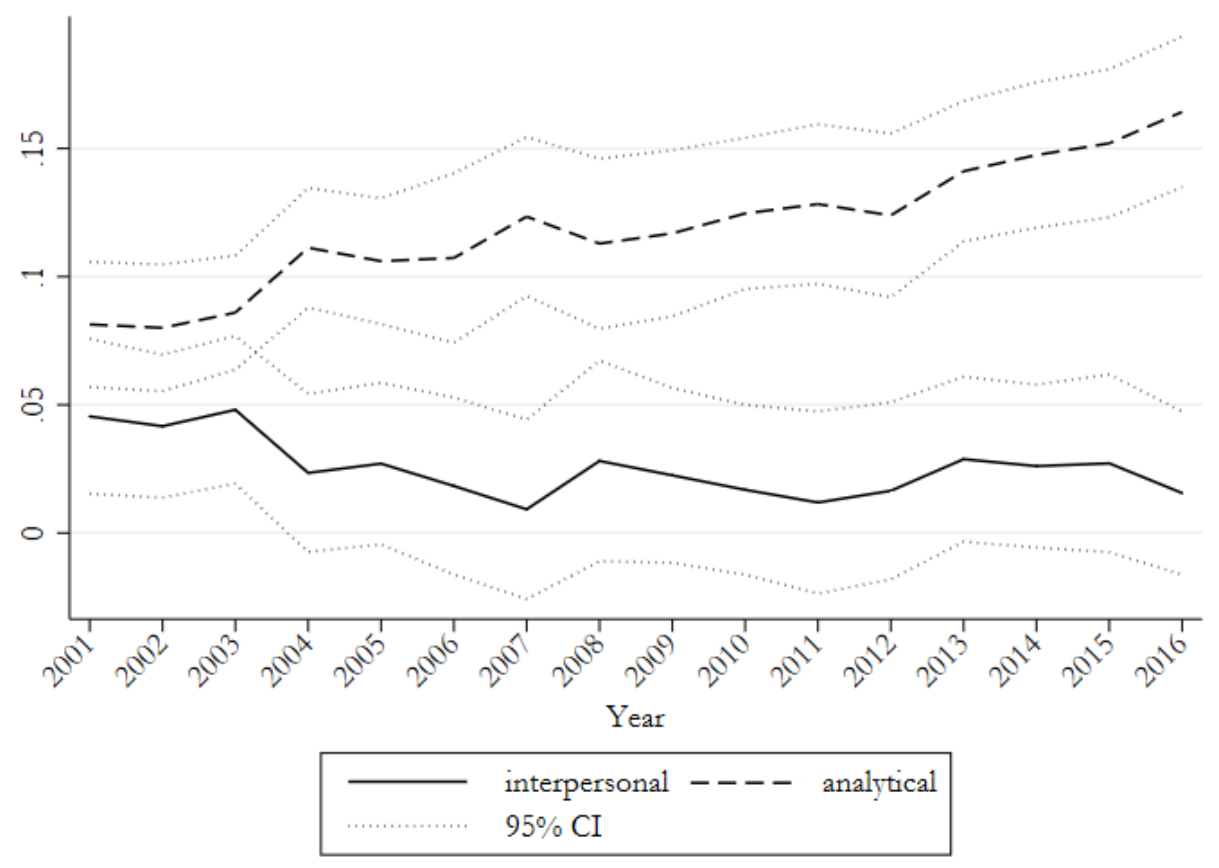

Notes: The lines represent the estimated regression coefficients for each year using specification (1). 
To analyse whether the return to skills are non-linear or not, we estimate quantile regressions corresponding to Equation (1). Figure 6.3 presents the quantile regressions estimates for non-routine analytical skills and Figure 6.4 shows the estimates for nonroutine interpersonal skills. Figure 6.3 suggests that the return to analytical skills strongly increased in all parts of the wage distribution. In 2001, the wage premium for analytical skills was 11.4 percent in the lower end of the wage distribution (the $10^{\text {th }}$ percentile and below) and 9.2 percent in the middle part of the wage distribution (at the $50^{\text {th }}$ percentile). By 2016, the wage premium had grown to 15.6 percent in the lower end of the wage distribution and to 16.2 percent in the middle of the wage distribution. In the upper-end of the wage distribution (from the $90^{\text {th }}$ percentile and above), the return to analytical skills increased from 8.0 percent in 2001 to 17.8 percent in 2016.

The highest wage premium for interpersonal skills is observed in the upper-end of the wage distribution (from the $90^{\text {th }}$ percentile and above). In 2001, a one standard deviation increase in interpersonal skills is associated with being employed in an occupation that offers 4.7 percent higher wages. In 2016, this premium declined to 2.0 percent for the upper-end of the wage distribution. For the lower end of the wage distribution (from the $10^{\text {th }}$ percentile and below), being employed in a job that requires a one standard deviation higher level of interpersonal skills compared to the mean, is associated with a wage premium of 2.6 percent in 2001 and -0.1 percent in 2016 for the lower end of the wage distribution. In the middle part of the wage distribution, the returns to interpersonal skills decreased from 2.5 percent in 2001 to -0.01 percent in 2016.

When the sample is restricted to full-time workers, we observe a slight increase in the reward for interpersonal skills (results presented in Appendix 6.2). In 2001, the premium for interpersonal skills yielded 3.7 percent for the overall sample which increased to 4.0 percent in 2016. The upward trend in the returns to interpersonal skills is most pronounced for workers in the upper-end of the wage distribution where the premium for interpersonal skills rose from 5.8 percent in 2001 to 7.4 percent in 2016. In the middle part of the wage distribution, the interpersonal skills premium increased from 2.1 percent in 2001 to 2.8 in 2016. The increasing trend appears to be absent in the lowerend of the wage distribution where the return yielded 1.7 percent in 2001 and 1.8 percent in 2016. 
Figure 6.3: The returns to analytical skills: quantile regression estimates

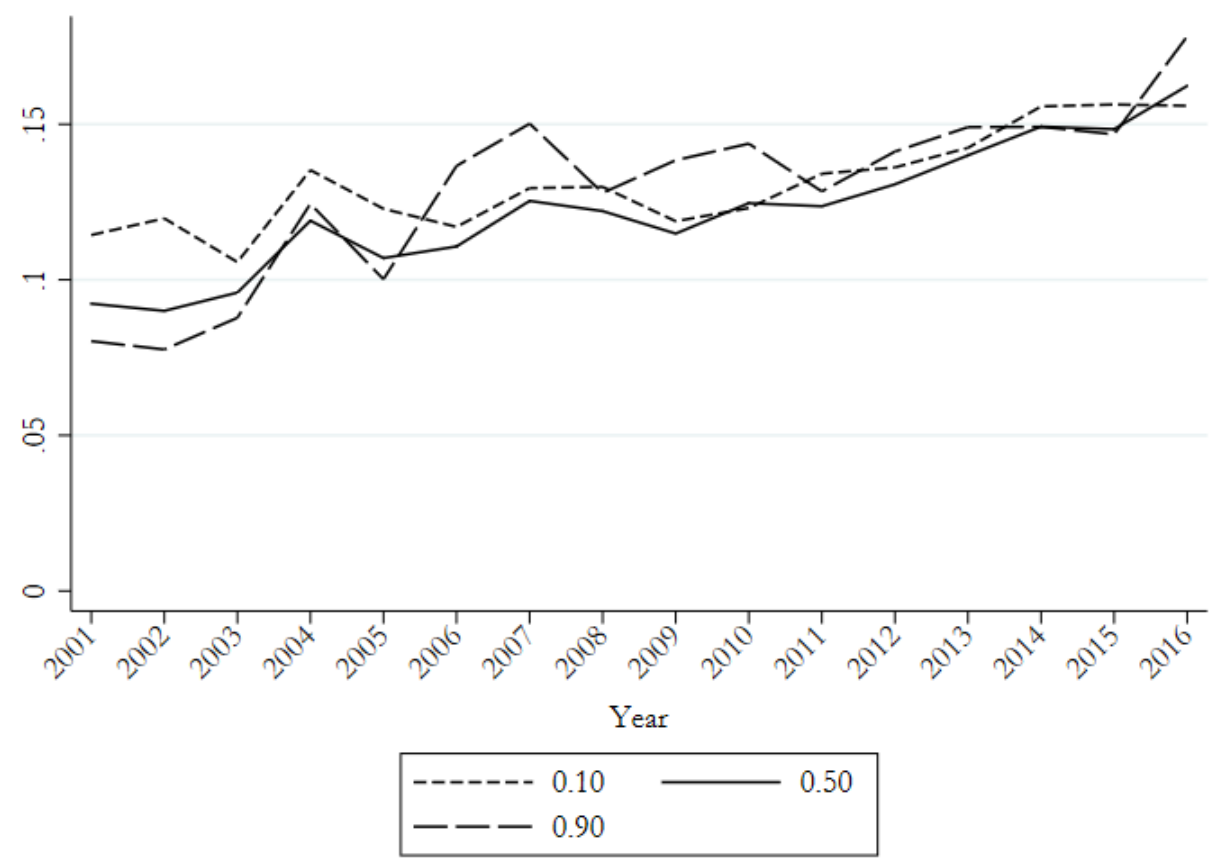

Notes: The lines represent the estimated regression coefficients for each year using specification (1).

Figure 6.4: The returns to interpersonal skills: quantile regression estimates

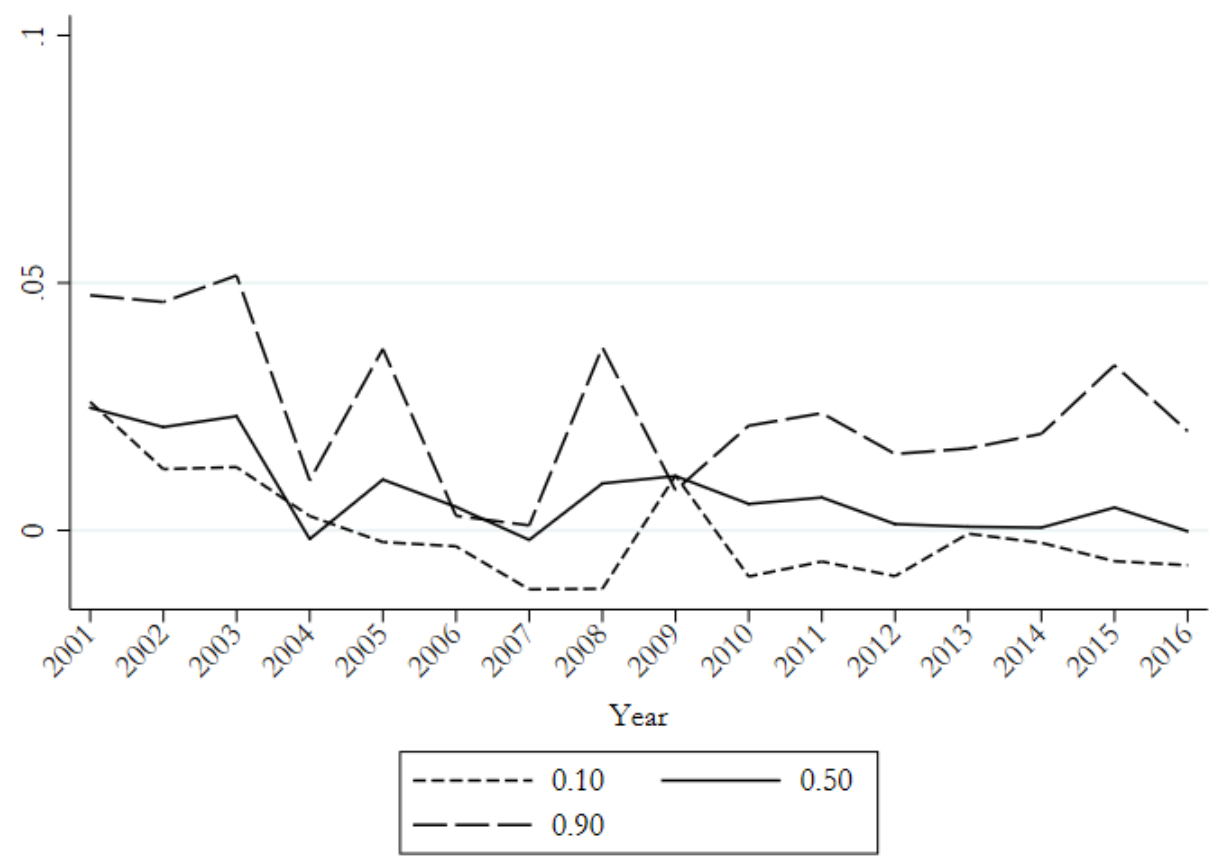

Notes: The lines represent the estimated regression coefficients for each year using specification (1). 
The estimates are consistent with Deming (2017) who reports an increase in the return to interpersonal skills for full-time workers in the United States between 1980-2012. In addition, the findings are also in line with Edin et al. (2017) who document that the increasing reward for interpersonal skills in Sweden is particularly pronounced at the upper-end of the wage distribution. Deming (2017) documents that workers who possess a high level of interpersonal skills were increasingly likely to select themselves into fulltime employment. Hence, our findings could reflect an increasing demand for workers in managerial jobs that are intensive in interpersonal skills and that are typically full-time positions. The constant returns to interpersonal skills for workers in the lower-end of the wage distribution is consistent with previous empirical findings indicating that high-skill occupations exhibit a greater employment increase than low-skill service jobs in the Netherlands (OECD, 2016; Terzidis, Maarseveen \& Ortega-Argilés, 2017).

\subsection{Conclusion and discussion}

While skills are an increasingly important predictor of graduates' labour market success, empirical evidence on how skills are rewarded in the labour market almost exclusively rely on school attainment measures of human capital. This study investigates trends in the returns to non-routine cognitive analytical and non-routine cognitive interpersonal skills between 2001 and 2016 in the Netherlands. Given that only imperfect measures of the skills used in employment today are available for the Netherlands, we construct occupational skill profiles by matching skill measures from the US O*NET system to the occupations of Dutch workers. These data are combined with information on employment and wages from administrative data from Statistics Netherlands.

We document an increase in the premium for non-routine analytical skills. For the overall labour market, the reward for analytical skills increased from 9.4 percent in 2001 to 16.0 percent in 2016. An increase in the analytical skill premium is not only observed in the upper-end of the wage distribution (from the $90^{\text {th }}$ percentile and above), but also in the middle- (50th percentile) and lower-end (the $10^{\text {th }}$ percentile and below) of the distribution. Overall, our findings indicate that non-routine analytical skills are increasingly valued on the Dutch labour market. The increasing reward for analytical skills supports the idea that the demand for non-routine tasks (i.e. interpreting and analysing information) have increased as computerization has boosted the productivity of routine tasks (i.e. due to declining costs of retrieving and manipulating information). Our findings propose that workers in all segments of the wage distribution performing nonroutine tasks have benefitted from the increased productivity in routine tasks. The rising premium also suggests that the demand for analytical skills has outpaced the supply of such skills over the past two decades. This makes sense given that the supply of skilled 
labour is rather inelastic. While the stock of workers with vocational or higher education degrees are certainly increasing in the Netherlands, it takes typically at least four years to complete a study programme in upper-secondary or tertiary education and to enter the labour market. Although certain tasks in many middle-skill jobs are susceptible to automation, the increasing return to analytical skills in the middle of the wage distribution indicates that many jobs in this segment will continue to require a changing set of skills. Hence, boosting the development of analytical skills will not only continue to be essential in higher education, but also in study programmes provided by vocational education and training.

With respect to the reward for interpersonal skills, we document a decline from 3.3 percent in 2001 to 0.8 percent in 2016 for the overall sample consisting of full-time and part-time workers. We only find a considerable increase in the reward for interpersonal skills for full-time workers higher up in the wage distribution. For workers in the upperend of the wage distribution (from the $90^{\text {th }}$ percentile and above), the interpersonal skill reward rose from 5.8 percent in 2001 to 7.4 percent in 2016. This finding is consistent with the idea that increased organisational complexity have put greater demands on interpersonal communication and managerial skills (Bresnahan et al., 2002; Caroli \& Van Reenen, 2001). Therefore, the demand for workers in managerial positions might have outpaced the supply of workers possessing good interpersonal and managerial skills. This is consistent with studies reporting that managerial interpersonal skills are increasingly rewarded in the labour market (Autor et al., 2003; Borghans et al., 2007; Weinberger, 2014). Although interpersonal skills are typically also important in service jobs that can be found in lower segments in the wage distribution, the supply for interpersonal skills might have increased at a higher pace than the demand for such skills.

Finally, this study is subject to several limitations. First, O*NET assigns task measures to occupations and, thereby, ignores the heterogeneity in job tasks across individuals holding similar occupations. A number of studies highlight the relevance of withinoccupation variation in tasks (Arntz, Gregory \& Zierahn, 2017; Autor \& Handel, 2013; Cassidy, 2017). Hence, the wage differentials across occupations and the observed changes in the skill premiums over time reported in this study should be attributed to differences in skill requirements across occupations and to developments in the occupational structure. Given that occupations alone do not fully reveal the type of tasks workers execute, future research on the returns to skills ideally relies on skill measures at the individual level of Dutch workers. Such data will also be less prone to measurement error. 
Chapter 6

\section{Appendix 6.1: Data collection O*NET}

The data collection is conducted by identifying industries that comprise occupations that are targeted in a data collection cycle. A random sample of establishments within those industries are approached. Employers who agree to participate are requested to distribute the seven O*NET surveys (Abilities, Knowledge, Skills, Work Activities, Work Context, Work Style, and Education and Training) to a random group of employees who are employed in the targeted occupations. According to estimates, 70 percent of the contacted employers agree to distribute surveys among their employees, of whom 65 percent returned completed surveys (U.S. Department of Labor, 2005, p. A-13, B-28). To avoid fatigue, employees are requested to fill in a subset of the questionnaires which take about half an hour complete.

Although $\mathrm{O}^{*} \mathrm{NET}$ does not publish information on the total sample size, measures in the O*NET database are based on at least 15 respondents per occupation and often many more (U.S. Department of Labor 2005, p. B-6). An O*NET staff member estimated that approximately 125,000 questionnaires were collected from job incumbents in the most recent data collection cycle (Händel, 2016). This implies that each of the 239 measures are based on roughly 31,000 respondents, given that respondents fill in one quarter of the surveys. Hence, within each of the 809 occupations, each skill measurement is based on 39 respondents on average. The published $\mathrm{O}^{*} \mathrm{NET}$ database contains occupation mean values and the original micro-data is not publicly available.

O*NET updates skill ratings of occupations on a continuous basis in a 5-year cycle. Every year, a new $\mathrm{O}^{*} \mathrm{NET}$ edition is being released which replaces the old skill ratings for a set of occupations with new ratings. 
Appendix 6.2: Results for workers in full-time jobs

Figure 6.5: The returns to analytical and interpersonal skills - Full-time workers

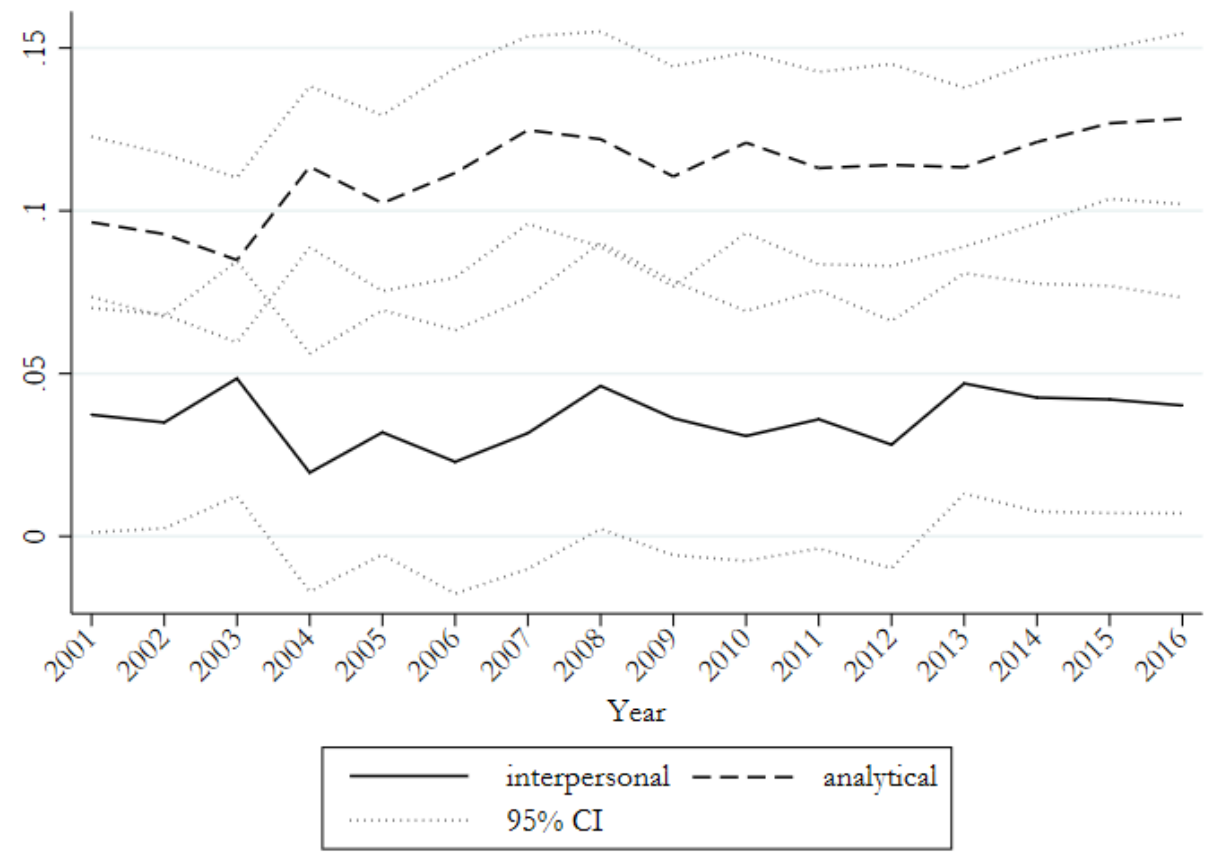

Notes: The lines represent the estimated regression coefficients for each year using specification (1).

Figure 6.6: The returns to analytical and interpersonal skills: Full-time private sector workers

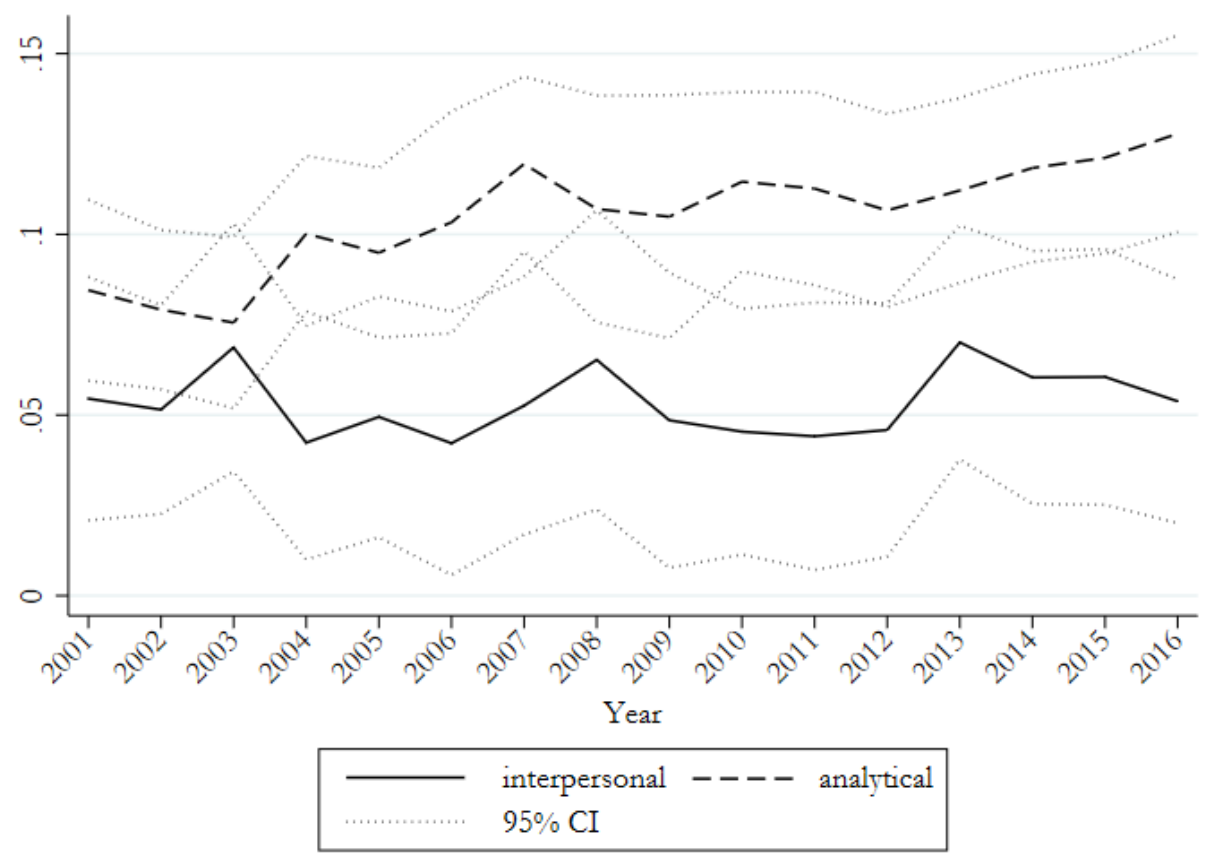

Notes: The lines represent the estimated regression coefficients for each year using specification (1). 
Chapter 6

Figure 6.7: The returns to analytical skills: quantile regression estimates - Fulltime workers

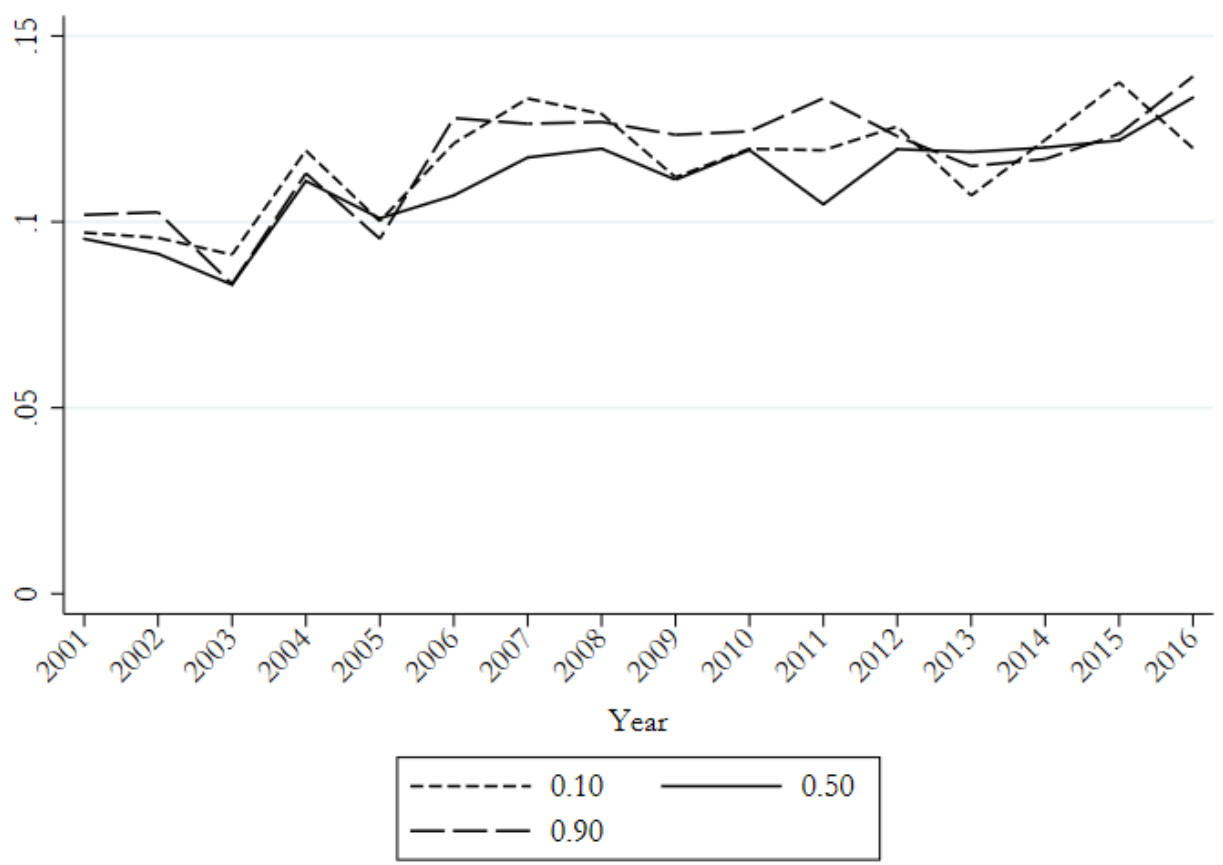

Notes: The lines represent the estimated regression coefficients for each year using specification (1).

Figure 6.8: The returns to interpersonal skills: quantile regression estimates Full-time workers

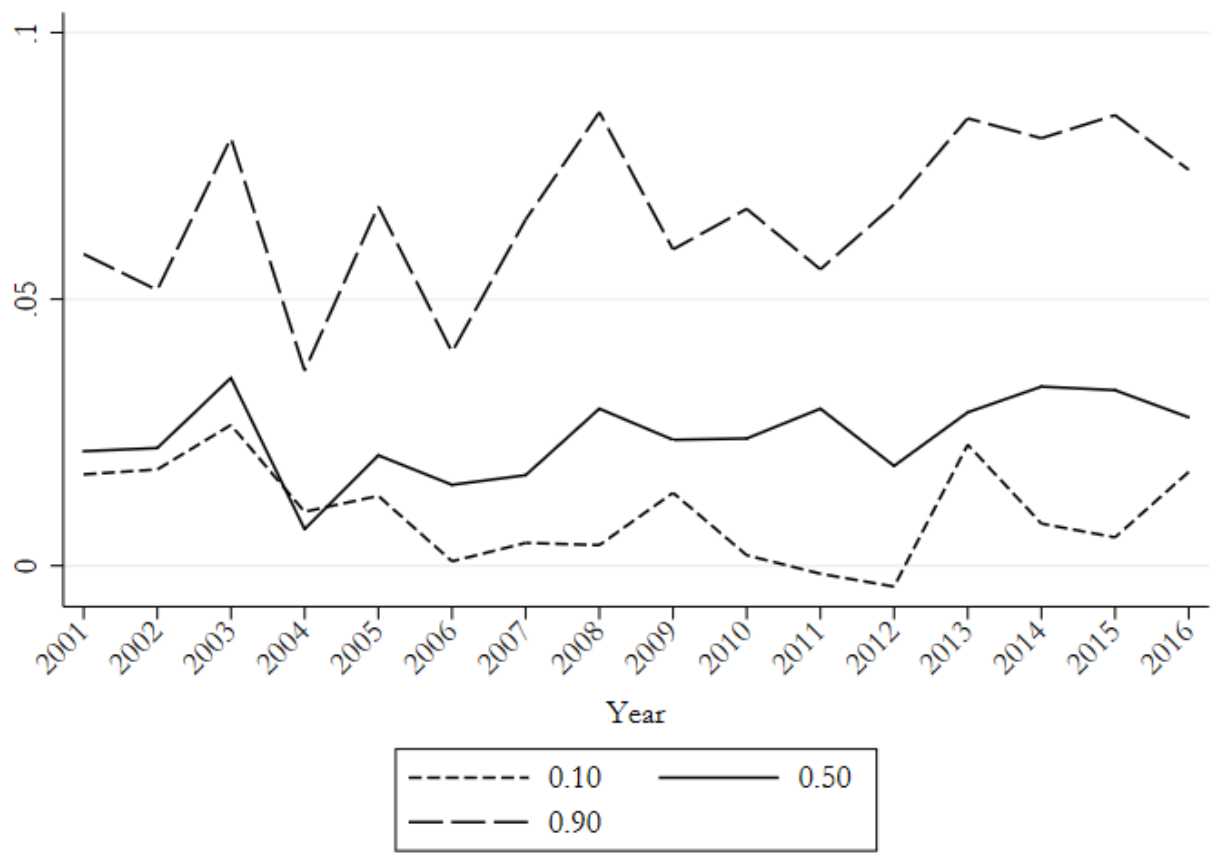

Notes: The lines represent the estimated regression coefficients for each year using specification (1). 




\section{Chapter 7}

Conclusion and Discussion 


\section{Conclusion and discussion}

An adequate match between the supply of human capital and the demand for labour is indispensable for a well-functioning labour market. A situation in which a proper match between the demand and supply of human capital is not realised is typically referred to as skill mismatch. For the individual, skill mismatch can lead to an increased risk in long unemployment spells, a wage loss, reduced job satisfaction as well as health-related issues. From a societal perspective, skill mismatch is an undesirable phenomenon as it can result into foregone tax revenues, but also into increased expenses on unemployment allowances. This thesis provides insight into the pervasiveness of skill mismatch on the (Dutch) labour market, investigates what measures can be taken to prevent it, and sheds light on the future demand for skills in the Netherlands. In this concluding chapter, I will first provide a brief summary of the results from the individual chapters. Next, I present the overall conclusions that can be drawn from this thesis and I will provide a more indepth discussion of the main findings.

Part I of this thesis sheds light on the pervasiveness of skill mismatch in the labour market. While a substantial amount of research and summaries are available on the causes, consequences, and incidence of vertical mismatch, an overview of the emerging literature on horizontal mismatch is lacking. Chapter 2 presents a systematic literature review on the determinants, consequences, and degree to which horizontal mismatch occurs on the international labour market. Across countries, between 21 and 46 percent of the graduates hold a job that is unrelated to their field-of-study. Compared to wellmatched workers, workers who experience horizontal mismatch generally incur a wage penalty, are less satisfied with their jobs, and are more likely to experience field-of-study choice regret. The degree to which horizontal mismatch is associated with adverse outcomes, is largely determined by the extent to which workers' skills are underutilized.

Chapter 3 explores how the incidence of skill gaps at the firm level has developed from a historical perspective in the Netherlands. For this purpose, I exploit a unique measure that captures whether companies' workforces possess the knowledge and skills that are required to adequately perform the job. This chapter illustrates that the match between workers' skills and job requirements has substantially improved between 1991-2011 from the perspective of employers. While in 1991 almost half of the Dutch employers reported that their workforce is not sufficiently equipped to meet the job requirements, in 2011 only a quarter of the employers reported mismatch. The findings indicate that the educational upgrading of the Dutch workforce has positively contributed to this trend.

Part II identifies measures that can prevent skill mismatch in the labour market. Chapter 4 explores whether offering a five-day intervention to students in pre-vocational education 
(pre-VET) can help to address the shortage of Science, Technology, Engineering and Mathematics (STEM) workers in the Netherlands. The evaluated intervention was launched in the schoolyear 2014-15 in the Amsterdam Metropolitan Area. The five-day programme introduced pre-VET students to a number of STEM occupations with favourable labour market perspectives (e.g. building \& construction and installation \& electrical engineering) through hands-on activities. Students were also assessed on their cognitive, vocational, and interpersonall skills. Based on these assessments, students received education advice. While the intervention did not increase the likelihood that native Dutch participants enrolled into STEM education in upper-secondary vocational education and training (VET), the intervention was effective in motivating students from an immigrant background to enrol into STEM.

Chapter 5 examines how unanticipated changes in the field-specific employment rate relate to the likelihood that graduates experience regret of the chosen field-of-study. In the Netherlands, more than one in four VET graduates experience study choice regret upon entry in the labour market. In this chapter, I demonstrate that the probability of experiencing regret is related to a discrepancy between the field-specific unemployment rate at the time the field-of-study is chosen and the unemployment rate upon labour market entry. This relationship is specifically pronounced when the labour market conditions at the time of entry into the labour market are less favourable than expected and only holds for male students. The findings suggest that increasing the availability of labour market forecasts could improve study choices and reduce study choice regret among VET graduates.

Finally, Part III sheds light on the changing skill requirements on the Dutch labour market. Chapter 6 specifically explores how the reward for non-routine skills has changed over the past two decades. The results indicate that analytical skills are increasingly rewarded on the Dutch labour market. The increasing reward for analytical skills is not only observed for workers in the upper-end of the wage distribution, but also for workers in the middle and lower-end of the wage distribution. In contrast, interpersonal skills are only increasingly valued in the upper-segment of the wage distribution.

The insights of this thesis has led to the formulation of five key conclusions which are printed in bold. Below, I provide a discussion of these conclusions along with the policy implications. In addition, I will discuss the limitations of the studies presented in this thesis and provide scope for future research.

1. Whether holding a job that is unrelated to the field-of-study reflects a suboptimal process of skill formation, strongly depends on the extent to which acquired skills are underutilised. 
Chapter 2 offers a systematic review of the literature and investigates the extent to which graduates hold jobs that do not match their field-of-study (i.e. horizontal mismatch). Moreover, this chapter investigates what the determinants and consequences are of horizontal mismatch. Several definitions of horizontal mismatch can be identified in the literature, each yielding different incidence rates varying from 21 to 46 percent.

Horizontal mismatch can result in a loss in earnings, a lower occupational status, reduced job satisfaction and an increased likelihood of experiencing regret in the chosen field-ofstudy. From this perspective, horizontal mismatch is likely to reflect a situation in which workers underutilize the skills they have acquired through their field-of-study. When horizontal mismatch is accompanied by unfavourable labour market outcomes, a mismatch between the job and the field-of-study indicates that the process of skill formation and the allocation of skills in the labour market are suboptimal. Horizontal mismatch is more likely to be associated with negative consequences when workers are not able to find a job that matches their field-of-study background and the reason is, therefore, demand related. In contrast, if the reason for horizontal mismatch is supply related, mismatched workers tend to incur a wage premium over their well-matched counterparts. Supply related reasons for horizontal mismatch include pay and promotion opportunities, or a change in career interests.

Horizontal mismatch is frequently measured by asking employees whether their field-ofstudy was a requirement for the job. According to this definition, workers who have mainly acquired general skills through their field-of-study are more likely to end up in jobs for which they have not been trained than workers who predominantly possess occupation-specific skills. However, being in a job for which the degree field was not a requirement does not necessarily reflect a situation of skill underutilization. Some employers might simply require more general skills that can be acquired through a variety of study programmes. Hence, the validity of horizontal mismatch measures can be called into question. The downside of this research is therefore that the reported incidence of horizontal mismatch does not perfectly reflect the pervasiveness of actual field-specific skill mismatch. Consequently, future research would benefit from a more uniform and unequivocal measure of horizontal mismatch that adequately captures whether graduates utilize the skills they have acquired through their field-of-study. Furthermore, the skills required in jobs only partially overlap with the skills acquired through formal education. Using education as a proxy for skills might ignore other important attributes of job requirements such as the human capital acquired through on the-job training and job experience. Hence, obtaining access to direct measures of the knowledge and skills that are required in jobs and possessed by workers is crucial for gaining a better insight in whether workers are horizontally matched. This especially holds true for workers in later 
stages of their career, who face changes in skill requirements as a result of technological progress. Future reviews of studies on horizontal mismatch should ideally include studies that directly compare the skills obtained in the field-of-study and those required in the labour market.

2. The educational upgrading of the Dutch labour force in the past two decades has contributed to a better equipped workforce from the perspective of employers. This trend has coincided with a growing demand for highly skilled workers, which explains the increasing returns to an additional year of schooling.

Chapter 3 examines to what degree Dutch employers face skill gaps by asking them whether their workforce is equipped to meet the job requirements of the coming years. This chapter subsequently studied how the incidence of skill mismatch has developed over the period 1991-2011 and whether the observed trend can be explained by the educational upgrading of the Dutch workforce. In 1991, almost half of the Dutch employers reported that their workforce is not sufficiently equipped to perform the job tasks, while in 2011, only a quarter of the employers reported skill mismatch. At the same time, the share of workers who graduated from higher education substantially increased between 1990 and 2010, while the number of individuals in the workforce with only a primary education diploma decreased over time. Chapter 3 shows that the educational upgrading of the Dutch labour force significantly contributed to this declining mismatch trend.

While this chapter shows that the increased educational attainment among the Dutch labour force has had positive implications for employers, these trends do not automatically imply that the match has also improved from the perspective of employees. Kampelmann and Rycx (2012) provide evidence that firm productivity can be enhanced as a result of the presence of over-educated workers. This suggests that mismatch from the employee's perspective can go hand in hand with an adequate worker-job match from the employer's perspective. Nonetheless, given that the rate of over-education remained stable over the past decade in the Netherlands (McGuinness, Bergin \& Whelan, 2018) ${ }^{72}$, it is unlikely that the declining mismatch trend was caused by an oversupply of skilled workers. Moreover, the earnings premium for highly educated workers continued to rise during the sample period (Van den Berge \& Ter Weel, 2015; Hartog \& Gerritsen, 2016). If the increased premium reflects a shortage of highly educated workers, an improved match between job requirements and workers' skills would suggest a gradual increase in the return on the investment in an additional year of schooling.

\footnotetext{
72 Between 2001 and 2011, the rate of over-educated graduates remained about 22 percent.
} 
While the findings reveal a causal relationship between the declining skill gap trend and increasing schooling attainment in the Netherlands, this study would benefit from a better understanding of the factors driving this relation. On the one hand, the findings might simply reflect that the educational upgrading of the Dutch labour force was a desirable response to the increased skill requirements in the labour market. However, the findings might also be the result of a number of policy efforts that aimed to improve the match between human capital formation and skill requirements in the labour market. ${ }^{73}$ Future research is encouraged to provide more insight into the underlying mechanisms between the outcome and explanatory variable of interest in this study.

\section{Students from an immigrant background can be motivated to enrol in STEM education through bands-on STEM engagement activities.}

Chapter 4 evaluates the effectiveness of a five-day intervention that was designed to motivate students from pre-VET to choose a STEM study programme in VET. The intervention was introduced in the schoolyear 2014-15 and aimed at addressing the shortage of qualified STEM workers in the Amsterdam Metropolitan Area. The intervention was offered to students in the final year of pre-VET (age 15-16).

The findings of this study indicate that the intervention had no significant effect on native Dutch male students. This could be explained by the fact that the intervention was targeted at pre-VET schools that attract students who already have a substantial interest in a STEM education. Hence, participants might also have enrolled into STEM education in absence of the intervention. In contrast, the intervention had a small but positive effect on the likelihood that male students with an immigrant background enrol into STEM education. A 1 percent increase of pre-VET students participating in the intervention enhanced the likelihood that they would enrol in STEM by 0.5 percent.

Although students with an immigrant background are likely to constitute a selective group of participants in this study, such students might nevertheless be more indecisive when it comes to enrolling into a STEM programme. Immigrant students tend to have negative associations with STEM occupations and less confidence in their ability to successfully complete a STEM programme (De Koning, 2008; De Koning et al., 2008;

\footnotetext{
${ }^{73}$ In the past decades, a variety of policy efforts were targeted at improving the match between the supply of educational programmes and the demand in the labour market (Onderwijsraad, 2012; Sociaal Economische Raad, 2002). In 2003, a policy law was introduced stating that government funds for higher education must be spent effectively and that higher education institutes can only offer new study programmes if they satisfy labour market demands. Consequently, several committees have been installed to evaluate the macro efficiency of study programmes in uppersecondary vocational education (Education and Vocational Education Act of 1995) as well as higher education (Higher Education and Research Act of 1992) since 2005.
} 
De Koning et al., 2010; Lent et al. 2005; Kuijpers \& Meijers, 2009; MacPhee et al., 2013; O’Brien, Martinez-Pons \& Kopala; 1999). Finally, immigrant students are on average less well-informed about the labour market perspectives of STEM programmes (De Koning et al., 2010). As such, uncertainty regarding students' preferences and ability, and the information deficiency regarding labour market perspectives, are likely to be greater for immigrant students. The intervention might have enhanced the confidence of immigrant students in their ability and preferences by allowing them to experience STEM occupations directly, through hands-on-activities. Moreover, the information provided to students about the labour market perspectives of STEM programmes might have reduced the information gap for students with an immigrant background. This would be consistent with earlier research demonstrating that students from lower socio-economic backgrounds, who experience on average more substantial information deficiencies, tend to be more sensitive to labour market information (Hoxby \& Turner, 2013; Wiswall \& Zafar, 2015b). Nevertheless, further research is required to point out through which channel migrant students were affected by the intervention.

A number of policy implications can be drawn from this study. First, the results suggest that offering future interventions to students who have not already shown a clear interest in STEM education might be more effective in triggering the students' interest in STEM. Consequently, it might be worthwhile to offer future interventions at an earlier stage in their educational career. Students enrol into sector-specific tracks after the second year of pre-VET and, therefore, shape their interests in a specific sector far earlier than in the final year of pre-VET. The findings indicate that hands-on STEM engagement activities can positively influence (immigrant) students' interest in pursuing a STEM career. STEM interventions ideally increase the likelihood that participants also end up in STEM jobs. Matching STEM jobs to STEM graduates remains a challenge in the Netherlands as an increasing share of STEM graduates end up in jobs that are unrelated to their field-ofstudy (ROA, 2017a). Future research is encouraged to explore whether the evaluated intervention is effective in terms of increasing the likelihood of completing a STEM study programme.

An important limitation of this study is that the students who actually participated in the intervention could not be directly identified. Instead, pre-VET schools were identified that were attended by the treated student subjects. Another drawback is the quasiexperimental nature of this study. Students were not randomly assigned to the treatment programme and control condition in order to ensure that both groups were equal in expectations. Schools situated outside the Amsterdam Metropolitan Area were used as a counterfactual. Because similar interventions might have taken place in other areas, this study provides a lower bound estimate of the causal effect of the intervention. 
4. Improving access to accurate labour market forecasts is a necessary, but not necessarily sufficient, precondition to improve the quality of students' field-of-study choice.

Chapter 5 sheds light on whether increasing the availability of labour market forecasts could improve the quality of educational choices of students who are about to enrol upper-secondary vocational education. Specifically, this chapter investigates how unanticipated changes in labour market conditions are related to the quality of educational choices as measured by whether graduates experience regret in their field-ofstudy choice upon labour market entry. While youngsters' expectations at the time they choose their course of study cannot be directly observed in the data, it is likely that students from a particular cohort gather relevant information by observing unemployment rates from earlier cohorts of graduates. The discrepancy between expectations and realisations is therefore measured by comparing the field-specific unemployment rate when the study choice is made with the unemployment rate at labour market entry.

The findings indicate that field-of-study choice regret is positively related to unfavourable changes in labour market conditions among male graduates: a 1 percentage point higher discrepancy between the field-specific unemployment rate when choosing a study programme and the unemployment rate at labour market entry is associated with a 14 percentage points greater likelihood of reporting regret. Such a relationship is not observed for female graduates. This gender difference could be driven by the fact that males and females make education and career choices on different grounds, males giving more attention to pecuniary aspects of their future job than do females (Zafar, 2013). Another potential reason for the male-female difference is that females sort into fields (e.g. healthcare) that are more stable across business cycles.

From a policy perspective, these findings suggest that students who are about to enrol in upper-secondary vocational education could benefit from improved availability of accurate labour market forecasts by field-of-study. Such forecasts entail particular relevance for vocational programmes due to the strong linkage between the skills acquired at school and the occupational demands for such skills. While improving the accessibility of labour market information is a necessary condition to improving the educational choices of youngsters, it remains unclear whether providing students with information alone is sufficient to affect the students' behaviour. Hence, policy makers should enable students to incorporate labour market information into the decisionmaking process.

A limitation of this study is that the data do not allow direct observation of students' expectations and whether they have been exposed to information about current and 
expected returns to education. Therefore, assumptions have been made concerning how and when students form their expectations about the future labour market. Ideally, future research on the topic addressed in this chapter would use direct measures of students' expectations regarding their labour market outcomes. Another important line for future research would be to evaluate what interventions can encourage students to incorporate available information into their decision-making process.

\section{Analytical skills are increasingly rewarded on the Dutch labour market in all segments of the wage distribution.}

Chapter 6 documents how different types of skills are rewarded on the Dutch labour market and shows how this has changed over the past two decades. Specifically, the study presented in this chapter examines how the labour market reward for non-routine analytical skills and non-routine interpersonal skills have changed between 2001 and 2016. The findings in this chapter point toward an increase in the premium for nonroutine analytical skills. The return to analytical skills increased from 9.4 percent in 2001 to 16.0 percent in 2016. The increasing reward for analytical skills is observed for workers in the upper-end of the wage distribution, but also in the middle- and lower-end of the distribution. A likely explanation for these findings is that the demand for non-routine tasks (i.e. interpreting and analysing information) has increased as computerization has improved the productivity of routine tasks (i.e. due to declining costs of retrieving and manipulating information). The rising premium suggests that the demand for analytical skills has outpaced the supply of such skills over the past two decades. Although certain tasks in many middle-skill jobs are susceptible to automation, the increasing return across all segments of the wage distribution indicates that many jobs will continue to require a changing set of skills. Hence, fostering the development of analytical skills will not only continue to be essential in higher education, but also in other segments of the education system.

Technological change not only boosted the productivity of workers performing nonroutine tasks, it has also reduced communication costs and induced greater organisational complexity (Caroli \& Van Reenen, 2001; Bresnahan et al., 2002). These changes have placed greater demands on workers with high levels of interpersonal communication and managerial skills. With respect to the reward for interpersonal skills, this chapter reports a decline from 3.3 percent in 2001 to 0.8 percent in 2016. Nonetheless, a considerable increase in the reward for interpersonal skills is found for full-time workers in the upperend of the wage distribution. For these workers, the premium for being employed in a job that requires a high level of interpersonal skills increased from 5.8 percent in 2001 to 7.4 percent in 2016. This finding is consistent with earlier studies documenting that 
Chapter 7

managerial interpersonal skills are increasingly demanded in the labour market (Autor et al., 2003; Borghans et al., 2007; Weinberger, 2014).

A limitation of this study is that the changing returns found in this study can solely be ascribed to changes in the occupational structure on the Dutch labour market. The O*NET skill measures are assigned at the occupational level and we therefore ignore potential heterogeneity in job tasks across individuals holding similar occupations. Prior research emphasized the importance of within-occupation variation in tasks in explaining wage differentials (Arntz et al., 2017; Autor \& Handel, 2013; Cassidy, 2017). Thus, future research will benefit from new skill indicators that are measured at the level of workers. 



\section{References}

Acemoglu, D., \& Autor, D. H. (2011). Skills, tasks and technologies: Implications for employmentand earnings. In O. C. Ashenfelter \& D. Card (Eds.), Handbook of Labor Economics (Vol. 4, pp. 1043-1171). Amsterdam, The Netherlands: Elsevier.

Allen, J., \& Van der Velden, R. (2001). Educational mismatches versus skill mismatches: Effects on wages, job satisfaction, and on-the-job search. Oxford Economic Papers, 53(3), 434-452.

Altonji, J. G., Arcidiacono, P., \& Maurel, A. (2016). The analysis of field choice in college and graduate school: Determinants and wage effects. In E. A. Hanushek, S. J. Machin \& L. Woessmann (Eds.), Handbook of the Economics of Education (Vol. 5, pp. 305-396). Amsterdam, The Netherlands: Elsevier.

Altonji, J. G., \& Blank, R. M. (1999). Race and gender in the labor market. In O. C. Ashenfelter \& D. Card (Eds.), Handbook of Labor Economics (pp. 3143-3259). Amsterdam, The Netherlands: Elsevier.

Altonji, J. G., Blom, E., \& Meghir, C. (2012). Heterogeneity in human capital investments: High school curriculum, college major, and careers. Annual Review of Economics, 4(1), 185-223.

Andersen, R. T., \& Van de Werfhorst, H. G. (2010). Education and occupational status in 14 countries: The role of educational institutions and labour market coordination. The British Journal of Sociology, 61(2), 336-355.

Angrist, J. D., Imbens, G. W., \& Rubin, D. B. (1996). Identification of causal effects using instrumental variables. Journal of the American Statistical Association, 91(434), 444-55.

Angrist, J. D., \& Pischke, J. S. (2008). Mostly harmless econometrics: An empiricist's reencompanion. Princeton, NJ: Princeton University Press.

Arcidiacono, P., Hotz, V. J., \& Kang, S. (2012). Modeling college major choices using elicited measures of expectations and counterfactuals. Journal of Econometrics, 166(1), 3-16.

Arntz, M., Gregory, T., \& Zierahn, U. (2017). Revisiting the risk of automation. Economic Letters, 159, 157-160. 
Autor, D. H. (2003). Outsourcing at will: The contribution of unjust dismissal doctrine to the growth of employment outsourcing. Journal of Labor Economics, 21(1), 1-42.

Autor, D. H., \& Dorn, D. (2013). The growth of low-skill service jobs and the polarization of the US labor market. American Economic Review, 103(5), 1553-1597.

Autor, D. H., \& Handel, M. J. (2013). Putting tasks to the test: Human capital, job tasks, and wages. Journal of Labor Economics, 31(S1), S59-S96.

Autor, D. H., Katz, L. F., \& Kearney, M. S. (2006). Measuring and interpreting trends in economic inequality. American Economic Review, 96(2), 189-194.

Autor, D. H., Katz, L. F., \& Krueger, A. B. (1998). Computing inequality: Have computers changed the labor market? The Quarterly Journal of Economics, 113(4), 1169-1213.

Autor, D. H., Levy, F., \& Murnane, R. J. (2003). The skill content of recent technological change: An empirical exploration. The Quarterly Journal of Economics, 118(4), 12791333.

Ball, L. M. (2009). Hysteresis in unemployment: Old and new evidence (NBER Working Paper No. 14818).

Bamberger, Y. M. (2014). Encouraging girls into science and technology with feminine role model: Does this work? Journal of Science Education and Technology, 23(4), 549561.

Bardhan, A., Hicks, D., \& Jaffee, D. (2013). How responsive is higher education? The linkages between higher education and the labour market. Applied Economics, 45(10), 1239-1256.

Bartel, A. P. (1994). Workplace training in the United States. In S. Aseta \& W. C. Huang (Eds.), Human Capital and Economic Development (pp. 109-28). Kalamazoo, MI: W.E. Upjohn Institute for Employment Research.

Bartel, A. P., \& Lichtenberg, F. R. (1987). The skill distribution and competitive trade advantage of high-technology industries. Advances in Industrial and Labor Relations, 4, $161-76$.

Beaudry, P., Green, D. A., \& Sand, B. M. (2016). The great reversal in the demand for skill and cognitive tasks. Journal of Labor Economics, 34(S1), S199-S247. 
Becker, G. S. (1994). Human capital: A theoretical and empirical analysis, with special reference to education (3 $3^{\text {rd }}$ ed.). Chicago, IL: University of Chicago Press.

Bedard, K. (2001). Human capital versus signaling models: University access and high school dropouts. Journal of Political Economy, 109(4), 749-775.

Béduwé, C., \& Giret, J. (2011). Mismatch of vocational graduates: What penalty on French labour market? Journal of Vocational Behavior, 78(1), 68-79.

Beffy, M., Fougère, D., \& Maurel, A. (2012). Choosing the field-of-study in postsecondary education: Do expected earnings matter? Review of Economics and Statistics, 94(1), 334-347.

Belfield, C. (2010). Over-education: What influence does the workplace have? Economics of Education Review, 29(2), 236-45.

Bell, D. E. (1982). Regret in decision making under uncertainty. Operations Research, 30, 961-981.

Bender, K. A., \& Heywood, J. S. (2011). Educational mismatch and the careers of scientists. Education Economics, 19(3), 253-274.

Bender, K. A., \& Roche, K. (2013). Educational mismatch and self-employment. Economics of Education Review, 34, 85-95.

Bennett, J., \& McGuinness, S. (2009). Assessing the impact of skill shortages on the productivity performance of high-tech firms in Northern Ireland. Applied Economics, 41(6), 727-737.

Benz, M., \& Frey, B. S. (2008). Being independent is a great thing: Subjective evaluations of self-employment and hierarchy. Economica, 75(298), 362-383.

Berge, van den W., \& Ter Weel, B. (2015). Baanpolarisatie in Nederland (CPB Policy Brief No. 13). The Hague, The Netherlands: Centraal Planbureau.

Bertrand, M., Duflo, E., \& Mullainathan, S. (2004). How much should we trust differences-indifferences estimates? The Quarterly Journal of Economics, 119(1), 249275.

Bettinger, E. P., \& Long, B. T. (2009). Addressing the needs of underprepared students in higher education does college remediation work? Journal of Human Resources, 44(3), 736-771. 
Betts, J. R. (1996). What do students know about wages? Evidence from a survey of undergraduates. Journal of Human Resources, 31(1), 27-56.

Blinder, A. S. (2009). How many US jobs might be offshorable? World Economics, 10(2), 41-78.

Böhlmark, A., \& Lindquist, M. J. (2006). Life-cycle variations in the association between current and lifetime income: Replication and extension for Sweden. Journal of Labor Economics, 24(4), 879-896.

Bol, T., \& Van de Werfhorst, H. G. (2016). Measuring educational institutional diversity: External differentiation, vocational orientation and standardization. In: A. Hadjar \& C. Gross (Eds.), Education Systems and Inequalities (pp. 73-94). Bristol, England: Policy Press.

Booth, A. L., Francesconi, M., \& Frank, J. (2002). Temporary jobs: Stepping stones or dead ends? The Economic Journal, 112(480), F189-F213.

Borghans, L., \& Golsteyn, B. (2005). De kwaliteit van de studiekeuze. In: De arbeidsmarkt naar opleiding en beroep tot 2010 (pp. 93-119). Maastricht, The Netherlands: Research Centre for Education and the Labour Market.

Borghans, L., \& Golsteyn, B. (2006). De kosten van uitgesteld leren. Maandschrift Economie, 3, 291-300.

Borghans, L., \& Golsteyn, B. (2007). Skills transferability, regret and mobility. Applied Economics, 39(13), 1663-1677.

Borghans, L., \& De Grip, A. (2000). The overeducated worker? The economics of skill utilization. Cheltenham, UK: Edward Elgar Publishing.

Borghans, L., De Grip, A., \& Heijke, H. (1996). Labor market information and the choice of vocational specialization. Economics of Education Review, 15(1), 59-74.

Borghans, L., Golsteyn, B., \& Stenberg, A. (2015). Does expert advice improve educational choice? PloS ONE, 10(12), e0145378.

Borghans, L., Ter Weel, B., \& Weinberg, B. A. (2008). Interpersonal styles and labor market outcomes. Journal of Human Resources, 43(4), 815-858.

Boswell, W. R., Roehling, M. V., LePine, M. A., \& Moynihan, L. M. (2003). Individual job-choice decisions and the impact of job attributes and recruitment practices: A longitudinal field study. Human Resource Management 42(1), 23-37. 
Botelho, A., \& Costa Pinto, L. (2004). Students' expectations of the economic returns to college education: Results of a controlled experiment. Economics of Education Review 23(6), 645-653.

Boudarbat, B., \& Chernoff, V. (2012). Education-job match among recent Canadian university graduates. Applied Economics Letters, 19(18), 1923-1926.

Bound, J., Jaeger, D. A., \& Baker, R. M. (1995). Problems with instrumental variables estimation when the correlation between the instruments and the endogenous explanatory variable is weak. Journal of the American Statistical Association, 90(430), 443-450.

Bound, J., \& Johnson, G. (1992). Changes in the structure of wages in the 1980s: An evaluation of alternative perspectives. American Economic Review, 82(3), 371-92.

Breen, R. (2005). Explaining cross-national variation in youth unemployment market and institutional factors. European Sociological Review, 21(2), 125-134.

Bresnahan, T. F., Brynjolfsson, E., \& Hitt, L. M. (2002). Information technology, workplace organization, and the demand for skilled labor: Firm-level evidence. The Quarterly Journal of Economics, 117(1), 339-376.

Brunello, G., Lucifora, C., \& Winter-Ebmer, R. (2001). The wage expectations of European college students (IZA Discussion Paper No. 229).

Brynjolfsson, E., \& McAfee, A. (2014). The second machine age: Work, progress, and prosperity in a time of brilliant technologies. New York City, NY: WW Norton \& Company.

Büchel, F. (2002). The effects of overeducation on productivity in Germany - The firms' viewpoint. Economics of Education Review, 21(3), 263-75.

Büchel, F., \& Van Ham, M. (2003). Overeducation, regional labor markets, and spatial flexibility. Journal of Urban Economics, 53(3), 482-493.

Budría, S., \& Moro-Egido, A. I. (2008). Education, educational mismatch, and wage inequality: Evidence for Spain. Economics of Education Review, 27(3), 332-341.

BusinessEurope (2011). Plugging the skills gap - The clock is ticking. Retrieved from https://www.businesseurope.eu/sites/buseur/files/media/imported/201100855-E.pdf

Caldwell, D. F., \& O’Reilly, C. A. (1990). Measuring person-job fit with a profilecomparison process. Journal of Applied Psychology, 75(6), 648-57. 
Cappelli, P. (2008). Talent management for the twenty-first Century. Harvard Business Review, 86(3), 74-81.

Card, D. (1999). The causal effect of education on earnings. In O. C. Ashenfelter \& D. Card (Eds.), Handbook of Labor Economics (Vol. 3, pp. 1801-1863). Amsterdam, The Netherlands: Elsevier.

Caroli, E., \& Van Reenen, J. (2001). Skill-biased organizational change? Evidence from a panel of British and French establishments. The Quarterly Journal of Economics, 116(4), 1449-1492.

Carstensen, L. L., Pasupathi, M., Mayr, U., \& Nesselroade, J. R. (2000). Emotional experience in everyday life across the adult life span. Journal of Personality and Social Psychology, 79, 644-655.

Carvajal, M. J., Bendana, D., Bozorgmanesh, A., Castille, M. A., Pourmasiha, K., Rao, P., \& Torres, J. A. (2000). Inter-gender differentials between college students' earnings expectations and the experience of recent graduates. Economics of Education Review, 19(3), 229-243.

Cassidy, H. (2017). Task variation within occupations. Industrial Relations: A Journal of Economy and Society, 56(3) 393-410.

Castex, G., \& Kogan Dechter, E. (2014). The changing roles of education and ability in wage determination. Journal of Labor Economics, 32(4), 685-710.

Cedefop (2014a). EU skills panorama: Analytical highlights-focus on science, technology, engineering and mathematcs (STEM) skills. Retrieved from http://skillspanorama.cedefop.europa.eu/sites/default/files/EUSP_AH_STEM_ $0 . p d f$

Cedefop (2014b). Rising STEMs. Retrieved from http://www.cedefop.europa.eu/en/publications-and-resources/statistics-andindicators/statistics-and-graphs/rising-stems

Cedefop. (2016, April 1). Cedefop's latest skill supply and demand forecasts highlight Europe's employment challenge. Retrieved from http://www.cedefop.europa.eu/nl/news-and-press/news/cedefops-latest-skillsupply-and-demand-forecasts-highlight-europes-employment

Chatman, J. A. (1991). Matching people and organizations: Selection and socialization in public accounting firms. Administrative Science Quarterly, 36(3), 459-84. 
Chevalier, A. (2002). Education, motivation and pay of UK Graduates: are they different for women? European Journal of Education, 37(4), 347-369.

Chevalier, A. (2003). Measuring over-education. Economica, 70(279), 509-531.

Clark, T. S., \& Linzer., D. A. (2015). Should I use fixed or random effects? Political Science Research and Methods, 3(2), 399-408.

Conlon, J. (2017). Major malfunction: A field experiment correcting undergraduates' beliefs about salaries. Federal Reserve Bank of New York, mimeo.

Connelly, R. (1992). Self-employment and providing child care. Demography, 29(1), 17-29.

Constan, Z., \& Spicer, J. J. (2015). Maximizing future potential in physics and STEM: Evaluating a summer program through a partnership between science outreach and education research. Journal of Higher Education Outreach and Engagement, 19(2), 117-136.

Cosser, M. (2010). The skills cline: Higher education and the supply-demand complex in South Africa. Higher Education, 59(1), 43-53.

Dawes, M. E., Horan, J. J., \& Hackett, G. (2000). Experimental evaluation of self-efficacy treatment on technical/scientific career outcomes. British Journal of Guidance and Counselling, 28(1), 87-99.

De Philippis, M. (2017). STEM graduates and secondary school curriculum: Does early exposure to science matter? (Bank of Italy Working Paper No. 1107).

Deming, D. J. (2017). The growing importance of social skills in the labor market. The Quarterly Journal of Economics, 132(4), 1593-1640.

Di Pietro, G., \& Urwin, P. (2006). Education and skills mismatch in the Italian graduate labour market. Applied Economics, 38(1), 79-93.

Diaz-Serrano, L., \& Nilsson, W. (2017). The reliability of students' earnings expectations (IZA Discussion Paper No. 10700).

Dolton, P. J., \& Silles, M. A. (2008). The effects of over-education on earnings in the graduate labour market. Economics of Education Review, 27(2), 125-139.

Dolton, P., \& Vignoles, A. (2000). The incidence and effects of overeducation in the UK graduate labour market. Economics of Education Review, 19(2), 179-198. 
Dow, J. C. R., \& Dicks-Mireaux, L. A. (1958). The excess demand for labour: A study of conditions in Great Britain, 1946-56. Oxford Economic Papers, 10(1), 1-33.

Duncan, G. J., \& Hoffman, S. D. (1981). The economic value of surplus education. Economics of Education Review, 1(1), 75-86.

Edin, P. A., Fredriksson, P., Nybom, M., \& Ockert, B. (2017). The rising return to noncognitive skill (IZA Discussion Paper No. 10914).

Egger, M., Zellweger-Zähner, T., Schneider, M., Junker, C., Lengeler, C., \& Antes, G. (1997). Language bias in randomised controlled trials published in English and German. The Lancet, 350(9074), 326-329.

European Commission (2014). Innovation Union Competitiveness Report 2013. Retrieved from https://ec.europa.eu/research/innovationunion/pdf/competitiveness_report_2013.pdf

European Commission (2008). New skills for new jobs. Anticipating and matching labour market and skill needs (COM(2008) 868 final). Retrieved from: https://eurlex.europa.eu/legalcontent/EN/TXT/?qid=1561894143376\&uri=CELEX:52008SC3058

European Commission (2016). A new skills agenda for Europe. Working together to strengthen buman capital, employability and competitiveness (COM(2016) 381 final). Retrieved from: https:// eur-lex.europa.eu/legal-content/EN/TXT/?uri=CELEX:52016DC0381

European Economic and Social Committee ( 2018). Skills mismatches. An impediment to the competitiveness of EU businesses. Retrieved from: https://www.eesc.europa.eu/en/our-work/publications-otherwork/publications/skills-mismatches-impediment-competitiveness-eubusinesses\#downloads

Farooq, S. (2011). The utilisation of education and skills: Incidence and determinants among Pakistani graduates. The Pakistan Development Review, 50(3), 219-244.

Fischer, A. H. (2000). Gender and emotion: Social psychological perspectives. Cambridge, UK: Cambridge University Press.

Fouarge, D., De Koning, B., \& Künn-Nelen, A. (2018). The determinants of education advise. Maastricht University, mimeo. 
Fouarge, D., Kriechel, B., \& Dohmen, T. (2014). Occupational sorting of school graduates: The role of economic preferences. Journal of Economic Behavior \& Organization, 106, 335-351.

Freeman, R. B. (1971). The market for college-trained manpower: A study in the economics of career choice. Cambridge, MA: Harvard University Press.

Galandi, D., Schwarzer, G., \& Antes, G. (2006). The demise of the randomised controlled trial: Bibliometric study of the German-language health care literature, 1948 to 2004. BMC Medical Research Methodology, 6(1), 30.

Gautier, P., Van den Berg, G., Van Ours, J., \& Ridder, G. (2002). Worker turnover at the firm level and crowding out of lower educated workers. European Economic Review, 46(3), 523-538.

Gemici, A., \& Wiswall, M. (2014). Evolution of gender differences in post-secondary human capital investments: College Majors. International Economic Review, 55(1), 2356.

Gibson, H. L., \& Chase, C. (2002). Longitudinal impact of an inquiry-based science program on middle school students' attitudes toward science. Science Education, 86(5), 693-705.

Goldin, C., \& Katz, L. (2008). The race between technology and education. Cambridge, MA: Harvard University Press.

Goldin, C., \& Katz, L. F. (1996). The origins of technology-skill complementarity. The Quarterly Journal of Economics, 113(3), 693-732.

Goos, M., \& Manning, A. (2007). Lousy and lovely jobs: The rising polarization of work in Britain. The Review of Economics and Statistics, 89(1), 118-133.

Goos, M., Manning, A., \& Salomons, A. (2009). Job polarization in Europe. The American Economic Review, 99(2), 58-63.

Goos, M., Manning, A., \& Salomons, A. (2014). Explaining job polarization: Routinebiased technological change and offshoring. American Economic Review, 104(8), 2509-26.

Gosling, A., Machin, S. J., \& Meghir, C. (2000). The changing distribution of male wages in the UK. The Review of Economic Studies, 67(4), 635-666. 
Green, F. (2006). Demanding work: The paradox of job quality in the affluent economy. Princeton, NJ: Princeton University Press.

Green, F., \& Zhu, Y. (2010). Overqualification, job dissatisfaction, and increasing dispersion in the returns to graduate education. Oxford Economic Papers, 62(4), 740763.

Greenes, C., Wolfe, S., Weight, S., Cavanagh, M., \& Zehring, J. (2011). Prime the pipeline project (P3): Putting knowledge to work. Contemporary Issues in Technology and Teacher Education, 11(1), 21-46.

Grip, de A., \& Van Loo, J. (2002). The economics of skills obsolescence: A review. In A. de Grip, J. van Loo \& K. Mayhew (Eds.), The economics of skills obsolescence (Vol 21. pp. 1-26). Bingley, England: Emerald Group Publishing Limited.

Groeneveld, S., \& Hartog, J. (2004). Overeducation, wages and promotions within the firm. Labour Economics, 11(6), 701-714.

Groot, W., \& Maassen van den Brink, H. M. (1996). Overscholing en verdringing op de arbeidsmarkt. Economisch-Statistische Berichten, 81(4042), 74-77.

Groot, W., \& Maassen van den Brink, H. M. (2000). Overeducation in the labor market: A meta-analysis. Economics of Education Review, 19(2), 149-158.

Groshen, E. L., \& Potter, S. (2009). Has structural change contributed to a jobless recovery? Current Issues in Economics and Finance, 9(8), 1-7.

Haider, S., \& Solon, G. (2006). Life-cycle variation in the association between current and lifetime earnings. American Economic Review, 96(4), 1308-1320.

Ham, van M., Hooimeijer, P., \& Mulder, C. H. (2001). Urban form and job access: Disparate realities in the randstad. Tijdschrift voor Economische en Sociale Geografie, 92(2), 231-46.

Hamilton, S. F. (1987). Apprenticeship as a transition to adulthood in West Germany. American Journal of Education, 95, 314-345.

Handel, M. (2012). Trends in job skill demands in OECD countries (OECD Social, Employment and Migration Working Papers No. 143). Paris, France: OECD Publishing. 
Hanushek, E. A. (2009). The economic value of education and cognitive skills. In G. Sykes, B. Schneider, \& D. N. Plank (Eds.), Handbook of education policy research (pp. 39-56). New York, NY: Routledge.

Hanushek, E. A., \& Woessmann, L. (2008). The role of cognitive skills in economic development. Journal of Economic Literature, 46(3), 607-68.

Hanushek, E. A., \& Woessmann, L. (2012). Do better schools lead to more growth? Cognitive skills, economic outcomes, and causation. Journal of Economic Growth, 17(4), 267-321.

Harmon, C., Oosterbeek, H., \& Walker, I. (2003). The returns to education: Microeconomics. Journal of Economic Surveys, 17(2), 115-156.

Hartog, J. (2000). Over-education and earnings: Where are we, where should we go? Economics of Education Review, 19(2), 131-147.

Haskel, J., \& Martin, C. (2001). Technology, wages, and skill shortages: Evidence from UK micro data. Oxford Economic Papers, 53(4), 642-658.

Hastings, J., Neilson, C. A., \& Zimmerman, S. D. (2015). The effects of earnings disclosure on college enrollment decisions (NBER Working Paper No. w21300).

Hayashi, F. (2000). Econometrics. Princeton, NJ: Princeton University Press.

Haveman, R., \& Wolfe, B. (1995). The determinants of children's attainments: A review of methods and findings. Journal of Economic Literature, 33(4), 1829-1878.

Heap, S. H., Hollis, M., Lyons, B., Sugden, R., \& Weale, A. (1992). The theory of choice: A critical guide. Hoboken, NJ: Wiley-Blackwell.

Heckman, J. J., Lochner, L. J., \& Todd, P. E. (2006). Earnings functions, rates of return and treatment effects: The Mincer equation and beyond. In E. A. Hanushek, S. J. Machin \& L. Woessmann (Eds.), Handbook of the Economics of Education (Vol 1. pp. 307-458). Amsterdam, The Netherlands: Elsevier.

Heijke, H., Meng, C., \& Ris, C. (2003). Fitting to the job: The role of generic and vocational competencies in adjustment and performance. Labour Economics, 10(2), 215-229.

Hensen, M. M., De Vries, M. R., \& Cörvers, F. (2009). The role of geographic mobility in reducing education-job mismatches in the Netherlands. Papers in Regional Science, 88(3), 667-682. 
Hersch, J. (1991). Education match and job match. Review of Economics and Statistics, 73(1), 140-44.

Hiller, S. E., \& Kitsantas, A. (2014). The effect of a horseshoe crab citizen science program on middle school student science performance and STEM career motivation. School Science and Mathematics, 114(6), 302-311.

Holland, J. J. (1985). Vocational Preference Inventory: Professional Manual. Odessa, FL: Psychological Assessment Resources.

Holland, J. J., Gottfredson, D. C., \& Power, P. G. (1980). Some diagnostic scales for research in decision making and personality: Identity, information, and barriers. Journal of Personality and Social Psychology, 39, 1191-1200.

ILO (2014). Skills mismatch in Europe. Geneva, Switzerland: ILO Publications.

Ingram, B. F., \& Neumann, G. R. (2006). The returns to skill. Labour Economics, 13(1), 3559.

Jackson, G. A. (1982). Public efficiency and private choice in higher education. Educational Evaluation and Policy Analysis, 4(2), 237-247.

Jacobs, B., \& Webbink H. D. (2006). Het rendement op onderwijs blijft stijgen. Economisch Statistische Berichten, 91(4492), 405-407.

Jayaratne, T. E., Thomas, N. G., \& Trautmann, M. (2003). Intervention program to keep girls in the science pipeline: Outcome differences by ethnic status. Journal of Research in Science Teaching, 40(4), 393-414.

Jensen, R. (2010). The (perceived) returns to education and the demand for schooling, The Quarterly Journal of Economics, 125(2), 515-548.

Jovanovic, B. (1979). Job matching and the theory of turnover. The Journal of Political Economy, 87(5, Part 1), 972-990.

Kahneman, D., \& Miller, D. T. (1986). Norm theory: Comparing reality to its alternatives. Psychological Review, 93(2), 136-153.

Kalleberg, A. L., \& Van Buren, M. E. (1992). Organizations and economic stratification: A cross-national analysis of the size-earnings relation. Research in Social Stratification and Mobility, 11, 61-93. 
Kampelmann, S., \& Rycx, F. (2012). The impact of educational mismatch on firm productivity: Evidence from linked panel data. Economics of Education Review, 31(6), 918-931.

Katz, L. F., \& Murphy, K. M. (1992). Changes in relative wages, 1963-1987: Supply and demand factors. The Quarterly Journal of Economics, 107(1), 35-78.

Hartog, J., \& Gerritsen, S. (2016). Mincer earnings functions for the Netherlands 19622012. De Economist, 164(3), 235-253.

Kaufmann, K. (2014). Understanding the income gradient in college attendance in Mexico: The role of heterogeneity in expected returns. Quantitative Economics, 5(3), 583-630.

Kiker, B. F., Santos, M. C., \& De Oliveira, M. M. (1997). Overeducation and undereducation: Evidence for Portugal. Economics of Education Review, 16(2), 111125.

Kim, H., \& Chae, D. (2016). The development and application of a STEAM program based on traditional Korean culture. Eurasia Journal of Mathematics, Science \& Technology, 12(7), 1925-1936.

Kirkebøen, L. J., Leuven, E., \& Mogstad, M. (2016). Field of study, earnings, and self selection. The Quarterly Journal of Economics, 131(3), 1057-1111.

Klein, M. (2011). Higher education and non-pecuniary returns in Germany: tracing the mechanisms behind field of study effects at the start of the career. Irish Educational Studies, 30(2), 253-270.

Koning, de J., Gelderblom, A., \& Gravesteijn, J. (2010). Techniek: Exact goed? Het keuzeproces van allochtone en autochtone leerlingen in het (v)mbo verklaard. Rotterdam, The Netherlands: SEOR, Erasmus Universiteit Rotterdam.

Koning, de J., Gelderblom, A., Den Hartog, L., \& Berretty, T. (2008). Vermindering arbeidsmarktknelpunten: de rol van onderwijs en scholing. Rotterdam, The Netherlands: SEOR, Erasmus Universiteit Rotterdam.

Koning, de J. (2008). Techniek in het umbo en bet mbo: naar een betere afstemming van onderwijskeuzes van allochtone leerlingen op aanleg en arbeidsmarktbehoefte. Rotterdam, The Netherlands: SEOR, Erasmus Universiteit Rotterdam.

Krueger, A. B., \& Lindahl, M. (2001). Education for growth: Why and for whom?. Journal of Economic Literature, 39(4), 1101-1136. 
Kucel, A., \& Vilalta-Bufí, M. (2012). Graduate labor mismatch in Poland. Polish Sociological Review, 3(179), 413-429.

Kucel, A., \& Vilalta-Bufí, M. (2013). Why do tertiary education graduates regret their study program? A comparison between Spain and the Netherlands. Higher Education, 65(5), 565-579.

Kuijpers, M., \& Meijers, F. (2009). Beroepsbeelden, -wensen en -voorkeuren van allochtone ouders. Utrecht, The Netherlands: FORUM, Instituut voor Multiculturele Ontwikkeling.

Lamo, A., \& Messina, J. (2010). Formal education, mismatch and wages after transition: Assessing the impact of unobserved heterogeneity using matching estimators. Economics of Education Review, 29(6), 1086-1099.

Landman, J. (1987). Regret and elation following action and inaction: Affective responses to positive versus negative outcomes. Personality and Social Psychology Bulletin, 13, 524-536.

Lazaer, E. P., \& Spletzer, J. R. (2012). The United States labor markt: Status quo or a new normal? (NBER Working Paper No. 18386).

Leuven, E., \& Oosterbeek, H. (2000). Rendement van onderwijs stijgt. Economisch Statistische Berichten, 85(4262), 523-24.

Levels, M., Van der Velden, R., \& Di Stasio, V. (2014). From school to fitting work: How education-to-job matching of European school leavers is related to educational system characteristics. Acta Sociologica, 57(4), 341-361.

Levin, H. M., \& Rouse, C. E. (2012, January 25). The New York Times: The true cost of high school dropouts. Retrieved from https://www.nytimes.com/2012/01/26/opinion/the-true-cost-of-highschool-dropouts.html?mtrref=www.google.com\&gwh=6BE17578FDB665DE59 E5B0BDD3B73245\&gwt=pay\&asset'Type=REGIWALL

Levin, H. M., Belfield, C., Muennig, P. A., \& Rouse, C. (2007). The costs and benefits of an excellent education for all America's children. New York, NY: Teachers College Press.

Liu, K., Salvanes, K. G., \& Sørensen, E. Ø. (2016). Good skills in bad times: Cyclical skill mismatch and the long-term effects of graduating in a recession. European Economic Review, 84, 3-17. 
Loomes, G., \& Sugden, R. (1987). Testing for regret and disappointment in choice under uncertainty. The Economic Journal, 97, 118-129.

Machin, S. J., \& McNally, S. (2007). Tertiary education systems and labour markets. Paris, France: OECD Publishing.

Machin, S. J., \& Van Reenen, J. (1998). Technology and changes in skill structure: Evidence from seven OECD countries. The Quarterly Journal of Economics, 113(4), 1215-44.

MacPhee, D., Farro, S., \& Canetto, S. S. (2013). Academic self-efficacy and performance of underrepresented STEM majors: Gender, ethnic, and social class patterns. Analyses of Social Issues and Public Policy, 13(1), 347-369.

Malamud, O. (2010). Breadth versus depth: The timing of specialization in higher education. Labour, 24(4), 359-390.

Malamud, O. (2011). Discovering one's talent: Learning from academic specialization. Industrial and Labor Relations Review, 64(2), 375-405.

Marzo-Navarro, M., Pedraja-Iglesias, M., \& Rivera-Torres, P. (2009). Curricular profile of university graduates versus business demands: Is there a fit or mismatch in Spain? Education + Training, 51(1), 56-69.

Mason, G. (1996). Graduate utilisation in British industry: The initial impact of mass higher education. National Institute Economic Review, 156(1), 93-103.

McGoldrick, K., \& Robst, J. (1996). Gender differences in overeducation: A test of the theory of differential overqualification. The American Economic Review, 86(2), 280284.

McGuigan, M., McNally, S., \& Wyness, G. (2016). Student awareness of costs and benefits of educational decisions: Effects of an information campaign. Journal of Human Capital, 10(4), 482-519.

McGuinness, S. (2006). Overeducation in the labour market. Journal of Economic Surveys, 20(3), 387-418.

McGuinness, S., \& Bennett, J. (2007). Overeducation in the graduate labour market: A quantile regression approach. Economics of Education Review, 26(5), 521-531.

McGuinness, S., \& Ortiz, L. (2016). Skill gaps in the workplace: Mmeasurement, determinants and impacts. Industrial Relations Journal, 47(3), 253-278. 
McGuinness, S., \& Sloane, P. J. (2011). Labour market mismatch among UK graduates: An analysis using REFLEX data. Economics of Education Review, 30(1), 130-145.

McGuinness, S., Pouliakis, K., \& Redmond, P. (2018). Skills mismatch: Concept, measurement and policy approaches. Journal of Economic Surveys, 32(4), 985-1085.

Michaels, G., Natraj, A., \& Van Reenen, J. (2014). Has ICT polarized skill demand? Evidence from eleven countries over twenty-five years. Review of Economics and Statistics, 96(1), 60-77.

Mincer, J. (1974). Schooling, experience, and earnings. New York, NY: Colombia University Press.

Moher, D., Fortin, P., Jadad, A. R., Jüni, P., Klassen, T., Le Lorier, J., Liberati, A., Penna, A., \& Linde, K. (1996). Completeness of reporting of trials published in languages other than English: Implications for conduct and reporting of systematic reviews. The Lancet, 347(8998), 363-366.

Montenegro, C. E., \& Patrinos, H. A. (2014). Comparable estimates of returns to schooling around the world (World Bank Policy Research Working Paper WPS7020).

Mora, T. (2010). Why do higher graduates regret their field of studies? Some evidence from Catalonia, Spain. Education Economics, 18(1), 93-109.

Moretti, E. (2004). Human capital externalities in cities. In J. V. Henderson \& J. F. Thisse (Eds.), Handbook of Regional and Urban Economics (Vol 4. pp. 2243-2291). Amsterdam, The Netherlands: Elsevier.

Muysken, J., Kiiver, H., \& Hoppe, M. M. (2003). The impact of education and mismatch on wages: Germany, 1984-2000. In F. Büchel, A. De Grip \& A. Mertens (Eds.), Overeducation in Europe: Current Issues in Theory and Policy (pp. 109-132). Cheltenham, UK: Edward Elgar Publishing.

Nair, C. S., Patil, A., \& Mertova, P. (2009). Re-engineering graduate skills: A case study. European Journal of Engineering Education, 34(2), 131-139.

Nickell, S. J. (1978). Fixed costs, employment and labour demand over the cycle. Economica, 45(180), 329-45.

Nieto, S., Matano, A., \& Ramos, R. (2015). Educational mismatches in the EU: Immigrants vs natives. International Journal of Manpower, 36(4), 540-561. 
Nordhaus, W. D. (2007). Two centuries of productivity growth in computing. The Journal of Economic History, 67(1), 128-159.

Nordin, M., Persson, I., \& Rooth, D. (2010). Education-occupation mismatch: Is there an income penalty? Economics of Education Review, 29(6), 1047-1059.

Nugent, G., Barker, B., Grandgenett, N., \& Adamchuk, V. I. (2010). Impact of robotics and geospatial technology interventions on youth STEM learning and attitudes. Journal of Research on Technology in Education, 42(4), 391-408.

O’Brien, V., Martinez-Pons, M., \& Kopala, M. (1999). Mathematics self-efficacy, ethnic identity, gender, and career interests related to mathematics and science. Journal of Educational Research, 92(4), 231-235.

OECD (2014). Education at a glance 2014: OECD indicators. Paris, France: OECD Publishing.

OECD (2017). OECD skills strategy diagnostic report: The Netherlands 2017. Paris, France: OECD Publishing.

Ommeren, van J. N., Rietveld, P., \& Nijkamp, P. (1998). Spatial moving behavior of twoearner households. Journal of Regional Science, 38(1), 23-41.

Oreopoulos, P., \& Dunn, R. (2013). Information and college access: Evidence from a randomized field experiment. The Scandinavian Journal of Economics, 115(1), 3-26.

Ours, van J., \& G. Ridder. (1992). Vacancies and the recruitment of new employees. Journal of Labor Economics, 10(2), 138-55.

Pekkala Kerr, S., Pekkarinen, T., Sarvimäki, M., \& Uusitalo, R. (2015). Post-secondary education and information on labor market prospects: A randomized field experiment (IZA Discussion Paper No. 9372).

Pellizari, M., \& Fichen, A. (2013). A new measure of skills mismatch (OECD Social, Employment and Migration Working Papers No. 153). Paris, France: OECD Publishing.

Pissarides, C. A. (2000). Equilibrium unemployment theory (2 ${ }^{\text {nd }}$ ed). Cambridge, MA: MIT Press.

Pistolesi, N. (2017). Advising students on their field-of-study: Evidence from a French university reform. Labour Economics, 44, 106-121. 
Psacharopoulos, G., \& Patrinos, H. A. (2004). Returns to investment in education: A further update. Education Economics, 12(2), 111-134.

Quintano, C., Castellano, R., \& D'Agostino, A. (2008). Graduates in economics and educational mismatch: The case study of the University of Naples 'Parthenope'. Journal of Education and Work, 21(3), 249-271.

Quintini, G. (2011a). Over-qualified or under-skilled: A review of existing literature (OECD Social, Employment and Migration Working Papers No. 121). Paris, France: OECD Publishing.

Quintini, G. (2011b). Right for the job: Over-qualified or under-skilled? (OECD Social, Employment and Migration Working Papers No. 120). Paris, France: OECD Publishing.

Radner, R. (1993). The organization of decentralized information processing. Econometrica: Journal of the Econometric Society, 61(5), 1109-1146.

Rauch, J. E. (1993). Productivity gains from geographic concentration of human capital: Evidence from the cities. Journal of Urban Economics, 34(3), 380-400.

Reuben, E., Wiswall, M., \& Zafar, B. (2017). Preferences and biases in educational choices and labour market expectations: Shrinking the black box of gender. The Economic Journal, 127(604), 2153-2186.

ROA (2017a). De arbeidsmarkt naar opleiding en beroep tot 2022 (ROA Reports No. 010). Maastricht, The Netherlands: Research Centre for Education and the Labour Market.

ROA. (2017b). Schoolverlaters tussen onderwijs en arbeidsmarkt 2016 (ROA Reports No. 007). Maastricht, The Netherlands: Research Centre for Education and the Labour Market.

Robert, P. (2014). Job mismatch in early career of graduates under post-communism. International Journal of Manpower, 35(4), 500-513.

Robst, J. (2007a). Education and job match: The relatedness of college major and work. Economics of Education Review, 26(4), 397-407.

Robst, J. (2007b). Education, college major, and job match: Gender differences in reasons for mismatch. Education Economics, 15(2), 159-175. 
Robst, J. (2008) Overeducation and college major: Expanding the definition of mismatch between schooling and jobs. The Manchester School, 76(4), 349-368.

Roe, R. A. (2002). Competences - A Key towards the integration of theory and practice in work and organizational psychology. Gedrag en Organisatie, 15(4), 203-224.

Roese, N. J., \& Summerville, A. (2005). What we regret most ... and why. Personality and Social Psychology Bulletin, 31(9), 1273-1285.

Rogerson, R., Shimer, R., \& Wright, R. (2005). Search-theoretic models of the labor market: A survey. Journal of Economic Literature, 43(4), 959-988.

Rosenzweig, E. Q., \& Wigfield, A. (2016). STEM motivation interventions for adolescents: A promising start, but further to go. Educational Psychologist, 51(2), 146163.

Rubb, S. (2003). Overeducation in the labor market: A comment and re-analysis of a meta-analysis. Economics of Education Review, 22(6), 621-629.

Rumberger, R. (1987). The impact of surplus schooling on productivity and earnings. Journal of Human Resources, 22(1), 24-50.

Rumberger, R. W. (1987). The impact of surplus schooling on productivity and earnings. Journal of Human Resources, 22(1), 24-50.

Sánchez-Sánchez, N., \& McGuinness, S. (2015). Decomposing the impacts of overeducation and overskilling on earnings and job satisfaction: An analysis using REFLEX data. Education Economics, 23(4), 419-432.

Scherer, K. R., Wallbott, H. G., \& Summerfield, A. B. (1986). Experiencing emotion: A cross cultural study. Cambridge, UK: Cambridge University Press.

Sellami, S., Verhaest, D., \& Van Trier, W. (2018). How to measure field-of-study mismatch? A comparative analysis of the different methods. LABOUR, 32(4), 141-173.

Shavit, Y., \& Muller, W. (2000). Vocational secondary education. European Societies, 2(1), 29-50.

Shevchuk, A., Strebkov, D., \& Davis, S. N. (2015). Educational mismatch, gender, and satisfaction in self-employment: The case of Russian-language internet freelancers. Research in Social Stratification and Mobility, 40, 16-28. 
Sicherman, N. (1991). "Overeducation" in the labor market. Journal of Labor Economics, 9(2), 101-122.

Simon, H.A. (1955). A behavioral model of rational choice. The Quarterly Journal of Economics, 69(1), 99-118.

Siow, A. (1984). Occupational choice under uncertainty. Econometrica, 52(3), 631-645.

Sloane, P. J. (2003). Much ado about nothing? What does the overeducation literature really tell us. In F. Büchel, A. De Grip \& A. Mertens (Eds.), Overeducation in Europe. Current Issues in Theory and Policy (pp. 11-45). Cheltenham, UK: Edward Elgar Publishing.

Spence, M. (1973). Job Market Signalling. The Quarterly Journal of Economics, 87(3), 355-374.

Spitz-Oener, A. (2006). Technical change, job tasks, and rising educational demands: Looking outside the wage structure. Journal of Labor Economics, 24(2), 235-270.

Statistics Netherlands (2018). Leerlingen, deelnemers en studenten; onderwijssoort, vanaf 1900. Retrieved from: http:/ / statline.cbs.nl/Statweb/publication/?DM=SLNL\&PA=37220\&D1=73\& $\mathrm{D} 2=1-2 \& D 3=102-114 \& H D R=\mathrm{G} 1, \mathrm{~T} \& \mathrm{STB}=\mathrm{G} 2 \& \mathrm{VW}=\mathrm{T}$

Statistics Netherlands (2019a, June 30). Statistics Netherlands: Arbeidsdeelname en werkloosheid per maand (12-uursgrens). Retrieved from: https://opendata.cbs.nl/statline/\#/CBS/nl/dataset/80479ned/table?ts=1561886 372101

Statistics Netherlands (2019b, June 30). Statistics Netherlands: Gediplomeerden en afgestudeerden; onderwijssoort; vanaf $1900 . \quad$ Retrieved from: https://opendata.cbs.nl/statline/\#/CBS/nl/dataset/80384ned/table?ts=1561887 591632

Statistics Netherlands (2019c, June 30). Statistics Netherlands: Spanning arbeidsmarkt naar nieuw hoogtepunt. Retrieved from: https://www.cbs.nl/nl$\mathrm{nl} /$ nieuws/2019/07/spanning-arbeidsmarkt-naar-nieuw-hoogtepunt

Statistics Netherlands (2019d, June 30). Statistics Netherlands: Vacatures; seizoensgecorrigeerd; SBI 2008. Retrieved from: https://opendata.cbs.nl/statline/\#/CBS/nl/dataset/80474ned/table?ts=1561883 601999 
Stigler, G. J. (1962). Information in the labor market. Journal of Political Economy, 70(5), 94105.

Thurow, L. (1975). Generating Inequality. New York, NY: Basic Books.

Tilak, J. B. (2008). Higher education: A public good or a commodity for trade? Prospects, 38(4), 449-66.

Tsang, M. (1987). The impact of underutilization of education on productivity: A case study of the U.S. bell companies. Economics of Education Review, 6(3), 239-54.

Tsang, M. C., \& Rumberger, R. W., \& Levin, H. M. (1991). The impact of surplus schooling on worker productivity. Industrial Relations, 30(2), 209-28.

Turner, T., \& Niemeier. D. (1997). Travel to work and household responsibility: New evidence. Transportation, 24(4), 397-419.

Tversky, A., \& Kahneman, D. (1974). Judgment under uncertainty: Heuristics and biases. Science, 185(4157), 1124-1131.

Velden, Van der R., \& Bijlsma, I. (2018). Effective skill: A new theoretical perspective on the relation between skills, skill use, mismatches, and wages. Oxford Economic Papers, 71(1) 145-165.

Verdugo, R. R., \& Verdugo, N. (1989). The impact of surplus schooling on earnings: Some additional findings. Journal of Human Resources, 24(4), 629-643.

Verhaest, D., \& Omey, E. (2006). The impact of overeducation and its measurement. Social Indicators Research, 77(3), 419-448.

Verhaest, D., \& Omey, E. (2009). Objective over-education and worker well-being: A shadow price approach. Journal of Economic Psychology, 30(3), 469-81.

Verhaest, D., Sellami, S., Van der Velden, R. (2017). Differences in horizontal and vertical mismatches across countries and fields of study. International Labour Review, 156(1), 1-23.

Verick, S. (2009). Who is hit hardest during a financial crisis? The vulnerability of young men and women to unemployment in an economic downturn (IZA Discussion Paper No. 4359).

Vrontis, D., Thrassou, A., \& Melanthiou, Y. (2007). A contemporary higher education student-choice model for developed countries. Journal of Business Research, 60(9), 979-989. 
Webbink, D., \& Hartog, J. (2004). Can students predict starting salaries? Yes! Economics of Education Review, 23(2), 103-113.

Weinberger, C. J. (2014). The increasing complementarity between cognitive and social skills. Review of Economics and Statistics, 96(4), 849-861.

Weiss, Y. (1971). Investment in Graduate Education. The American Economic Review, 61(5), 833-852. Retrieved from http://www.jstor.org/stable/1813145

Weiss, Y. (1972). The risk element in occupational and educational choices. Journal of Political Economy, 80(6), 1203-13.

Welch, A. G. (2010). Using the TOSRA to assess high school students' attitudes toward science after competing in the FIRST robotics competition: An exploratory study. Eurasia Journal of Mathematics, Science \& Technology Education, 6(3), 187-197.

Werfhorst, van de H. G. (2002). Fields of study, acquired skills and the wage benefit from a matching job. Acta Sociologica, 45(4), 286-303.

Wise, D. A. (1975). Academic achievement and job performance. The American Economic Review, 65(3), 350-366. Retrieved from http://www.jstor.org/stable/1804839

Wiswall, M., \& Zafar, B. (2015a). Determinants of college major choice: Identification using an information experiment. Review of Economic Studies, 82(2), 791-824.

Wiswall, M., \& Zafar, B. (2015b). How do college students respond to public information about earnings? Journal of Human Capital, 9(2), 117-169.

Witte, J. C., \& Kalleberg, A. L. (1995). Matching training and jobs: The fit between vocational education and employment in the German labour market. European Sociological Review, 11(3), 293-317.

Wolbers, M. H. J. (2003). Job mismatches and their labour-market effects among schoolleavers in Europe. European Sociological Review, 19(3), 249-266.

Woods, F., \& O'Leary, C. (2006). Conceptual framework for an optimal labour market information system (Upjohn Institute Technical Report No. 07-022). Kalamazoo, MI: Upjohn Institute for Employment Research.

Wyss, V. L., Heulskamp, D., \& Siebert, C. J. (2012). Increasing middle school student interest in STEM careers with videos of scientists. International Journal of Environmental and Science Education, 7(4), 501-522. 
Xia, X. (2016). Forming wage expectations through learning: Evidence from college major choices. Journal of Economic Behavior \& Organization, 132, 176-196.

Yakusheva, O. (2010). Return to college education revisited: Is relevance relevant? Economics of Education Review, 29(6), 1125-1142.

Zafar, B. (2011). How do college students form expectations? Journal of Labor Economics, 29(2), 117- 169.

Zafar, B. (2011). How do college students form expectations? Journal of Labor Economics, 29(2), 301- 348.

Zafar, B. (2013). College major choice and the gender gap. Journal of Human Resources, $48(3), 545-595$.

Zarkin, G. A. (1985). Occupational choice: An application to the market for public school teachers. The Quarterly Journal of Economics, 100(2), 409-446.

Zeelenberg, M. (1999). The use of crying over spilled milk: A note on the rationality and functionality of regret. Philosophical Psychology, 12(3), 325-340.

Zhu, R. (2014). The impact of major-job mismatch on college graduates' early career earnings: Evidence from China. Education Economics, 22(5), 511-528. 




\section{Valorisation Addendum}




\section{Valorisation addendum}

Matching the skill supply to the demand for skills in the labour market is of utmost importance for workers, firms, and the economy in general. A situation in which the match between the supply and demand for labour does not come about well is also referred to as skill mismatch. A poor match between workers and jobs is often associated with undesirable outcomes. Mismatched workers generally incur a wage penalty, are less satisfied with their jobs, experience more health issues, and face an increased risk of long unemployment spells. From a societal perspective, the development of human capital can be considered an expensive outlay that is made through public investment in education and training. Skill mismatch can result in lower returns on public investment, not only in the form of foregone tax revenues but also in terms of increased spending on unemployment allowances. The highest return on human capital investments is realised when workers are properly matched to jobs, such that the skills acquired through education and on-the-job training can be optimally utilized in the labour market. Matching skills to jobs is gaining importance in the context of increased global competition, accelerated pace of technological change, and changes in the qualification level of the labour force. With this dissertation, I seek to provide insight into the extent to which skill mismatch is present in the labour market - in particular the Dutch labour market - and what policy measures can be deployed to prevent mismatch. Moreover, I aim to shed light on how the demand for skills is changing. The findings of this dissertation are particularly valuable in shaping education and training policies and in aiding individuals in making human capital investment decisions.

In Chapter 3, I examine how the pervasiveness of skill mismatch in the Dutch labour market has developed over the past decades from the perspective of employers. Specifically, I examine to what extent firms face skill gaps by exploiting survey data on whether their workforces are equipped to perform their job tasks in the coming years. I document how the incidence of skill mismatch has developed over the period 1991-2011 and whether the observed trend can be explained by the educational upgrading of the Dutch workforce. During this period, the educational attainment of the workforce increased at all levels. The educational expansion coincided with a significant increase in public investments in education. While an extensive literature exists on the education expansion and its implications for workers, it remains unclear whether firms have benefitted from the increased educational attainment of the labour force. I illustrate that in 1991, almost half of the Dutch employers reported that their workforce is not sufficiently equipped to perform the job tasks, while in 2011, only a quarter of the employers reported skill mismatch. The educational upgrading of the labour force significantly contributed to this declining mismatch trend. 
Given that the Dutch higher education premium has continued to increase since the early nineties, our results suggest that the supply of higher skilled graduates has responded positively to the increasing demand for skilled labour. Nevertheless, the findings of Chapter 3 do not imply that policies should simply be geared toward increasing the educational attainment of the labour force. Despite the increasing college premium, there is ample evidence that the educational expansion has forced many job seekers to accept jobs below their level of education. These developments indicate that the premium on higher education is not incurred by every college or university graduate. In fact, the labour market returns across college majors are heterogeneous. Moreover, the wage dispersion among workers with similar levels of schooling has increased in recent decades, at least in other developed economies. This informs us that the type of skills that students acquire through formal education - in addition to the level of skills - is becoming increasingly important in determining graduates' labour market success. In fact, in Chapter 2, I illustrate that the consequences of a job-education mismatch is more pronounced in situations in which workers' field-specific skills are underutilised. For example, graduates who predominantly acquired occupation-specific skills suffer from larger wage penalties when they end up in a job that is unrelated to their field-of-study than workers who mainly possess general skills that can be applied in a wider variety of jobs.

The increasing importance of acquiring specific type of skills - rather than just investing in additional years of schooling - is also illustrated well in Chapter 6. In this chapter, I examine how different types of skills are rewarded in the Dutch labour market and how this has changed over the past two decades. Specifically, I investigate how the labour market reward for non-routine skills have changed between 2001 and 2016. I document that the return to analytical skills has substantially increased over this period of time. This not only holds true for workers in the upper-end of the wage distribution, but also for workers in the middle- and lower-end of the distribution. A potential explanation for this findings is that the demand for non-routine tasks (i.e. interpreting and analysing information) has increased as computerization has improved the productivity and lowered the price of tasks (i.e. retrieving and manipulating information) that typically complement non-routine tasks. While certain tasks in many middle-skill occupations are susceptible to automation, the increasing return for non-routine tasks across all segments of the wage distribution points out that many jobs will continue to require a changing set of skills. Hence, encouraging the development of analytical skills will not only continue to be essential in higher education, but also in other segments of the education system.

In Chapter 4, I investigate whether a five-day study choice intervention that is offered to 16-year olds can motivate students in pre-vocational education (pre-VET or in Dutch: 
vmbo) to choose for a Science, Technology, Engineering and Mathematics (STEM) programme in upper-secondary vocational education and training (VET or in Dutch: mbo). The demand for VET graduates with a STEM degree is increasing in the Dutch labour market and is expected to grow further in the future. Despite the rising demand for STEM workers, the share of VET graduates with a STEM degree has declined in recent years. This chapter aims to shed light on how skill shortages can be prevented in the Dutch labour market. STEM education in VET prepares students for a wide range of occupations (e.g. construction workers, electricians, mechanical technicians, maintenance and repair workers) and constitutes an important supply source for STEM-related skills. By letting students engage in hands-on activities, the five-day intervention introduced pre-VET students to a number of STEM occupations. In addition, participating students were informed about the labour market perspectives of each of these education programmes.

While the intervention did not increase STEM enrolment among native Dutch students, it did have a small positive effect on immigrant background students. The latter group tends to be less confident about its ability to successfully complete a STEM programme, is on average less well-informed about the labour market perspectives of different schooling paths, and has more negative associations with STEM jobs due to the low status in the country of origin (e.g. construction work). Hence, the information deficiency regarding students own ability, preferences, and the labour market is likely to be greater for immigrant students. Consequently, the potential of the intervention to reduce this information gap was greater for immigrant students. The intervention most likely only had a small to no effect due to the selective sample of participants. The majority of students participating in the intervention already showed a clear interest in a STEM career and most likely would have enrolled in a STEM programme even in absence of the intervention. Provided that pre-VET students are already tracked into different sectors (e.g. health, agriculture or STEM) at the age of 14, students should be targeted by STEM interventions at an earlier stage in their educational trajectory. Moreover, prior research has shown that many graduates with a STEM degree still end up in unrelated jobs. As such, future policy interventions should not only encourage students to choose for STEM education, but actually ensure that graduates exploit their STEM skills in the labour market. More research is needed to show how this can be achieved.

In Chapter 5, I explore how the quality of educational choices can be improved to prevent skill mismatch. In the Netherlands, there is growing attention for the development of relevant indicators of current and future field-specific labour demand to guide students in their schooling and occupation choices. Such forecasts are particularly relevant for vocational programmes as these tracks are more sensitive to fluctuations in the labour 
market. Given that I cannot directly test whether increasing the availability of labour market information affects youngsters' field-of-study choice, I examine how unanticipated changes in labour market conditions are related to the quality of educational choices. The quality of schooling choices is measured by whether graduates experience regret in their field-of-study choice upon labour market entry. The findings of my study indicate that graduates are more likely to regret their field-of-study choice when they experience unfavourable changes in labour market conditions. This relationship is only observed for male graduates which could be explained by the fact that males and females form their education choices on different grounds, males attaching more weight to pecuniary aspects of their future job than do females. Another potential reason for this gender difference is that females sort into fields (e.g. healthcare) that are more stable across business cycles. From a policy perspective, the findings suggest that prospective VET students could benefit from improved availability of accurate labour market forecasts by field-of-study. Although improving the availability of labour market information is a necessary condition to improve students' educational choices, it remains unclear whether providing students with information alone is sufficient to affect their behaviour. Hence, policy makers should focus attention on helping students to digest and incorporate labour market information into their decision-making process. 



\section{Summary}




\section{Summary}

A good match between the supply of human capital and the demand for labour is indispensable for workers, companies and, consequently, for the economy as a whole. Youngsters invest in their human capital by choosing an educational path based on their talents, preferences and expectations regarding their labour market perspectives. Employers recruit workers based on their competences and business opportunities. Despite the fact that the match between the demand and supply of human capital often turns out well, attention is often focused on situations in which an adequate match is not realised. Such a situation is typically referred to as a mismatch between education (or skill) supply and education (or skill) demand in the labour market.

For the individual, skill mismatch can lead to an increased risk in long unemployment spells, wage penalties, job dissatisfaction, and health issues. Education can be considered an expensive outlay that society makes through public investment in education. The highest return on this investment is realized when individuals are wellmatched to employers, such that the human capital acquired through education and on-the-job training can be optimally utilized in the labour market. Skill mismatch can result in sacrificed returns on public investment in education, not only in the form of tax revenues but also in unemployment allowances.

The prevalence of skill mismatch in the labour market can be considered as the sum of different types of mismatch. The literature distinguishes between at least four types of mismatch: vertical, horizontal intra-curricular, and geographical mismatch. Vertical mismatch implies that the worker's attained level of education is higher or lower than is required for the job. The worker is considered to be over-educated (undereducated) when the acquired level of education is higher (lower) than required for the job. A situation in which the field-of-study does not adequately match the job is referred to as horizontal mismatch. Intra-curricular mismatch occurs when the knowledge and skills that are acquired through formal education do not match the requirements of the job for which graduates have been trained. Finally, geographical mismatch refers to a situation in which the demand and supply for skills reside in different regions.

A substantial amount of research has been conducted on the causes, consequences, and incidence of vertical mismatch. Research shows that over-education is associated with, among other things, wage losses and job dissatisfaction. Despite the fact that workers are not matched to jobs based solely on their level of education, but also their 
field-of-study, horizontal mismatch has received relatively little attention in the literature. Chapter 2 presents a systematic literature review on the determinants, consequences and degree to which horizontal mismatch is present on the international labour market. Compared to workers who are well-matched in terms of their field-ofstudy, horizontally mismatched workers generally incur a wage loss, are less satisfied with their jobs, and are more likely to experience regret in their chosen field-of-study. The consequences associated with horizontal mismatch depend on the extent to which employees possess general skills as opposed to occupation-specific skills. Although graduates who have mainly acquired occupation-specific skills are more likely to end up in jobs for which they have been trained, the wage penalties associated with horizontal mismatch tend to be higher for such graduates, given that their skills are less transferable across occupations. This systematic review also shows that research would benefit from a more uniform definition of horizontal mismatch. Prior research typically refers to horizontal mismatch when the field-of-study is not a requirement for the job. However, a situation in which the field-of-study is not required for the job might only imply that graduates underutilize their skills and knowledge if they have been trained for specific occupations. Graduates who have mainly acquired general skills and knowledge, in contrast, will be able to transfer their human capital to a wider variety of occupations.

Aside from the fact that the literature is primarily focussed on vertical mismatch, most studies use a mismatch indicator that only captures one form of skill mismatch. Chapter 3 uses a mismatch indicator that encompasses all types of skill mismatch derived from surveys that have been disseminated among Dutch employers by the Netherlands Institute for Social Research (SCP). Over the period 1991-2011, employers were asked whether their workforce was adequately equipped to meet the job requirements in the coming years. This indicator is able to capture a poor match between job requirements and employees' human capital within firms that can arise from vertical, horizontal, intra-curricular, and geographic mismatch. While almost half of the employers indicated that their workforce was not sufficiently equipped to meet the job requirements in 1991, by 2011 only a quarter of the employers reported such mismatches. Moreover, while the number of graduates with an upper-secondary degree has increased in the last decades, the share of graduates who enter the labour market without any labour-market qualification has declined substantially. The findings in Chapter 3 show that the trend towards reduced mismatches can be attributed at least partially to higher levels of education in the Dutch labour force, although these trends may also suggest intensification of over-education amongst 
employees during the same period. For employers, however, increased education in the workforce has been beneficial, and there is empirical evidence suggesting that the presence of over-educated workers in a firm increases productivity.

Chapter 4 and Chapter 5 provide insight into which interventions can prevent potential mismatch between human capital and the requirements in the labour market. Chapter 4 evaluates the effectiveness of a five-day intervention that took place in the schoolyear 2014-15 in the Amsterdam Metropolitan Area. The aim of the intervention was to motivate students in the final year of pre-vocational education to choose a STEMrelated study programme in VET. The intervention was designed as a response to a shortage of STEM workers on the regional labour market. During the intervention, students were introduced to a variety of STEM occupations through hands-onactivities and informed about the labour market perspectives associated with different STEM programmes. Using a rich administrative dataset, Chapter 4 shows that participation in the intervention did not increase native students' probability to choose for STEM education. A potential explanation for this finding is that the native Dutch students who participated in the intervention would have enrolled in a STEM education anyway, in absence of the intervention, given that the majority of those participants already followed STEM-related courses. The intervention could potentially motivate more students to choose a STEM field-of-study if it were offered at an earlier stage in the students' educational career.

In contrast, the intervention had a small but positive effect on students with an immigrant background. Gaining hands-on-experience in a variety of STEM occupations might have removed the negative image of these occupations held by immigrant students and provided them with a more realistic perception about their ability to successfully complete a STEM programme. Finally, given that immigrant students tend to suffer from larger information deficiencies regarding the labour market perspectives associated with different fields of study, the intervention might have updated students about the opportunities that STEM programmes offer.

Chapter 5 used an alternative indicator for the match between education and the labour market, namely, regret about the chosen field-of-study. Chapter 5 shows that, at the time of entering the labour market, more than one in four VET graduates indicated that they regretted the field-of-study they had chosen. While field-of-study choice regret has multiple determinants, unanticipated changes in the labour market appears to be an important predictor. The relationship between labour market changes and regret for the field-of-study choice is of particular relevance to VET students, as they 
prepare for specific occupations. Chapter 5 demonstrates that the probability of experiencing regret is strongly related to the discrepancy between the field-specific unemployment rate at the time the course of study was chosen and entry into the labour market. This probability is driven by situations in which labour market conditions at the time of entry are worse than expected. These findings suggest that youngsters could benefit from greater availability of accurate labour market forecasts by field-of-study. Moreover, students could be encouraged to incorporate the available labour market information into their study choice process without disregarding their talents and preferences.

Chapter 6 provides insight into the changing demand for skills on the Dutch labour market. This chapter specifically focuses on the improving reward for non-routine skills. A distinction is made between non-routine analytical skills and non-routine interpersonal skills. The results show that the reward for workers employed in occupations requiring a high level of analytical skills has substantially increased between 2001 and 2016. This holds true for employees in the upper-end and middlesegments as well as lower-end of the wage distribution. This trend suggests that the Dutch labour market not only increasingly rewards analytical skills among highly skilled workers, but also among workers in the middle and lower-ends of the skill distribution. These findings are consistent with the idea that improvements in computer technology complement the skills required to perform non-routine tasks. Technological developments have also reduced communication costs within organisations and encouraged decentralisation of organizational structures. Based on these changes, we can expect employers to place greater demands on workers with a high level of interpersonal and managerial skills. The findings indeed show that, at least for full-time workers in the upper-end of the wage distribution, the premium for interpersonal skills rose between 2001 and 2016. 

Samenvatting 


\section{Samenvatting}

Een goede aansluiting tussen het aanbod van menselijk kapitaal en de vraag vanuit de arbeidsmarkt is essentieel voor een goed functionerende economie en daarmee voor bedrijven en schoolverlaters. Jongeren investeren in hun menselijk kapitaal door een opleiding te kiezen op basis van hun talenten, voorkeuren en perceptie over hun kansen op de arbeidsmarkt. Werkgevers rekruteren werknemers op basis van hun competenties en de ondernemerskansen die zij zien. Ondanks dat deze match van vraag naar en aanbod van menselijk kapitaal vaak goed tot stand komt, gaat de aandacht veelal uit naar situaties waarin deze match niet tot stand komt. Er wordt dan ook wel verwezen naar 'mismatch' tussen onderwijs en arbeidsmarkt.

Een slechte aansluiting tussen onderwijs en arbeidsmarkt kan zowel voor het individu als de maatschappij nadelige gevolgen hebben. De wetenschappelijke literatuur laat zien dat mismatch kan leiden tot hogere risico's op langdurige werkloosheid, loonverlies, baanontevredenheid, en gezondheidsproblemen. Onderwijs wordt in hoge mate uit publieke middelen bekostigd. Het loonverlies dat gepaard gaat met een onderbenutting van menselijk kapitaal resulteert in lagere belastingopbrengsten. Tevens kan mismatch resulteren in een toename van maatschappelijke uitgaven aan WW-uitkeringen, sociale bijstand en zorgkosten als gevolg van een stijgend risico op werkloosheid en gezondheidsproblemen.

De prevalentie van mismatch op de arbeidsmarkt kan in essentie worden beschouwd als de optelsom van verschillende soorten mismatch. De wetenschappelijke literatuur maakt onderscheid tussen ten minste drie vormen van mismatch; verticale, horizontale en intracurriculaire mismatch en geografische mismatch. Verticale mismatch houdt in dat het behaalde opleidingsniveau van de werknemer te hoog of te laag is voor de vereisten die de baan stelt. Men spreekt in het eerste geval van overscholing, in het tweede geval van een scholingstekort. Indien de gevolgde opleidingsrichting niet aansluit bij de baan wordt er gesproken van horizontale mismatch. Intra-curriculaire mismatch komt tot stand wanneer de kennis en vaardigheden die zijn verworven in het initiële onderwijs niet (langer) aansluiten bij de vereisten die het werk stelt waarvoor men is opgeleid. Tot slot spreekt men van geografische mismatch wanneer werknemers met specifieke kennis en vaardigheden in een andere regio wonen dan daar waar de vraag naar deze kennis en vaardigheden hoog is. Bijgevolg kunnen vacatures op de regionale arbeidsmarkt open blijven staan, terwijl het aanbod er op landelijk niveau tegelijkertijd wel is.

Naar de oorzaken, gevolgen, en het bestaan van verticale mismatch binnen en buiten Nederland is het nodige onderzoek gedaan. Uit dit onderzoek komt duidelijk naar voren dat overscholing geassocieerd wordt met loonverlies en minder baantevredenheid. 
Ondanks dat een goede aansluiting tussen onderwijs en de baan niet alleen bepaald wordt door het opleidingsniveau, maar ook door de gevolgde opleidingsrichting, is er in de wetenschappelijke literatuur minder aandacht geweest voor horizontale mismatch. In Hoofdstuk 2 wordt een systematische literatuurstudie besproken naar de oorzaken, gevolgen en mate waarin horizontale mismatch voorkomt. Werknemers die zich in een baan bevinden die niet aansluit bij de gevolgde opleidingsrichting ervaren over het algemeen loonverlies, zijn minder tevreden met de baan, en hebben een grotere kans om spijt te hebben van de gevolgde opleidingsrichting. De gevolgen die gepaard gaan met horizontale mismatch hangen af van de mate waarin werknemers over algemene of beroepsspecifieke vaardigheden beschikken. $\mathrm{Zo}$ is het loonverlies als gevolg van horizontale mismatch minder groot indien werknemers overwegend over algemene vaardigheden beschikken die breed inzetbaar zijn. Uit de systematische literatuurstudie komt tevens naar voren dat onderzoek naar horizontale mismatch baat zou hebben bij een uniformere definitie van deze mismatchvorm. Zo spreekt men in de huidige literatuur van horizontale mismatch indien de gevolgde opleidingsrichting niet vereist was voor het werk waarin de schoolverlater zich bevindt. Een dergelijke situatie duidt echter niet per definitie op een onderbenutting van kennis en vaardigheden. Een onderbenutting van menselijk kapitaal zal zich eerder voordoen indien schoolverlaters met een beroepsspecifieke opleiding in een baan terecht komen waarvoor zij niet zijn opgeleid. Hun kennis en vaardigheden kunnen immers maar binnen een beperkt aantal beroepen worden ingezet. Schoolverlaters die overwegend over generieke kennis en vaardigheden beschikken zullen daarentegen in staat zijn om hun menselijk kapitaal in een breder scala aan beroepen in te zetten.

Naast dat er in de voorgaande wetenschappelijke literatuur een sterke nadruk ligt op verticale mismatch, zijn er tot op heden weinig wetenschappelijke studies beschikbaar die de optelsom maken van de verschillende vormen waarin mismatch zich kan manifesteren. Nochtans is kennis over deze optelsom belangrijk om in te kunnen schatten hoe alomtegenwoordig mismatch tussen onderwijs en arbeidsmarkt is. In Hoofdstuk 3 wordt er gebruik gemaakt van historische cijfers die zijn verzameld door middel van vragenlijsten om de prevalentie van mismatch in Nederland over de tijd in kaart te brengen. In de vragenlijsten die in de periode 1991-2011 zijn uitgezet door het Sociaal en Cultureel Planbureau, worden werkgevers gevraagd of het werknemersbestand voldoende is toegerust voor de eisen die het werk stelt in de komende jaren. Het perspectief van de werkgever over mismatch binnen de organisatie kan als een goede benadering worden beschouwd voor het landelijk voorkomen van mismatch. Indien het personeel onvoldoende is toegerust kan men stellen dat dit het resultaat is van verticale-, horizontale-, intra-curriculaire of geografische mismatch. De vraag houdt ook rekening 
met de uitdagingen waar het bedrijf voor staat, mede bepaald door de tijdsgeest, de economische conjunctuur, regionale, landelijke en internationale ontwikkelingen in beleid, de organisatie van de arbeidsmarkt, en of het personeelsbestand gegeven hun competenties deze uitdagingen tegemoet kan komen.

Hoewel in 1991 nog bijna de helft van de werkgevers aangaf dat het werknemersbestand onvoldoende toegerust is voor de eisen die het werk stelt, ging in 2011 nog maar een kwart van de werkgevers akkoord met deze stelling. Het aantal jongeren dat een havo of vwo diploma behaalt en vervolgens deelneemt aan het onderwijs is in Nederland sterk toegenomen in de afgelopen decennia. Daarnaast is het aantal jongeren dat het onderwijs verlaat zonder startkwalificatie (minimaal havo, vwo of mbo 2 niveau) aanzienlijk afgenomen in de afgelopen twee decennia. Deze studie is ingegaan op de vraag of werkgevers baat hebben gehad bij de afname van voortijdig schoolverlaters en de toegenomen participatie in het hoger onderwijs. De bevindingen van deze studie laten zien dat de gedaalde mismatchtrend in ieder geval deels kan worden verklaard door het gestegen opleidingsniveau van de Nederlandse beroepsbevolking. Hoewel de resultaten aantonen dat het gestegen opleidingsniveau positieve implicaties hebben gehad voor de werkgever, sluiten deze ontwikkelingen niet uit dat er sprake is van een toenemende mate van overscholing op de arbeidsmarkt. Zo blijkt uit eerder onderzoek dat werkgevers een prikkel kunnen hebben om overgekwalificeerde werknemers te werven omdat zij de productiviteit tegen lagere kosten zouden kunnen verhogen.

Hoofdstuk 4 en Hoofdstuk 5 bieden meer inzicht in welke interventies potentieel ingezet kunnen worden om mismatch tussen de aansluiting van menselijk kapitaal en de behoeften op de arbeidsmarkt te voorkomen. In Hoofdstuk 4 wordt de effectiviteit van een vijfdaagse interventie onderzocht die plaatsvond in het schooljaar 2014-15 in de Metropoolregio Amsterdam. Het doel van de interventie was om meer vmboeindexamenleerlingen voor een vervolgopleiding in de techniek te laten kiezen in het mbo. Hiermee werd beoogd om het tekort aan goed geschoold personeel in de technieksector op de regionale arbeidsmarkt aan te pakken. Tijdens de interventie makkten jongeren kennis met diverse beroepen in de techniek door middel van praktijkopdrachten en werden zij geïnformeerd over de perspectieven van techniekopleidingen op de arbeidsmarkt. De onderzoeksresultaten laten zien dat deelname aan de interventie de kans om door te stromen naar een techniekopleiding niet verhoogde voor autochtone leerlingen. Mogelijk kan dit verklaard worden doordat de jongeren die deelnamen aan deze interventie ook in afwezigheid van de interventie voor een opleiding in de techniek zouden kiezen. Het merendeel van de deelnemers volgde immers al techniek-gerelateerde vakken in het vmbo. Idealiter zou de interventie in de 
toekomst in een vroeger stadium worden aangeboden aan jongeren die nog geen duidelijke interesse tonen in het volgen van een techniekopleiding.

De interventie blijkt daarentegen een klein maar positief effect te hebben gehad op jongeren met een migrantenachtergrond. Dit resultaat kan mogelijk verklaard worden doordat migrantenjongeren doorgaans een negatiever beeld hebben van beroepen in de techniek en minder vertrouwen hebben in het succesvol kunnen afronden van een techniek opleiding. Het opdoen van praktijkervaring kan het beeld dat migrantenjongeren hebben van beroepen in de techniek en hun perceptie ten aanzien van hun eigen competenties hebben bijgesteld. Daarnaast zijn migrantenjongeren gemiddeld genomen minder goed geïnformeerd over de perspectieven die verschillende opleidingen bieden op de arbeidsmarkt. Een andere mogelijke verklaring voor het positieve effect onder deze groep jongeren is dat de arbeidsmarktinformatie die tijdens de interventie werd geboden het informatiegebrek onder migrantenjongeren heeft weggenomen.

Hoofdstuk, 5 hanteert een alternatieve indicator voor de aansluiting tussen de gevolgde opleiding en de arbeidsmarkt, namelijk, spijt van de gemaakte studiekeuze. De studie die in dit hoofdstuk wordt besproken laat zien dat meer dan één op de vier jongeren die het middelbaar beroepsonderwijs verlaat aangeeft een andere opleiding te hebben gekozen als zij opnieuw mochten kiezen. Hoewel meerdere oorzaken ten grondslag kunnen liggen aan spijt van de gemaakte studiekeuze, blijken niet-geanticipeerde veranderingen op de arbeidsmarkt een belangrijke voorspeller te zijn van het ervaren van spijt. De relatie tussen veranderende arbeidsmarktomstandigheden en spijt van de gemaakte studiekeuze is in het bijzonder relevant voor studenten in het middelbaar beroepsonderwijs omdat zij voor specifieke beroepsgroepen worden opgeleid. Het onderzoek laat zien dat een discrepantie tussen het werkloosheidscijfer voor de specifieke opleidingsrichting op het moment van de studiekeuze en het werkloosheidscijfer op het moment van arbeidsmarktbetreding sterk gerelateerd is aan het ervaren van spijt. De kans op spijt wordt enkel beïnvloed indien de arbeidsmarktomstandigheden op het moment van arbeidsmarktbetreding minder gunstig zijn dan op het moment van de studiekeuze werd verwacht. Deze inzichten wijzen erop dat jongeren baat zouden kunnen hebben bij het beter beschikbaar stellen van accurate arbeidsmarktprognoses. Daarnaast zouden jongeren aangemoedigd kunnen worden om de beschikbare arbeidsmarktinformatie daadwerkelijk mee te nemen in het studiekeuzeproces zonder aandacht te verliezen voor hun interesses en competenties.

Hoofdstuk 6 biedt inzicht in de veranderende vraag naar vaardigheden op de Nederlandse arbeidsmarkt. In het specifiek kijkt dit hoofdstuk naar de (veranderde) beloning voor niet-routinematige vaardigheden. Hierbij wordt onderscheid gemaakt tussen niet- 
routinematige analytische vaardigheden en niet-routinematige interpersoonlijke managementvaardigheden. De resultaten laten zien dat de beloning voor individuen die werkzaam zijn in beroepen die een hoog niveau van analytische vaardigheden vereisen substantieel is gestegen tussen 2001-2016. Dit geldt voor zowel werknemers in hoogbetaalde, middenbetaalde als laagbetaalde beroepen. Deze trend suggereert dat de vraag naar analytische vaardigheden niet alleen onder hooggeschoolde werknemers is toegenomen op de Nederlandse arbeidsmarkt, maar ook onder middelbaar en laaggeschoolde werknemers. De bevindingen zijn in overeenstemming met het idee dat de verbetering in computertechnologieën complementair zijn aan de vaardigheden die vereist zijn voor het uitvoeren van niet-routinematige taken. Technologische ontwikkelingen hebben tevens de communicatiekosten binnen organisaties gereduceerd en een decentralisatie van organisatiestructuren teweeggebracht. Op basis van deze veranderingen zouden we een toenemende vraag communicatieve en interpersoonlijke managementvaardigheden kunnen verwachten. De bevindingen laten inderdaad zien dat de beloning voor interpersoonlijke managementvaardigheden in ieder geval voor voltijds werkenden is gestegen tussen 2001 en 2016. 


\section{About the author}

Melline Somers was born in Eindhoven, the Netherlands, on July 21, 1990. After completing upper-secondary school at the Augustinianum in 2008, she moved to Maastricht to study Economics and Business Economics at Maastricht University. As part of her Bachelor's programme, Melline studied a semester abroad at The University of Rome Tor Vergata. After obtaining her Bachelor's degree in 2012, she participated in the Erasmus for Young Entrepreneurs Programme to support a social enterprise that aims at reintegrating female inmates into society and civil work in the south of Italy, Lecce. In 2013, Melline worked as an intern in a foreign investment textile company in Vientiane, Laos, where she contributed to the professionalization of its human resource systems. After graduating from the Master Programme Management of Learning at Maastricht University in 2014, Melline joined the Top Institute of Evidence Based Education Research at Maastricht university as a Ph.D. candidate. Her work has been published in the Journal of Economic Surveys and in Studies in Higher Education. During her Ph.D., she taught several courses in the Master for Evidence Based Innovation in Teaching (MEBIT). In 2016, Melline paused her PhD programme for a number of months to participate in the 'Nationale DenkTank' with the theme: The Future of Vocational Education. Currently, Melline is a post-doctoral researcher at the Research Centre for Education and the Labour Market (ROA) at Maastricht University. In a project funded by the European Commissions' H2020 framework, Melline studies the relationship between technological change and social inequalities. In addition, as part of an NWO project she conducts research on how the flexibility of education systems affect (social inequality) in educational outcomes from a cross-country perspective. 


\section{TIER Research Series}

I. C. Haelermans (2012). On the productivity and efficiency of education. The role of innovations in Dutch secondary education.

II. L. van Welie (2013). They will get there! Studies on educational performance of immigrant youth in the Netherlands.

III. S. Cabus (2013). An economic perspective on school dropout prevention using microeconometric techniques.

IV. I. Cornelisz (2013). School choice, competition and achievement: Dutch compulsory education.

V. M. Heers (2014). The effectiveness of community schools: Evidence from the Netherlands.

VI. N. Ruijs (2014). Empirical studies in the economics of education.

VII. D. Bartelet (2015). Basic mathematics skills development in children: An evaluative study on cognitive and educational factors.

VIII. I. Rud (2015). The relationship between youth crime and education.

IX. J. Coenen (2016). Teacher characteristics and student performance.

X. D. Hidalgo Saá (2017). Essays in Economics of education and training.

XI. E. Sneyers (2017). What works to improve student success: The effects of academic dismissal policies, student grants, and institutional mergers on student outcomes.

XII. R. Ariës (2018). An evidence-based approach to working-memory-based training in secondary education to improve reasoning test achievements.

XIII. F. H. G. Haan (2018). In pursuit of excellence: Four (natural) experiments in the economics of education.

XIV. M. A. Somers (2020). Human Capital Mismatch in the Labour Market. 